Historic, archived document

Do not assume content reflects current scientific knowledge, policies, or practices. 

L. O. HOWARD, Entomologist and Chief of Bureau.

\section{PAPERS ON DECIDUOÚS FRUIT INSECTS AND INSECTICIDES.}

I. SPRAYING EXPERIMENTS AGAINST THE GRAPE LEAFHOPPER

IN THE LAKE ERIE VALLEY.

By FRED JOHNSON, Agent and Expert.

II. LIFE HISTORY OF THE CODLING MOTH AND ITS CONTROL ON PEARS IN CALIFORNIA.

By S. W. FOSTER, Agent and Expert.

III. VINEYARD SPRAYING EXPERIMENTS AGAINST THE ROSE-CHAFER

IN THE LAKE ERIE VALLEY.

By FRED JOHNSON, Agent and Expert.

IV. THE CALIFORNIA PEACH BORER.

By DUDLEY MOULTON, special Agent.

V. NOTES ON THE PEACH AND PLUM SLUG.

By R. A. CUSHMAN, Agent and Expert.

VI. NOTES ON THE PEACH BUD MITE.

Bg A. L. QUAINTANCE, In Charge of Deciduous Fruit Insect Investigations.

VII. THE GRAPE SCALE.

By JAMES F. ZIMMER, Entomological Assistant.

WASHINGTON:

QOVERNMENT PRINTING OFIIOE.

1912. 



\section{U. S. DEPARTMENT OF AGRICULTURE,}

BUREAU OF ENTOMOLOGY - BULLETIN No. 97.

L. O. HOWARD, Entomologist and Chief of Bureau.

\section{PAPERS ON DECIDUOUS FRUIT INSECTS AND INSECTICIDES.}

I. SPRAYING EXPERINENTS AGAINST THE GRAPE LEAFHOPPER

IN THE LAKE ERIE VALLEY.

By FRED JOHNSON, Agent and Expert.

II. LIFE HISTORY OF THE CODLING MOTH AND ITS CONTROL ON PEARS IN CALIFORNIA.

By S. W. FOSTER, Agent and Expert.

III. VINEYARD SPRAYING EXPERINENTS AGAINST THE ROSE-CHAFER

IN THE LAKE ERIE VALLEY.

By FRED JOHNSON, Agent and Expert.

IV. THE CALIFORNIA PEACH BORER.

By DUDLEY MOULTON, Special Agent.

V. NOTEES ON THE PEACH AND PLUM SLUG.

By R. A. CUSHMAN, Agent and Expert.

VI. NOTES ON THE PEACH BUD MITE.

By A. L. QUAINTANCE, In Charge of Deciduous Fruit Insect Investigations.

VII. THE GRAPE SCALE.

By JAMES F. ZIMMER, Entomological Assistant.

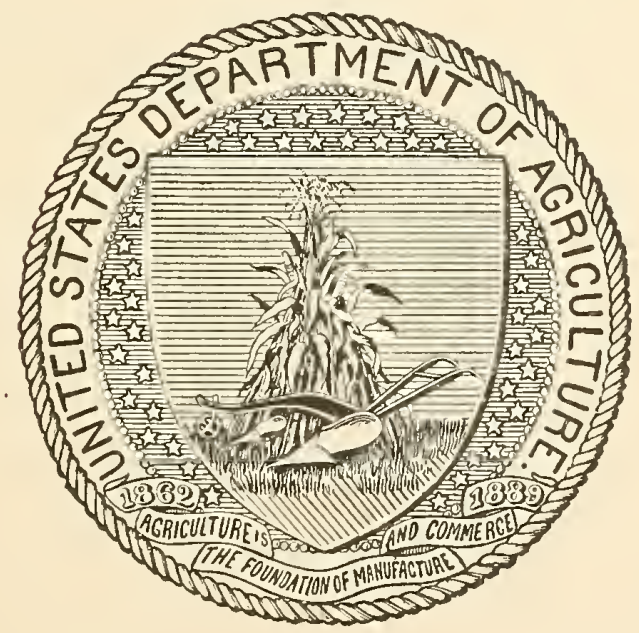

WASHINGTON:

GOVERNMENT PRINTING OFFICE.

1912. 


\section{BLREAU OF ENTOHOLOGY.}

L. O. Howard, Entomologist and Chief of Bureau.

C. L. Marlate, Entomologist and Acting Chief in Absence of Chief.

R. S. Clifton, Executive Assistant.

II. F. Tastet, Chief Clerk.

F. H. Chittendex, in charge of truck crop and stored product insect investigations.

A. D. Hopkins, in charge of forest insect investigations.

II. D. Hunter, in charge of southern field crop insect investigations.

F. M. WEBSTER, in charge of cereal and forage insect investigations.

A. L. QuaINTANCE, in charge of deciduous fruit insect investigations.

E. F. Phillips, in charge of bee culture.

D. M. Rogers, in charge of preventing spread of moths, field work.

Rolla P. CuRrie, in charge of editoria? work.

MaBel Colcond, in charge of library.

\section{Deciduous Fruit Insect Investigations.}

A. L. Quaintance, in charge.

Fred Johnson, S. IT. Foster, ${ }^{1}$ P. R. Jones, ${ }^{1}$ F. E. Brooks, A. G. Hamitar, E. W. Scott, R. I. Nougaret, R. A. Cushman, L. I. Scott, J. B. Gill, A. C. Baker, W. M. Dalidson, E. B. Blakeslee, IT. B. Mood, E. H. Siegler, F. L. SimaxTOx, entomological assistants.

J. F. Zimmer, W. S. Аввотт, W. H. Sill, entomological assistants, employed in enforcement of insecticide act, 1910. 


\section{LETTER OF TRANSUITTAL.}

U. S. Department of Agriculture,

Bureau of Entomology, Washington, D. C., October $26,1912$.

SiR: I have the honor to transmit herewith, for publication as Bulletin No. 97, seven papers dealing with deciduous fruit insects and insecticides. These papers, which were issued separately during 1911-12, are as follows: Spraying Experiments Against the Grape Leafhopper in the Lake Erie Valley, by Fred Johnson; Life History of the Codling Moth and Its Control on Pears in California, by S. W. Foster; Vineyard Spraying Experiments Against the Rose-Chafer in the Lake Erie Valley, by Fred Johnson; The California Peach Borer, by Dudley Moulton; Notes on the Peach and Plum Slug, by R. A. Cushman; Notes on the Peach Bud Mite, by A. L. Quaintance; The Grape Scale, by James F. Zimmer.

Respectfully,

Hon. James Wilson,
L. O. Howard, Entomologist and Chief of Bureau.

Secretary of Agriculture. 



\section{PREFACE.}

The present series of articles on deciduous fruit insects and insecticides, Parts I to VII, comprises Bulletin 97.

The first article deals with the grape leafhopper in the Lake Erie Valley. This insect, always more or less present in vineyards, becomes excessively abundant and destructive during certain years, when its control becomes very essential in the production of grapes of high quality. In this paper report is made on large-scale experiments in vineyards with a nicotine spray directed principally against the insect while in an immature stage. It has been found practicable so to destroy the nymphs of the first brood that the insect is unable, as the season progresses, to attain sufficient numbers to cause important injury.

The second paper is on the life history and control of the codling moth in reference to its occurrence on pears in California and presents results of spraying operations in pear orchards, which show beyond doubt that injuries from this insect on pears may be prevented quite as satisfactorily as in the case of apples. The spraying schedule developed as the result of these experiments has been adopted by a large number of pear growers in California.

The third paper gives results of experiments against the rosechafer as an enemy of grapes in the Lake Erie Valley. This is another insect which periodically causes very serious damage to vineyards, as well as to many other horticultural crops, especially in regions where the soil is sandy. The results, on the whole, do not show the degree of benefit that may be obtained by spraying operations against many other insects; nevertheless they point out the desirability of this work during periods of excessive abundance of the insect.

The fourth paper, dealing with the California peach borer, is the result of observations made on this insect covering a period of two or three years and relates particularly to its life history. The methods of control given, however, are those thought to be best under California conditions.

The fifth paper, on the peach and plum slug, gives the results of observations on the life history and habits made during a period of abundance of this insect in the vicinity of Tallulah, La. The remedial measures suggested, while not actually tested under field conditions, will be, it is thought, entirely effective in preventing injury without burning of the foliage by the spray. 
The sixth article, Notes on the Peach Bud Mite, brings together information on a creature which is held responsible for a stop-back effect on peach nursery stock, and which has not previously been classified and given a scientific name.

The Grape Scale, comprising the seventh and last paper, deals with an insect which has been the cause of frequent complaint, especially in the environs of Washington, during the past few years. The shedding of bark from the grape is, on the whole, unfavorable to scale insects, yet the present species, in several instances noted, has shown its ability to develop to a decidedly injurious extent.

A. L. Quaintance, In Charge of Deciduous Fruit Insects Investigations. 


\section{CONTENS. ${ }^{1}$}

Spraying experiments against the grape leafhopper in the Lake Erie Valley....................................... Fred Johnson..

Introduction.

Characteristics and habits of the grape leafhopper.

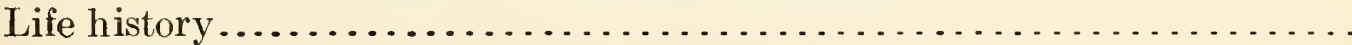

Hibernation.

Page.

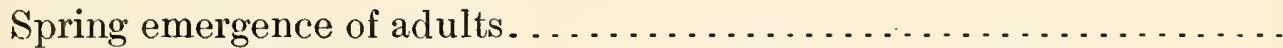

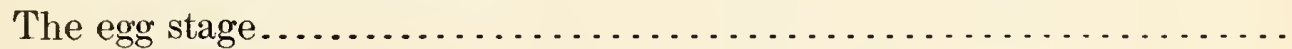

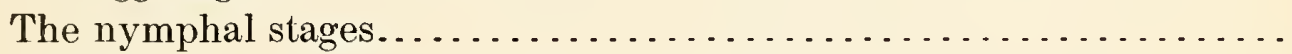

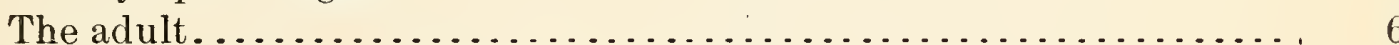

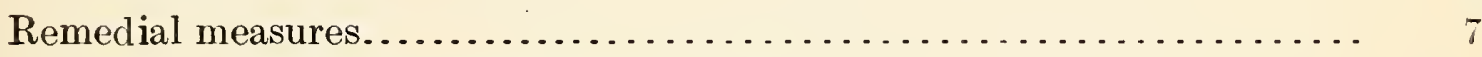

Spray applications against the nymphs................... 8

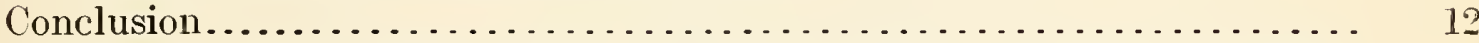

Life history of the codling moth and its control on pears in Califor-

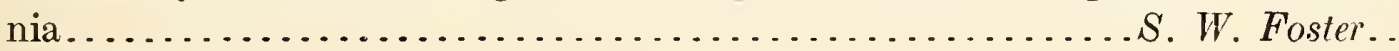

Introduction.

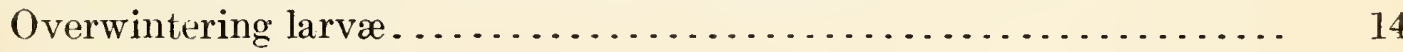

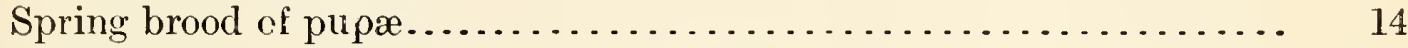

Spring brood of moths................................... 17

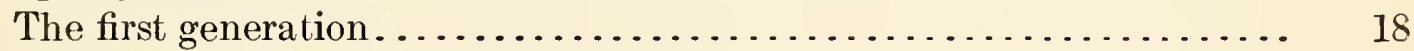

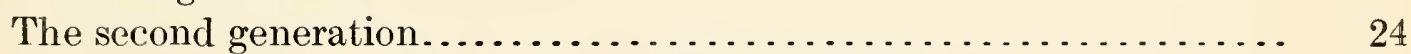

Review of life history for the years 1909 and $1910 \ldots \ldots \ldots \ldots \ldots \ldots . \ldots 26$

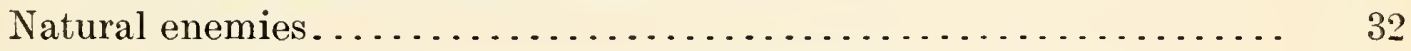

The control of the codling moth on pears in California ............. 32

Effect of sprays on places of entrance into pears by larvæ.......... 33

Commercial results from spraying........................ 41

Summary and recommendations................................ 51

Vineyard spraying experiments against the rose-chafer in the Lake Erie Valley................................. Fred Johnson. .

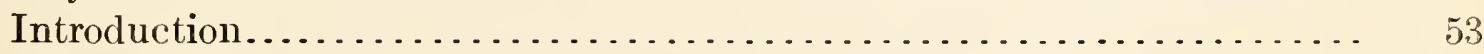

Habits of the adult.............................................. 54

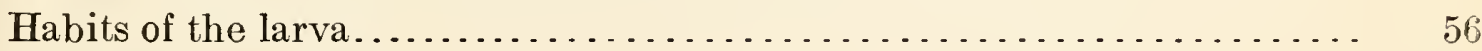

Remedial measures.........................................

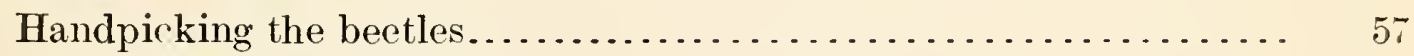

Spraying with arsenicals................................... 58

The use of sweetened arsenicals. . . . . . . . . . . . . . . . . . . 62

Time to make the spray applications................... 63

Cleaning up breeding places...................................... 64

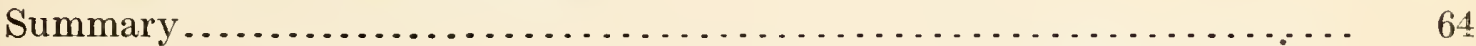

The California peach borer........................ Dudley Moulton.. 65

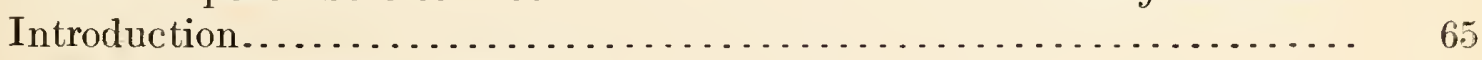

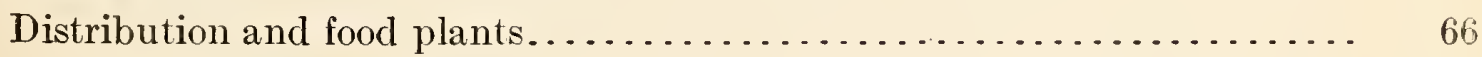

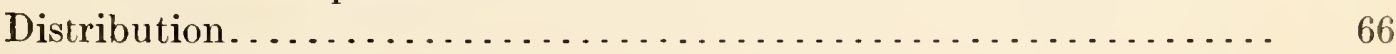

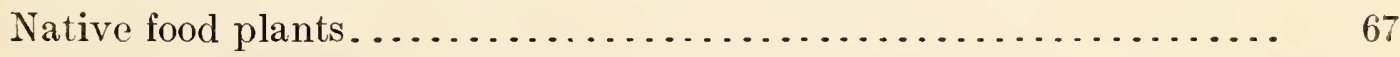

1 The seven papers constituting this publication were issued in separate form on Mar. 31, Apr. 1, Maj 17, Oct. 17, and Nov. 6, 1911, and Feb. 24 and May 4, 1912, respectively. 
The California peach borer-Continued.

Distribution and food plants-Continued.

History of fruit growing in the Santa Clara Valley...

Page.

Limits of areas in which injury occurs

Varieties of cultivated fruits attacked; resistant budding and grafting

stocks; soil conditions as bearing on infestation.

Descriptions, seasonal history, and habits.

The egg...

The larva

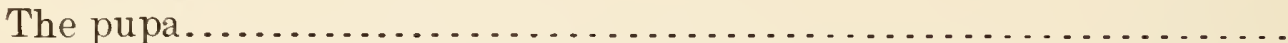

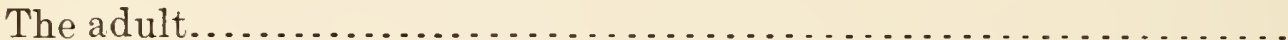

Natural enemies.................................................. 83

Methods of control............................................. 83

Experiments with preventives.......................... 83

"Worming" and applying washes in the Santa Clara Valley........ . 85

Formulas for mashes used................................. 86

The carbon bisulphid treatment.......................... 87

Methods used against the eastern peach borer................ 87

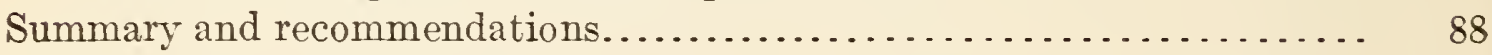

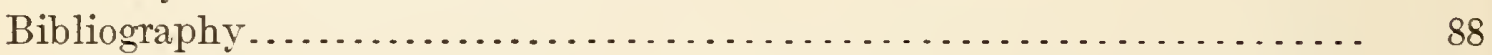

Notes on the peach and plum slug...................... A. Cushman.. 91

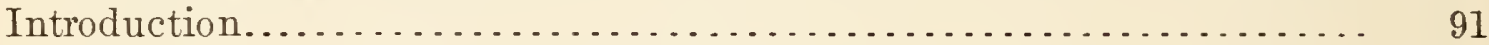

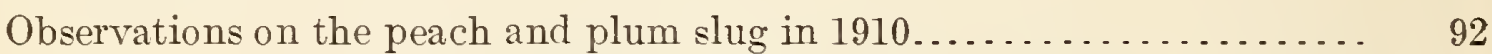

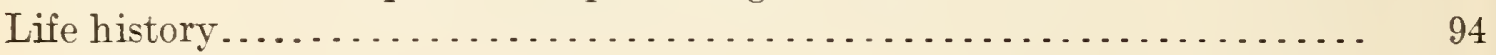

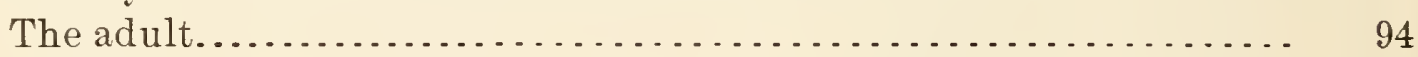

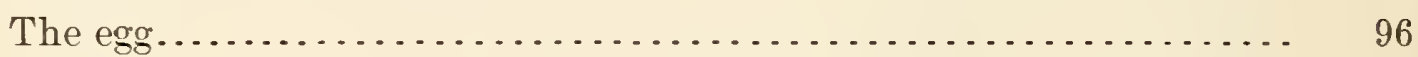

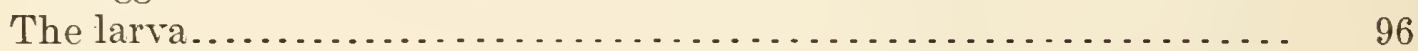

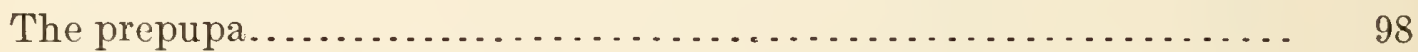

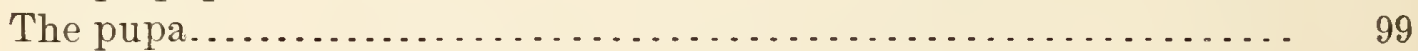

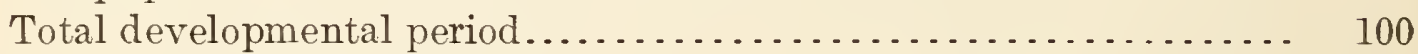

Extent of damage............................................. 100

Natural enemies......................................... 100

Remedies.............................................. 102

The peach bud mite.............................. L. Quaintance. 103

Introduction................................................. 103

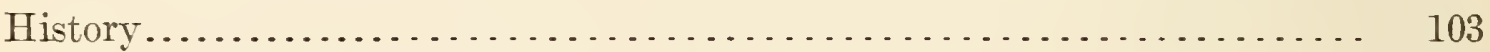

Economic importance................................... 106

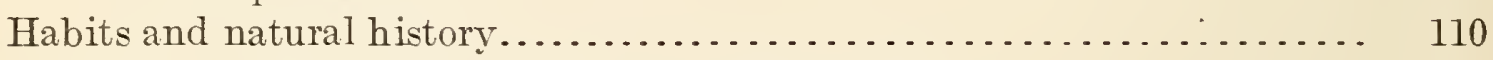

Systematic relationships and other economic species.............. 111

Remedial considerations................................ $\quad 113$

The grape scale............................... James F. Zimmer.. 115

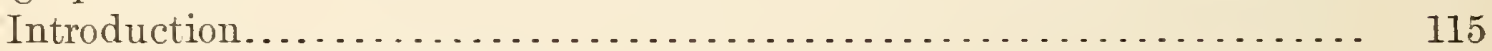

Distribution and food plants. . . . . . . . . . . . . . . . . . . . 115

Habits and natural history............................... 116

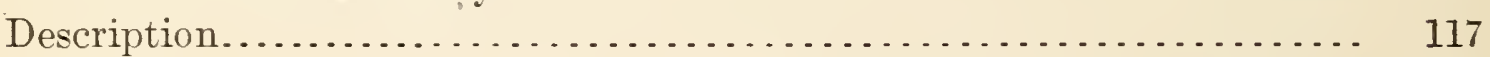

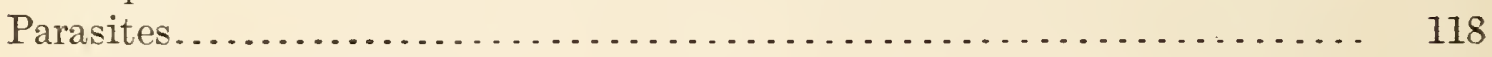

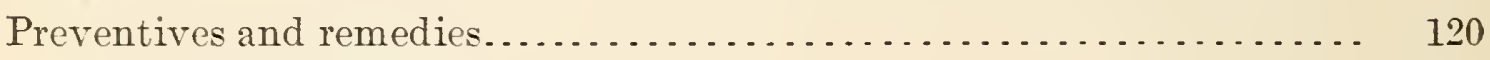

Lime-sulphur wash.................................. 120

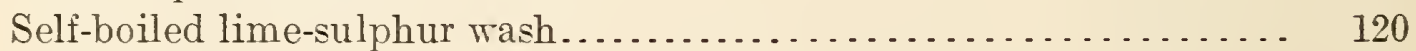

Other sprays.......................................... 121

When to spray......................................... 121

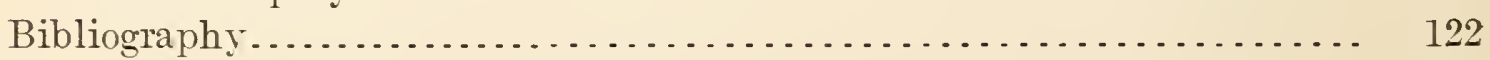

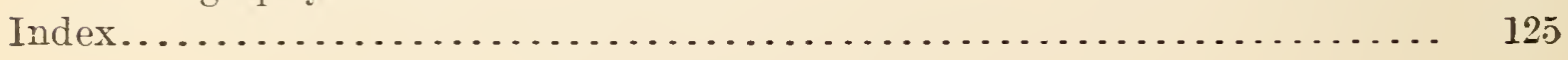




\section{L L USTRATIONS.}

PLATES.

Plate I. Fig. 1.-Cover crop of vetch in vineyard of Mr. John Higgins, North East, Pa. Fig. 2.-Cover crop of turnips in vineyard of Mottier Bros., North East, Pa.; vineyard badly infested by grape leafhopper, which was effectively treated with blackleaf tobacco-extract

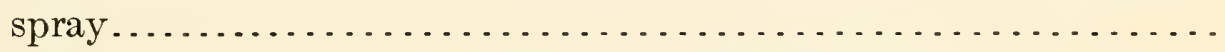

II. Fig 1.-Injury by grape leafhopper (Typhlocyba comes) to unsprayed vines. Fig. 2.-Perfect foliage of sprayed vines. Views from experimental plats in vineyard of Mr. H. H. Harper, at North East,

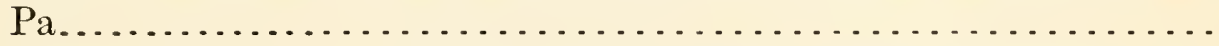

III. General view of the Whitman pear orchard, with power-spraying outfit in operation in spraying experiments against codling moth,

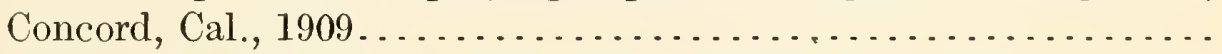

V. Injury by rose-chafer (Macrodactylus subspinosus) to fruit on unsprayed grapevine in the vineyard of Mr. C. F. Hirt, at North

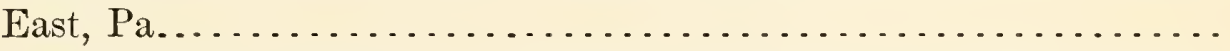

V. The protection afforded by spraying; vine from row adjoining the

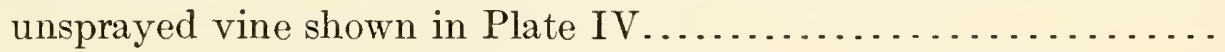

VI. Injury by rose-chafer to fruit on unsprayed grapevine in the vineyard of Mr. George Cook, at North East, Pa..................

VII. Protection afforded by spraying; vine from vineyard of Prospect Park Fruit Farms Co., adjoining vineyard of Mr. George Cook,

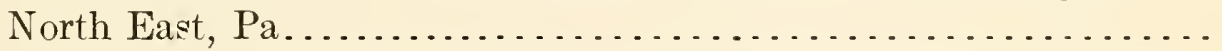

VIII. The California peach borer (Sanninodea opalescens). Apricot orchard, showing trees injured and killed by the borer.........

IX. The California peach borer. Rearing cages in laboratory yard at San Jose, Cal. used in study of its life history . . . . . . . . . . . . .

X. The California peach borer. Fig. 1.-Base of apricot tree, showing injury by larvæ. Fig. 2.-Wire cage, used in determining period of emergence of moths, in place around tree............

XI. Peach leaves showing work of peach and plum slug (Caliroa [Erio-

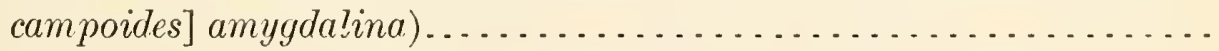

XII. Injury about two weeks old to peach shoots by the peach bud mite

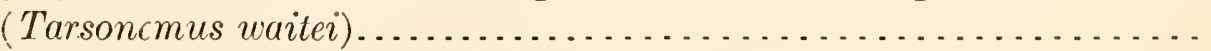

XIII. Injury several weeks old to peach shoots by the peach bud mite....

XIV. Showing condition of peach nursery trees in the fall, due to injury

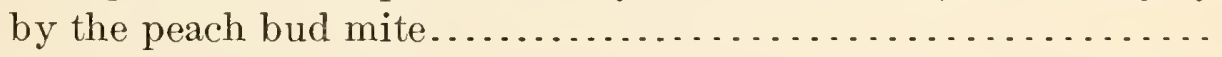

$X V$. Showing condition of peach nursery trees in the fall, due to injury

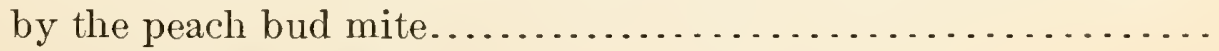

XVI. Injury to buds supposedly due to the peach bud mite...........

XVII. Grape canes showing infestation by the grape scale. Aspidiotus

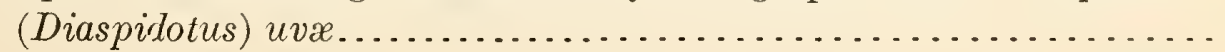


Plate XVIII. The grape scale. Fig. 1.-Showing how the young scales settle, more or less, in longitudinal rows. Fig. 2.-Full-grown male and female scales; also many parasitized individuals. Fig. 3.-Pygidium of adult female, showing circumgenital glands and orifice, lobes, and spines..................

XIX. The grape scale. Fig. 1.-Adult winged male. Fig. 2.-Genitalia of male. Fig. 3.-Antenna of male. Fig. 4.-Serrations on costal vein. Fig. 5.- Tarsus and claw of male..........

Page.

\section{TEXT FIGURES.}

FIG. 1. The grape leafhopper (Typhlocyba comes var. coloradensis): Adult....

2. The grape leafhopper: Nymph of the first molt.................

3. The grape leafhopper: Fully developed nymph of the fifth molt....

4. Grape leaf in early stages of attack by the grape leafhopper, showing the characteristic mottling of the upper surface . . . . . . . . . . .

5. Grape leaf showing final result of attack by the grape leafhopper; leaf withered and brown before the fruit is mature...............

6. Weekly emergence of codling moths from overwintered material at San Jose, Cal., 1909.................................

7. Codling-moth larvæ collected from banded pear trees at Walnut Creek, Cal., 1909.

8. Codling-moth larvæ collected from banded apple trees at Walnut Creek, Cal., 1909.

9. Weekly emergence of codling moths from material collected from banded apple and pear trees at Walnut Creek, Cal., 1909..........

10. Band records from 11 apple trees at Walnut Creek, Cal., 1910.......

11. Band records from 15 Bartlett pear trees at Suisun, Cal., 1910........

12. Weekly emergence of moths from material collected under bands on 11 apple trees at Walnut Creek, Cal., 1910.....................

13. Weekly emergence of moths from material collected under bands on 15 pear trees af Suisun, Cal., 1910 . . . . . . . . . . . . . . . . . . .

14. Band records of the codling moth from apple trees at San Jose, Cal.,

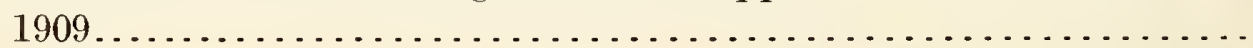

15. Weekly emergence of codling moths from larvæ collected from banded apple trees at San Jose, Cal., 1909.

16. Condition of grape blossom-buds at the time the rose-chafter (Macrodactylus subspinosus) first appears, and when the first poison spray

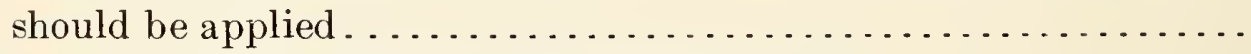

17. Injury by the rose-chafer to grape blossom-buds................

18. The rose-chafer (Macrodactylus subspinosus): Adult, larva and details,

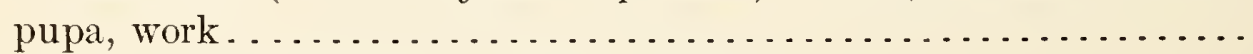

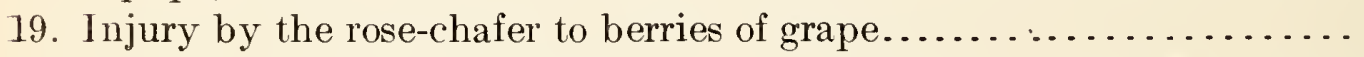

20. Grape cluster showing almost total destruction of berries through

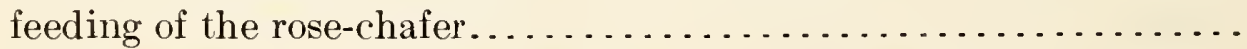

21. Grape clusters from which berries injured by the rose-chafer have fallen

22. The California peach borer: Adult, larva, pupa, and details.......

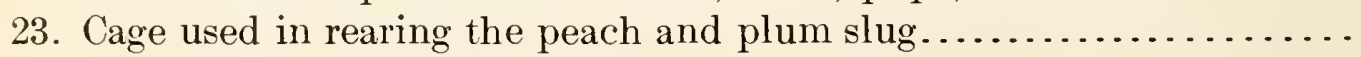

24. Developmental stages of peach and plum slug (Caliroa [Eriocampoides ] amygdalina): Adult, egg, larva, and pupa.............

25. Hyperallus calirox, a parasite of the peach and plum slug...........

26. The grape scale, Aspidiotus (Diaspidiotus) uvæ: Newley hatched larva

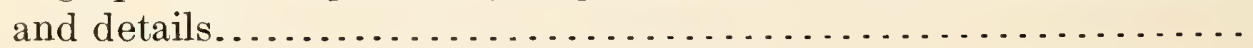

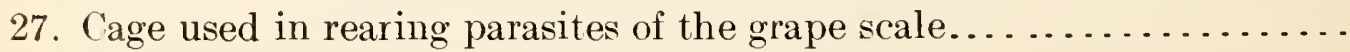




\section{ADDENDUM.}

Page 83, under the heading "Natural Enemies" Cryptus (Hamoplex) tejonensis, Cress. should have been included, since it is a parasite of Sanninoidea opalescens. 



\title{
PAPERS ON DECIDUOUS FRUIT INSECTS AND INSECTICIDES
}

\section{SPRAYING EXPERIMENTS AGAINST THE GRAPE LEAF- HOPPER IN THE LAKE ERIE VALLEY.}

\author{
By Fred JoHnson, \\ Agent and Expert. \\ INTRODUCTION.
}

The grape leafhopper (Typhlocyba comes Say) (fig. 1) is an enemy of grapevines familiar to almost every vineyardist, and doubtless at times it has become so numerous and destructive in his vineyard as to cause him considerable anxiety. Usually, however, in the vineyards of the Lake Erie Valley, serious depredations by this pest are confined to somewhat limited areas adjacent to rough lands and woodlots. A few vines at the ends of the rows or a few rows along the outsicle of vineyards will be injured year after year until the crop yield on these vines is considerably reduced. Under these conditions it receives slight attention from the average vineyardist and is regarded as more or less of a negligible quantity. Periodically, however, some as yet unknown conditions seem to favor its multiplication and it spreads over wide areas causing injury amounting to many thousands of dollars. Such a condition obtained in the vineyards of Chautauqua County, in the vicinity of Westfield, N. Y., during the seasons of 1901 and 1902, when many hundreds of acres of

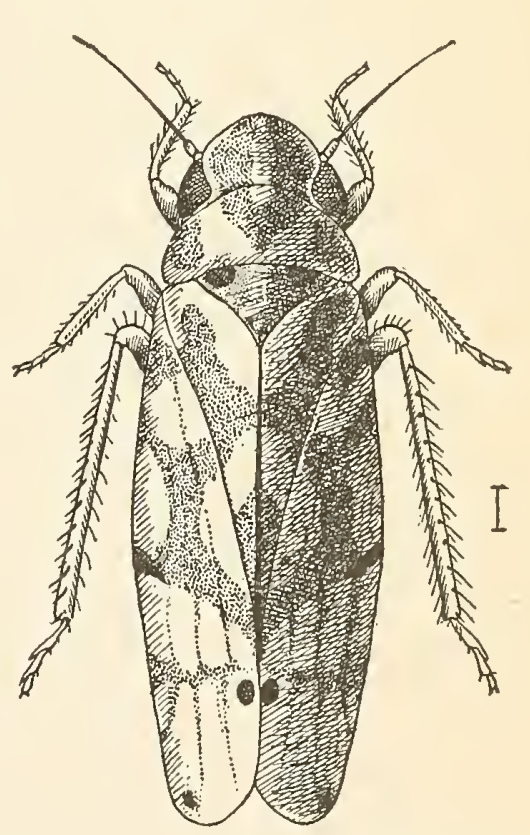

FIg. 1.-The grape leafhopper ( Typhlocyba comes var. coloradensis): Adult. Greatly enlarged. (Original.) vineyards suffered greatly from the injury wrought by this pest. In 1903 the insect disappeared to a considerable extent and serious injury was again confined to limited areas until the season of 1910 . The insect is now manifestly on the increase and during the past season (1910) spread through large blocks of vineyard. In fact, 
toward the latter end of the summer its presence in more or less destructire number's was erident throughout the entire grape belt. By far the greater injury occurred, howerer, in those rinerards portions of which have been continuously infested. With the general increase of this pest throughout the Lake Erie Valley there has dereloped a feeling of anxiety on the part of many rineyardists and a general inquiry is being made as to the best means of holding it in check.

Heretofore the chief factors in the lack of success of the rineyardist in his efforts to combat this pest have been that he has either failed to recognize the most rulnerable stage in its life history or else he has minimized its capacity for injury until this period has passed, only to be filled with regrets later in the season when his rines are swarming with the winged adults and the foliage is so badly injured by them that it presents a brown and scorched appearance which renders it functionless at a period when healthy leaves are necessary to the plant for the purpose of elaborating the sugar of the fruit and for the proper maturing of the new growth so that it will withstand the sererity of the winter and make a rigorous growth in the following spring. If, however, the vineyardist will acquaint himself with the habits and development of this pest there is no doubt that he can combat it successfully when it is in the immature stages, before its wings are fully dereloped, by the thorough application of a contact spray.

\section{CHARACTERISTICS AND HABITS OF THE GRAPE LEAFHOPPER.}

Before proceeding to discuss remedial measures, the primary object of this paper, it may be well to consider briefly the characteristics: habits, and life history of the grape leafhopper, inasmuch as they vary greatly from those of another very destructive pest of the graperine. namely: the grape rootworm.

The grape leafhopper is a minute insect, less than one-eighth of an inch long. The body and wings are of a light yellowish color, and the wings entirely envelop the upper part of the abdomen in a rooflike corering when the insect is at rest. This position of the rings has an important bearing on the killing effect of a contact spray. As the hibernation period approaches, the more pronounced yellow marking of the wings and body changes to an orange-red. which. howerer, exists only during the winter months and disappears after the insect has fed for a short time on the foliage of the rine during the following spring. These winged forms are the mature or adult insects and are the forms most familiar to the casual observer. The adults are frequently found in large numbers leaping and flying actively among the foliage of the rines during the early part of the grape-picking season, in September and early October. Sometimes during bright, 
warm afternoons of early autumn the air will be filled with thousands of these little creatures drifting somewhat aimlessly on the light breeze and causing considerable annoyance by getting into the eyes, ears, and mouth of the beholder.

A close observation of the underside of the leaves of grapevines at this season is likely to reveal the immature or nymphal stage of the insect (fig. 2). These vary greatly in size, from those just hatched to the full-grown nymphs with well-developed wing pads (fig. 3), but they have always the same general form. These leafhoppers belong to the same order of insects as do the scale insects and the plant-lice and secure their food by sucking the juices from the

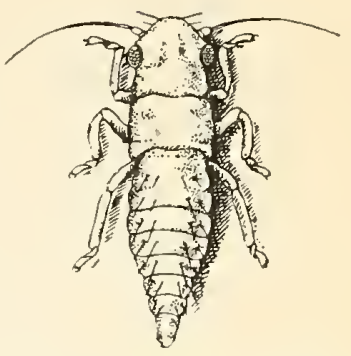

Fig. 2.-The grape le a f hop p r : Nymph of the first molt. Gireatly enlarged. (Original.) plant in much the same manner as the mosquito sucks blood from an animal. A knowledge of this method of taking food is of the greatest importance from an economic standpoint, since insects which take their food in this way are usually amenable to a spray application of

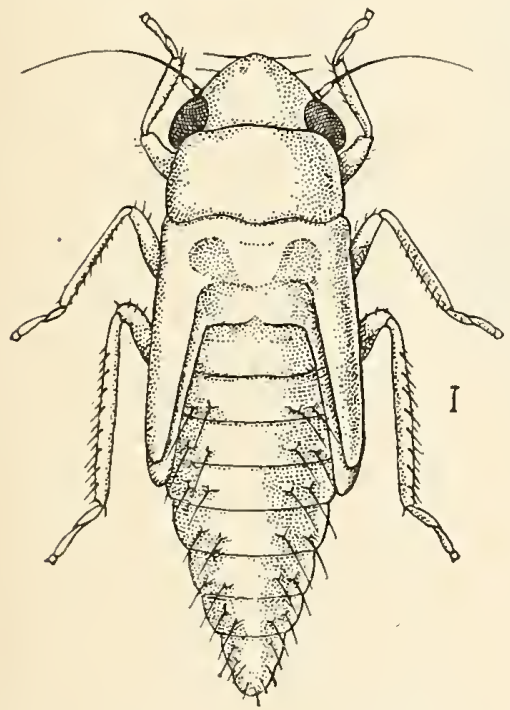

FIG. 3.-The grape leafbopper : Fully develo ped nymph of the fifth molt. Greatly enlarged. (Original.)

an entirely different quality from that which is used in the case of insects which chew or masticate their food. Sucking insects are usually combated by the use of some caustic or smothering substance which must come in direct contact with the outside of the body of each individual, practically at the time of application and in sufficient quantity and strength to effect its almost immediate destruction; whereas, in the case of the chewing insect a stomach poison must be applied, not to the body of the insect, but to the surface of that portion of the plant or fruit upon which the insect feeds.

The adults and the nymphs of the grape leafhopper feed upon the underside of the grape leaf and by sucking the juices therefrom cause it to take on a yellowish, mottled appearance (fig. 4), which later turns brown, and where the infestation is heary the leaves dry out and become functionless before the fruit is mature. (See fig. 5.)

\section{LIFE HISTORY.}

\section{HIBERNATTON.}

The grape leafhoppers pass the winter as winged adults, which migrate from the vines during October. By the time the grapes are harvested only a small percentage of the adults will be found upon 
the vines, although little foliage may have fallen from the vines by that time. During the entire month of October a general dispersion of the adults is in progress throughout the infested area. This dispersion is apparently quite aimless, the individuals settling down and collecting wherever sufficient shelter in the form of fallen leaves, sod lands, hedges, woodlots, and swales is adjacent to the vineyards. Large numbers of them probably never leave the vineyards, passing the winter under the protection afforded by fallen leaves, clumps of grass, weeds, and cover crops. After leaving the grapevines they

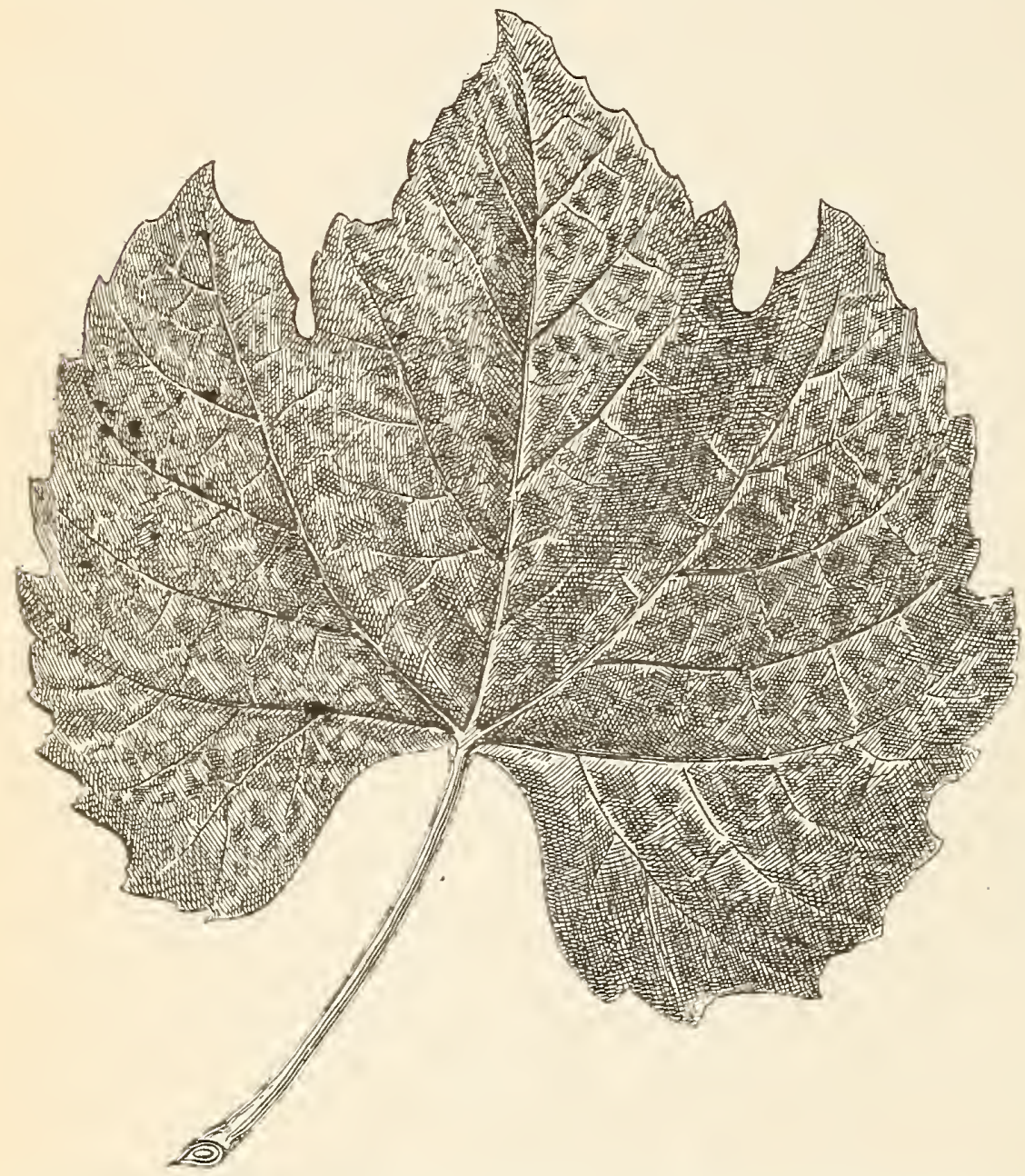

FIG. 4.-Grape leaf in early stages of attack by the grape leafhopper, showing the characteristic mottling of the upper surface. (Original.)

feed to some extent upon the still green grass, weeds, and cover crops, and become more or less actire when disturbed during the warmer days of winter.

SPRING EMIERGENCE OF ADULTS.

Early in May, as the days become warmer and plants commence to throw out new growth, the adults leave their winter protection and feed somewhat ind iscriminately upon the new growth of almost any plant with which they come in contact, showing some preference, however, for the foliage of bush fruits such as wild blackberries, cultivated raspberries, and strawberries. This promiscuous feeding terminates with the unfolding of the leaves of the grapevine and there is a general migration of the insect back to the foliage of the grapevine, this being the only plant upon which this particular species of leafhopper is known to reproduce.

The adult "hoppers" first attack the foliage or sprouts springing from the base of the vine or from canes near the lower wire of the trellis. When the adult insects are very numerous, sufficient injury 
results to check the development of the foliage and to retard the growth of those new shoots which spring from the canes near the lower wire of the trellis. This early retardation of growth is more important than would at first appear, for it is highly desirable that these new shoots springing from the canes near the lower wire of the trellis should make a thrifty growth during the early part of the season, since it is from them that canes for bearing the next season's crop of fruit are selected. This feeding of the overwintering adult "hoppers" continues for several weeks; in fact, many of them may remain upon the vines until some of the new generation has matured.

THE EGG STAGE.

Egg laying by the overwintering females does not commence in the vineyards of the Lake Erie Valley until about June 1, after the adults have been feeding upon the vines for several weeks. The eggs are deposited on the underside of the leaves. They are tucked under the skin indiscriminately as to location on the leaf and are very difficult to locate on those varie-

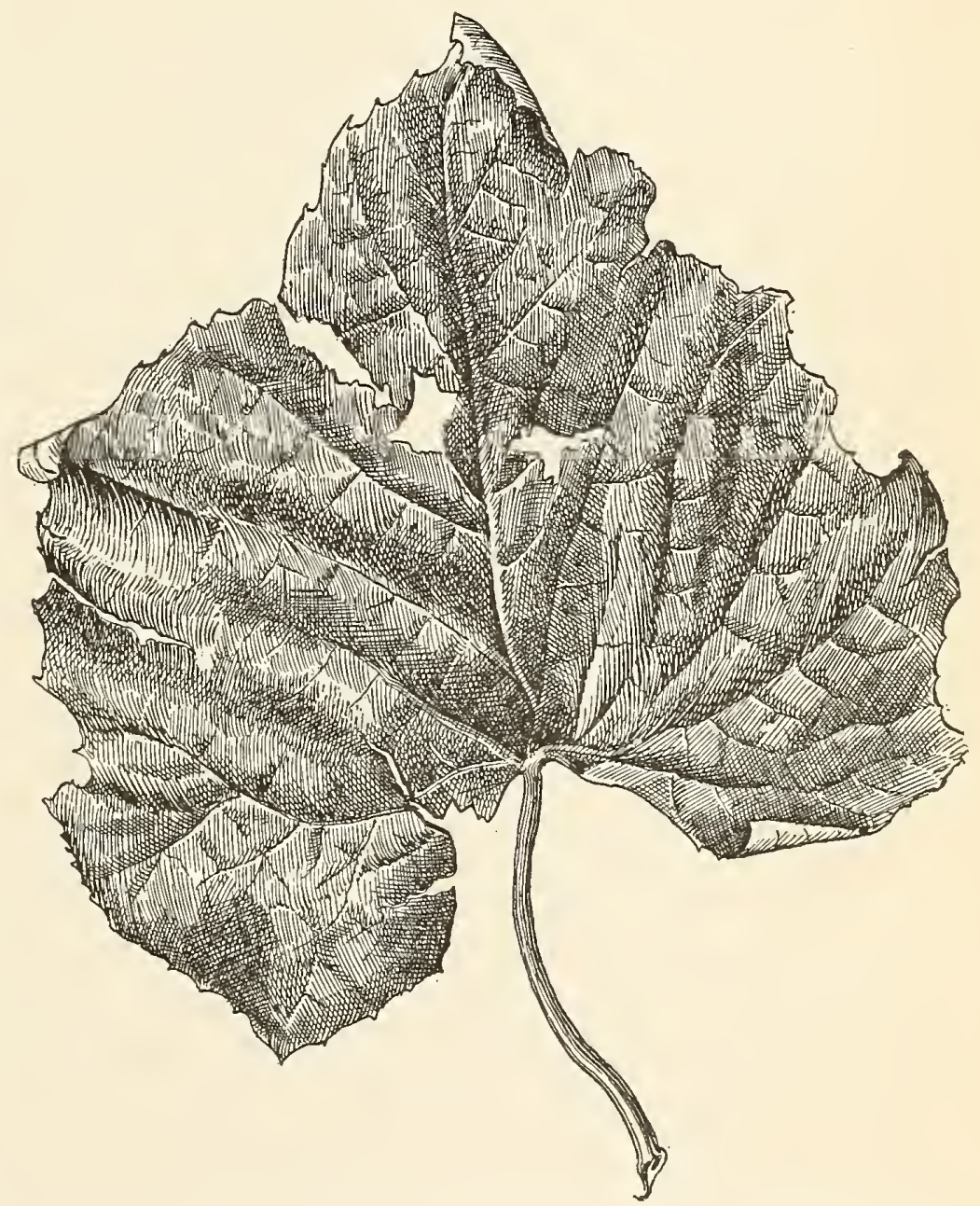

FIG. 5.-Grape leaf showing final result of attack by the grape leafhopper; leaf withered and brown before the fruit is mature. (Original.)

ties possessing a heavy pubescence, as is the case with the Concord. The egg stage covers a period of about 10 days to 2 weeks. The period of egg deposition is obviously a long one, since newly emerged nymphs are present upon the foliage from the middle of June until late in October. Observations indicate, however, that the maximum deposition must occur during the last three weeks in June and the first week in July, since the period when there is a maximum number of nymphs upon the leaves is included in a period from the last week in June until about August 1, at which latter date many fully developed nymphs are making their final molt. 
THE TYMPHAL STAGES.

The young "hoppers," or nymphs, commence to appear about the middle of June, and a close examination of the underside of infested leaves at this time is likely to reveal a number of recently hatched nymphs, at about the stage shown in figure 2, running actirely orer the surface. In hatching from the egg the young "hopper" has to force its way through the pubescence on the underside of the leaf, and in doing so appears as a minute, whitish object, which, when examined under a lens, is seen to possess a pair of red eyes. After a few minutes of laborious struggling it forces itself to the surface of the pubescence, where its legs and antennæ spread and become disengaged and the tiny creature is ready to commence its destructire operations. This it does by thrusting its tiny beaklike mouthparts into the tissue of the leaf and extracting the juices. As the season adrances it is not uncommon to find individual leaves supporting from 200 to 300 of these nymphs in the various stages of nymphal derelopment.

As the nymph increases in size it casts or molts its old skin for a larger one. There are five of these molts before the nymph reaches the adult stage. The first four require a period of $\breve{y}$ days for each molt, and between the fourth and fifth molts there is a period of 12 days. Hence about a month is required in which to complete the nymphal period. Figure 3 represents a nymph after the fourth molt with fully cieveloped wing pads.

The term "hopper" applied to this form of the insect is a misnomer and is likely to create an erroneous impression concerning the morements of the insect at this period of its life history. The nymphs do not hop or leap, as the term "hopper" would imply; and although they run about very actively on the underside of the leaf and sometimes a few of them may be seen rumning down the stem of the leaf and also upon its upper surface, it is doubtful if the journeys of more than a rery small percentage of them extend beyond the confines of the leaf upon which the eggs from which they were hatched rere deposited. This limited area of morement of the insect during this period of its life is exceedingly important from an economic point of view, since it admits of its destruction during the more rapid growing season of the rine and at a period when there is slight possibility of reinfestation of treated areas.

THE ADULT.

Writh the final molt and the full development and use of its wings the adult leafhopper becomes an extremely agile and active creature, leaping and darting rapidly from leaf to leaf at the slightest disturbance, being much more active during the warm weather than on cold, windy days, when it can be dislodged from its shelter under the 
foliage only with considerable difficulty. It is in this stage, as mentioned in a previous paragraph, that the insect becomes disseminated over vineyard areas. Nevertheless, the spread of the adults does not become general until late in the season, when migration for the purpose of hibernation takes place. This feature of its movement was adequately and strikingly demonstrated in several vineyards where experimental work was carried on against the nymphs during the season of 1910 . In no case was there a serious reinfestation of the thoroughly treated vines, although adjoining untreated rows were heavily infested throughout the entire season. Hence, we are led to the belief that widespread dissemination of this pest takes place largely during the fall migration, when the adults rise in the air and are carried by the winds, and, again, during the spring migration, when they leave their winter shelter and return to the vines. Thus the vineyardist who has been successful in destroying the nymphis during the summer need have little apprehension of reinfestation later in the season from adjacent infested and untreated vineyards.

\section{REMEDIAL MEASURES.}

In discussing the subject of remedial measures for the control of an insect pest, it is always highly desirable to take into consideration cultural and other operations involved in the production of the particular crop under treatment in order that the recommendation of methods of control which may conflict with the most desirable farm practice, or may be impracticable on a commercial scale, may be avoided. Modifications in vineyard or orchard management by the adoption of new methods may also seriously conflict with earlier recommendations which were quite feasible when first suggested. Thus, earlier writers have laid considerable stress upon the value of clean culture of vineyards and the gathering up of all trash and leaves in and bordering upon them as a means of greatly reducing the number of overwintering "hoppers." Unfortunately, however, this cleaning-up process is impracticable over large areas, and it not infrequently happens that adjacent rough lands which furnish winter protection outside the vineyards are not under the control of the owner of the vineyard. Furthermore, the practice of growing winter cover crops of clover, vetch, turnips, etc., in vineyards, a practice highly desirable both from the standpoint of increasing. the fertility of the soil and preventing soil wash during the winter months, has become quite general throughout Erie County (see Pl. I, figs. 1 and 2). There is no doubt that cover crops tend to hold more of the hoppers in the vineyards than where clean culture is practiced. Yet many vineyardists are convinced that the ultimate advantage to the vine is so much in favor of the cover crop that they prefer to continue this practice, if possible, and look for some other 
means of controlling the grape leafhopper, and are turning their attention toward a summer spray treatment as a means of control.

The active movements of the overwintering adult "hoppers" when feeding upon the new growth of vines in the early spring and the fact that they are somewhat protected by the wings (which, when the insect is at rest, form a rooflike corering over the softer parts of their body) (fig. 1), greatly lessen the efficiency of a contact spray, first, because of their rapid morements, and, second, because, even if hit by the spray, they are not destroyed unless it is of so great a strength that it would injure the tender new growth of the vine.

Another device for the destruction of these overwintering adults has been the use of shields smeared with some sticky substance. This method, however, is quite laborious, and is practicable only for small areas, and in the opinion of the writer is necessary only when the overwintering insects are very numerous and likely to work great injury to the new growth.

In view of the difficulty to be encountered in overcoming the overwintering adults, and confident that this pest can be controlled by a spray treatment applied during the nymphal stage, the experimental work of the bureau was confined entirely to a spray treatment against the nymphs.

These experiments were undertaken in portions of vineyards which had suffered from attacks of this pest for several years and in which it was becoming more destructive each year, and although the overwintering adults were quite numerous and their injury to the new shoots was much in evidence, no attempt was made to check them in any way.

SPRAY APPLICATIONS. AGAINST THE NYMPHS.

From the middle of June, when the nymphs first commenced to appear, a close watch was kept on their derelopment, the object being to determine approximately the date at which the maximum number of nymphs would be present upon the foliage before those earliest to hatch had developed wings and before serious injury to the foliage (evidenced by a yellow mottling of those leaves most heavily infested by the nymphs) had become apparent. During the summer of 1910 this date was about July 12. At this time a small number of the nymphs earliest to hatch had entered upon their last molt (fig. 3), and the number present upon the leaves in earlier stages of development was very large, indicating that about the maximum number of nymphs was now present upon the foliage.

The first spray application was made July 12, the substance used being blackleaf tobacco extract, a dark, almost viscid liquid containing $2_{4}^{3}$ per cent nicotine.

Since no data were at hand to indicate the minimum strength at which the solution would kill the nymphs it was necessary to spray 


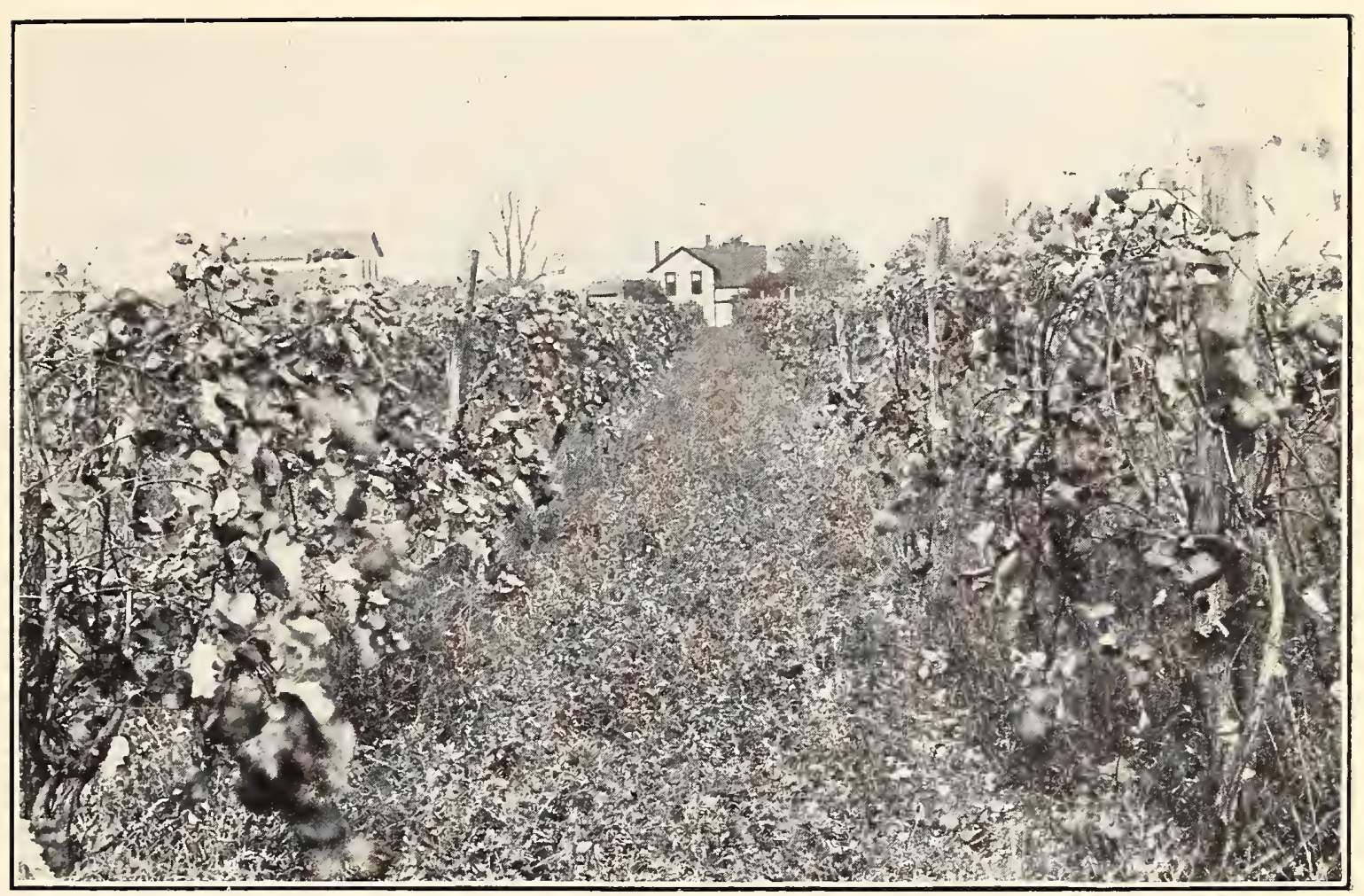

Fig. 1.-Cover Crop of Vetch in Vineyard of Mr. John higgins, North East, PA. (ORIGINAL.)

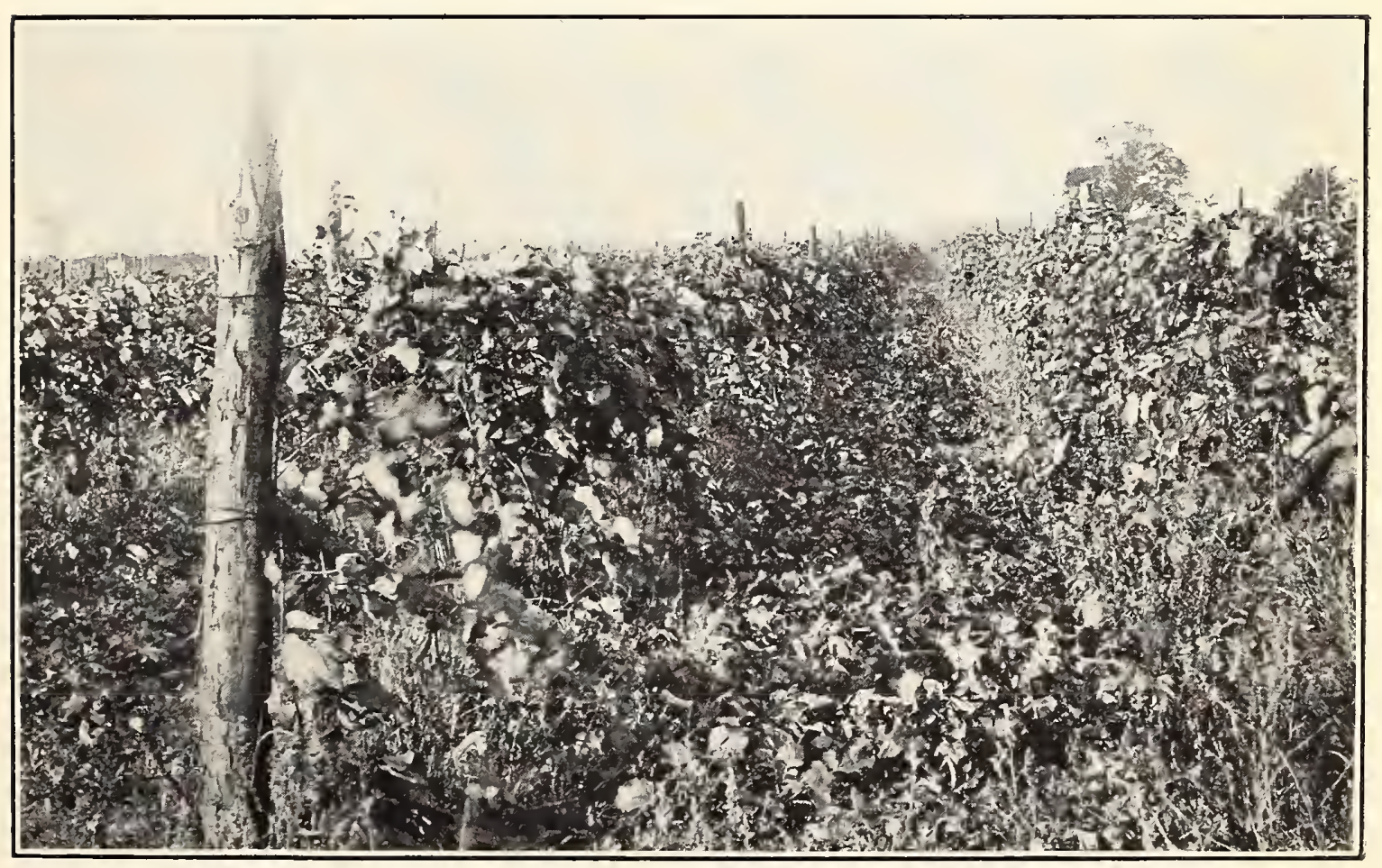

Fig. 2.- Cover Crop of Turnips in Vineyard of Mottier Bros., North East, Pa. Vineyard Badly INFEsted by Grape LeafHopper, Which Was EFfectively Treated with Blackleaf Tobacco-Extract Spray. (Original.) 

a few vines with different dilutions. Accordingly several vines were sprayed with the following dilutions:

TARLE 1.-Dilutions of blackleaf tobacco extract as used in experiments against the grape leafhopper.

\begin{tabular}{|c|c|c|c|}
\hline $\begin{array}{l}\text { Plat } \\
\text { No. }\end{array}$ & $\begin{array}{l}\text { Num- } \\
\text { ber of } \\
\text { vines. }\end{array}$ & Strength of dilution. & Results. \\
\hline $\begin{array}{l}1 \\
2 \\
3 \\
4 \\
5 \\
6\end{array}$ & $\begin{array}{l}4 \\
4 \\
4 \\
4 \\
4 \\
4\end{array}$ & 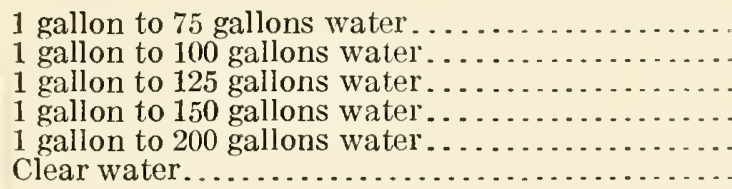 & $\begin{array}{l}\text { All nymphs hit by spray were killed. } \\
\text { Do. } \\
\text { Do. } \\
\text { Do. } \\
\text { Do. } \\
\text { No nymphs killed. }\end{array}$ \\
\hline
\end{tabular}

Blackleaf " 40," another form of highly concentrated tobacco extract, was also used at a much greater dilution, as shown in Table II. TABLE II.-Ditutions of blackleaf " 40 " as used in experiments against the grape leafhopper.

\begin{tabular}{|c|c|c|c|}
\hline $\begin{array}{l}\text { Plat } \\
\text { No. }\end{array}$ & $\begin{array}{l}\text { Num- } \\
\text { ber of } \\
\text { vines. }\end{array}$ & Strength of dilution. & Results. \\
\hline \begin{tabular}{l|l}
1 & \\
2 & \\
3 & \\
4 & \\
5 &
\end{tabular} & $\begin{array}{l}4 \\
4 \\
4 \\
4 \\
4\end{array}$ & 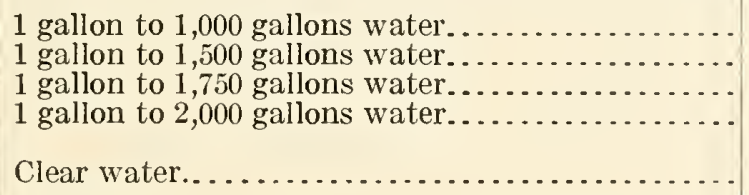 & $\begin{array}{l}\text { All nymphs hit by spray were killed. } \\
\text { Do. } \\
\text { Do. } \\
\text { All but fully developed nymphs were } \\
\text { killed. } \\
\text { No nymphs were killed. }\end{array}$ \\
\hline
\end{tabular}

All of the spray applications indicated above were made with a hand pump carrying a pressure of about 80 pounds. A short rod with a nozzle set at right angles attached to a 40 -foot hose was used to apply the spray to the nymphs upon the underside of the leaves. Great care was taken to wet the underside of every leaf. The result of these applications could be determined within an hour after they were made, or as soon as the leaves became dry. Those nymphs that were not hit and killed by the spray would be found running about quite actively; thus the efficiency of the spray was quickly apparent. It was found that a larger amount and a greater strength of the tobacco liquid was required to kill the nearly full-grown nymphs, and also that only a very small number of the winged adults was destroyed by the spray.

After the killing strength of the blackleaf tobacco extract had been determined, several experiments covering areas of several acres each were undertaken in a number of vineyards. On the vineyard of $\mathrm{Mr}$. H. H. Harper about 6 acres of the worst infested portion of his vineyard was sprayed from July 14 to July 16, when the majority of the nymphs were small. Blackleaf tobacco extract was applied at a dilution of 1 gallon of the extract to 150 gallons of water. A traction sprayer was used and a pressure of from 75 to 125 pounds 
was carried. The cause of this great variation in pressure was due to the fact that it is impossible to wet the underside of all of the leaves if the machine is stopped at frequent intervals.

The spray was applied to the underside of the foliage by means of what is known in vineyard spraying operations as a "trailer"that is, instead of delivering the spray to the foliage from nozzles attached to a fixed rod upon the spraying machine a $\frac{1}{2}$-inch hose from 20 to 40 feet long is attached to the discharge of the pump. To the free end of this lead of hose is connected a $\frac{1}{4}$-inch rod about $2 \frac{1}{2}$ feet long carrying either one or two nozzles of the cyclone type set upward at right angles to the rod. This short rod is held by the operator and is thrust in among the leares of the vine and quickly moved about and withdrawn, requiring rapid movements in order to cover the underside of all of the leaves and at the same time not waste much of the liquid. The operator must always bear in mind that the spray liquid must come in contact with each individual nymph that is to be destroyed. This is the only method known to us at present of making a liquid spray application effective. We have made several attempts to deliver the spray to the underside of the foliage by means of nozzles fixed to the machine but have achieved only partial success by that method.

By many vineyardists this "trailer" method of application has been considered slow and expensive. Yet, as worked out this season on the experimental plats of the Bureau of Entomology it has not proved more so than applications made for other vineyard pests.

The cost of the application on the vineyard of Mr. H. H. Harper at North East, Pa., was as follows: Blackleaf tobacco extract at a dilution of 1 to $1 \breve{0} 0$ cost approximately one-half cent per gallon.

The area of vineyard covered per day was 3 acres, and the items of expense were as follows:

One man to operate spray rod_______________-_per day_- $\$ 1.75$

Team to haul sprayer-_-_-_-_._- 2. 25

One boy to dirive team

Cost of spray liquid for 3 acres_-_-_-_-_-_-_-_-_-_do_-_ 2.40

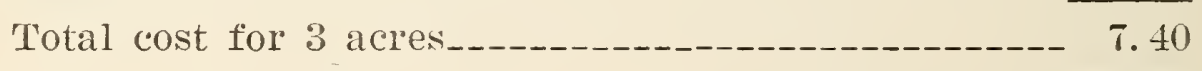

Total cost per acre --_-_-_-_-_-_.-_ 47

A block of 11 acres of badly infested vineyard belonging to Mr. G. E. Pierce was sprayed July 14 to 16 with blackleaf extract, using 1 gallon of the extract to 100 gallons of water. The "trailer" method of application was employed as in the previous experiment. In this instance, however, two nozzles were used and about 200 gallons of liquid were applied per acre. This increase in the strength of the liquid and of the quantity employed raised the total cost of the application to $\$ 3.75$ per acre. A part of this increased cost of application, however, was occasioned by trouble with the water supply during 


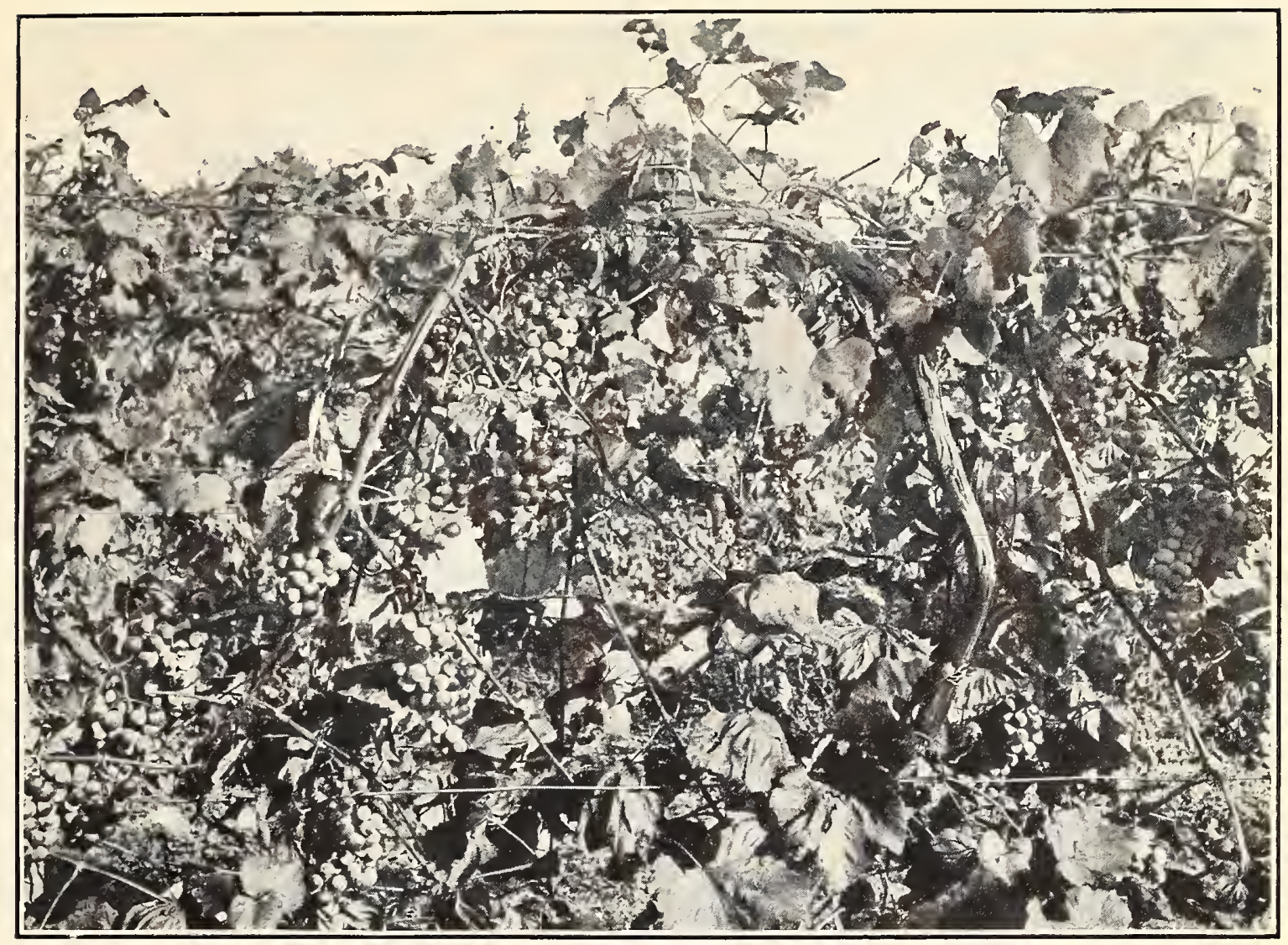

FIG. 1.--INJURY BY GRAPE LEAFHOPPER (TYPHLOCYBA COMES) TO UNSPRAYED VINES. (ORIGINAL.)

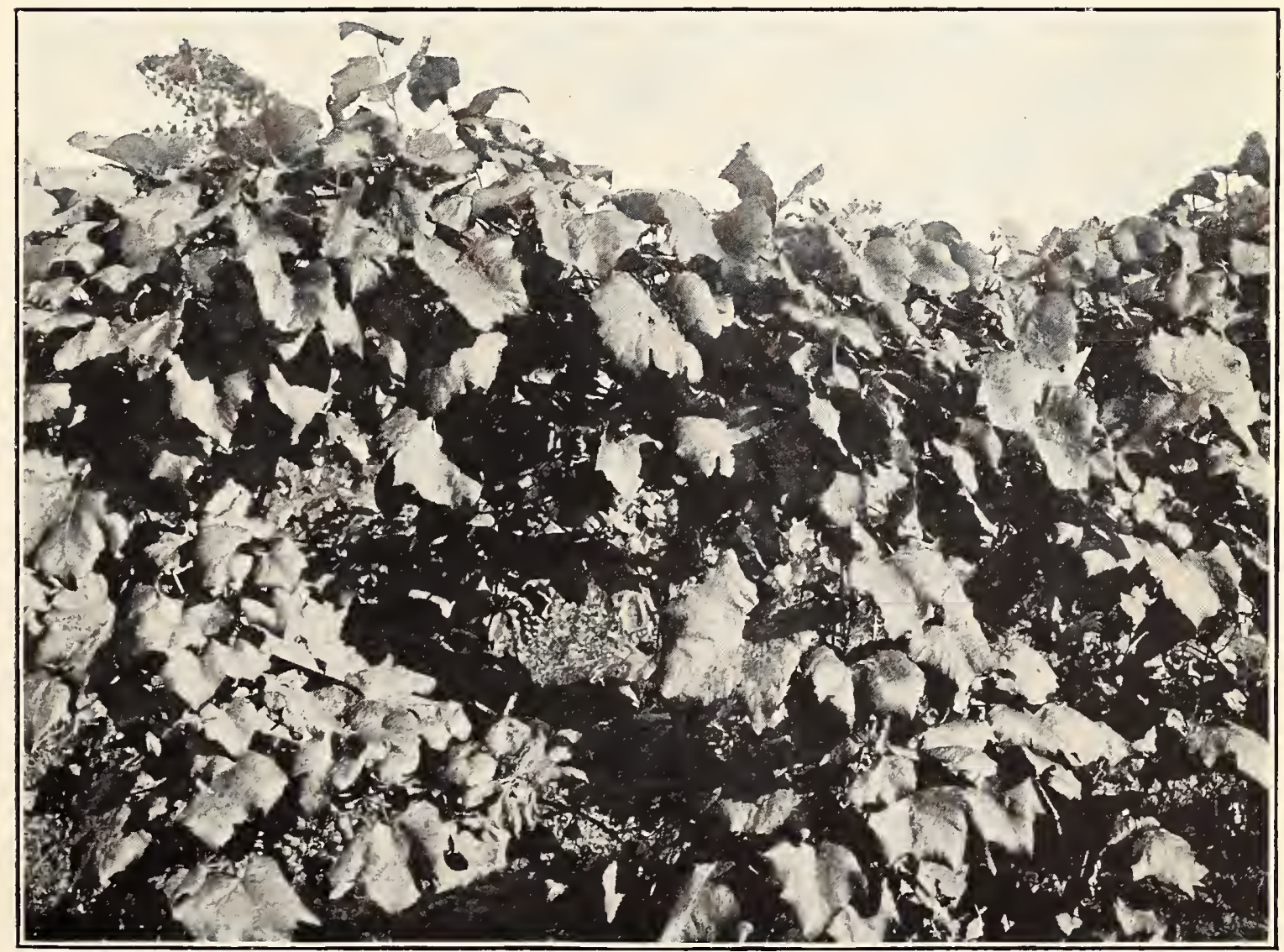

Fig. 2.-PERfect Foliage of Sprayed Vines. VIEWS from EXPerimental Plats in Vineyard of Mr. H. H. Harper, at North East, Pa. (Original.) 

this spraying, and Mr. Pierce is confident that under favorable conditions the cost per acre could be materially reduced.

A portion of the vineyard on the farm of Mr. John Higgins which has been seriously infested by the grape leafhopper, to which he attributes the shrinkage of several thousand baskets of fruit during the past two or three seasons, was treated in the same manner as the vineyard of $\mathrm{Mr}$. H. H. Harper.

On three blocks, however, the strength was varied as follows: Blackleaf tobacco extract, 1 gallon to 75 , to 100 , and to 150 gallons of water. As far as could be observed the dilution to 150 gallons of water was as effective as that to 75 gallons. All of the applications mentioned above were made before any of the nymphs had completed the final molt, and all of them were highly effective in reducing the number of the nymphs to a point where their injury for the remainder of the season was very slight. On all of these treated blocks the foliage remained dark green and growth continued until quite late in the season, whereas in adjacent infested and unsprayed vineyards the foliage commenced to turn brown before the fruit was ready to pick. In fact, the sprayed and the unsprayed portions of these vineyards were readily distinguished within two or three weeks after the application was made, and the difference in the condition of the foliage became more marked as the season advanced.

Plate II shows photographs of vines taken in the experimental vineyard of Mr. H. H. Harper. Figure 1 is an unsprayed vine, and shows the exposure of the fruit by loss of a part of the foliage and also the withered condition of the leaves still attached to the vines, as a result of grape leafhopper injury. Figure 2 shows the perfect condition of the foliage on a vine growing in the adjacent row which was sprayed with tobacco extract. There is just as much fruit on the vine shown in figure 2 as on the vine shown in figure 1, but owing to the perfect condition of the foliage it can not be seen. The injurious effect of this pest upon the crop yield is cumulative. As a result of several seasons of infestation the cane growth of the vine is stunted during the growing season, and the final outcome is a sickly vine producing small clusters of poorly ripened fruit.

The owners of all of these vineyards were satisfied with the results of these experiments, and are planning to treat their entire vineyards with the tobacco extract next season if the insect is present in them in injurious numbers.

As the season advanced toward August 1, vineyardists began to observe the serious nature of the injury wrought by this pest. Most of them were unprepared to treat it, however, since they had no spraying material on hand, and many of the nymphs were passing from the last molt and developing wings. Nevertheless it was possible to undertake another experiment on the vineyard of Mr. Charles 
Mottier on August 3. At this date many of the nymphs had developed to adults and these were very active.

The blackleaf tobacco extract was used at a strength of 1 gallon to 100 gallons of water and applied in the same manner as in the previous experiments. Evidence of injury, namely, the yellowing of the infested foliage, was already noticeable. Shortly after the application was made, however, it was observed that the yellowing and browning of the foliage ceased on the sprayed portion, whereas on the untreated portion of the vineyard it increased, and by the end of September the difference in color and vigor of the foliage on the two blocks was very marked, although not so much so as in the blocks that were sprayed about the middle of July before any of the nymphs had attained full growth and developed wings. This indicates that the best results can be obtained by treating the nymphs before they commence to make too heavy a drain on the vines. An additional reason why the earlier application of the tobacco extract is desirable is that if it is applied earlier in the season, when the nymphs are small, a weaker dilution may be used. There are thus several adrantages for the earlier application: First, the cost of the material is reduced; second, the drain on the foliage wrought by the large numbers of nymphs is checked; and, third, the possibility of tainting the berries of the fruit with the taste of tobacco-a condition that was slightly noticeable upon the fruit in the rineyard which received the latest treatment of the season-is avoided.

\section{CONCLUSION.}

For several years past injury by the grape leafhopper in the vineyards of the Lake Erie Valley has been confined to limited areas. Its increase and dissemination during the season of 1910 , however, should be a warning to the vineyardist to be prepared to combat it during the coming season if the adults are at all numerous when the vines "leaf out" in the spring.

On account of the inability of the nymphs to escape from the underside of the grape leaves and because of the soft and unprotected condition of their bodies the nymphal period is the most vulnerable stage of the insect. Unfortunately this is the stage at which the insects are the least conspicuous to the casual observer. For this reason in vineyards where the adults are common in early spring an examination of the underside of the foliage should be made during the early part of July. If the nymphs are at all numerous a single thorough spray application of blackleaf tobacco extract applied to the underside of the leaves before wings are developed will reduce their numbers to such an extent that those remaining will neither seriously curtail the growth of the vine nor impair the quality of the fruit. 


\title{
PAPERS ON DECIDUOUS FRUIT INSECTS AND INSECTICIDES.
}

\section{LIFE HISTORY OF THE CODLING MOTH AND ITS CONTROL ON PEARS IN CALIFORNIA.}

\author{
By S. W. Foster, \\ Agent and Expert.
}

\section{INTRODUCTION.}

The codling moth (Carpocapsa pomonella I.) in California presents certain differences in its life history as compared with what is true for the East, principally a lengthening of the respective stages, due to a lower mean temperature during their period of development, especially in the first generation. As remedial measures can only be properly prescribed when based on a complete knowledge of the insect to be controlled, such observations as were possible on the life history of the insect in the vicinity of Walnut Creek were made during the seasons of 1909 and 1910. These, with field notes from other sections during 1910, are given in the following pages. For comparison, and also to further supplement the writer's own observations, some data from San Jose, Cal., are included, as secured by Mr. F. L. Young, of the Bureau of Entomology, working under the direction of Mr. P. R. Jones.

The pear crop of California suffers much from injury by the codling moth, and in view of the commercial importance of this crop, the losses represent in the aggregate a large item. The injury is especially important on green fruit destined for shipment to eastern markets, but even in the case of drying stock there is without doubt an important deterioration in quality. The results of experiments reported in this paper show that much may be done to lessen this damage by two or three timely applications of poison sprays, and it is hoped the recommendations may prove of value to California pear growers.

The writer desires to acknowledge the assistance of Mr. E. J. Hoddy, formerly of this bureau, in helping with part of the spraying experiments and in taking results. Also, to express thanks to 
Mr. G. W. Whitman and Dr. F. W. Bancroft, of Concord, Cal., and Mr. G. W. Langdon, of Suisun, Cal., for their hearty cooperation in furnishing labor and material to help in the experiments.

\section{LIFE-HISTORY NOTES ON THE CODLING MOTH IN CALIFORNIA.}

\section{OVERWINTERING LARVE.}

Many codling-moth larræ could be found in the orchards and around the packing sheds during the winter of 1908-9, but all obserrations go to show that a comparatively small percentage of the larræ maturing in fruit the previous season went through the winter successfully. This may be partly explained by the fact that the pears are picked and taken to the sheds while a large percentage of the second-brood larræ is still in the fruit. Many of these larvæ are destroyed or taken so far away that the adults fail to get back to the trees in spring. Howerer, larvæ were frequently found under old burlap bands left on trees, and in the cracks and crevices and under rough bark.

\section{SPRING BROOD OF PUPA.}

The earliest date of actual pupation was not obserred, but the first pupa was found on March 11, 1909. In removing the bands from seren pear trees in the I'gnacio Valley near Walnut Creek, 8 larræ and 2 pupæ were found. The next day, March 12, 32 larvæ and 6 pupæ were found in the same orchard. March 22, another search showed 7 larvæ and 6 pupæ. On March 23, while looking through some boxes at a rinegar factory, 16 larræ and 9 pupæ were found. These boxes had been kept under shelter during winter. One freshly shed pupal skin was found in the corner of a box, indicating that the first larva had perhaps pupated in February. On March 27, 14 pupæ and 1 pupal skin but no larvæ were found under bands.

The larvæ collected on these dates, together with a small sending from San Jose, were kept separately in vials, with bits of paper and cloth, for pupal records. Records kept at San Jose showed the first pupa on February 20. (See Table III.)

During February, 1910, about 300 larvæ secured from banded trees the previous season were put in vials for individual pupation records. Four of these larvæ had pupated by March 12. Of the 118 which produced adults in spring, 95 had pupated by March 31 and all had pupated April 10. The dates of pupation are given in Table II. Practically all larvæ under observation out of doors at the laboratory at Walnut Creek in 1909 and 1910 and San Jose in 1909 had pupated by the last of April, giving some two months during which larvæ transformed to pupæ. From the appearance of the first pupa, February 20, till the emergence of the last moths from overwintering 
larvæ, in early June, gives some three months for the transformation period of all the overwintering larvæ to adults.

Length of pupal period.-The time spent in the pupal stage varies considerably for different individuals, but all of this brood in 1909 required a month or more, the average time being 39.54 days. (The period of emergence of moths lasts some two months, from the first to the last appearing individuals.) Individual records were started in the spring of 1909 for 128 larvæ, but moths emerged from only 68 . These records are given in Table $I$.

TABLE I.-Dates of pupation, duration of pupal period, and dates of emergence of moths of the spring brood from overwintering larvæ, Walnut C'reek, Cal., 1909.

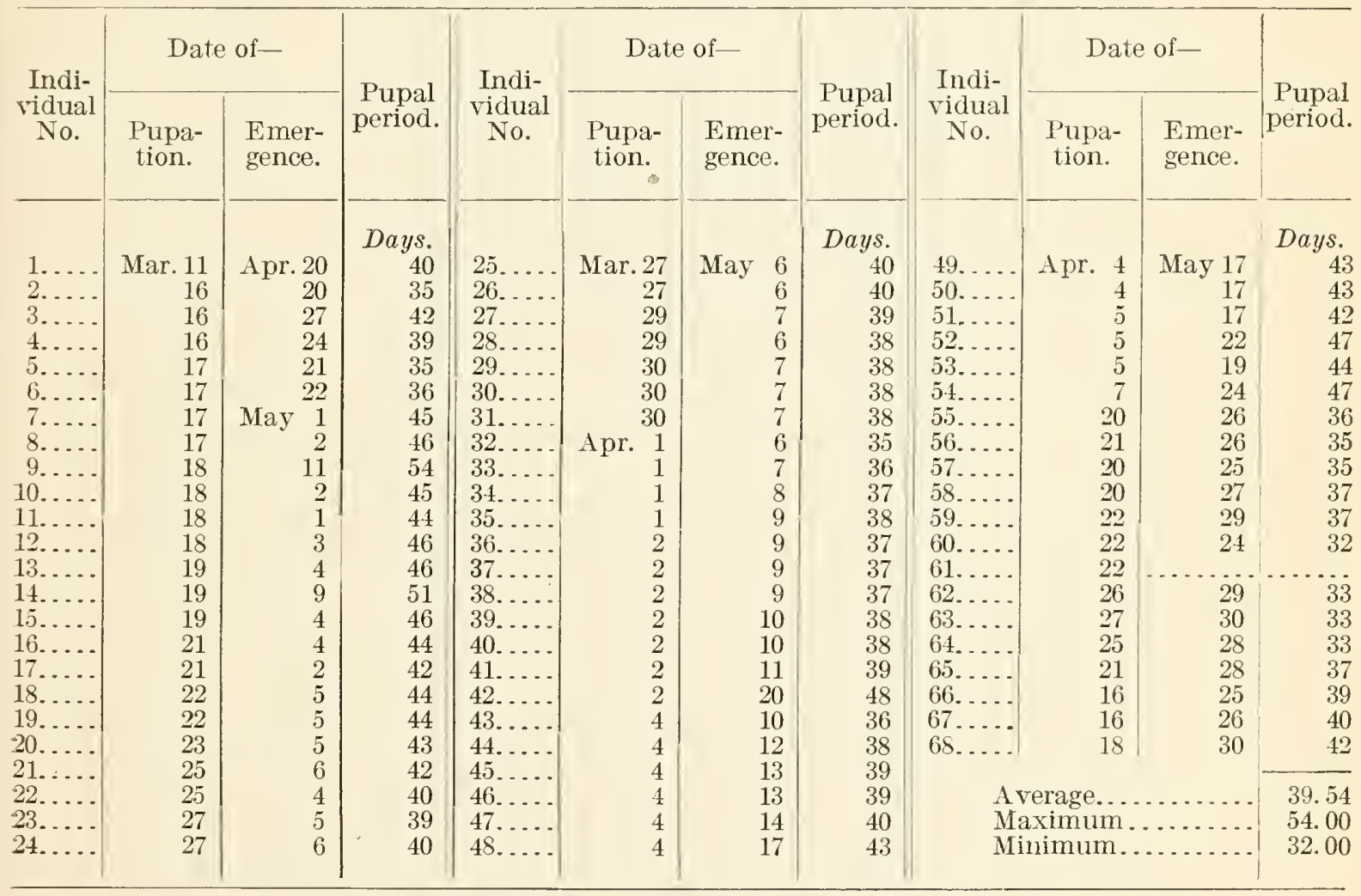

From some 300 larvæ put in vials for individual records in February, 1910, 118 completed pupation and produced adults. Records of these are given in Table II. As will be seen, the pupal period was shorter for the spring brood in 1910 than was the case in 1909. In 1910 the minimum was 21 days, with a maximum of 46, averaging 30.86 days for all individuals under observation, as against an average of 39.54 days in 1909 . 
TABLE II.-Dates of pupation, duration of pupal period, and dates of emergence of moths of spring brood from overwintering larvæ, Walnut Creek, Cal., 1910.

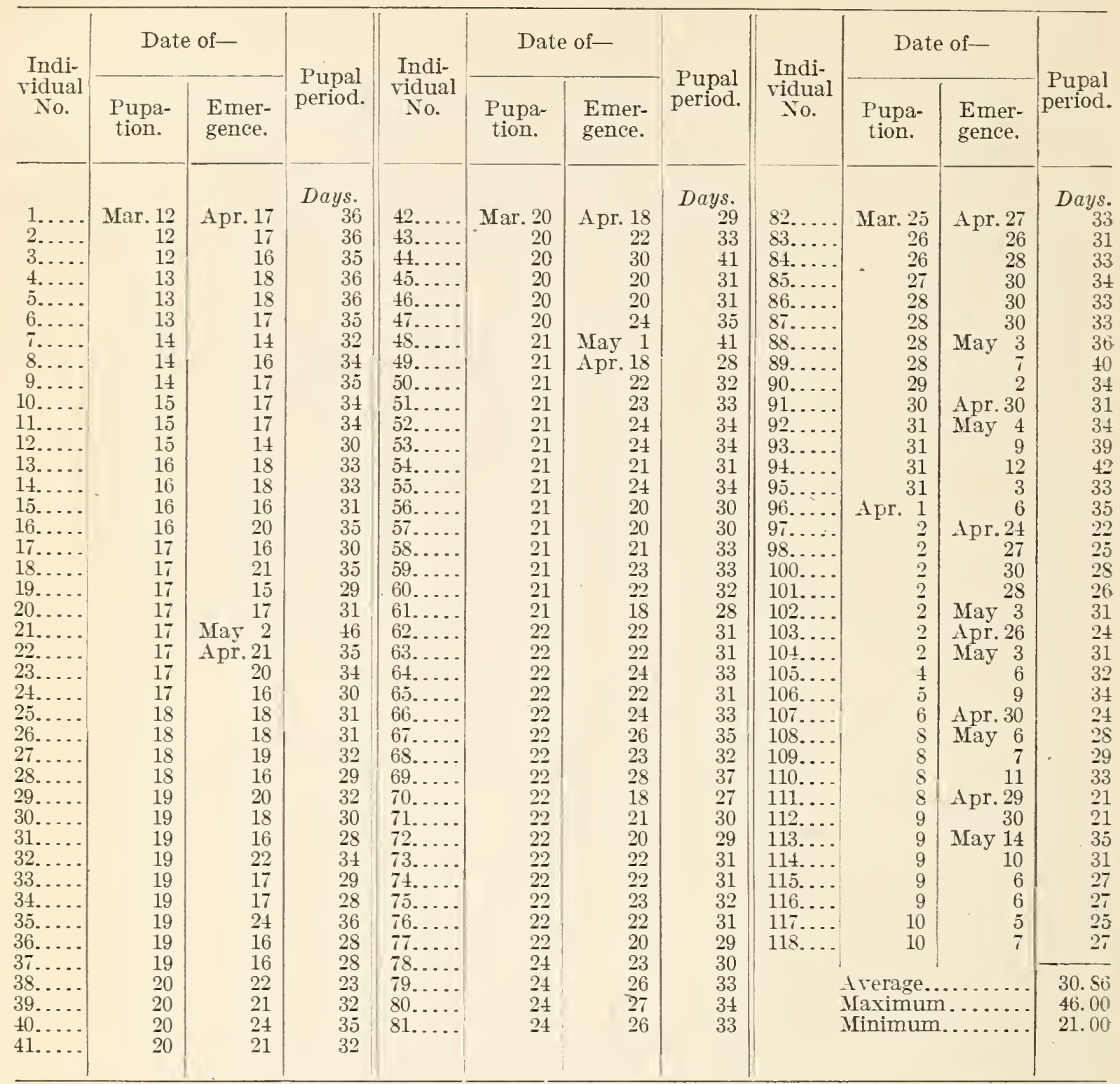

Table III gives records for 31 larvæ which pupated in rials out of doors at San Jose, Cal., in the spring of 1909.

TABLE III.-Dates of pupation, duration of pupal period, and dates of emiergence of moths of spring brood from overwintering larvæ, Sar Jose, Cal., 1909.

\begin{tabular}{|c|c|c|c|c|c|c|c|c|c|c|c|}
\hline \multirow{2}{*}{$\begin{array}{l}\text { Indi- } \\
\text { ridual } \\
\text { No. }\end{array}$} & \multicolumn{2}{|c|}{ Date of- } & \multirow{2}{*}{$\begin{array}{l}\text { Pupal } \\
\text { period. }\end{array}$} & \multirow{2}{*}{$\begin{array}{l}\text { Indi- } \\
\text { vidual } \\
\text { No. }\end{array}$} & \multicolumn{2}{|c|}{ Date of- } & \multirow{2}{*}{$\begin{array}{l}\text { Pupal } \\
\text { period. }\end{array}$} & \multirow{2}{*}{$\begin{array}{l}\text { Indi- } \\
\text { vidual } \\
\text { No. }\end{array}$} & \multicolumn{2}{|c|}{ Date of- } & \multirow{2}{*}{$\begin{array}{l}\text { Pupal } \\
\text { period. }\end{array}$} \\
\hline & $\begin{array}{l}\text { Pupa- } \\
\text { tion. }\end{array}$ & $\begin{array}{l}\text { Emer- } \\
\text { gence. }\end{array}$ & & & $\begin{array}{l}\text { Pupa- } \\
\text { tion. }\end{array}$ & $\begin{array}{l}\text { Emer- } \\
\text { gence. }\end{array}$ & & & $\begin{array}{l}\text { Pupa- } \\
\text { tion. }\end{array}$ & $\begin{array}{l}\text { Emer- } \\
\text { gence. }\end{array}$ & \\
\hline $\begin{array}{l}1 . . \\
2 . . \\
3 . . \\
4 . . \\
5 . . \\
6 \ldots \\
7 . . \\
8 . . \\
9 . . \\
10 . . \\
11 . . \\
12 . .\end{array}$ & $\begin{array}{r}\text { Feb. } 20 \\
\text { Mar. } 5 \\
29 \\
\text { Apr. } 9 \\
\text { Mar. } 23 \\
15 \\
26 \\
27 \\
9 \\
4 \\
\text { Apr. } 1 \\
\text { Mar. } 30\end{array}$ & $\begin{array}{rr}\text { Apr. } 17 \\
26 \\
\text { May } 3 \\
11 \\
3 \\
3 \\
3 \\
3 \\
3 \\
\text { Apr. } 26 \\
26 \\
\text { May } 1 \\
6\end{array}$ & $\begin{array}{r}\text { Days. } \\
56 \\
52 \\
35 \\
32 \\
41 \\
49 \\
38 \\
37 \\
48 \\
53 \\
30 \\
37\end{array}$ & $\begin{array}{l}13 \ldots \\
14 \ldots \\
15 . \ldots \\
16 . . \\
17 \ldots \\
18 . \ldots \\
19 . \ldots \\
20 \ldots \\
21 \ldots \\
22 . \ldots \\
23 \ldots \\
24 . .\end{array}$ & $\begin{array}{lr}\text { Mar. } 11 \\
4 \\
13 \\
12 \\
\text { Apr. } 6 \\
\text { Mar. } 8 \\
\text { Apr. } 1 \\
1 \\
1 \\
\text { Mar. } 29 \\
9 \\
9\end{array}$ & $\begin{array}{r}\text { Apr. } 28 \\
26 \\
\text { May } 1 \\
\text { Apr. } 29 \\
\text { May } 10 \\
\text { Apr. } 28 \\
\text { May } 3 \\
3 \\
3 \\
3 \\
\text { Apr. } 28 \\
26\end{array}$ & $\begin{array}{r}\text { Days. } \\
48 \\
53 \\
49 \\
48 \\
34 \\
51 \\
32 \\
32 \\
32 \\
35 \\
50 \\
48\end{array}$ & $\begin{array}{l}25 \ldots \ldots \\
26 \ldots \ldots \\
27 \ldots \ldots \\
28 \ldots \\
29 \ldots \\
30 \ldots . \\
31 \ldots . \\
\end{array}$ & $\begin{array}{r}\text { Mar. } 9 \\
24 \\
24 \\
29 \\
\text { Apr. } 1 \\
12 \\
12 \\
\\
\text { rerage.... } \\
\text { aximum. } \\
\text { inimum. }\end{array}$ & $\begin{array}{r}\text { Apr. } 28 \\
28 \\
28 \\
28 \\
\text { May } 3 \\
4 \\
17\end{array}$ & $\begin{array}{r}\text { Days. } \\
50 \\
35 \\
35 \\
30 \\
32 \\
22 \\
35 \\
40.61 \\
56.00 \\
22.00\end{array}$ \\
\hline
\end{tabular}




\section{SPRING BROOD OF MOTHS.}

It is probable that the first adult appeared in 1909 about March 23. On this date an apparently freshly shed pupal skin was found, and another was found in the field on March 27. Bartlett pears were at this time just about in full bloom. The first moths were seen in the field on A pril 17. During spraying operations in a pear orchard three active moths were seen in the trees in the early forenoon. Others were seen on April 19, and on May 5 several were observed among trees in the corner of the orchard near the packing shed. The first moth appeared at the laboratory on April 9 from the lot of pupæ collected in the field March 11 to 22. These pupæ were kept in glass jars out of doors, but some were injured, and only three moths emerged, namely, on April 9,13 , and 14. The individual records show moths emerging from April 17 to May 30 (detailed in Tables I, II, and III). This material was kept in jars out of doors in the shade.

On May 6, 1909, several bands which had been on trees over winter were removed, and these, as also the trunks of the trees, examined closely. Thirty-six shed pupal skins were found, but no larvæ or pupa, indicating that most of the moths had emerged by this time.

In the spring of 1910 moths emerged in numbers somewhat earlier than in 1909. Individuals were seen in the orchard April 9, during spraying, although no moths emerged at the laboratory until April 14. At Suisun, Cal., April 5, while examining the trunks of trees for the presence of larvæ and pupæ, many apparently freshly shed pupal skins were found on the bark. The next day, April 6, at Courtland, Sacramento County, Cal., shed pupal skins were even more apparent in comparison with the number of larvæ and pupæ found on the trees. At this time in the two last-mentioned places the petals had been off the trees for some days, and it is generally conceded that these sections are a week or ten days earlier than in the vicinity of Walnut Creek. Table IV shows the emergence of moths from overwintering larvæ at Walnut Creek, Cal., 1909-10.

TABLE IV.-Emergence of moths from overwintering larvæ, Walnut Creek, Cal., 1909 and 1910.

\begin{tabular}{|c|c|c|c|c|c|c|c|c|c|c|c|c|c|c|c|}
\hline \multirow{2}{*}{\multicolumn{2}{|c|}{ Date. }} & \multicolumn{2}{|c|}{$\begin{array}{l}\text { Number of } \\
\text { moths } \\
\text { emerging- }\end{array}$} & \multirow{2}{*}{\multicolumn{2}{|c|}{ Date. }} & \multicolumn{2}{|c|}{$\begin{array}{l}\text { Number of } \\
\text { moths } \\
\text { emerging- }\end{array}$} & \multirow{2}{*}{\multicolumn{2}{|c|}{ Date. }} & \multicolumn{2}{|c|}{$\begin{array}{l}\text { Number of } \\
\text { moths } \\
\text { emerging- }\end{array}$} & \multirow{2}{*}{\multicolumn{2}{|c|}{ Date. }} & \multicolumn{2}{|c|}{$\begin{array}{l}\text { Number of } \\
\text { moths } \\
\text { emerging- }\end{array}$} \\
\hline & & 1909 & 1910 & & & 1909 & 1910 & & & 1909 & 1910 & & & 1909 & 1910 \\
\hline Apr. & $\begin{array}{l}14 \ldots \\
15 \ldots \\
16 \ldots \\
17 \ldots \\
18 \ldots \\
19 \ldots \\
20 \ldots \\
21 \ldots \\
22 \ldots \\
23 \ldots \\
24 \ldots \\
25 \ldots\end{array}$ & $\begin{array}{l}0 \\
0 \\
0 \\
0 \\
0 \\
0 \\
2 \\
1 \\
1 \\
0 \\
1 \\
0\end{array}$ & $\begin{array}{r}2 \\
1 \\
9 \\
9 \\
10 \\
1 \\
9 \\
7 \\
11 \\
5 \\
9 \\
0\end{array}$ & Apr. & $\begin{array}{l}26 . \\
27 . \\
28 . \\
29 . \\
30 . \\
1 . \\
2 . \\
3 . \\
4 . \\
5 . \\
6 . \\
7 .\end{array}$ & $\begin{array}{l}0 \\
1 \\
0 \\
0 \\
0 \\
2 \\
3 \\
1 \\
4 \\
4 \\
6 \\
5\end{array}$ & $\begin{array}{l}5 \\
3 \\
3 \\
1 \\
8 \\
0 \\
3 \\
4 \\
1 \\
1 \\
5 \\
3\end{array}$ & May & $\begin{array}{c}8 \ldots \\
9 \ldots \\
10 \ldots \\
11 \ldots \\
12 \ldots \\
13 \ldots \\
14 \ldots \\
15 \ldots \\
16 \ldots \\
17 \ldots \\
18 \ldots \\
19 .\end{array}$ & $\begin{array}{l}1 \\
5 \\
3 \\
2 \\
1 \\
2 \\
1 \\
0 \\
0 \\
4 \\
0 \\
1\end{array}$ & $\begin{array}{l}0 \\
2 \\
1 \\
1 \\
1 \\
0 \\
1 \\
0 \\
0 \\
0 \\
0 \\
0\end{array}$ & May & $\begin{array}{l}20 \ldots \\
21 \ldots \\
22 \ldots \\
23 \ldots \\
24 \ldots \\
25 \ldots \\
26 \ldots \\
27 \ldots \\
28 \ldots \\
29 . \\
50 \ldots \\
31 \ldots\end{array}$ & $\begin{array}{l}1 \\
0 \\
1 \\
0 \\
2 \\
2 \\
3 \\
1 \\
2 \\
2 \\
2 \\
0\end{array}$ & $\begin{array}{l}0 \\
0 \\
0 \\
0 \\
0 \\
0 \\
0 \\
0 \\
0 \\
0 \\
0 \\
0\end{array}$ \\
\hline
\end{tabular}


Table $T$ gires the emergence of moths from a quantity of overwintering material kept at San Jose, Cal. The emergence record is shown graphically in figure 6 .

TABLE T.-Emergence of moths of the spring brood, San Jose, Cal., 1909, from overwintering larvæ collected on banded apple trees.

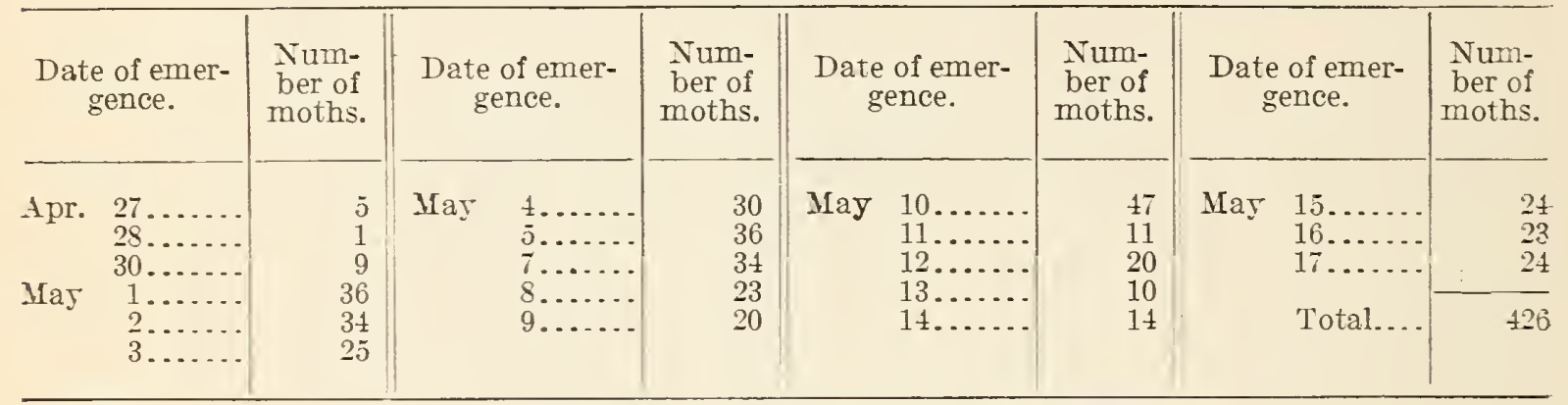

THE FIRST GENERATION.

FIRST-BROOD EGGS.

Time of oriposition. - No eggs were laid in breeding cages in 1909 until May $\boldsymbol{7}$, but numerous eggs were found in the orchard on May 5 ,

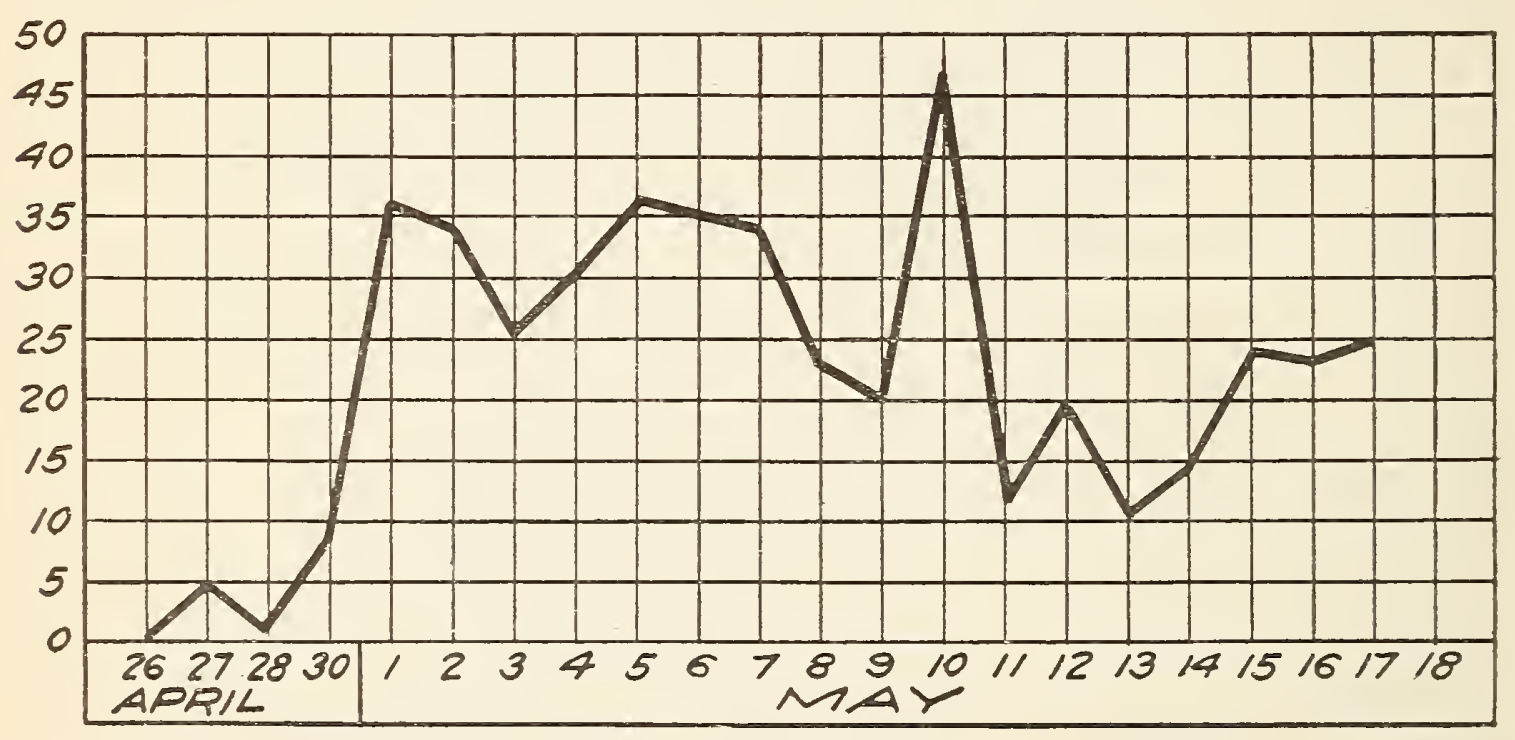

Fi IG. 6. Weekly emergence of codling moths from orerwintered material at San Jose, Cal., 1909. (Original.)

18 of which were collected, mostly showing black heads of larræ. These were carried to the laboratory and kept out of doors, the first hatching Way 7; 14 more had hatched by May 15; the others failed to hatch. On May 11 eggs were numerous on the fruit and foliage in the field, and 8 recently hatched larvæ were found on two trees near the packing shed. As the average period of incubation was about 21 days at this time, the approximate date for first oriposition in the field would be April 15. Since practically all moths in the field had emerged by May 6, it is not probable that any eggs were deposited in the field after May 15. The last eggs were secured in cages at the laboratory on May 12. Although many moths emerged after this date in the glass jars, very few were alive at any one time.

Corresponding with the time of emergence of moths, eggs were deposited earlier in 1910 than was the case in 1909. On April 25 at, 
Walnut Creek, three eggs were found on foliage in the field, and on May 2 eggs were numerous throughout the valley. At Suisun, Cal., larvæ were hatching April 29, and on May 3 young larvæ were quite numerous in some of the warmer sections of Suisun Valley, indicating that eggs were deposited in numbers some two to three weeks before, that is, from the 12th to the 20th of April.

Incubation period. - One noticeable difference between the life history of the codling moth in California and in the country east of the Rocky Mountains is the increased length of time required for incubation of the first-brood eggs. As a rule there is considerable cool weather, especially at night, during the months of April and May. This was especially noticeable in the vicinity of Walnut Creek in 1909. The time required for incubation varied from 17 to 22 days, averaging 20.05 days for the individuals under observation. The individual record for 56 eggs, deposited from May 8 to 11, are given in Table TI.

In the spring of 1910 the period of incubation was not observed individually for many eggs, but all indications were that the incubation period varied from a minimum of 15 days to a maxinum of over 30 days, with the majority requiring about 25 days.

Table VI.-Life cycle of the first generation, Walnut Creek, Cal., 1909.

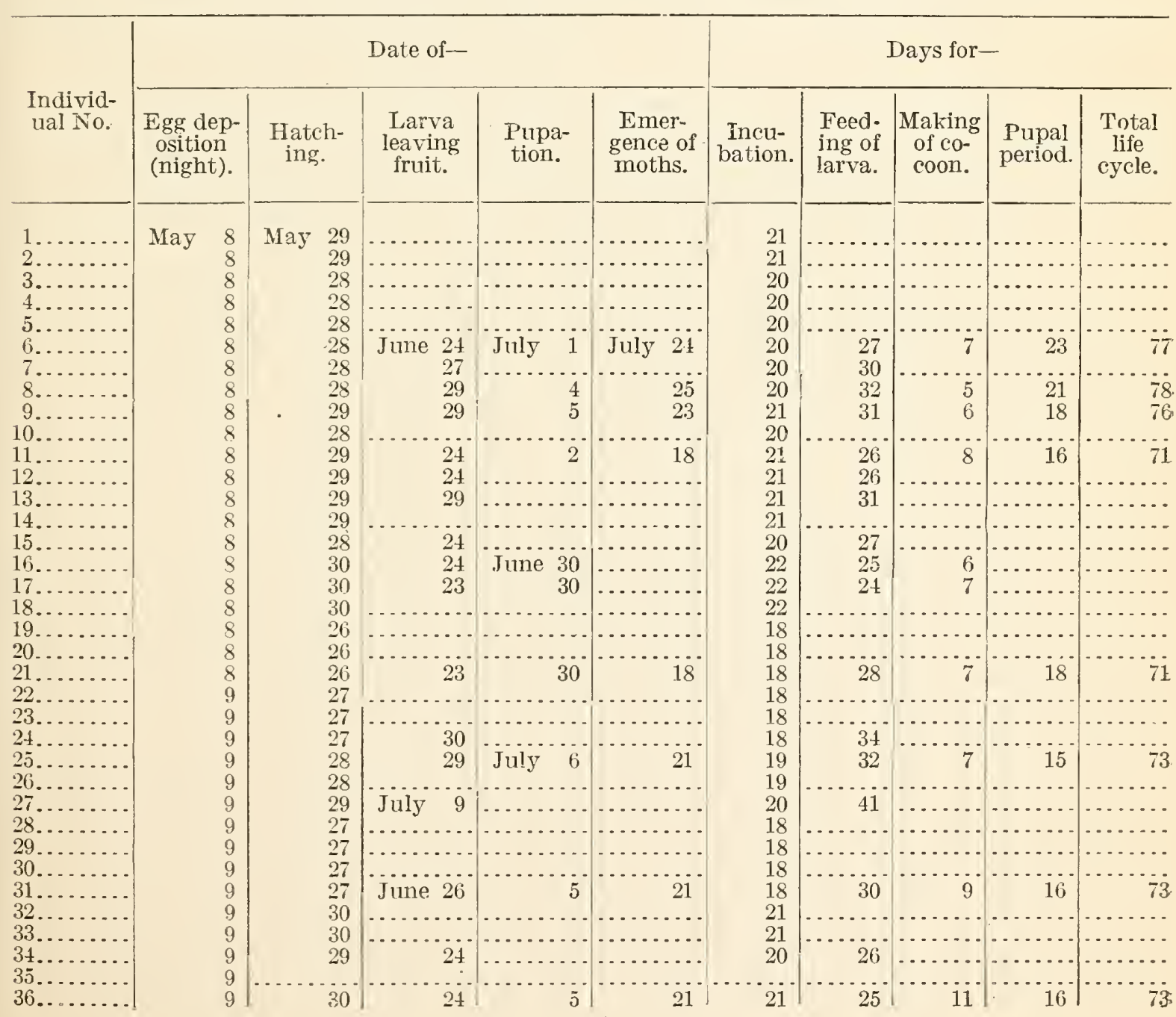


TABLE VI.-Life cycle of the first generation, Walnut Creek, Cal., 1909-Continued.

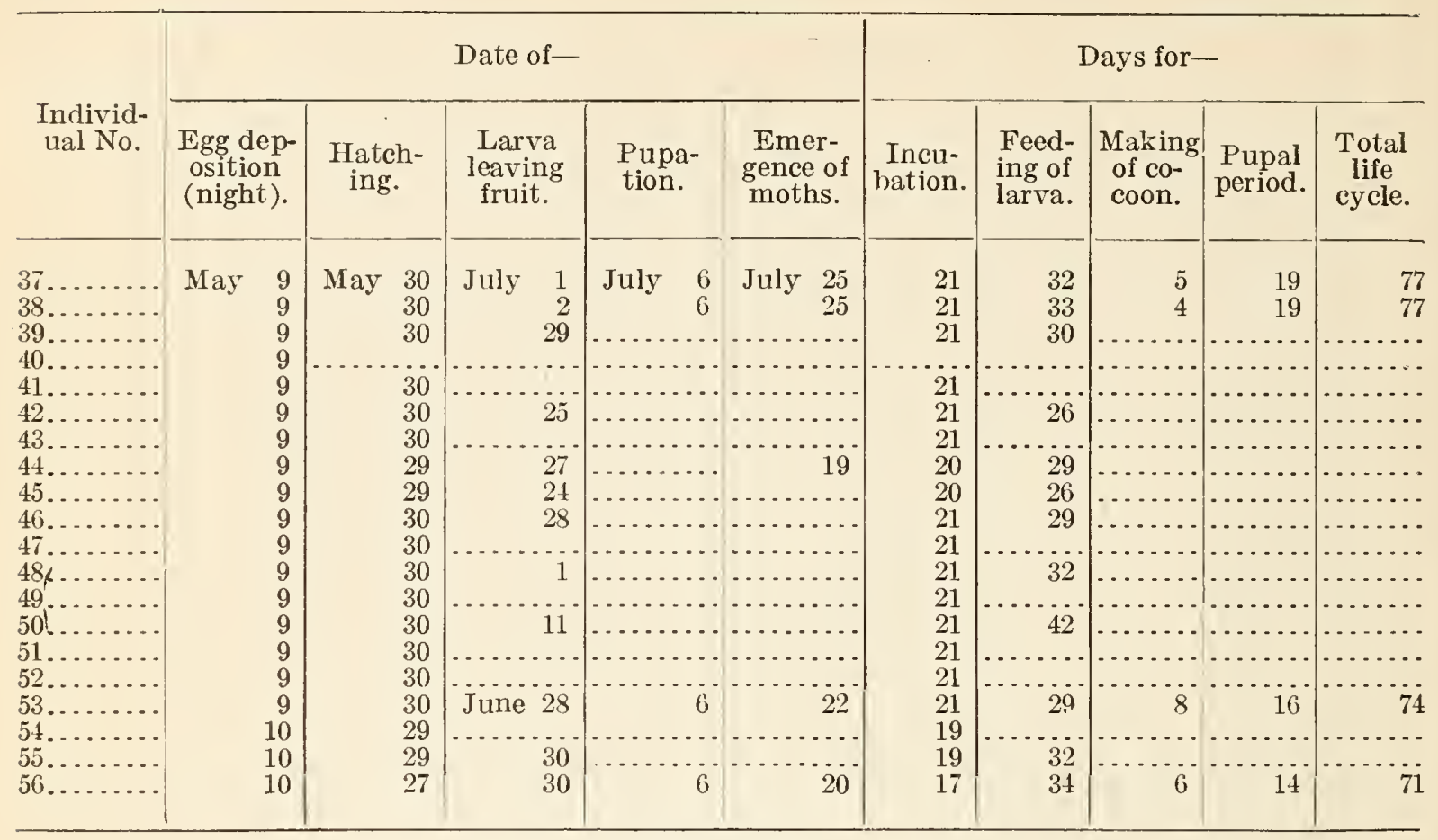

SUMMARY.

\begin{tabular}{|c|c|c|c|c|c|}
\hline \multirow[b]{2}{*}{ Observations. } & \multicolumn{5}{|c|}{ Days for-- } \\
\hline & $\begin{array}{l}\text { Incuba- } \\
\text { tion. }\end{array}$ & $\begin{array}{c}\text { Feeding } \\
\text { of } \\
\text { larva. }\end{array}$ & $\begin{array}{l}\text { Making } \\
\text { of } \\
\text { cocoon. }\end{array}$ & $\begin{array}{l}\text { Pupal } \\
\text { period. }\end{array}$ & $\begin{array}{c}\text { Total life } \\
\text { cycle. }\end{array}$ \\
\hline $\begin{array}{l}\text { Average.... } \\
\text { Maximum. } \\
\text { Minimum. }\end{array}$ & $\begin{array}{l}20.05 \\
22.00 \\
17.00\end{array}$ & $\begin{array}{l}29.97 \\
42.00 \\
24.00\end{array}$ & $\begin{array}{r}6.85 \\
11.00 \\
4.00\end{array}$ & $\begin{array}{l}17.58 \\
23.00 \\
14.00\end{array}$ & $\begin{array}{l}74.25 \\
78.00 \\
71.00\end{array}$ \\
\hline
\end{tabular}

FIRST-BROOD LARV无.

Time of hatching.-The first larvæ under observation in 1909 hatched May 7 from eggs brought in from the field. On May 11, 8 recently hatched larvæ were found in the orchard. On this same date, May 11, 1910, young larvæ were quite numerous in the field. At Suisun, Cal., in 1910, the first larva was found April 29, and recently hatched larvæ were quite numerous by May 3. Very young larvæ were found continuously until the 1st of June. Larvæ at laboratory hatched May 26 to 30 , and it is very likely that all first-brood eggs in the field had hatched and all larvæ were in fruit by this time.

Development of larvæ in fruit.-Of the larvæ hatching under observation in 1909, only 29 reached full development in the fruit, requiring from 25 to 42 days. The individual records are given in Table VI. The first larva to leave the fruit in the field was not observed, but on June 5 three newly formed pupæ and 20 full-grown larvæ were found under bands on 21 pear trees, and 4 pupæ and 28 
full-grown larvæ were found under bands on 10 apple trees. The time from leaving fruit to pupation for this brood, averaging $7 \frac{1}{4}$ days, would indicate that the first full-grown larvæ left fruit in late May. Band records and data obtained by bringing in quantities of wormy fruit picked from trees in May showed a maximum number of firstbrood larvæ leaving fruit June 14 to 26 . However, later-maturing larvæ of this brood left fruit as late as July 21.

In the summer of 1910 many full-grown larvæ had left the fruit prior to the 1st of June. At Walnut Creek cin June 1, 4 pupæ and 248 larvæ were taken from the bands on 11 apple trees, and at Suisun on June 3, 10 pupæ and 45 larvæ were taken from bands on 15 pear trees.

Larval life in cocoon. - The time spent from leaving fruit to pupating varied from 3 to 23 days, with an average of $7 \frac{1}{4}$ days. These records were made from 165 larvæ which left fruit from June 7 to July 21 and kept in large shell vials out-of-doors. The records for 110 individuals will be seen in Table VII. All larvæ were put in vials with bits of paper and cloth, and the vials turned upside down on a glass plate for a few days. The larvæ usually "cocooned" within 24 hours after leaving the fruit and the records show the normal time. After the cocoon had been made the vials were placed open end up and covered with cheesecloth.

FIRST-BROOD PUPA.

Time of pupation.-The first pupæ were found in the field June 5, 1909, when a total of 7 were taken with 49 larvæ under bands from 21 pear and 10 apple trees. In 1910 pupæ were found June 1 and were plentiful in the vicinity of Suisun and Walnut Creek by June 5. At the laboratory the first larva pupated June 12, which had left fruit on June 7 . The maximum number of pupæ from material collected under bands and larvæ leaving fruit at the laboratory occurred from June 20 to 30.

Length of pupal period.-Records kept out-of-doors for 165 individuals gave a minimum of 10 days and a maximum of 27 days with an average of $16 \frac{1}{2}$ days for the time spent in the pupal stage. The records for 110 individuals will be found in Table VII.

The total time from leaving fruit to the emergence of adults varied from 20 to 47 days, averaging 25.69 days for the individuals under observation.

$71419^{\circ}-$ Bull. $97-12-3$ 
TABLE VII.-Length of time as larva in cocoon, length of pupal stage, and total time spent from leaving fruit to emergence of adult, Walnut Creek, Cal., 1909.

\begin{tabular}{|c|c|c|c|c|c|c|}
\hline \multirow[b]{2}{*}{ Individual No. } & \multicolumn{3}{|c|}{ Date of- } & \multicolumn{3}{|c|}{ Days fer-- } \\
\hline & $\begin{array}{l}\text { Larra } \\
\text { learing } \\
\text { the fruit. }\end{array}$ & $\begin{array}{l}\text { Pupa- } \\
\text { tion. }\end{array}$ & $\begin{array}{l}\text { Emer- } \\
\text { gence of } \\
\text { moth. }\end{array}$ & $\begin{array}{l}\text { Making } \\
\text { of cocoon }\end{array}$ & $\begin{array}{l}\text { Pupal } \\
\text { period. }\end{array}$ & $\begin{array}{l}\text { Total } \\
\text { period in } \\
\text { cocoon. }\end{array}$ \\
\hline $1 \ldots$ & June 7 & & July 11 & & & 34 \\
\hline $2 \ldots$ & & June 14 & & 6 & 20 & 26 \\
\hline 3... & 9 & 17 & 6 & 8 & 19 & 27 \\
\hline $4 \ldots . .$. & 9 & 20 & 8 & 11 & 18 & 29 \\
\hline $5 \ldots . .$. & 10 & 14 & 4 & 4 & 20 & 24 \\
\hline ........... & 11 & 14 & 6 & 3 & 22 & 25 \\
\hline$\ldots$ & 12 & …..... & 29 & ii & 19 & $\begin{array}{l}47 \\
30\end{array}$ \\
\hline 9 & 10 & 22 & 11 & 12 & $\begin{array}{l}19 \\
19\end{array}$ & $\begin{array}{l}30 \\
31\end{array}$ \\
\hline $10 \ldots \ldots$ & 10 & 15 & 7 & 5 & 22 & $\begin{array}{l}31 \\
27\end{array}$ \\
\hline $11 \ldots .$. & 10 & 19 & 5 & 9 & 16 & 25 \\
\hline$\ldots \ldots \ldots \ldots$ & 10 & 20 & 7 & 10 & 17 & 27 \\
\hline .............. & 10 & 17 & 5 & 7 & 18 & 25 \\
\hline . & 11 & 24 & 17 & 13 & 23 & 36 \\
\hline (n) & 11 & 23 & 10 & 12 & 17 & 29 \\
\hline$\ldots \ldots . . .6$ & 11 & 20 & 8 & 9 & 18 & 27 \\
\hline $\begin{array}{l}17 \ldots \ldots \ldots \ldots \\
18 \ldots \ldots \ldots\end{array}$ & $\begin{array}{l}11 \\
11\end{array}$ & $\dddot{21}^{\circ}$ & $\begin{array}{r}20 \\
8\end{array}$ & $\dddot{10}$ & 17 & 39 \\
\hline $19 \ldots \ldots$ & 12 & 20 & 6 & 8 & 16 & $\begin{array}{l}27 \\
24\end{array}$ \\
\hline$\ldots \ldots \ldots \ldots$ & 12 & 20 & 8 & 8 & 18 & 26 \\
\hline (n) & 12 & 23 & 8 & 11 & 15 & 26 \\
\hline ........ & 12 & 20 & 7 & 8 & 17 & 25 \\
\hline (n........ & 12 & 15 & 4 & 3 & 19 & 22 \\
\hline ............ & 12 & 23 & 8 & 11 & 15 & 26 \\
\hline 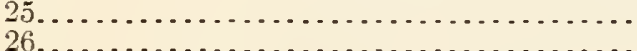 & & $\cdots$ & 20 & & & 3 \\
\hline (1, & 12 & 20 & $\underline{7}$ & 8 & 17 & 25 \\
\hline $28 \ldots \ldots \ldots \ldots$ & $\begin{array}{l}12 \\
12\end{array}$ & 21 & $\frac{7}{5}$ & 9 & 16 & 25 \\
\hline $29 \ldots \ldots \ldots$ & 12 & 21 & 11 & 8 & 17 & 25 \\
\hline $30 \ldots \ldots$ & 12 & 19 & $\begin{array}{r}11 \\
6\end{array}$ & 9 & 20 & \\
\hline 31. & 12 & 16 & $\frac{0}{7}$ & $\begin{array}{l}3 \\
4\end{array}$ & 17 & 24 \\
\hline 32. & 12 & 22 & $i$ & 10 & $\begin{array}{l}21 \\
15\end{array}$ & $\begin{array}{l}25 \\
25\end{array}$ \\
\hline 33. & 12 & 19 & 5 & 7 & 16 & 23 \\
\hline $34 \ldots$ & 12 & 20 & 6 & & 16 & 24 \\
\hline . . . . . & 12 & 20 & 6 & & 16 & 24 \\
\hline ........ & 12 & 21 & 8 & 9 & 17 & 26 \\
\hline ........ & 12 & 19 & 5 & 7 & 16 & 23 \\
\hline$\ldots \ldots$. & 12 & 21 & 7 & 9 & 16 & 25 \\
\hline ........ & 12 & 20 & 6 & 8 & 16 & 24 \\
\hline 40 & 12 & 18 & 5 & 6 & 17 & 23 \\
\hline ....... & 12 & 20 & 6 & 8 & 16 & 24 \\
\hline ........... & 12 & 20 & 7 & 8 & 17 & 25 \\
\hline ........ & 12 & 21 & 7 & 9 & 16 & 25 \\
\hline$\ldots . .$. & 12 & 20 & 7 & 8 & 17 & 25 \\
\hline 45. & 11 & 16 & 4 & 5 & 18 & 23 \\
\hline . . . . . & 11 & July 4 & 19 & 23 & 15 & 38 \\
\hline 47. & 11 & June 19 & 5 & 8 & 16 & 24 \\
\hline ........ & 11 & 21 & 11 & 10 & 20 & 30 \\
\hline ........ & 11 & 20 & 7 & 9 & 17 & 26 \\
\hline$\ldots \ldots \ldots$. & 11 & 20 & 6 & 9 & 16 & 25 \\
\hline ......... & 11 & 20 & 6 & 9 & 16 & 25 \\
\hline$\ldots \ldots . . . .$. & 11 & 21 & 7 & 10 & 16 & 26 \\
\hline 53. & 14 & 23 & 11 & 9 & 18 & 27 \\
\hline $54 .$. & 14 & 22 & 11 & 8 & 19 & 27 \\
\hline$\ldots$ & 14 & 24 & 11 & 10 & 17 & 27 \\
\hline$\ldots \ldots \ldots$. & 14 & 24 & 11 & 10 & 17 & 27 \\
\hline$\ldots, \ldots, \ldots$ & & 24 & 11 & 10 & 17 & 27 \\
\hline ............ & & 23 & & 8 & 18 & 26 \\
\hline$\ldots \ldots \ldots \ldots \ldots$ & 15 & 26 & 19 & 11 & 23 & 34 \\
\hline (1) & $\begin{array}{l}15 \\
15\end{array}$ & $\begin{array}{l}24 \\
24\end{array}$ & $\begin{array}{l}11 \\
11\end{array}$ & $\begin{array}{l}9 \\
9\end{array}$ & $\begin{array}{l}17 \\
17\end{array}$ & $\begin{array}{l}26 \\
26\end{array}$ \\
\hline $\begin{array}{l}61 . . \\
62 . .\end{array}$ & 15 & 24 & 10 & 9 & 16 & $\begin{array}{l}26 \\
25\end{array}$ \\
\hline & 16 & 23 & 10 & 7 & 17 & 24 \\
\hline …........ & 16 & 24 & 12 & 8 & 18 & 26 \\
\hline (n............. & 17 & 24 & 12 & 7 & 18 & 25 \\
\hline 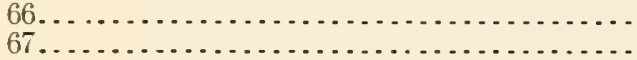 & $\begin{array}{l}18 \\
20\end{array}$ & $\begin{array}{l}26 \\
27\end{array}$ & $\begin{array}{l}23 \\
13\end{array}$ & $\frac{8}{7}$ & $\begin{array}{l}27 \\
16\end{array}$ & $\begin{array}{l}35 \\
23\end{array}$ \\
\hline ................ & 20 & 24 & 12 & 4 & 18 & 22 \\
\hline , & 20 & $\begin{array}{l}30 \\
28\end{array}$ & 20 & 10 & 20 & 30 \\
\hline (n, & $\begin{array}{l}20 \\
20\end{array}$ & $\begin{array}{l}28 \\
24\end{array}$ & $\begin{array}{l}16 \\
16\end{array}$ & $\begin{array}{l}8 \\
4\end{array}$ & $\begin{array}{l}18 \\
22\end{array}$ & $\begin{array}{l}26 \\
26\end{array}$ \\
\hline ........... & 20 & 23 & 10 & 3 & 17 & 20 \\
\hline 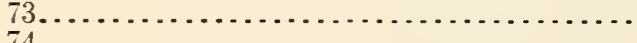 & 20 & 23 & 11 & 3 & 18 & 21 \\
\hline 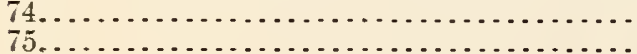 & $\begin{array}{l}20 \\
20\end{array}$ & $\begin{array}{l}24 \\
24\end{array}$ & $\begin{array}{l}10 \\
12\end{array}$ & $\begin{array}{l}4 \\
4\end{array}$ & 16 & 20 \\
\hline ….... & 20 & 28 & 11 & $\begin{array}{l}4 \\
8\end{array}$ & $\begin{array}{l}10 \\
13\end{array}$ & 21 \\
\hline & 20 & 26 & 11 & 6 & 15 & 21 \\
\hline & 17 & 23 & 11 & 6 & 18 & 24 \\
\hline
\end{tabular}


TABLE VII.-Length of time as larva in cocoon, length of pupal stage, and total time spent from leaving fruit to emergence of adult, Walnut Creek, Cal.-Continued.

\begin{tabular}{|c|c|c|c|c|c|c|}
\hline \multirow[b]{2}{*}{ Individual No. } & \multicolumn{3}{|c|}{ Date of- } & \multicolumn{3}{|c|}{ Days for- } \\
\hline & $\begin{array}{c}\text { Larva } \\
\text { leaving } \\
\text { the fruit. }\end{array}$ & $\begin{array}{l}\text { Pupa- } \\
\text { tion. }\end{array}$ & $\begin{array}{l}\text { Emer- } \\
\text { gence of } \\
\text { moth. }\end{array}$ & $\begin{array}{l}\text { Making } \\
\text { of cocoon. }\end{array}$ & $\begin{array}{l}\text { Pupal } \\
\text { period. }\end{array}$ & $\begin{array}{l}\text { Total } \\
\text { period in } \\
\text { cocoon. }\end{array}$ \\
\hline 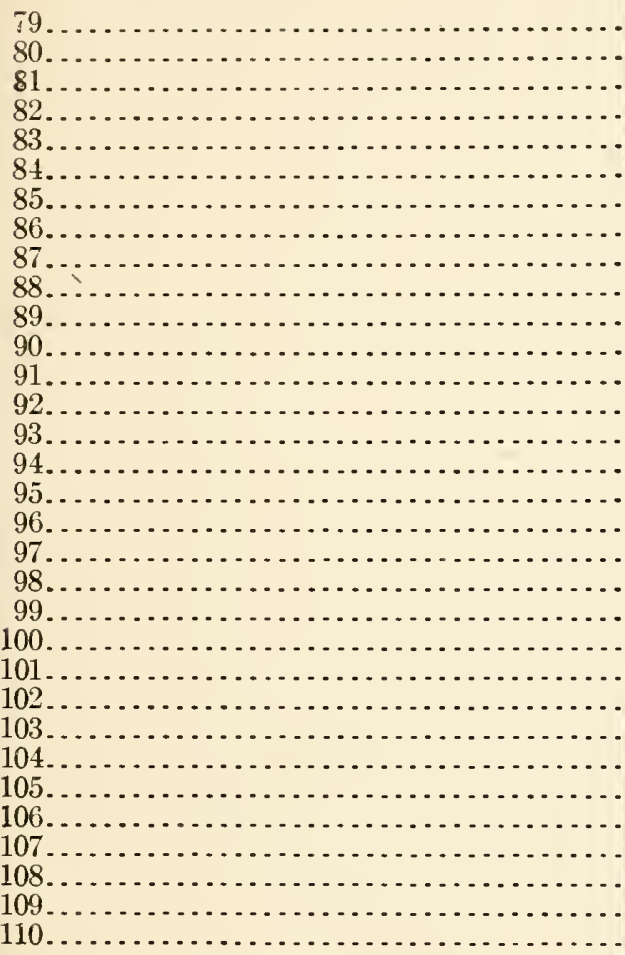 & $\begin{array}{r}\text { June } 18 \\
19 \\
19 \\
19 \\
19 \\
19 \\
21 \\
21 \\
21 \\
21 \\
21 \\
21 \\
21 \\
21 \\
21 \\
21 \\
24 \\
24 \\
24 \\
24 \\
24 \\
24 \\
24 \\
24 \\
24 \\
24 \\
26 \\
26 \\
26 \\
26 \\
26 \\
26\end{array}$ & $\begin{array}{r}\text { June } 24 \\
24 \\
27 \\
24 \\
24 \\
29 \\
29 \\
29 \\
29 \\
30 \\
28 \\
29 \\
29 \\
28 \\
29 \\
29 \\
29 \\
29 \\
30 \\
30 \\
39 \\
29 \\
30 \\
1 \\
\text { July } \\
2 \\
2 \\
2 \\
2 \\
2 \\
3 \\
1 \\
1 \\
1 \\
2 \\
4 \\
2\end{array}$ & $\begin{array}{cc}\text { July } & 13 \\
11 \\
13 \\
10 \\
10 \\
13 \\
13 \\
13 \\
15 \\
13 \\
13 \\
20 \\
13 \\
16 \\
12 \\
12 \\
29 \\
21 \\
21 \\
20 \\
16 \\
16 \\
18 \\
16 \\
16 \\
20 \\
20 \\
16 \\
16 \\
21 \\
21 \\
22\end{array}$ & $\begin{array}{r}6 \\
5 \\
8 \\
5 \\
5 \\
10 \\
8 \\
8 \\
9 \\
7 \\
8 \\
8 \\
7 \\
8 \\
8 \\
8 \\
5 \\
6 \\
6 \\
5 \\
6 \\
8 \\
8 \\
8 \\
8 \\
5 \\
5 \\
6 \\
8 \\
6\end{array}$ & $\begin{array}{l}19 \\
17 \\
16 \\
16 \\
16 \\
14 \\
14 \\
14 \\
15 \\
15 \\
14 \\
21 \\
15 \\
17 \\
13 \\
13 \\
30 \\
21 \\
21 \\
21 \\
16 \\
15 \\
16 \\
14 \\
14 \\
18 \\
17 \\
15 \\
15 \\
19 \\
17 \\
20\end{array}$ & $\begin{array}{l}25 \\
22 \\
24 \\
21 \\
21 \\
24 \\
22 \\
22 \\
24 \\
22 \\
22 \\
29 \\
25 \\
25 \\
21 \\
21 \\
35 \\
27 \\
27 \\
26 \\
22 \\
22 \\
24 \\
22 \\
22 \\
26 \\
24 \\
20 \\
20 \\
25 \\
25 \\
26\end{array}$ \\
\hline
\end{tabular}

Total period from leaving of fruit by larva to emergence of moth:

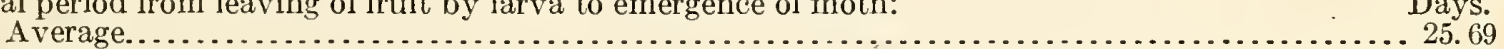

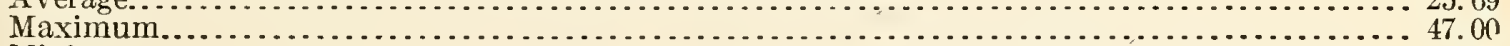
Minimum.

SUMMARY.

\begin{tabular}{|c|c|c|c|c|c|c|c|}
\hline $\begin{array}{c}\text { Length of } \\
\text { time larvæ } \\
\text { and pupæe } \\
\text { remain in } \\
\text { cocoon. }\end{array}$ & $\begin{array}{l}\text { No. of } \\
\text { indi- } \\
\text { viduals. }\end{array}$ & $\begin{array}{l}\text { Length of } \\
\text { time larvæ } \\
\text { and pupæ } \\
\text { remain in } \\
\text { cocoon. }\end{array}$ & $\begin{array}{l}\text { No. of } \\
\text { indi- } \\
\text { viduals. }\end{array}$ & $\begin{array}{l}\text { Length of } \\
\text { time larvæ } \\
\text { and pupæ } \\
\text { remain in } \\
\text { cocoon. }\end{array}$ & $\begin{array}{l}\text { No. of } \\
\text { indi- } \\
\text { viduals. }\end{array}$ & $\begin{array}{l}\text { Length of } \\
\text { time larvæ } \\
\text { and pupæ } \\
\text { remain in } \\
\text { cocoon. }\end{array}$ & $\begin{array}{l}\text { No. of } \\
\text { indi- } \\
\text { viduals. }\end{array}$ \\
\hline $\begin{array}{r}\text { Days. } \\
20 \\
21 \\
22 \\
23 \\
24\end{array}$ & $\begin{array}{r}2 \\
9 \\
13 \\
5 \\
15\end{array}$ & $\begin{array}{r}\text { Days. } \\
25 \\
26 \\
27 \\
29\end{array}$ & $\begin{array}{r}21 \\
16 \\
12 \\
4\end{array}$ & $\begin{array}{r}\text { Days. } \\
30 \\
31 \\
34 \\
35\end{array}$ & $\begin{array}{l}3 \\
1 \\
2 \\
2\end{array}$ & $\begin{array}{r}\text { Days. } \\
36 \\
38 \\
39 \\
47\end{array}$ & $\begin{array}{l}1 \\
2 \\
1 \\
1\end{array}$ \\
\hline
\end{tabular}

FIRST-BROOD MOTHS.

Moths began to emerge June 17 from larvæ and pupæ collected under bands June 5, reaching a maximum emergence some two weeks later, July 4 to 15. Eggs were plentiful on fruit and foliage of unsprayed trees July 7 , indicating that many moths were out previous to that time. The first moths from larvæ maturing in wormy fruit brought into the laboratory emerged June 22, but comparatively few emerged from this time until early July. June 28 to 30 many recently shed pupal skins were found under some old burlap bands and in cracks and crevices of bark on unsprayed trees. 
LIFE CYCLE OF THE FIRST GENERATION.

From the earliest appearing eggs in spring, about April 15, to the first appearing moths, June 17, gives some 63 days as the approximate length of the life cycle of the first generation. The laboratory records for individuals kept in breeding cages give a life cycle of 71 to 78 days. This, however, is based on only 12 individuals, which completed the cycle, and are recorded in Table VI. Careful observation indicates the length of time of the first generation to be from 60 to 70 days.

\section{THE SECOND GENERATION.}

SECOND-BROOD EGGS.

Time of oviposition. - A number of moths which emerged at the laboratory in late June and early July were put in rearing cages containing small branches of fruit and leaves and also fruit juices and sugar for food. The first eggs were deposited July 3. Some of the moths died before depositing eggs. On June 28, 1909, while looking after spraying operations in the field, frequent searches were made in the unsprayed block, but no eggs were found. During another search on July 7 among these trees many eggs were found and 5 larvæ just hatched, none of which had entered fruit, were found during the forenoon. Eggs were being deposited in large numbers in rearing cages July 8 to 10 .

Incubation period.-The time required for incubation was less than half that required for the first-brood eggs. In cages this varied from $7 \frac{1}{4}$ to $9 \frac{1}{2}$ days, and averaged $8 \frac{1}{4}$ days. The weather at this time was usually warm throughout the day with comparatively cool nights. In Table VIII are recorded incubation periods for several groups of eggs deposited between July 3 and 29. It will be noticed that eggs deposited July 10, 11, 26, and 28 required shorter time for incubation than others. Both of these periods were followed by 3 to 4 days of very warm weather.

TABLE VIII.-Incubation periods of second-brood eggs, Walnut Creek, Cal., 1909.

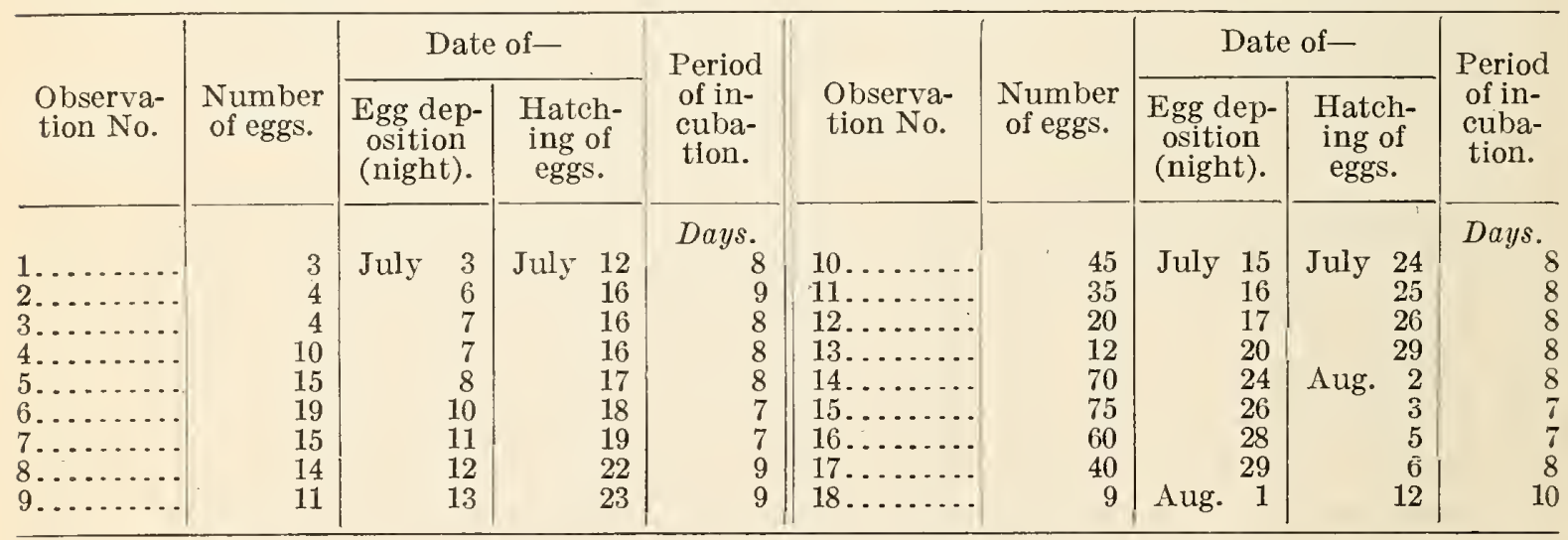


SECOND-BROOD LARVA.

Time of hatching.- July 12 was the date of first hatching of larvæ at the laboratory. These were from eggs deposited the night of July 3. As several adults had emerged and died previous to this date, it was not the actual beginning of the egg-laying period. Second-brood larvæ were hatching in numbers July 18 to 20.

On July 7 careful search in the field showed 5 very young larvæ. From July 10 to 12 second-brood larvæ were plentiful; from July 15 to 18 they were numerous, and by this time their work was showing a great deal on the unsprayed trees. Occasionally 3 and 4 entrance holes were found in a single pear.

Development of larvæ in relation to fruit.--The first picking of pears in the orchard where the spraying experiment was carried out in 1909 began July 15 and lasted 5 days. During this time young larvæ were hatching and entering the fruit in numbers in the unsprayed block, so that even the earliest first picking of fruit did not wholly escape the second-brood larvæ. In 1910 many second-brood larvæ were in the fruit before the first picking. The second and third pickings, coming later, are worse injured. The third or last picking receives practically the full force of the second-brood larvæ. In many orchards this picking will run 70 per cent wormy. The third picking of pears on the unsprayed block in 1909 showed an average of 75 per cent wormy, while in 1910 practically all of the pears left on the trees in the check blocks were wormy.

Life of larvæ in fruit.- The period covered by the life of the larvæ in the fruit was not positively determined for a very large number of second-brood larvæ. The harvesting of the fruit takes a large percentage of the larvæ to the packing shed before they reach full development.

At the laboratory several hundred individual records were started, but the quick rotting of some of the fruit during a short absence destroyed part of the records. The first larvæ left the fruit August 6,1909 , at the laboratory, but in the field comparatively few larvæ as a rule reach their full development before the fruit is all harvested, which is about the middle of August. In the summer of 1910 the first full-grown larvæ of the second brood were found at Suisun July 26, and at Walnut Creek on August 1. At this time practically all pears around Suisun and about two-thirds of the crop in the vicinity of Walnut Creek had been harvested.

Records for 63 individuals which went through in sound or nearly soured fruit out-of-doors at the laboratory in 1909 are given in Table IX. As may be seen, this gives about 26 days for the period of the larvæ in the fruit. 
TABLE IX.-Feeding periods of second-brood larvæ in pears, Walnut Creek, Cal., 1909.

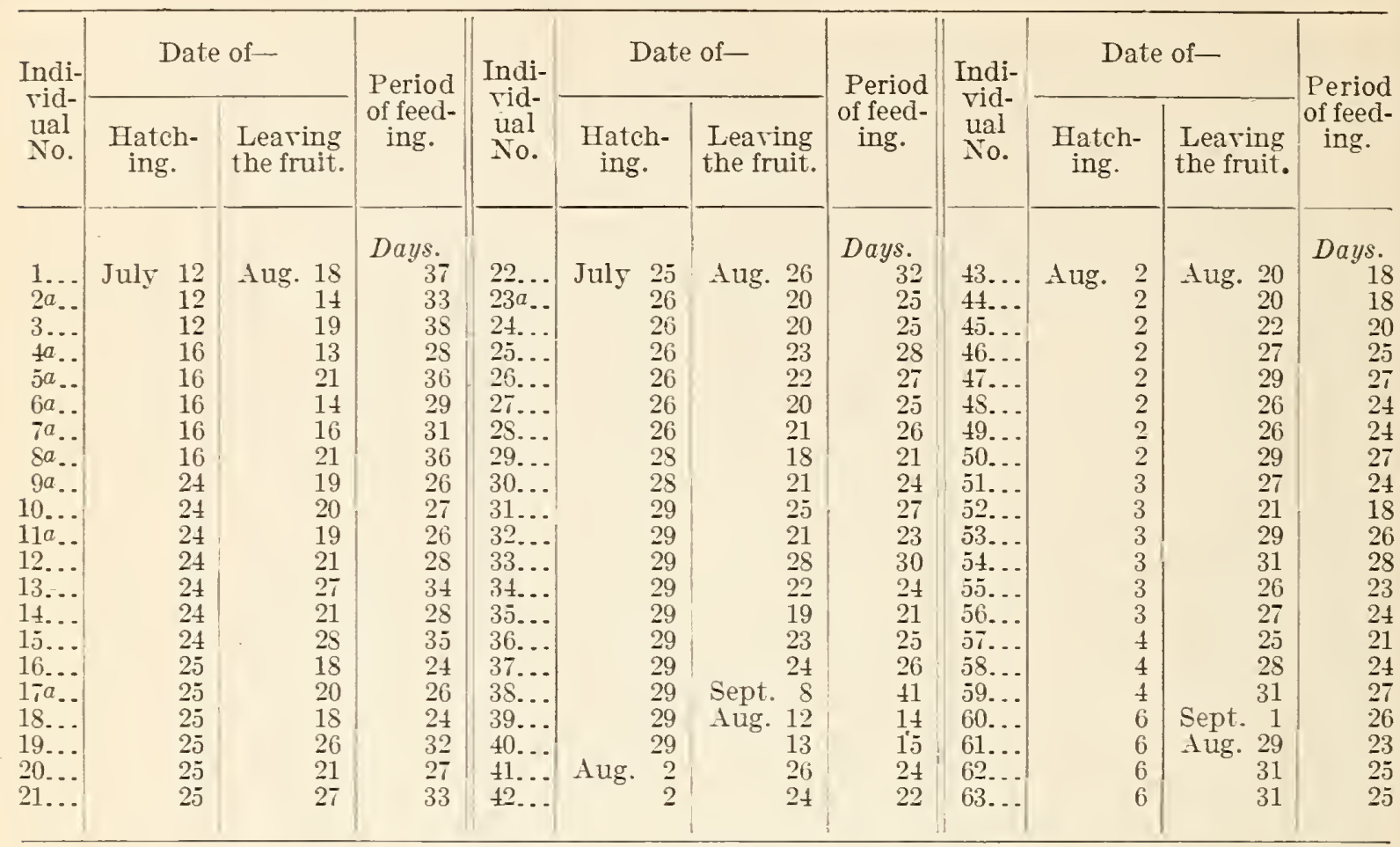

a Pupated and moth emerged in September.

Feeding period:

Arerage...

Minimum.

Dass.

26.34

41.00

Overwintering lariæ.- The first larvæ not pupating but going into winter cocoons in 1909 were taken from bands July 17. Of 78 larvæ taken on this date, 38 pupated and adults emerged, 28 died, and 20 went through the winter as larvæ. Of 196 larræ and pupæ collected under bands on June 28, 1910, 5 did not pupate but wintered as larræ in cocoons. After this date the percentage of overwintering larræ increased. However, some adults emerged as late as September 18. With the development of the second brood there was a marked increase in the number of overwintering larræ. Of some 95 to 100 larvæ developing in fruit out-of-doors at the laboratory, only 9 pupated. These were Nos. 2, 4, 6, 7, 8, 9, 11, 17, and 23 in Table IX. Adults emerged 17 to 36 days after leaving fruit. This would give some 6 to 7 weeks for the life of the individuals of the second generation.

REVIEW OF LIFE HISTORY FOR THE YEARS 1909 AND 1910.

There are practically two full broods of larvæ each year in the interior counties of California. It is not easy to distinguish definitely between the two generations by field observations alone, and to know just when all the first-brood larræ are in the fruit, although there is a period of some weeks each summer during which very few eggs are laid. Taking into consideration the difference in time required for derelopment of eggs and larræ, and the fact that the pears are picked before very many of the second-brood larvæ leave the fruit, it is difficult to determine the division of generations by band records. Some growers report that roung larvæ are hatching and entering fruit 
almost continuously from April to August, inclusive, and do not recognize the broorls at all. However, it is well to know when these broods appear, and what is meant by the term "brood."

The overwintering larvæ pupate in spring; the moths emerging from these in late April and during May deposit eggs which hatch into the firstbrood worms. This brood is usually comparatively small and the injury not severe. Some growers are inclined to overlook the importance of this brood, and many fail to notice any worms until the second brood begins to show just prior to first picking. The second is by far

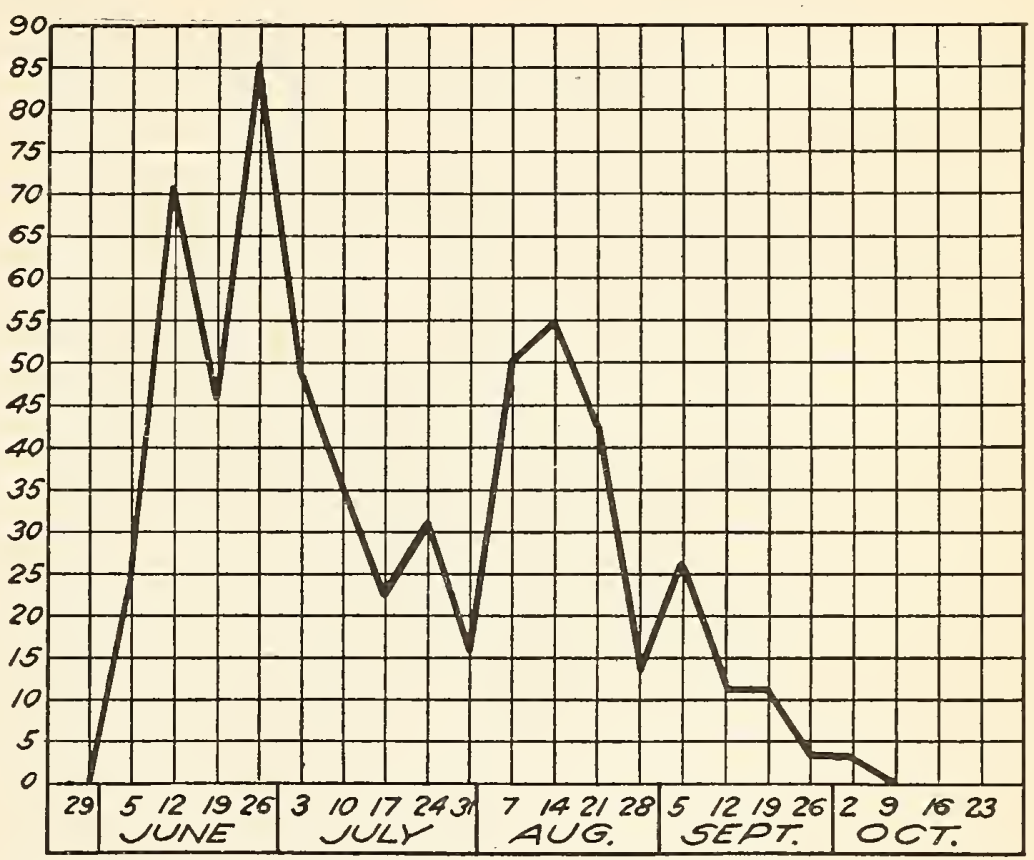

FIG. 7.-Codling-moth larvæ collected from banded pear trees at Walnut Creek, Cal., 1909. (Original.)

the more destructive of the two broods, both by reason of its numbers and because of the stage of the fruit when it appears. The first-brood worms reach their development usually during the months of May and June, pupate, and adults emerge and begin depositing eggs some one or two weeks before the first picking of pears commences. Growers can tell very well when the first of the second-brood worms will begin

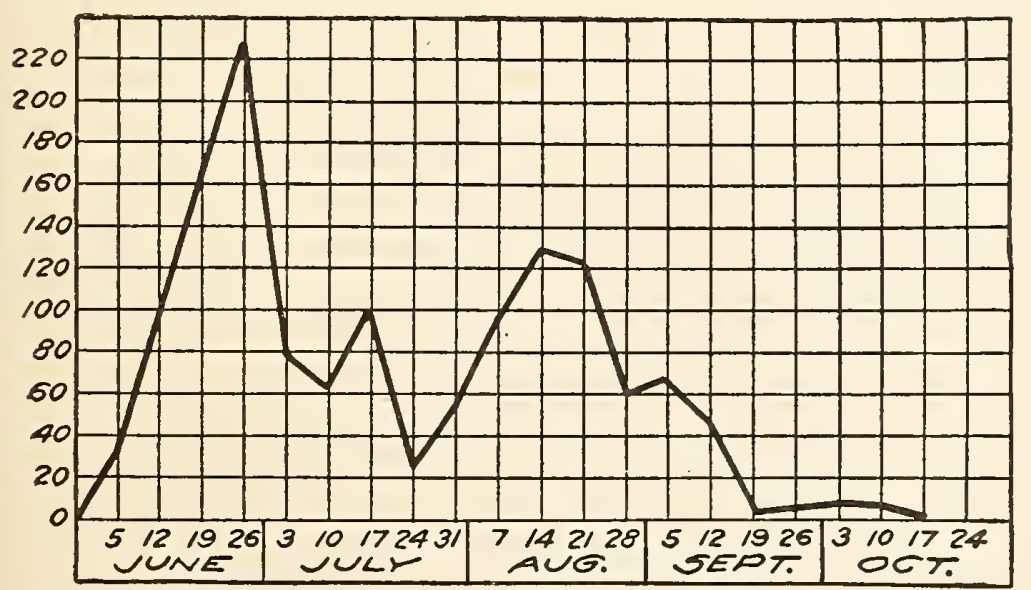

FiG. 8.-Codling-moth larvæ collected from banded apple trees at Walnut Creek, Cal., 1909. (Original.)

to appear by the use of burlap bands put on the trees in May. Examine these once a week and when the first larvæ are caught under them they may be put into glass jars or tumblers with bits of paper or rags and kept under normal out-of-doors condi-

tions. When the first moths appear it will then be some two weeks before eggs are hatching.

BAND RECORDS.

Some idea of the development of the first-brood larvæ and the time of leaving fruit may be gained from Tables $\mathrm{X}$ and XI, which are the band records at Walnut Creek for 1909. (See also figs. 7 and 8, which show this data in diagrammatic form.) 
TABLE X.-Band records from 21 Bartlett pear trees, Walnut Creek, Cal., 1909.

\begin{tabular}{|c|c|c|c|c|c|c|c|}
\hline $\begin{array}{l}\text { Date of } \\
\text { collection. }\end{array}$ & $\begin{array}{l}\text { Number } \\
\text { of larvæ } \\
\text { and pupæ } \\
\text { collected. }\end{array}$ & $\begin{array}{l}\text { Date of } \\
\text { collection. }\end{array}$ & $\begin{array}{l}\text { Number } \\
\text { of larvæ } \\
\text { and pupæ } \\
\text { collected. }\end{array}$ & $\begin{array}{l}\text { Date of } \\
\text { collection. }\end{array}$ & $\begin{array}{c}\text { Number } \\
\text { of larvæ } \\
\text { and pupæe } \\
\text { collected. }\end{array}$ & $\begin{array}{c}\text { Date of } \\
\text { collection. }\end{array}$ & $\begin{array}{l}\text { Number } \\
\text { of larvæ } \\
\text { and pupæ } \\
\text { collected. }\end{array}$ \\
\hline 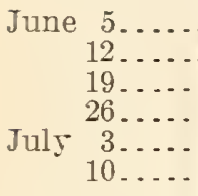 & $\begin{array}{l}24 \\
71 \\
45 \\
85 \\
49 \\
36\end{array}$ & 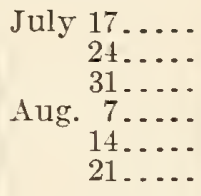 & $\begin{array}{l}22 \\
31 \\
15 \\
50 \\
55 \\
42\end{array}$ & $\begin{array}{r}\text { Aug. } 29 \ldots . \\
\text { Sept. } 5 \ldots . \\
12 \ldots \\
19 \ldots \\
\\
26 \ldots \\
\text { Oct. } 2 \ldots \\
2 \ldots\end{array}$ & $\begin{array}{r}13 \\
26 \\
11 \\
11 \\
3 \\
3\end{array}$ & $\begin{aligned} \text { Oct. } & 9 . . . . \\
& \text { Total. }\end{aligned}$ & $\frac{0}{592}$ \\
\hline
\end{tabular}

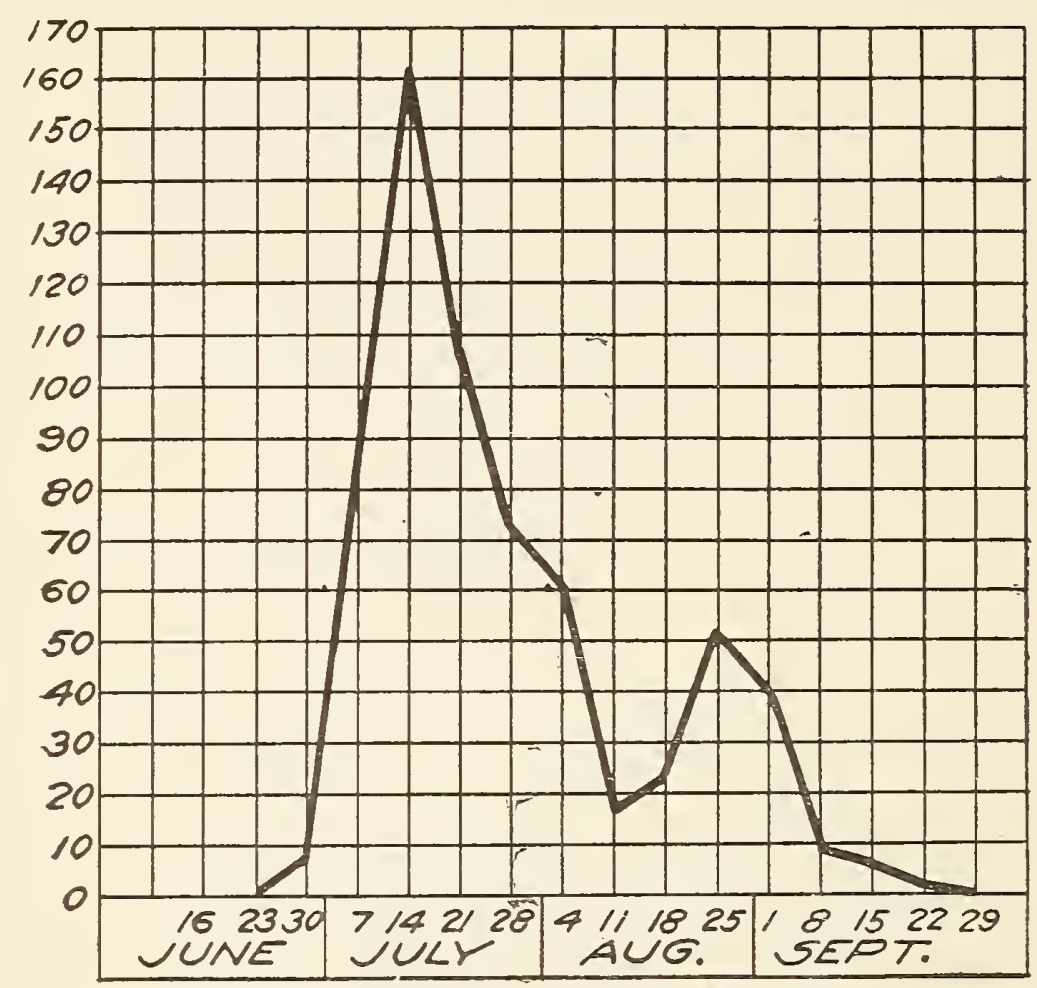

FIG. 9. -Weekly emergence of codling moths from material collected from banded apple and pear trees at Walnut Creek, Cal., 1909. (Original.)

TABLE XI._Band records from 10 apple trees, Walnut Creek, Cal., 1909.

\begin{tabular}{|c|c|c|c|c|c|c|c|}
\hline $\begin{array}{l}\text { Date of } \\
\text { collection. }\end{array}$ & $\begin{array}{l}\text { Number } \\
\text { of larvæ } \\
\text { and pupæ. } \\
\text { collected. }\end{array}$ & $\begin{array}{l}\text { Date of } \\
\text { collection. }\end{array}$ & $\begin{array}{l}\text { Number } \\
\text { of larvæ } \\
\text { and pupæ } \\
\text { collected. }\end{array}$ & $\begin{array}{l}\text { Date of } \\
\text { collection. }\end{array}$ & $\begin{array}{l}\text { Number } \\
\text { of larvæ } \\
\text { and pupæ } \\
\text { collected. }\end{array}$ & $\begin{array}{l}\text { Date of } \\
\text { collection. }\end{array}$ & $\begin{array}{l}\text { Number } \\
\text { of larvæ } \\
\text { and pupæ } \\
\text { collected. }\end{array}$ \\
\hline $\begin{array}{r}\text { June } 5 . . \\
12 . \\
19 . \\
26 \ldots \\
\text { July } 3 . . \\
10 .\end{array}$ & $\begin{array}{r}32 \\
98 \\
164 \\
223 \\
79 \\
-\quad 63\end{array}$ & $\begin{array}{rr}\text { July } 17 . . \\
24 \ldots \\
31 \ldots \\
\text { Aug. } 7 \ldots \\
14 \ldots \\
21 \ldots\end{array}$ & $\begin{array}{r}99 \\
25 \\
56 \\
95 \\
128 \\
125\end{array}$ & $\begin{array}{r}\text { Aug. } 28 . . \\
\text { Sept. } 5 \ldots \\
12 \ldots \\
19 \ldots \\
26 \ldots \\
\text { Oct.. } 3 . .\end{array}$ & \begin{tabular}{r|}
60 \\
65 \\
43 \\
2 \\
3 \\
6
\end{tabular} & $\begin{array}{r}\text { Oct. } 10 \ldots . \\
\text { Total. }\end{array}$ & $\frac{5}{1,371}$ \\
\hline
\end{tabular}

All larvæ and pupæ collected in making the two band records in 1909 were put together each week and kept in jars for the emergence of adults. The maximum emergence came July 8 to 14 . The records are given in Table XII. (See also fig. 9.) 
TABLE XII.-Emergence of moths from material collected under bands on pear and apple trees, Walnut Creek, Cal., 1909.

\begin{tabular}{|c|c|c|c|c|c|c|c|}
\hline $\begin{array}{c}\text { Date of } \\
\text { emergence. }\end{array}$ & $\begin{array}{l}\text { Number } \\
\text { of moths. }\end{array}$ & $\begin{array}{c}\text { Date of } \\
\text { emergence. }\end{array}$ & $\begin{array}{l}\text { Number } \\
\text { of moths. }\end{array}$ & $\begin{array}{c}\text { Date of } \\
\text { emergence. }\end{array}$ & $\begin{array}{l}\text { Number } \\
\text { of moths. }\end{array}$ & $\begin{array}{c}\text { Date of } \\
\text { emergence. }\end{array}$ & $\begin{array}{l}\text { Number } \\
\text { of moths. }\end{array}$ \\
\hline $\begin{array}{r}\text { June } 23 . \\
30 . \\
\text { July } 7 . .\end{array}$ & $\begin{array}{r}3 \\
7 \\
91\end{array}$ & $\begin{array}{r}\text { July } 21 . \\
28 . \\
\text { Aug. } 4 .\end{array}$ & $\begin{array}{r}114 \\
73 \\
63\end{array}$ & $\begin{array}{r}\text { Aug. } 18 . \\
25 . \\
\text { Sept. } 1 .\end{array}$ & $\begin{array}{l}24 \\
52 \\
40\end{array}$ & Sept.15 & $\begin{array}{l}6 \\
1\end{array}$ \\
\hline 14 & 161 & & 18 & & 10 & Total & 663 \\
\hline
\end{tabular}

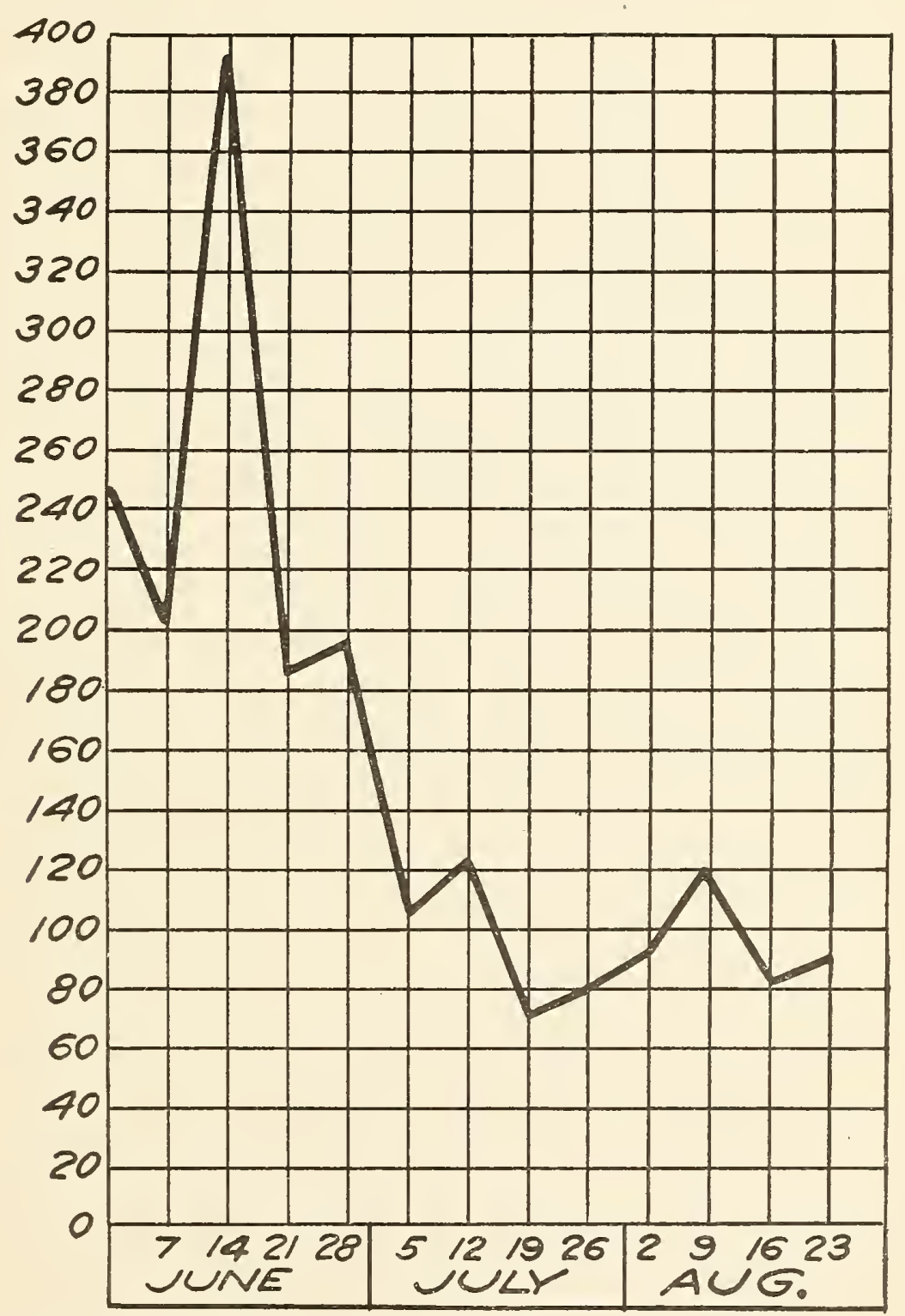

FIG. 10.-Band records from 11 apple trees at Walnut Creek, Cal., 1910. (Original.)

TABLE XIII.-Band records from 15 Bartlett pear trees, Suisun, Cal., 1910.

\begin{tabular}{|c|c|c|c|c|c|c|c|}
\hline $\begin{array}{l}\text { Date of } \\
\text { collection. }\end{array}$ & $\begin{array}{l}\text { Number } \\
\text { of larvæ } \\
\text { and pupæ } \\
\text { collected. }\end{array}$ & $\begin{array}{l}\text { Date of } \\
\text { collection. }\end{array}$ & $\begin{array}{l}\text { Number } \\
\text { of larvæ } \\
\text { and pupæ } \\
\text { collected. }\end{array}$ & $\begin{array}{l}\text { Date of } \\
\text { collection. }\end{array}$ & $\begin{array}{l}\text { Number } \\
\text { of larvæ } \\
\text { and pupæ } \\
\text { collected. }\end{array}$ & $\begin{array}{c}\text { Date of } \\
\text { collection. }\end{array}$ & $\begin{array}{l}\text { Number } \\
\text { of larvæ } \\
\text { and pupæ } \\
\text { collected. }\end{array}$ \\
\hline 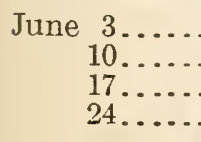 & $\begin{array}{l}55 \\
58 \\
68 \\
84\end{array}$ & $\begin{array}{r}\text { July } 1 . . \\
8 . . \\
15 .\end{array}$ & $\begin{array}{l}84 \\
37 \\
48\end{array}$ & $\begin{array}{r}\text { July } 22 . . \\
29 . \\
\text { Aug. } 5 .\end{array}$ & $\begin{array}{l}28 \\
50 \\
68\end{array}$ & $\begin{array}{r}\text { Aug. } 12 \ldots \\
\text { Total }\end{array}$ & $\frac{38}{618}$ \\
\hline
\end{tabular}

Table XIV, showing the band record from 11 apple trees at Walnut Creek in 1910, is illustrated diagrammatically in figure 10; and Table XIII, showing band records taken from 15 Bartlett pear trees at Suisun, Cal., in 1910, is illustrated in figure 11. 
TABLE XIV.-Band records from 11 apple trees, Walnut Creek, Cal., 1910.

\begin{tabular}{|c|c|c|c|c|c|c|c|}
\hline $\begin{array}{l}\text { Date of } \\
\text { collection. }\end{array}$ & $\begin{array}{l}\text { Number } \\
\text { of larvæ } \\
\text { and pupæ } \\
\text { collected. }\end{array}$ & $\begin{array}{l}\text { Date of } \\
\text { collection. }\end{array}$ & $\begin{array}{l}\text { Number } \\
\text { of larvæ } \\
\text { and pupæ } \\
\text { collected. }\end{array}$ & $\begin{array}{l}\text { Date of } \\
\text { collection. }\end{array}$ & $\begin{array}{l}\text { Number } \\
\text { of larvæ } \\
\text { and pupæ } \\
\text { collected. }\end{array}$ & $\begin{array}{l}\text { Date of } \\
\text { collection. }\end{array}$ & $\begin{array}{l}\text { Number } \\
\text { of larvæ } \\
\text { and pupæ } \\
\text { collected. }\end{array}$ \\
\hline June $\begin{array}{r}1 \ldots \\
7 \ldots \\
14 \ldots \\
21 \ldots\end{array}$ & $\begin{array}{l}252 \\
200 \\
391 \\
185\end{array}$ & $\begin{array}{rr}\text { June } 28 . . . \\
\text { July } 5 . . \\
12 \ldots \\
19 . .\end{array}$ & $\begin{array}{r}196 \\
105 \\
125 \\
71\end{array}$ & 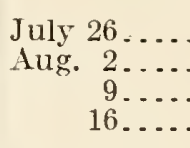 & $\begin{array}{r}80 \\
93 \\
120 \\
82\end{array}$ & $\begin{array}{r}\text { Aug. } 23 . . . \\
\quad \text { Total }\end{array}$ & $\frac{88}{1,991}$ \\
\hline
\end{tabular}

It will be seen (fig. 10) that the maximum number of larvæ and pupæ

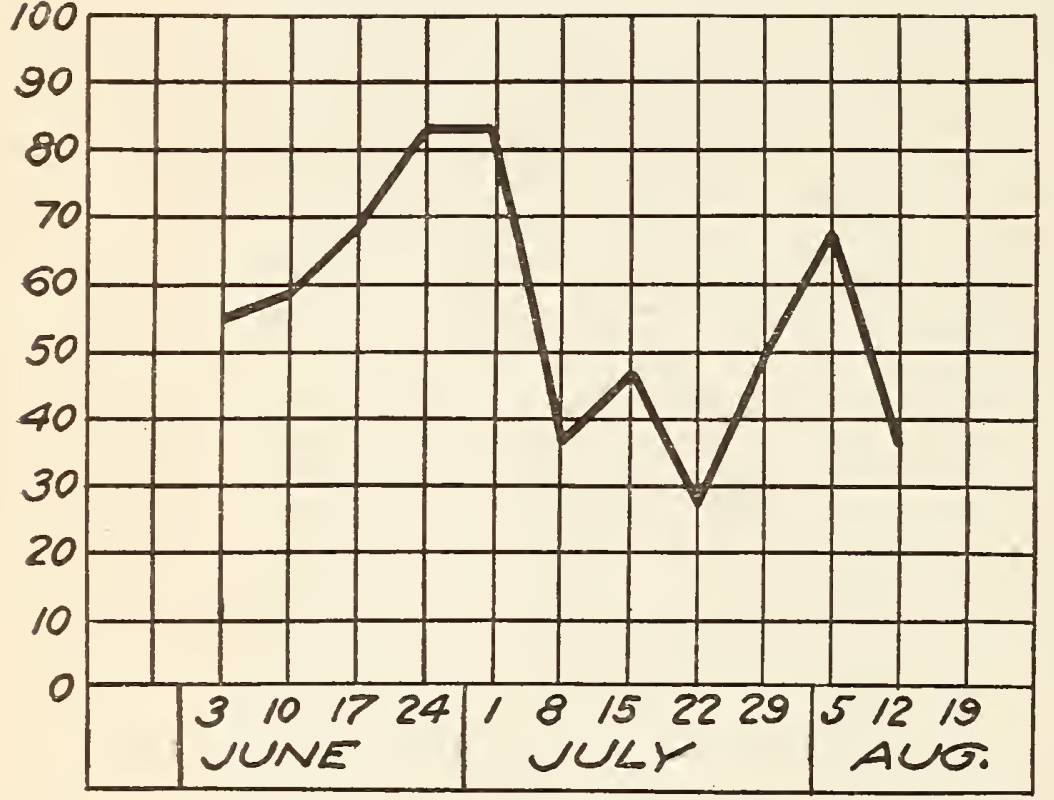

FIG. 11.-Band records from 15 Bartlett pear trees at Suisun, Cal., 1910. (Original.)

was collected on June 14, 1910, as against June 26, 1909 (figs. 7 and 8), showing that the greatest number of larvæ and pupæ was present nearly two weeks earlier in 1910 than in 1909.

Tables XV and XVIshow emergence of moths from material collected under bands at Walnut Creek and Suisun in the summer of 1910 .

Both tables are illustrated diagrammatically in figures 12 and 13.

TABLE XT. - Weekly record of emergence of moths from material collected under bands on 11 apple trees, Walnut Creek, Cal., 1910.

\begin{tabular}{|c|c|c|c|c|c|c|c|}
\hline $\begin{array}{l}\text { Date of } \\
\text { emergence. }\end{array}$ & $\begin{array}{l}\text { Number } \\
\text { of moths } \\
\text { emerged. }\end{array}$ & $\begin{array}{l}\text { Date of } \\
\text { emergence. }\end{array}$ & $\begin{array}{l}\text { Number } \\
\text { of moths } \\
\text { emerged. }\end{array}$ & $\begin{array}{l}\text { Date of } \\
\text { emergence. }\end{array}$ & $\begin{array}{l}\text { Number } \\
\text { of moths } \\
\text { emerged. }\end{array}$ & $\begin{array}{l}\text { Date of } \\
\text { emergence. }\end{array}$ & $\begin{array}{l}\text { Number } \\
\text { of moths } \\
\text { emerged. }\end{array}$ \\
\hline 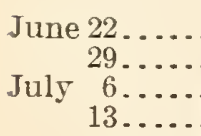 & $\begin{array}{r}3 \\
175 \\
133 \\
228\end{array}$ & $\begin{array}{r}\text { July } \begin{array}{r}20 \ldots . \\
27 \ldots\end{array} \\
\text { Aug, } 3 \ldots \ldots \\
\end{array}$ & $\begin{array}{l}65 \\
84 \\
30\end{array}$ & $\begin{array}{r}\text { Aug. } 10 \ldots . \\
17 \ldots . \\
24 \ldots\end{array}$ & $\begin{array}{l}36 \\
36 \\
76\end{array}$ & $\begin{array}{r}\text { Aug. } 31 . \\
\text { Sept. } 7 . \\
14 .\end{array}$ & $\begin{array}{r}50 \\
15 \\
4\end{array}$ \\
\hline
\end{tabular}

TABLE XTI.-Weekly record of emergence of moths from material collected under bands on 15 Bartlett pear trees, Suisun, Cal., 1910.

\begin{tabular}{|c|c|c|c|c|c|c|c|}
\hline $\begin{array}{c}\text { Date of } \\
\text { emergence. }\end{array}$ & $\begin{array}{l}\text { Number } \\
\text { of moths } \\
\text { emerged. }\end{array}$ & $\begin{array}{c}\text { Date of } \\
\text { emergence. }\end{array}$ & $\begin{array}{l}\text { Number } \\
\text { of moths } \\
\text { emerged. }\end{array}$ & $\begin{array}{l}\text { Date of } \\
\text { emergence. }\end{array}$ & $\begin{array}{l}\text { Number } \\
\text { of moths } \\
\text { emerged. }\end{array}$ & $\begin{array}{l}\text { Date of } \\
\text { emergence. }\end{array}$ & $\begin{array}{l}\text { Number } \\
\text { of moths } \\
\text { emerged. }\end{array}$ \\
\hline 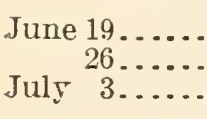 & $\begin{array}{r}1 \\
13 \\
25\end{array}$ & $\begin{array}{r}\text { July } 10 . . \\
17 . . \\
24 .\end{array}$ & $\begin{array}{l}74 \\
26 \\
18\end{array}$ & $\begin{array}{r}\text { July } 31 . . \\
\text { Aug. } \begin{array}{r}7 \\
14 . .\end{array}\end{array}$ & $\begin{array}{l}7 \\
9 \\
6\end{array}$ & $\begin{array}{r}\text { Aug. } 21 \ldots . \\
28 \ldots \\
\text { Sept. } 4 \ldots \ldots\end{array}$ & $\begin{array}{r}14 \\
2 \\
2\end{array}$ \\
\hline
\end{tabular}

There is a noticeable difference in the dates of development of the first-brood larvæ and the emergence of moths from this brood in the 
interior counties and in the coast counties. The tables giving the band records and emergence of moths for Walnut Creek and Suisun sections show the maximum emergence of moths to be about three weeks earlier than the maximum emergence at San Jose. Fxtended field observations covering the seasons of 1909-10 confirm these laboratory records. Many first-brood larvæ were hatching and entering fruit in early July in Santa Clara, Santa Cruz, and Monterey and in Mendocino and Humboldt Counties along the coast, while all this brood was in the fruit by the 1st of June in the adjoining interior counties.

Table XVII, giving the band record, and Table XVIII, giving the record of the emergence of moths, show the conditions for Santa Clara County. The band record was made in an unsprayed apple orchard. The data

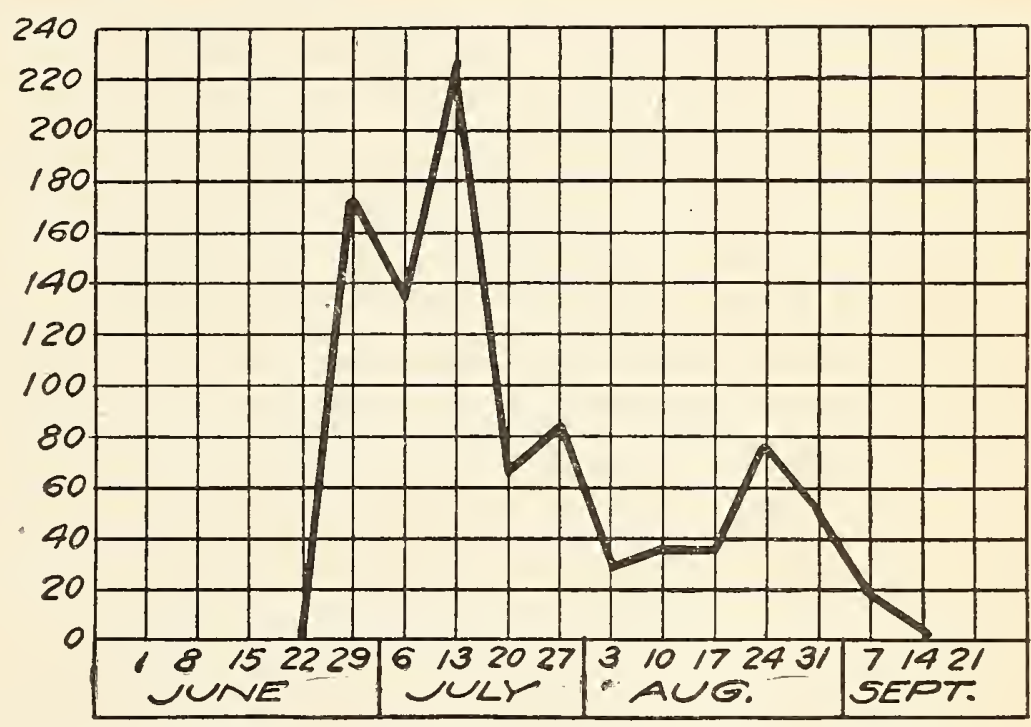

FIG. 12.-Weekly emergence of moths from material collected under bands on 11 apple trees at Walnut Creek, Cal., 1910. (Original.) given in the respective tables are shown diagrammatically in figures 14 and 15.

TaBle XVII.-Band records from apple trees, San Jose, Cal., 1909.

\begin{tabular}{|c|c|c|c|c|c|c|c|}
\hline $\begin{array}{c}\text { Date of } \\
\text { collection. }\end{array}$ & $\begin{array}{l}\text { Number } \\
\text { of larvæ } \\
\text { and pu- } \\
\text { pæ col- } \\
\text { lected. }\end{array}$ & $\begin{array}{l}\text { Date of } \\
\text { collection. }\end{array}$ & $\begin{array}{l}\text { Number } \\
\text { of larvæ } \\
\text { and pu- } \\
\text { pæ col- } \\
\text { lected. }\end{array}$ & $\begin{array}{l}\text { Date of } \\
\text { collection. }\end{array}$ & $\begin{array}{l}\text { Number } \\
\text { of larvæ } \\
\text { and pu- } \\
\text { pæ col- } \\
\text { lected. }\end{array}$ & $\begin{array}{c}\text { Date of } \\
\text { collection. }\end{array}$ & $\begin{array}{l}\text { Number } \\
\text { of larvæ } \\
\text { and pu- } \\
\text { pæ col- } \\
\text { lected. }\end{array}$ \\
\hline $\begin{array}{rr}\text { June } & 21 . . \\
& 28 . . \\
\text { July } & 5 . . \\
12 . . \\
19 . . \\
26 . .\end{array}$ & $\begin{array}{r}1,602 \\
2,276 \\
946 \\
1,565 \\
1,804 \\
1,041\end{array}$ & $\begin{array}{rr}\text { Aug. } & 2 . . \\
9 \ldots \\
16 .- \\
23 \ldots \\
30 . \\
\text { Sept. } 6 . .\end{array}$ & $\begin{array}{l}647 \\
365 \\
227 \\
645 \\
880 \\
951\end{array}$ & $\begin{array}{rr}\text { Sept. } 13 \ldots \\
& 20 \ldots \\
& 27 \ldots \\
& 4 \ldots \\
& 11 \ldots \\
& 18 \ldots\end{array}$ & $\begin{array}{r}634 \\
649 \\
271 \\
135 \\
92 \\
18\end{array}$ & 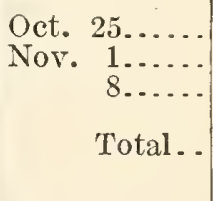 & $\begin{array}{r}1 \\
8 \\
3 \\
14,759\end{array}$ \\
\hline
\end{tabular}

TABLE XVIII.-Emergence of moths from banded apple trees, San Jose, Cal., 1909.

\begin{tabular}{|c|c|c|c|c|c|c|c|}
\hline $\begin{array}{c}\text { Date of } \\
\text { emergence. }\end{array}$ & $\begin{array}{l}\text { Number } \\
\text { of moths. }\end{array}$ & $\begin{array}{l}\text { Date of } \\
\text { emergence. }\end{array}$ & $\begin{array}{l}\text { Number } \\
\text { of moths. }\end{array}$ & $\begin{array}{l}\text { Date of } \\
\text { emergence. }\end{array}$ & $\begin{array}{l}\text { Number } \\
\text { of moths. }\end{array}$ & $\begin{array}{c}\text { Date of } \\
\text { emergence. }\end{array}$ & $\begin{array}{l}\text { Number } \\
\text { of moths. }\end{array}$ \\
\hline 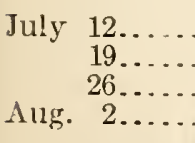 & $\begin{array}{r}55 \\
346 \\
731 \\
777\end{array}$ & 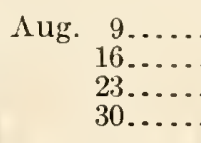 & $\begin{array}{l}884 \\
694 \\
441 \\
165\end{array}$ & 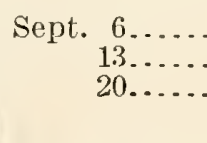 & $\begin{array}{r}40 \\
46 \\
133\end{array}$ & $\begin{array}{r}\text { Sept. } 27 . . . \\
\text { Total. }\end{array}$ & $\frac{8}{4,320}$ \\
\hline
\end{tabular}


YATURAL ENEMIES.

PARASITES.

At frequent intervals throughout the summer quantities of wormy

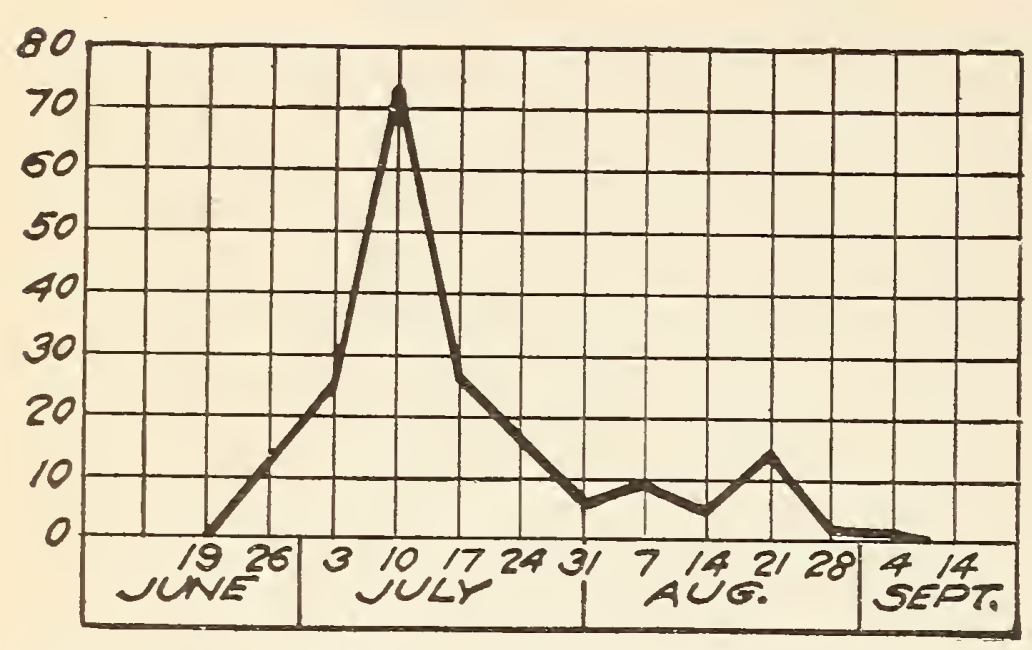

FIG. 13.- WeekIy emergence of moths from material collected under bands on 15 pear trees, at Suisun Cal., 1910. (Original.) fruit were brought into the laboratory from different orchards throughout Contra Costa County and kept in jars in shaded places out of doors, but not a single hymenopterous or dipterous parasite was reared from all the worms in this fruit. Neither was there any reared from the material taken under bands on pear and apple trees.

PREDACEOUS ENEMIES.

Occasionally a carabid larra was found under the bands eating the larvæ, and late in the season a number of tenebrionid beetles, some of which were compared to beetles determined by Mr. E. A. Schwarz, of the Bureau of Entomology, as Eulabis rufipes Esch. and found to

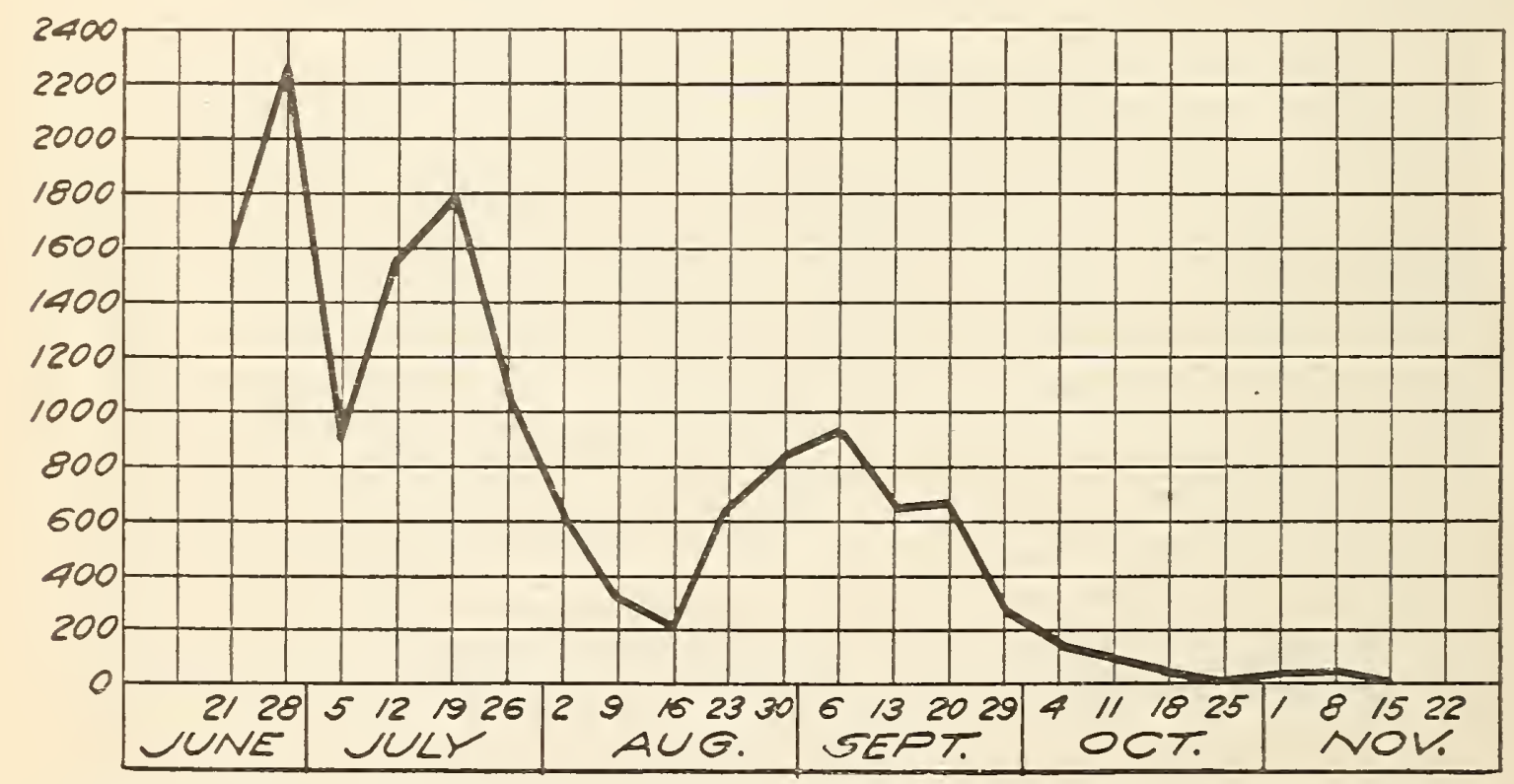

FIG. 14.-Band records of the codling moth from apple trees at San Jose, Cal., 1909. (Original.)

be the same, were found under bands with partly eaten larræ, but in no case were these beetles found actually eating the larræ.

THE CONTROL OF THE CODIING MOTH ON PEARS IN CALIFORNIA.

There are some necessary differences in the treatment of pear and apple orchards for the control of the codling moth. The calrx lobes 
in normal pears do not close up so quickly as in the case of the apple. The blooming period of pears in California is usually very much longer, sometimes lasting from three to five weeks from the first to last appearing blossoms. There is also a "second crop" of fruit which is somewhat later than the other and longer stemmed. It is noticeable that the calyx lobes on this second-crop fruit close up tightly very quickly after the shedding of the petals. As a large percentage of the first-brood worms enters the fruit through the calyx, it is necessary to have poison in the calyx cups before they are closed. The first larvæ begin to hatch some three to five weeks after the blooming period is over. At least one and preferably two thorough sprayings should be given before this period of hatching of the larvæ.

Opportunity was offered during the season of 1909 to test the value of two and three treatments on pears and in 1910 a larger set of experiments, to determine the number of applications most efficient and the value of each as compared with no treatment at all, was carried out. The results of

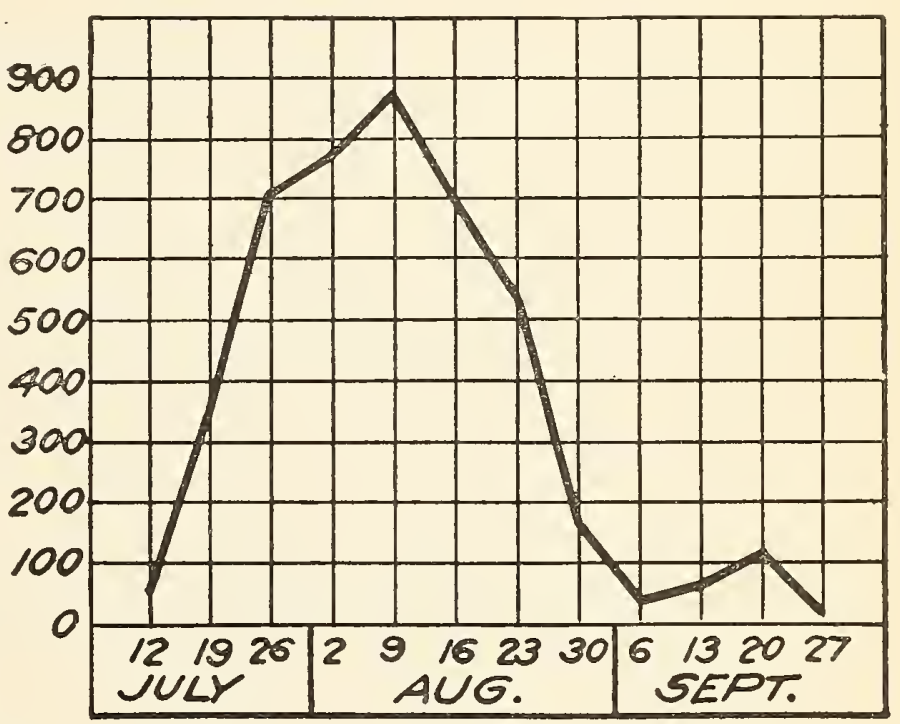

FIG. 15.-Weekly emergence of codling moths from larvæ collected from banded apple trees at San Jose, Cal., 1909. (Original.) these and certain other observations are given in the following pages.

EFFECT OF SPRAYS ON PLACES OF ENTRANCE INTO PEARS BY LARVA.

Records were kept throughout both seasons for the entrance holes of all the larvæ in the fruit of 10 trees in each block used in the spraying experiments.

It is interesting to note the places of entrance in the fruit by the larvæ, the effect of the different applications on the comparative percentages of worms entering at the calyx and at the side and stem, and where the greater number of larvæ was killed. These data are given in Tables XIX to XXXIII, inclusive. (Tables XIX to XXI are the records from the 1909 experiments at Concord, Cal.; Tables XXII to XXIX, the records from the 1910 experiments at Walnut Creek, Cal.; and Tables XXX to XXXIII the records from the experiments at Suisun, Cal., in 1910.) Only the worms entering at the calyx cavity proper are recorded as calyx worms; all larvæ entering the fruit through side, base, and around the stem are recorded under the heading of side and stem. 
TABLE XIX.-Comparison of number of worms entering pears at calyx, and at side and stem. Plat I, sprayed three times, Concord, Cal., 1909.

\begin{tabular}{|c|c|c|c|c|c|c|c|c|c|c|c|}
\hline \multirow[b]{2}{*}{ Tree No. } & \multicolumn{3}{|c|}{$\begin{array}{l}\text { Worms in windfallen } \\
\text { fruit. }\end{array}$} & \multicolumn{3}{|c|}{$\begin{array}{l}\text { Worms in fruit from } \\
\text { trees. }\end{array}$} & \multicolumn{3}{|c|}{ Total number of- } & \multicolumn{2}{|c|}{ Percentage of- } \\
\hline & $\begin{array}{l}\text { Num- } \\
\text { ber of } \\
\text { worms. }\end{array}$ & $\begin{array}{c}\text { En- } \\
\text { tered } \\
\text { at } \\
\text { calyx. }\end{array}$ & $\begin{array}{c}\text { En- } \\
\text { tered } \\
\text { at side } \\
\text { and } \\
\text { stem. }\end{array}$ & $\begin{array}{l}\text { Num- } \\
\text { ber of } \\
\text { worms. }\end{array}$ & $\begin{array}{c}\text { En- } \\
\text { tered } \\
\text { at } \\
\text { calyx. }\end{array}$ & $\begin{array}{l}\text { En- } \\
\text { tered } \\
\text { at side } \\
\text { and } \\
\text { stem. }\end{array}$ & Worms. & $\begin{array}{c}\text { Worms } \\
\text { entered } \\
\text { at } \\
\text { calyx. }\end{array}$ & $\begin{array}{l}\text { Worms } \\
\text { entered } \\
\text { at side } \\
\text { and } \\
\text { stem. }\end{array}$ & $\begin{array}{c}\text { Worms } \\
\text { entered } \\
\text { at } \\
\text { calyx. }\end{array}$ & $\begin{array}{l}\text { Worms } \\
\text { entered } \\
\text { at side } \\
\text { and } \\
\text { stem. }\end{array}$ \\
\hline $\begin{array}{r}1 \ldots \ldots \\
2 \ldots \ldots \\
3 \ldots \ldots \\
4 \ldots \\
5 \ldots \ldots \\
6 \ldots \ldots \\
7 \ldots \ldots \\
8 \ldots \ldots \\
9 \ldots \ldots \\
10 \ldots \ldots \\
\ldots \ldots \\
\ldots\end{array}$ & $\begin{array}{r}23 \\
5 \\
8 \\
14 \\
4 \\
19 \\
11 \\
8 \\
19 \\
15\end{array}$ & $\begin{array}{l}2 \\
6 \\
5\end{array}$ & $\begin{array}{r}15 \\
3 \\
3 \\
8 \\
3 \\
12 \\
8 \\
6 \\
13 \\
10\end{array}$ & $\begin{array}{l}39 \\
.34 \\
24 \\
43 \\
20 \\
21 \\
22 \\
17 \\
19 \\
14\end{array}$ & $\begin{array}{r}15 \\
8 \\
7 \\
6 \\
6 \\
9 \\
8 \\
11 \\
6 \\
3\end{array}$ & $\begin{array}{r}24 \\
26 \\
17 \\
37 \\
14 \\
12 \\
14 \\
6 \\
13 \\
11\end{array}$ & $\begin{array}{l}62 \\
39 \\
32 \\
57 \\
24 \\
40 \\
33 \\
25 \\
38 \\
29\end{array}$ & $\begin{array}{r}23 \\
10 \\
12 \\
12 \\
7 \\
16 \\
11 \\
13 \\
12 \\
8\end{array}$ & $\begin{array}{l}39 \\
29 \\
20 \\
45 \\
17 \\
24 \\
22 \\
12 \\
26 \\
21\end{array}$ & $\begin{array}{l}37.10 \\
25.64 \\
37.50 \\
21.05 \\
29.16 \\
40.00 \\
33.33 \\
52.00 \\
31.57 \\
27.58\end{array}$ & $\begin{array}{l}62.90 \\
74.36 \\
62.50 \\
78.95 \\
70.84 \\
60.00 \\
66.67 \\
48.00 \\
68.43 \\
72.42\end{array}$ \\
\hline $\begin{array}{l}\text { Total, trees } \\
1-10 . . .\end{array}$ & 126 & 45 & 81 & 253 & 79 & 174 & 379 & 124 & 255 & 32.72 & 67.28 \\
\hline
\end{tabular}

TABLE XX.-Comparison of number of worms entering pears at calyx, and at side and stem. Plat II, unsprayed, Concord, Cal., 1909.

\begin{tabular}{|c|c|c|c|c|c|c|c|c|c|c|c|}
\hline \multirow[b]{2}{*}{ Tree No. } & \multicolumn{3}{|c|}{$\begin{array}{l}\text { Worms in windfallen } \\
\text { fruit. }\end{array}$} & \multicolumn{3}{|c|}{$\begin{array}{l}\text { Worms in fruit from } \\
\text { trees. }\end{array}$} & \multicolumn{3}{|c|}{ Total number of- } & \multicolumn{2}{|c|}{ Percentage of- } \\
\hline & $\begin{array}{l}\text { Num- } \\
\text { ber of } \\
\text { worms. }\end{array}$ & $\begin{array}{c}\text { En- } \\
\text { tered } \\
\text { at } \\
\text { calyx. }\end{array}$ & $\begin{array}{l}\text { En- } \\
\text { tered } \\
\text { at side } \\
\text { and } \\
\text { stem. }\end{array}$ & $\begin{array}{c}\text { Num- } \\
\text { ber of } \\
\text { worms. }\end{array}$ & $\begin{array}{c}\text { En- } \\
\text { tered } \\
\text { at } \\
\text { calyx. }\end{array}$ & $\begin{array}{l}\text { En- } \\
\text { tered } \\
\text { at side } \\
\text { and } \\
\text { stem. }\end{array}$ & Worms. & $\begin{array}{l}\text { Worms } \\
\text { entered } \\
\text { at } \\
\text { calyx. }\end{array}$ & $\begin{array}{l}\text { Worms } \\
\text { entered } \\
\text { at side } \\
\text { and } \\
\text { stem. }\end{array}$ & $\begin{array}{c}\text { Worms } \\
\text { entered } \\
\text { at } \\
\text { calyx. }\end{array}$ & $\begin{array}{l}\text { Worms } \\
\text { entered } \\
\text { at side } \\
\text { and } \\
\text { stem. }\end{array}$ \\
\hline $\begin{array}{c}1 . \\
2 . \\
3 . \\
4 . \\
5 . \\
6 . \\
7 . \\
8 . \\
9 . \\
10 .\end{array}$ & $\begin{array}{l}311 \\
327 \\
248 \\
213 \\
262 \\
230 \\
201 \\
242 \\
242 \\
295\end{array}$ & $\begin{array}{l}244 \\
200 \\
172 \\
200 \\
180 \\
172 \\
194 \\
163 \\
236\end{array}$ & $\begin{array}{l}48 \\
41 \\
62 \\
50 \\
29 \\
48 \\
79 \\
59\end{array}$ & $\begin{array}{l}833 \\
551 \\
425 \\
350 \\
459 \\
560 \\
596 \\
395 \\
460 \\
408\end{array}$ & $\begin{array}{l}635 \\
418 \\
318 \\
238 \\
335 \\
402 \\
444 \\
258 \\
292 \\
287\end{array}$ & $\begin{array}{l}198 \\
133 \\
107 \\
112 \\
124 \\
158 \\
152 \\
137 \\
168 \\
121\end{array}$ & $\begin{array}{r}1,144 \\
878 \\
673 \\
563 \\
721 \\
790 \\
797 \\
637 \\
702 \\
703\end{array}$ & $\begin{array}{l}866 \\
662 \\
518 \\
410 \\
535 \\
582 \\
616 \\
452 \\
455 \\
523\end{array}$ & $\begin{array}{l}278 \\
216 \\
155 \\
153 \\
186 \\
208 \\
181 \\
185 \\
247 \\
180\end{array}$ & & $\begin{array}{l}24.31 \\
24.61 \\
23.00 \\
27.14 \\
25.88 \\
26.30 \\
22.73 \\
29.01 \\
35.15 \\
25.69\end{array}$ \\
\hline $\begin{array}{l}\text { Total, } t \\
1-10\end{array}$ & 2,571 & 1,992 & 579 & 5,037 & 3,627 & 1,410 & 7,608 & 5,619 & 1,989 & 73.86 & 26.14 \\
\hline
\end{tabular}

TABLE XXI.-Comparison of number of worms entering pears at calyx and at side and stem. Plat III, sprayed twice, Concord, Cal., 1909.

\begin{tabular}{|c|c|c|c|c|c|c|c|c|c|c|c|}
\hline \multirow[b]{2}{*}{ Tree No. } & \multicolumn{3}{|c|}{$\begin{array}{l}\text { Worms in windfallen } \\
\text { fruit. }\end{array}$} & \multicolumn{3}{|c|}{$\begin{array}{l}\text { Worms in fruit from } \\
\text { trees. }\end{array}$} & \multicolumn{3}{|c|}{ Total number of- } & \multicolumn{2}{|c|}{ Percentage of- } \\
\hline & $\begin{array}{l}\text { Num- } \\
\text { ber of } \\
\text { worms. }\end{array}$ & $\begin{array}{c}\text { En- } \\
\text { tered } \\
\text { at } \\
\text { calyx. }\end{array}$ & $\begin{array}{l}\text { En- } \\
\text { tered } \\
\text { at side } \\
\text { and } \\
\text { stem. }\end{array}$ & $\begin{array}{l}\text { Num- } \\
\text { ber of } \\
\text { worms. }\end{array}$ & $\begin{array}{l}\text { En- } \\
\text { tered } \\
\text { at } \\
\text { calyx. }\end{array}$ & $\begin{array}{l}\text { En- } \\
\text { tered } \\
\text { at side } \\
\text { and } \\
\text { stem. }\end{array}$ & Worms. & $\begin{array}{c}\text { Worms } \\
\text { entered } \\
\text { at } \\
\text { calyx. }\end{array}$ & $\begin{array}{l}\text { Worms } \\
\text { entered } \\
\text { at side } \\
\text { and } \\
\text { stem. }\end{array}$ & $\begin{array}{c}\text { Worms } \\
\text { entered } \\
\text { at } \\
\text { calyx. }\end{array}$ & $\begin{array}{l}\text { Worms } \\
\text { entered } \\
\text { at side } \\
\text { and } \\
\text { stem. }\end{array}$ \\
\hline $\begin{array}{c}1 \ldots \ldots \\
2 \ldots \\
3 \ldots \\
4 \ldots \\
5 \ldots \\
6 \ldots \\
7 \ldots \\
8 \ldots \\
9 \ldots \\
10 \ldots \\
\ldots\end{array}$ & $\begin{array}{l}43 \\
62 \\
21 \\
50 \\
62 \\
54 \\
22 \\
35 \\
37 \\
31\end{array}$ & $\begin{array}{l}19 \\
36 \\
11 \\
29 \\
36 \\
27 \\
11 \\
23 \\
21 \\
19\end{array}$ & $\begin{array}{l}24 \\
26 \\
10 \\
21 \\
26 \\
27 \\
11 \\
12 \\
16 \\
12\end{array}$ & $\begin{array}{r}140 \\
175 \\
95 \\
145 \\
209 \\
130 \\
95 \\
111 \\
105 \\
109\end{array}$ & $\begin{array}{r}92 \\
103 \\
49 \\
96 \\
152 \\
93 \\
77 \\
71 \\
72 \\
72\end{array}$ & $\begin{array}{l}48 \\
72 \\
46 \\
49 \\
57 \\
37 \\
18 \\
40 \\
33 \\
37\end{array}$ & $\begin{array}{l}237 \\
116 \\
195 \\
271 \\
184 \\
117 \\
146 \\
142 \\
140\end{array}$ & $\begin{array}{r}139 \\
60 \\
125 \\
188 \\
120 \\
88 \\
94 \\
93 \\
91\end{array}$ & $\begin{array}{l}72 \\
98 \\
56 \\
70 \\
83 \\
64 \\
29 \\
52 \\
49 \\
49\end{array}$ & & $\begin{array}{l}39.34 \\
41.35 \\
48.28 \\
35.90 \\
30.63 \\
34.79 \\
24.79 \\
35.62 \\
34.58 \\
35.00\end{array}$ \\
\hline $\begin{array}{c}\text { Tota } 1, \\
\text { trees } 1- \\
10 \ldots .\end{array}$ & 417 & 232 & 185 & 1,314 & 877 & 437 & 1,731 & 1,109 & 622 & 63.97 & 36.03 \\
\hline
\end{tabular}


TABLE XXII.-Comparison of number of worms entering pears at calyx and at side and stem. Plat I, sprayed three times, Walnut Creek, Cal., 1910.

\begin{tabular}{|c|c|c|c|c|c|c|c|c|c|c|c|}
\hline \multirow[b]{2}{*}{ Tree No. } & \multicolumn{3}{|c|}{$\begin{array}{l}\text { Worms in windfallen } \\
\text { fruit. }\end{array}$} & \multicolumn{3}{|c|}{$\begin{array}{l}\text { Worms in fruit from } \\
\text { trees. }\end{array}$} & \multicolumn{3}{|c|}{ Total number of- } & \multicolumn{2}{|c|}{ Percentage of- } \\
\hline & $\begin{array}{l}\text { Num- } \\
\text { ber of } \\
\text { worms. }\end{array}$ & $\begin{array}{c}\text { En- } \\
\text { tered } \\
\text { at } \\
\text { calyx. }\end{array}$ & $\begin{array}{l}\text { En- } \\
\text { tered } \\
\text { at side } \\
\text { and } \\
\text { stem. }\end{array}$ & $\begin{array}{c}\text { Num- } \\
\text { ber of } \\
\text { worms. }\end{array}$ & $\begin{array}{c}\text { En- } \\
\text { tered } \\
\text { at } \\
\text { calyx. }\end{array}$ & $\begin{array}{l}\text { En- } \\
\text { tered } \\
\text { at side } \\
\text { and } \\
\text { stem. }\end{array}$ & Worms. & $\begin{array}{c}\text { Worms } \\
\text { entered } \\
\text { at } \\
\text { calyx. }\end{array}$ & $\begin{array}{l}\text { Worms } \\
\text { entered } \\
\text { at side } \\
\text { and } \\
\text { stem. }\end{array}$ & $\begin{array}{c}\text { Worms } \\
\text { entcred } \\
\text { at } \\
\text { calyx. }\end{array}$ & $\begin{array}{l}\text { Worms } \\
\text { entered } \\
\text { at side } \\
\text { and } \\
\text { stem. }\end{array}$ \\
\hline $\begin{array}{c}1 \ldots \ldots \\
2 \ldots \ldots \\
3 \ldots \ldots \\
4 \ldots \ldots \\
5 \ldots \ldots \\
6 \ldots \ldots \\
7 \ldots \ldots \\
8 \ldots \ldots \\
9 \ldots \ldots \\
10 \ldots \ldots \\
\ldots \ldots \\
\ldots\end{array}$ & $\begin{array}{l}1 \\
3 \\
1 \\
2 \\
3 \\
2 \\
8 \\
6 \\
2 \\
1\end{array}$ & $\begin{array}{l}0 \\
0 \\
0 \\
0 \\
0 \\
0 \\
1 \\
1 \\
0 \\
0\end{array}$ & $\begin{array}{l}1 \\
3 \\
1 . \\
2 \\
3 \\
2 \\
7 \\
5 \\
5 \\
2 \\
1\end{array}$ & \begin{tabular}{r|}
9 \\
7 \\
5 \\
4 \\
6 \\
7 \\
21 \\
19 \\
15 \\
4
\end{tabular} & $\begin{array}{l}0 \\
0 \\
1 \\
0 \\
0 \\
0 \\
1 \\
1 \\
1 \\
1\end{array}$ & $\begin{array}{r}9 \\
7 \\
4 \\
4 \\
6 \\
7 \\
20 \\
18 \\
14 \\
3\end{array}$ & $\begin{array}{r}10 \\
10 \\
6 \\
6 \\
9 \\
9 \\
29 \\
25 \\
17 \\
5\end{array}$ & $\begin{array}{l}0 \\
0 \\
1 \\
0 \\
0 \\
0 \\
2 \\
2 \\
1 \\
1\end{array}$ & $\begin{array}{r}10 \\
10 \\
5 \\
6 \\
9 \\
9 \\
27 \\
23 \\
16 \\
4\end{array}$ & $\begin{array}{r}0.00 \\
.00 \\
16.67 \\
.00 \\
.00 \\
.00 \\
6.90 \\
8.00 \\
5.88 \\
20.00\end{array}$ & $\begin{array}{r}100.00 \\
100.00 \\
83.33 \\
100.00 \\
100.00 \\
100.00 \\
93.10 \\
92.00 \\
94.12 \\
80.00\end{array}$ \\
\hline $\begin{array}{c}\text { Tota } 1, \\
\text { trees } 1- \\
10 \ldots .\end{array}$ & 29 & 2 & 27 & 97 & 5 & 92 & 126 & 7 & 119 & 5.56 & 94.44 \\
\hline
\end{tabular}

TABLE XXIII.-Comparison of number of worms entering fruit at calyx, and at side and stem. Plat II, sprayed A pril 9 and May 2, being first and second spraying as given Plat I, Walnut Creek, Cal., 1910.

\begin{tabular}{|c|c|c|c|c|c|c|c|c|c|c|c|}
\hline \multirow[b]{2}{*}{ Tree No. } & \multicolumn{3}{|c|}{$\begin{array}{l}\text { Worms in windfallen } \\
\text { fruit. }\end{array}$} & \multicolumn{3}{|c|}{$\begin{array}{l}\text { Worms in fruit from } \\
\text { trees. }\end{array}$} & \multicolumn{3}{|c|}{ Total number of-- } & \multicolumn{2}{|c|}{ Percentage of- } \\
\hline & $\begin{array}{l}\text { Num- } \\
\text { ber of } \\
\text { worms. }\end{array}$ & $\begin{array}{c}\text { En- } \\
\text { tered } \\
\text { at } \\
\text { calyx. }\end{array}$ & $\begin{array}{l}\text { En- } \\
\text { tered } \\
\text { at side } \\
\text { and } \\
\text { stem. }\end{array}$ & $\begin{array}{l}\text { Num- } \\
\text { ber of } \\
\text { worms. }\end{array}$ & $\begin{array}{c}\text { En- } \\
\text { tered } \\
\text { at } \\
\text { calyx. }\end{array}$ & $\begin{array}{l}\text { En- } \\
\text { tered } \\
\text { at side } \\
\text { and } \\
\text { stem. }\end{array}$ & Worms. & $\begin{array}{c}\text { Worms } \\
\text { entered } \\
\text { at } \\
\text { calyx. }\end{array}$ & $\begin{array}{c}\text { Worms } \\
\text { entered } \\
\text { at side } \\
\text { and } \\
\text { stem. }\end{array}$ & $\begin{array}{l}\text { Worms } \\
\text { entered } \\
\text { at } \\
\text { calyx. }\end{array}$ & $\begin{array}{l}\text { Worms } \\
\text { entered } \\
\text { at side } \\
\text { and } \\
\text { stem. }\end{array}$ \\
\hline 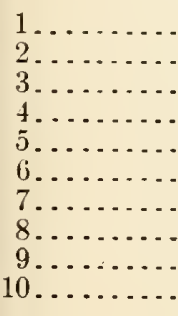 & $\begin{array}{l}2 \\
2 \\
2 \\
2 \\
6 \\
2 \\
6 \\
4 \\
2 \\
2\end{array}$ & $\begin{array}{l}2 \\
1 \\
1 \\
0 \\
2 \\
2 \\
1 \\
1 \\
2 \\
0 \\
0\end{array}$ & $\begin{array}{l}0 \\
1 \\
1 \\
2 \\
4 \\
0 \\
5 \\
2 \\
2 \\
2\end{array}$ & $\begin{array}{l}32 \\
56 \\
21 \\
37 \\
41 \\
43 \\
41 \\
60 \\
75 \\
36\end{array}$ & $\begin{array}{l}2 \\
2 \\
2 \\
0 \\
0 \\
4 \\
6 \\
1 \\
2 \\
1 \\
3\end{array}$ & $\begin{array}{l}30 \\
54 \\
21 \\
37 \\
37 \\
37 \\
40 \\
58 \\
74 \\
33\end{array}$ & $\begin{array}{l}34 \\
58 \\
23 \\
39 \\
47 \\
45 \\
47 \\
64 \\
77 \\
38\end{array}$ & $\begin{array}{l}4 \\
3 \\
1 \\
0 \\
6 \\
8 \\
2 \\
4 \\
1 \\
3\end{array}$ & \begin{tabular}{l|}
30 \\
55 \\
22 \\
39 \\
41 \\
37 \\
45 \\
60 \\
76 \\
35
\end{tabular} & $\begin{array}{r}11.76 \\
5.17 \\
4.35 \\
.00 \\
12.77 \\
17.78 \\
4.26 \\
6.25 \\
1.30 \\
7.90\end{array}$ & $\begin{array}{r}88.24 \\
94.83 \\
95.65 \\
100.00 \\
87.23 \\
82.22 \\
95.74 \\
93.75 \\
98.70 \\
92.10\end{array}$ \\
\hline $\begin{array}{c}\text { Tot a } 1, \\
\text { trees } 1- \\
10 \ldots . .\end{array}$ & 30 & 11 & 19 & 442 & 21 & 421 & 472 & 32 & 440 & 6.79 & 93.21 \\
\hline
\end{tabular}

TABLE XXIV.-Comparison of number of worms entering fruit at calyx and at side and stem. Plat III, sprayed A pril 9 and July 4, being first and third applications as given Plat I, Walnut Creek, Cal., 1910.

\begin{tabular}{|c|c|c|c|c|c|c|c|c|c|c|c|}
\hline \multirow[b]{2}{*}{ Tree No. } & \multicolumn{3}{|c|}{$\begin{array}{l}\text { Worms in windfallen } \\
\text { fruit. }\end{array}$} & \multicolumn{3}{|c|}{$\begin{array}{c}\text { Worms in fruit from } \\
\text { trees. }\end{array}$} & \multicolumn{3}{|c|}{ Total number of- } & \multicolumn{2}{|c|}{ Percentage of- } \\
\hline & $\begin{array}{l}\text { Num- } \\
\text { ber of } \\
\text { worms. }\end{array}$ & $\begin{array}{c}\text { En- } \\
\text { tered } \\
\text { at } \\
\text { calyx. }\end{array}$ & $\begin{array}{l}\text { En- } \\
\text { tered } \\
\text { at side } \\
\text { and } \\
\text { stem. }\end{array}$ & $\begin{array}{l}\text { Num- } \\
\text { ber of } \\
\text { worms. }\end{array}$ & $\begin{array}{c}\text { En- } \\
\text { tered } \\
\text { at } \\
\text { calyx. }\end{array}$ & $\begin{array}{c}\text { En- } \\
\text { tered } \\
\text { at side } \\
\text { and } \\
\text { stem. }\end{array}$ & Worms. & $\begin{array}{c}\text { Worms } \\
\text { entered } \\
\text { at } \\
\text { calyx. }\end{array}$ & $\begin{array}{l}\text { Worms } \\
\text { entered } \\
\text { at side } \\
\text { and } \\
\text { stem. }\end{array}$ & $\begin{array}{l}\text { Worms } \\
\text { entered } \\
\text { at } \\
\text { calyx. }\end{array}$ & $\begin{array}{l}\text { Worms } \\
\text { entered } \\
\text { at side } \\
\text { and } \\
\text { stem. }\end{array}$ \\
\hline $\begin{array}{r}1 \ldots \\
2 \ldots \\
3 \ldots \\
4 \ldots \\
5 \ldots \\
6 \ldots \\
7 \ldots \\
8 \ldots \\
9 \ldots \\
10 \ldots\end{array}$ & $\begin{array}{r}14 \\
11 \\
10 \\
9 \\
17 \\
9 \\
19 \\
9 \\
11 \\
22\end{array}$ & $\begin{array}{r}5 \\
3 \\
1 \\
4 \\
7 \\
4 \\
9 \\
3 \\
4 \\
15\end{array}$ & $\begin{array}{r}9 \\
8 \\
9 \\
5 \\
10 \\
5 \\
10 \\
6 \\
7 \\
7\end{array}$ & $\begin{array}{l}45 \\
38 \\
23 \\
24 \\
66 \\
20 \\
53 \\
15 \\
16 \\
75\end{array}$ & $\begin{array}{r}14 \\
6 \\
3 \\
1 \\
11 \\
3 \\
11 \\
4 \\
3 \\
28\end{array}$ & $\begin{array}{l}31 \\
32 \\
20 \\
23 \\
55 \\
17 \\
42 \\
11 \\
13 \\
47\end{array}$ & $\begin{array}{r}59 \\
49 \\
33 \\
33 \\
83 \\
29 \\
72 \\
24 \\
27 \\
97\end{array}$ & $\begin{array}{r}19 \\
9 \\
4 \\
5 \\
18 \\
7 \\
20 \\
7 \\
7 \\
43\end{array}$ & $\begin{array}{l}40 \\
40 \\
29 \\
28 \\
65 \\
22 \\
52 \\
17 \\
20 \\
54\end{array}$ & $\begin{array}{l}32.21 \\
18.37 \\
12.12 \\
15.15 \\
21.69 \\
24.14 \\
27.78 \\
29.18 \\
25.93 \\
44.33\end{array}$ & $\begin{array}{l}67.79 \\
81.63 \\
87.88 \\
84.85 \\
78.31 \\
75.86 \\
72.22 \\
70.82 \\
74.07 \\
55.67\end{array}$ \\
\hline $\begin{array}{r}\text { Total, } \\
\text { trees } 1- \\
10 \ldots . .\end{array}$ & 131 & 55 & 76 & 375 & 84 & 291 & 506 & 139 & 367 & 27.47 & 72.53 \\
\hline
\end{tabular}


TABLE XXV.-Comparison of number of worms entering pears at calyx, and at side and stem. Plat IV, sprayed May 2 and July 4, being second and third applications as given Plat I, Walnut Creek, Cal., 1910.

\begin{tabular}{|c|c|c|c|c|c|c|c|c|c|c|c|}
\hline \multirow[b]{2}{*}{ Tree No. } & \multicolumn{3}{|c|}{$\begin{array}{l}\text { Worms in windfallen } \\
\text { fruit. }\end{array}$} & \multicolumn{3}{|c|}{$\begin{array}{l}\text { Worms in fruit from } \\
\text { trees. }\end{array}$} & \multicolumn{3}{|c|}{ Total number of- } & \multicolumn{2}{|c|}{ Percentage of- } \\
\hline & $\begin{array}{l}\text { Num- } \\
\text { ber of } \\
\text { worms. }\end{array}$ & $\begin{array}{c}\text { En- } \\
\text { tered } \\
\text { at } \\
\text { calyx. }\end{array}$ & $\begin{array}{c}\text { En- } \\
\text { tered } \\
\text { at side } \\
\text { and } \\
\text { stem. }\end{array}$ & $\begin{array}{l}\text { Num- } \\
\text { ber of } \\
\text { worms. }\end{array}$ & $\begin{array}{c}\text { En- } \\
\text { tered } \\
\text { at } \\
\text { calyx. }\end{array}$ & $\begin{array}{c}\text { En- } \\
\text { tered } \\
\text { at side } \\
\text { and } \\
\text { stem. }\end{array}$ & Worms. & $\begin{array}{l}\text { Worms } \\
\text { entered } \\
\text { at } \\
\text { calyx. }\end{array}$ & $\begin{array}{l}\text { Worms } \\
\text { entered } \\
\text { at side } \\
\text { and } \\
\text { stem. }\end{array}$ & $\begin{array}{c}\text { Worms } \\
\text { entered } \\
\text { at } \\
\text { calyx. }\end{array}$ & $\begin{array}{l}\text { Worms } \\
\text { entered } \\
\text { at side } \\
\text { and } \\
\text { stem. }\end{array}$ \\
\hline $\begin{array}{c}1 \ldots . \\
2 \ldots . \\
3 \ldots \\
4 \ldots \\
5 \ldots . \\
6 \ldots \\
7 \ldots . \\
8 \ldots \\
9 \ldots . \\
10 \ldots \\
\end{array}$ & $\begin{array}{l}21 \\
39 \\
49 \\
35 \\
15 \\
24 \\
26 \\
14 \\
11 \\
13\end{array}$ & $\begin{array}{r}10 \\
32 \\
39 \\
26 \\
10 \\
20 \\
17 \\
8 \\
9 \\
6\end{array}$ & $\begin{array}{r}11 \\
7 \\
10 \\
9 \\
5 \\
4 \\
9 \\
6 \\
2 \\
7\end{array}$ & $\begin{array}{l}80 \\
78 \\
87 \\
89 \\
21 \\
88 \\
82 \\
52 \\
66 \\
32\end{array}$ & $\begin{array}{l}37 \\
40 \\
31 \\
38 \\
13 \\
37 \\
27 \\
26 \\
32 \\
18\end{array}$ & $\begin{array}{r}43 \\
38 \\
56 \\
51 \\
8 \\
51 \\
55 \\
26 \\
34 \\
14\end{array}$ & $\begin{array}{r}101 \\
117 \\
136 \\
124 \\
36 \\
112 \\
108 \\
66 \\
77 \\
45\end{array}$ & $\begin{array}{l}47 \\
72 \\
70 \\
64 \\
23 \\
57 \\
44 \\
34 \\
41 \\
24\end{array}$ & $\begin{array}{l}54 \\
45 \\
66 \\
60 \\
13 \\
55 \\
64 \\
32 \\
36 \\
21\end{array}$ & & $\begin{array}{l}53.46 \\
38.46 \\
48.53 \\
48.39 \\
36.11 \\
49.11 \\
59.26 \\
48.48 \\
46.75 \\
46.67\end{array}$ \\
\hline $\begin{array}{c}\text { Tota } 1, \\
\text { trees } 1- \\
10 \ldots . .\end{array}$ & 247 & 177 & 70 & 675 & 299 & 376 & 922 & 476 & 446 & 51.63 & 48.37 \\
\hline
\end{tabular}

TABLE XXVI.-Comparison of number of worms entering pears at calyx, and at side and stem. Plat V, sprayed July 4, being third application as given Plat I, Walnut Creek, Cal., 1910.

\begin{tabular}{|c|c|c|c|c|c|c|c|c|c|c|c|}
\hline \multirow[b]{2}{*}{ 'Tree No. } & \multicolumn{3}{|c|}{$\begin{array}{l}\text { Worms in windfallen } \\
\text { fruit. }\end{array}$} & \multicolumn{3}{|c|}{$\begin{array}{l}\text { Worms in fruit from } \\
\text { trees. }\end{array}$} & \multicolumn{3}{|c|}{ Total number of- } & \multicolumn{2}{|c|}{ Percentage of- } \\
\hline & $\begin{array}{l}\text { Num- } \\
\text { ber of } \\
\text { worms. }\end{array}$ & $\begin{array}{l}\text { En- } \\
\text { tered } \\
\text { at } \\
\text { calyx. }\end{array}$ & $\begin{array}{c}\text { En- } \\
\text { tered } \\
\text { at side } \\
\text { and } \\
\text { stem. }\end{array}$ & $\begin{array}{l}\text { Num- } \\
\text { ber of } \\
\text { worms. }\end{array}$ & $\begin{array}{c}\text { En- } \\
\text { tered } \\
\text { at } \\
\text { calyx. }\end{array}$ & $\begin{array}{c}\text { En- } \\
\text { tered } \\
\text { at side } \\
\text { and } \\
\text { stem. }\end{array}$ & Torms. & $\begin{array}{c}\text { Worms } \\
\text { entered } \\
\text { at } \\
\text { calyx. }\end{array}$ & $\begin{array}{l}\text { Worms } \\
\text { entered } \\
\text { at side } \\
\text { and } \\
\text { stem. }\end{array}$ & $\begin{array}{c}\text { Worms } \\
\text { entered } \\
\text { at } \\
\text { calyx. }\end{array}$ & $\begin{array}{l}\text { Worms } \\
\text { entered } \\
\text { at side } \\
\text { and } \\
\text { stem. }\end{array}$ \\
\hline $\begin{array}{c}1 \ldots \\
2 \ldots \\
3 \ldots \\
4 \ldots \\
5 \ldots \\
6 \ldots \\
7 \ldots \\
8 \ldots \\
9 \ldots \\
10 \ldots\end{array}$ & $\begin{array}{r}78 \\
132 \\
80 \\
84 \\
116 \\
108 \\
218 \\
82 \\
83 \\
41\end{array}$ & $\begin{array}{r}74 \\
120 \\
74 \\
76 \\
104 \\
96 \\
197 \\
75 \\
74 \\
37\end{array}$ & $\begin{array}{r}4 \\
12 \\
6 \\
8 \\
12 \\
12 \\
21 \\
7 \\
9 \\
4\end{array}$ & $\begin{array}{r}89 \\
112 \\
59 \\
56 \\
116 \\
94 \\
198 \\
83 \\
89 \\
58\end{array}$ & $\begin{array}{r}68 \\
83 \\
44 \\
48 \\
102 \\
84 \\
162 \\
73 \\
71 \\
41\end{array}$ & $\begin{array}{r}21 \\
29 \\
15 \\
8 \\
14 \\
10 \\
36 \\
10 \\
18\end{array}$ & $\begin{array}{r}167 \\
244 \\
139 \\
140 \\
232 \\
202 \\
416 \\
165 \\
172 \\
99\end{array}$ & $\begin{array}{r}118 \\
124 \\
206 \\
180 \\
359 \\
148 \\
145 \\
78\end{array}$ & $\begin{array}{l}25 \\
41 \\
21 \\
16 \\
26 \\
22 \\
57 \\
17 \\
27 \\
21\end{array}$ & & $\begin{array}{l}14.97 \\
16.80 \\
15.11 \\
11.43 \\
11.21 \\
10.89 \\
13.70 \\
10.31 \\
15.70 \\
21.21\end{array}$ \\
\hline $\begin{array}{c}\text { Tota } 1, \\
\text { trees } 1- \\
10 \ldots . .\end{array}$ & 1,022 & 927 & 95 & $95 \overline{4}$ & 776 & 178 & 1,976 & 1,703 & 273 & 86.18 & 13.82 \\
\hline
\end{tabular}

TABLE XXVII.-Comparison of number of worms entering pears at calyx, and at side and stem. Plat VI, unsprayed check, Walnut Creek, Cal., 1910.

\begin{tabular}{|c|c|c|c|c|c|c|c|c|c|c|c|}
\hline \multirow[b]{2}{*}{ Tree No. } & \multicolumn{3}{|c|}{$\begin{array}{l}\text { Worms in windfallen } \\
\text { fruit. }\end{array}$} & \multicolumn{3}{|c|}{$\begin{array}{l}\text { Wrorms in fruit from } \\
\text { trees. }\end{array}$} & \multicolumn{3}{|c|}{ Total number of- } & \multicolumn{2}{|c|}{ Percentage of- } \\
\hline & $\begin{array}{l}\text { Num- } \\
\text { ber of } \\
\text { worms. }\end{array}$ & $\begin{array}{l}\text { En- } \\
\text { tered } \\
\text { at } \\
\text { calyx. }\end{array}$ & $\begin{array}{l}\text { En- } \\
\text { tered } \\
\text { at side } \\
\text { and } \\
\text { stem. }\end{array}$ & $\begin{array}{l}\text { Num- } \\
\text { ber of } \\
\text { worms. }\end{array}$ & $\begin{array}{l}\text { En- } \\
\text { tered } \\
\text { at } \\
\text { calyx. }\end{array}$ & $\begin{array}{l}\text { En- } \\
\text { tered } \\
\text { at side } \\
\text { and } \\
\text { stem. }\end{array}$ & Worms. & $\begin{array}{l}\text { Worms } \\
\text { entered } \\
\text { at } \\
\text { calyx. }\end{array}$ & $\begin{array}{l}\text { Worms } \\
\text { entered } \\
\text { at side } \\
\text { and } \\
\text { stem. }\end{array}$ & $\begin{array}{l}\text { Worms } \\
\text { entered } \\
\text { at } \\
\text { calyx. }\end{array}$ & $\begin{array}{l}\text { Worms } \\
\text { entered } \\
\text { at side } \\
\text { and } \\
\text { stem. }\end{array}$ \\
\hline $\begin{array}{r}1 \ldots \\
2 \ldots \\
3 \ldots \\
4 \ldots \\
5 \ldots \\
6 \ldots \\
7 \ldots \\
8 \ldots \\
9 \ldots \\
10 \ldots\end{array}$ & $\begin{array}{r}192 \\
119 \\
181 \\
139 \\
95 \\
119 \\
58 \\
105 \\
119 \\
118\end{array}$ & $\begin{array}{r}181 \\
106 \\
165 \\
123 \\
86 \\
106 \\
54 \\
89 \\
104 \\
105\end{array}$ & $\begin{array}{r}11 \\
13 \\
16 \\
16 \\
9 \\
13 \\
4 \\
16 \\
15 \\
13\end{array}$ & $\begin{array}{r}153 \\
91 \\
134 \\
119 \\
84 \\
52 \\
95 \\
97 \\
134 \\
75\end{array}$ & $\begin{array}{r}146 \\
77 \\
131 \\
112 \\
78 \\
47 \\
79 \\
91 \\
130 \\
70\end{array}$ & $\begin{array}{r}7 \\
14 \\
3 \\
7 \\
6 \\
5 \\
16 \\
6 \\
4 \\
5\end{array}$ & $\begin{array}{l}315 \\
258 \\
179 \\
171 \\
153 \\
202 \\
253 \\
193\end{array}$ & $\begin{array}{l}327 \\
183 \\
296 \\
235 \\
164 \\
153 \\
133 \\
180 \\
234 \\
175\end{array}$ & $\begin{array}{l}18 \\
27 \\
19 \\
23 \\
15 \\
18 \\
20 \\
22 \\
19 \\
18\end{array}$ & $\begin{array}{l}92.50 \\
90.67\end{array}$ & $\begin{array}{r}5.22 \\
12.86 \\
6.03 \\
8.92 \\
8.40 \\
10.52 \\
13.07 \\
10.90 \\
7.50 \\
9.33\end{array}$ \\
\hline $\begin{array}{c}\text { Tot a } 1, \\
\text { trees } 1- \\
10 . . .\end{array}$ & 1,245 & 1,119 & 126 & 1,034 & 961 & 73 & 2,279 & 2,080 & 199 & 91.27 & 8. 73 \\
\hline
\end{tabular}


TABLE XXVIII.-Comparison of number of worms entering pears at calyx, and at side and stem. Plat VII, sprayed April 9, being first application as given Plat I, Walnut Creek, Cal., 1910.

\begin{tabular}{|c|c|c|c|c|c|c|c|c|c|c|c|}
\hline \multirow[b]{2}{*}{ Tree No. } & \multicolumn{3}{|c|}{$\begin{array}{l}\text { Worms in windfallen } \\
\text { fruit. }\end{array}$} & \multicolumn{3}{|c|}{$\begin{array}{l}\text { Worms in fruit from " } \\
\text { trees. }\end{array}$} & \multicolumn{3}{|c|}{ Total number of- } & \multicolumn{2}{|c|}{ Percentage of- } \\
\hline & $\begin{array}{l}\text { Num- } \\
\text { ber of } \\
\text { worms. }\end{array}$ & $\begin{array}{l}\text { En- } \\
\text { tered at } \\
\text { calyx. }\end{array}$ & $\begin{array}{l}\text { En- } \\
\text { tered } \\
\text { at side } \\
\text { and } \\
\text { stem. }\end{array}$ & $\begin{array}{l}\text { Num- } \\
\text { ber of } \\
\text { worms. }\end{array}$ & $\begin{array}{l}\text { Fn- } \\
\text { tered at } \\
\text { calyx. }\end{array}$ & $\begin{array}{l}\text { En- } \\
\text { tered } \\
\text { at side } \\
\text { and } \\
\text { stem. }\end{array}$ & Worins. & $\begin{array}{c}\text { Worms } \\
\text { entered } \\
\text { at } \\
\text { calyx. }\end{array}$ & $\begin{array}{c}\text { Worms } \\
\text { entered } \\
\text { at side } \\
\text { and } \\
\text { stem. }\end{array}$ & $\begin{array}{l}\text { Worms } \\
\text { entered } \\
\text { at } \\
\text { calyx. }\end{array}$ & $\begin{array}{l}\text { Worms } \\
\text { entered } \\
\text { at side } \\
\text { and } \\
\text { stem. }\end{array}$ \\
\hline $\begin{array}{r}1 \ldots \ldots \\
2 \ldots \ldots \\
3 \ldots \ldots \\
4 \ldots \ldots \\
5 \ldots \ldots \\
6 \ldots \ldots \\
8 \ldots \ldots \\
9 \ldots \ldots \\
10 \ldots \ldots \\
\ldots \ldots \\
\ldots\end{array}$ & $\begin{array}{r}15 \\
6 \\
10 \\
21 \\
7 \\
9 \\
27 \\
20 \\
6 \\
5\end{array}$ & $\begin{array}{r}7 \\
2 \\
5 \\
9 \\
2 \\
4 \\
8 \\
11 \\
1 \\
3\end{array}$ & $\begin{array}{r}8 \\
4 \\
5 \\
12 \\
5 \\
5 \\
5 \\
19 \\
9 \\
5 \\
2\end{array}$ & \begin{tabular}{r|}
26 \\
32 \\
88 \\
54 \\
52 \\
116 \\
75 \\
42 \\
45 \\
37
\end{tabular} & \begin{tabular}{r|r}
8 \\
8 \\
15 \\
8 \\
10 \\
15 \\
49 \\
7 \\
9 \\
11
\end{tabular} & $\begin{array}{r}18 \\
24 \\
73 \\
46 \\
42 \\
101 \\
26 \\
35 \\
36 \\
26\end{array}$ & $\begin{array}{r}41 \\
38 \\
98 \\
75 \\
59 \\
125 \\
102 \\
62 \\
51 \\
42\end{array}$ & $\begin{array}{l}15 \\
10 \\
20 \\
17 \\
12 \\
19 \\
57 \\
18 \\
10 \\
14\end{array}$ & $\begin{array}{r}26 \\
28 \\
78 \\
58 \\
47 \\
106 \\
45 \\
44 \\
41 \\
28\end{array}$ & $\begin{array}{l}36.59 \\
26.33 \\
20.41 \\
22.67 \\
20.34 \\
15.20 \\
55.88 \\
29.19 \\
19.61 \\
33.33\end{array}$ & $\begin{array}{l}63.41 \\
73.67 \\
79.59 \\
77.33 \\
79.66 \\
84.80 \\
44.12 \\
70.81 \\
80.39 \\
66.67\end{array}$ \\
\hline $\begin{array}{c}\mathrm{T} \text { ot a l, } \\
\text { trees } 1- \\
10 . . .\end{array}$ & 126 & 52 & 74 & 567 & 140 & 427 & 693 & 192 & 501 & 27.71 & 72.29 \\
\hline
\end{tabular}

TABLE XXIX.-Comparison of number of worms entering pears at calyx, and at side and stem. Plat VIII, sprayed May 2, being second application as given Plat I, Walnut Creek, Cal., 1910.

\begin{tabular}{|c|c|c|c|c|c|c|c|c|c|c|c|}
\hline \multirow[b]{2}{*}{ Tree No. } & \multicolumn{3}{|c|}{$\begin{array}{l}\text { Worms in windfallen } \\
\text { fruit. }\end{array}$} & \multicolumn{3}{|c|}{$\begin{array}{l}\text { Worms in fruit from } \\
\text { trees. }\end{array}$} & \multicolumn{3}{|c|}{ Total number of - } & \multicolumn{2}{|c|}{ Percentage of- } \\
\hline & $\begin{array}{l}\text { Num- } \\
\text { ber of } \\
\text { worms. }\end{array}$ & $\begin{array}{l}\text { En- } \\
\text { tered at } \\
\text { calyx. }\end{array}$ & $\begin{array}{c}\text { En- } \\
\text { tered } \\
\text { at side } \\
\text { and } \\
\text { stem. }\end{array}$ & $\begin{array}{l}\text { Num- } \\
\text { ber of } \\
\text { worms. }\end{array}$ & $\begin{array}{l}\text { Fn- } \\
\text { tered at } \\
\text { calyx. }\end{array}$ & $\begin{array}{l}\text { En- } \\
\text { tered } \\
\text { at side } \\
\text { and } \\
\text { stem. }\end{array}$ & Worms. & $\begin{array}{c}\text { Worms } \\
\text { entered } \\
\text { at } \\
\text { calyx. }\end{array}$ & $\begin{array}{c}\text { Worms } \\
\text { enterer } \\
\text { at side } \\
\text { and } \\
\text { stem. }\end{array}$ & $\begin{array}{l}\text { Worms } \\
\text { entered } \\
\text { at } \\
\text { calyx. }\end{array}$ & $\begin{array}{l}\text { Worms } \\
\text { entered } \\
\text { at side } \\
\text { and } \\
\text { stem. }\end{array}$ \\
\hline $\begin{array}{c}1 \ldots \\
2 \ldots \\
3 \ldots \\
4 \ldots \\
5 \ldots \\
6 \ldots \\
7 \ldots \\
8 \ldots \\
9 \ldots \\
10 \ldots\end{array}$ & $\begin{array}{l}1 \\
31 \\
10 \\
29 \\
21 \\
82 \\
20 \\
19 \\
28 \\
19\end{array}$ & $\begin{array}{r}1 \\
22 \\
8 \\
24 \\
15 \\
50 \\
11 \\
13 \\
20 \\
10\end{array}$ & $\begin{array}{r}9 \\
2 \\
5 \\
6 \\
32 \\
9 \\
6 \\
8 \\
9\end{array}$ & $\begin{array}{r}19 \\
70 \\
42 \\
116 \\
29 \\
119 \\
53 \\
39 \\
64 \\
46\end{array}$ & $\begin{array}{r}4 \\
32 \\
12 \\
53 \\
10 \\
43 \\
24 \\
16 \\
25 \\
20\end{array}$ & $\begin{array}{l}15 \\
38 \\
30 \\
63 \\
19 \\
76 \\
29 \\
23 \\
39 \\
26\end{array}$ & $\begin{array}{r}20 \\
101 \\
52 \\
145 \\
50 \\
201 \\
73 \\
58 \\
92 \\
65\end{array}$ & $\begin{array}{r}5 \\
54 \\
20 \\
77 \\
25 \\
93 \\
35 \\
29 \\
45 \\
30\end{array}$ & $\begin{array}{r}15 \\
47 \\
32 \\
68 \\
25 \\
108 \\
38 \\
29 \\
47 \\
35\end{array}$ & $\begin{array}{l}25.00 \\
48.65 \\
38.46 \\
53.10 \\
50.00 \\
46.27 \\
47.95 \\
50.00 \\
48.91 \\
46.15\end{array}$ & $\begin{array}{l}75.00 \\
51.35 \\
61.54 \\
46.90 \\
50.00 \\
53.73 \\
52.05 \\
50.00 \\
51.09 \\
53.85\end{array}$ \\
\hline $\begin{array}{c}\text { T o t a l, } \\
\text { trees 1- } \\
10 \ldots . .\end{array}$ & 260 & 174 & 86 & 597 & 239 & 358 & 857 & 413 & 444 & 48.19 & 51.81 \\
\hline
\end{tabular}

TABLE XXX.- Comparison of number of worms entering fruit at calyx, and at side and stem. Plat I, sprayed three times, Suisun, Cal., 1910.

\begin{tabular}{|c|c|c|c|c|c|c|c|c|c|c|c|}
\hline \multirow[b]{2}{*}{ Tree No. } & \multicolumn{3}{|c|}{$\begin{array}{l}\text { Worms in windfallen } \\
\text { fruit. }\end{array}$} & \multicolumn{3}{|c|}{$\begin{array}{l}\text { Worms in fruit from } \\
\text { trees. }\end{array}$} & \multicolumn{3}{|c|}{ Total number of-- } & \multicolumn{2}{|c|}{ Percentage of- } \\
\hline & $\begin{array}{l}\text { Num- } \\
\text { ber of } \\
\text { worms. }\end{array}$ & $\begin{array}{c}\text { En- } \\
\text { tered at } \\
\text { calyx. }\end{array}$ & $\begin{array}{l}\text { Fn- } \\
\text { tered } \\
\text { at side } \\
\text { and } \\
\text { stem. }\end{array}$ & $\begin{array}{l}\text { Num- } \\
\text { ber of } \\
\text { worms. }\end{array}$ & $\begin{array}{c}\text { En- } \\
\text { tered at } \\
\text { calyx. }\end{array}$ & $\begin{array}{c}\text { En- } \\
\text { tered } \\
\text { at side } \\
\text { and } \\
\text { stem. }\end{array}$ & Worms. & $\begin{array}{c}\text { W orms } \\
\text { entered } \\
\text { at } \\
\text { calyx. }\end{array}$ & $\begin{array}{c}\text { Worms } \\
\text { entered } \\
\text { at side } \\
\text { and } \\
\text { stem. }\end{array}$ & $\begin{array}{c}\text { Worms } \\
\text { entered } \\
\text { at } \\
\text { calyx. }\end{array}$ & $\begin{array}{l}\text { Worms } \\
\text { entered } \\
\text { at side } \\
\text { and } \\
\text { stem. }\end{array}$ \\
\hline $\begin{array}{c}1 \ldots \ldots \\
2 \ldots \ldots \\
3 \ldots \ldots \\
4 \ldots \\
5 \ldots \ldots \\
6 \ldots \ldots \\
7 \ldots \ldots \\
8 \ldots \ldots \\
9 \ldots \ldots \\
10 \ldots \ldots \\
\ldots \ldots \\
\ldots\end{array}$ & $\begin{array}{r}19 \\
8 \\
6 \\
6 \\
14 \\
12 \\
22 \\
30 \\
13 \\
29\end{array}$ & $\begin{array}{r}9 \\
4 \\
2 \\
1 \\
7 \\
5 \\
8 \\
10 \\
4 \\
16\end{array}$ & $\begin{array}{r}10 \\
4 \\
4 \\
5 \\
7 \\
7 \\
14 \\
20 \\
9 \\
13\end{array}$ & $\begin{array}{r}36 \\
15 \\
11 \\
16 \\
12 \\
9 \\
37 \\
39 \\
30 \\
59\end{array}$ & $\begin{array}{r}7 \\
4 \\
4 \\
1 \\
3 \\
0 \\
8 \\
14 \\
7 \\
16\end{array}$ & $\begin{array}{r}29 \\
11 \\
7 \\
15 \\
9 \\
9 \\
29 \\
25 \\
23 \\
43\end{array}$ & $\begin{array}{l}55 \\
23 \\
17 \\
22 \\
26 \\
21 \\
59 \\
69 \\
43 \\
88\end{array}$ & $\begin{array}{r}16 \\
8 \\
6 \\
2 \\
10 \\
5 \\
16 \\
24 \\
11 \\
32\end{array}$ & $\begin{array}{l}39 \\
15 \\
11 \\
20 \\
16 \\
16 \\
43 \\
45 \\
32 \\
56\end{array}$ & $\begin{array}{r}29.09 \\
34.78 \\
35.29 \\
9.09 \\
38.46 \\
23.81 \\
27.12 \\
34.78 \\
25.58 \\
36.36\end{array}$ & $\begin{array}{l}70.91 \\
65.22 \\
64.71 \\
90.91 \\
61.54 \\
76.19 \\
72.88 \\
65.22 \\
74.42 \\
63.64\end{array}$ \\
\hline $\begin{array}{c}\text { Tota } 1, \\
\text { trees } 1- \\
10 \ldots . . .\end{array}$ & 159 & 66 & 93 & 264 & 64 & 200 & 423 & 130 & 293 & 30.73 & 69.27 \\
\hline
\end{tabular}


TABIE XXXI.-Comparison of number of worms entering pears at calyx, and at side and stem. Plat II, sprayed May 5 and June 16. being second and third applications as given Plat I. Suisun, Cal., 1910.

\begin{tabular}{|c|c|c|c|c|c|c|c|c|c|c|c|}
\hline \multirow[b]{2}{*}{ Tree No. } & \multicolumn{3}{|c|}{$\begin{array}{l}\text { Worms in windfallen } \\
\text { fruit. }\end{array}$} & \multicolumn{3}{|c|}{$\begin{array}{l}\text { Worms in fruit from } \\
\text { trees. }\end{array}$} & \multicolumn{3}{|c|}{ Total number of- } & \multicolumn{2}{|c|}{ Percentage of- } \\
\hline & $\begin{array}{l}\text { Num- } \\
\text { ber of } \\
\text { worms. }\end{array}$ & $\begin{array}{l}\text { En- } \\
\text { tered at } \\
\text { calyx. }\end{array}$ & $\begin{array}{l}\text { En- } \\
\text { tered } \\
\text { at side } \\
\text { and } \\
\text { stem. }\end{array}$ & $\begin{array}{l}\text { Num- } \\
\text { ber of } \\
\text { worms. }\end{array}$ & $\begin{array}{c}\text { En- } \\
\text { tered at } \\
\text { calyx. }\end{array}$ & $\begin{array}{l}\text { En- } \\
\text { tered } \\
\text { at side } \\
\text { and } \\
\text { stem. }\end{array}$ & Worms. & $\begin{array}{c}\text { Torms } \\
\text { entered } \\
\text { at } \\
\text { calpx. }\end{array}$ & $\begin{array}{l}\text { Worms } \\
\text { entered } \\
\text { at side } \\
\text { and } \\
\text { stem. }\end{array}$ & $\begin{array}{l}\text { Worms } \\
\text { entered } \\
\text { at } \\
\text { calvx. }\end{array}$ & $\begin{array}{l}\text { Worms } \\
\text { entered } \\
\text { at side } \\
\text { and } \\
\text { stem. }\end{array}$ \\
\hline 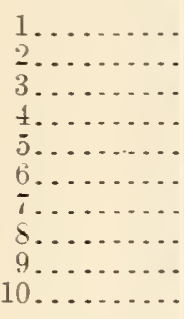 & $\begin{array}{r}57 \\
95 \\
72 \\
51 \\
76 \\
149 \\
74 \\
114 \\
34 \\
103\end{array}$ & \begin{tabular}{r|}
40 \\
66 \\
55 \\
42 \\
60 \\
114 \\
47 \\
83 \\
27 \\
78
\end{tabular} & $\begin{array}{r}17 \\
29 \\
17 \\
9 \\
17 \\
35 \\
27 \\
31 \\
7 \\
25\end{array}$ & $\begin{array}{r}56 \\
123 \\
130 \\
52 \\
107 \\
1 \pm 9 \\
76 \\
140 \\
67 \\
139\end{array}$ & $\begin{array}{r}34 \\
82 \\
84 \\
31 \\
75 \\
92 \\
50 \\
101 \\
37 \\
62\end{array}$ & $\begin{array}{l}22 \\
41 \\
46 \\
21 \\
32 \\
57 \\
26 \\
39 \\
30 \\
77\end{array}$ & $\begin{array}{l}113 \\
218 \\
202 \\
103 \\
184 \\
298 \\
150 \\
254 \\
101 \\
2 \pm 2\end{array}$ & $\begin{array}{r}i 4 \\
148 \\
139 \\
73 \\
135 \\
206 \\
97 \\
184 \\
61 \\
140\end{array}$ & $\begin{array}{r}39 \\
70 \\
63 \\
30 \\
49 \\
92 \\
53 \\
70 \\
37 \\
102\end{array}$ & $\begin{array}{l}65.49 \\
67.89 \\
68.81 \\
70.87 \\
73.37 \\
69.13 \\
64.67 \\
72.44 \\
63.37 \\
57.85\end{array}$ & $\begin{array}{l}34.51 \\
67.89 \\
31.19 \\
29.13 \\
26.63 \\
69.85 \\
35.33 \\
27.56 \\
36.63 \\
42.15\end{array}$ \\
\hline $\begin{array}{l}\text { Total, } \\
\text { trees } 1- \\
10 \ldots . .\end{array}$ & \$26 & 612 & 214 & 1,039 & 648 & 391 & $1.86 j$ & 1,260 & 605 & 67.56 & 32.44 \\
\hline
\end{tabular}

TABLE IXXII.-Comparison of number of worms entering pears at calyx, and at side and stem. Plat III, sprayed April $\gamma$ and June $1 \tau$, being first and third applications as given Plat I. Suisun, Cal., 1910.

\begin{tabular}{|c|c|c|c|c|c|c|c|c|c|c|c|}
\hline \multirow[b]{2}{*}{ Tree No. } & \multicolumn{3}{|c|}{$\begin{array}{l}\text { Torms in windfallen } \\
\text { fruit. }\end{array}$} & \multicolumn{3}{|c|}{$\begin{array}{l}\text { Worms in fruit from } \\
\text { trees. }\end{array}$} & \multicolumn{3}{|c|}{ Total number of- } & \multicolumn{2}{|c|}{ Percentage of- } \\
\hline & $\begin{array}{l}\text { Num- } \\
\text { ber of } \\
\text { worms. }\end{array}$ & $\begin{array}{c}\text { En- } \\
\text { tered at } \\
\text { calyx. }\end{array}$ & $\begin{array}{l}\text { En- } \\
\text { tered } \\
\text { at side } \\
\text { and } \\
\text { stem. }\end{array}$ & $\begin{array}{l}\text { Num- } \\
\text { ber of } \\
\text { worms. }\end{array}$ & $\begin{array}{l}\text { En- } \\
\text { tered at } \\
\text { calyx. }\end{array}$ & $\begin{array}{l}\text { En- } \\
\text { tered } \\
\text { at side } \\
\text { and } \\
\text { stem. }\end{array}$ & Torms. & $\begin{array}{c}\text { Torms } \\
\text { entered } \\
\text { at } \\
\text { calyx. }\end{array}$ & $\begin{array}{l}\pi \text { Torms } \\
\text { entered } \\
\text { at side } \\
\text { and } \\
\text { stem. }\end{array}$ & $\begin{array}{l}\text { Torms } \\
\text { entered } \\
\text { at } \\
\text { calyx. }\end{array}$ & $\begin{array}{l}\text { Worms } \\
\text { entered } \\
\text { at side } \\
\text { and } \\
\text { stem. }\end{array}$ \\
\hline 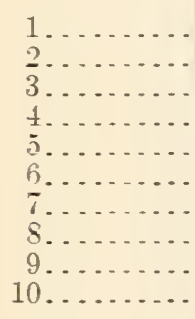 & $\begin{array}{l}25 \\
17 \\
11 \\
13 \\
18 \\
43 \\
59 \\
14 \\
41 \\
20\end{array}$ & \begin{tabular}{r|}
16 \\
8 \\
27 \\
7 \\
9 \\
19 \\
36 \\
19 \\
24 \\
12
\end{tabular} & $\begin{array}{r}9 \\
9 \\
17 \\
6 \\
9 \\
24 \\
23 \\
25 \\
17 \\
8\end{array}$ & $\begin{array}{r}56 \\
36 \\
45 \\
26 \\
34 \\
67 \\
127 \\
91 \\
52 \\
41\end{array}$ & $\begin{array}{r}13 \\
13 \\
18 \\
8 \\
7 \\
26 \\
52 \\
41 \\
15 \\
17\end{array}$ & $\begin{array}{l}43 \\
23 \\
27 \\
18 \\
27 \\
41 \\
75 \\
50 \\
2\end{array}$ & \begin{tabular}{r|}
$\$ 1$ \\
53 \\
$\$ 9$ \\
39 \\
52 \\
110 \\
186 \\
$13 j$ \\
93 \\
61
\end{tabular} & $\begin{array}{l}29 \\
21 \\
45 \\
15 \\
16 \\
45 \\
88 \\
60 \\
39 \\
29\end{array}$ & $\begin{array}{l}52 \\
32 \\
41 \\
24 \\
36 \\
65 \\
98 \\
75\end{array}$ & $\begin{array}{l}35.80 \\
39.63 \\
50.50 \\
38.46 \\
30.77 \\
40.91 \\
47.31 \\
44.44 \\
41.94 \\
47.54\end{array}$ & $\begin{array}{r}64.20 \\
60.37 \\
49.50 \\
61.54 \\
69.23 \\
59.09 \\
52.69 \\
55.56 \\
58.06 \\
52.46\end{array}$ \\
\hline $\begin{array}{c}\text { Tota } 1 \text {, } \\
\text { trees } 1- \\
10 . . .\end{array}$ & 324 & $17 \pi$ & $14 \overline{7}$ & 575 & 210 & 365 & s99 & $3 S t$ & 512 & 43.05 & 56.95 \\
\hline
\end{tabular}

TABLE IXXIII.-Comparison of number of worms entering pears at caly $x$, and at side and stem. Plat IV, unsprayed check, Suisun. Cal., 1910.

\begin{tabular}{|c|c|c|c|c|c|c|c|c|c|c|c|}
\hline \multirow[b]{2}{*}{ Tree No. } & \multicolumn{3}{|c|}{$\begin{array}{l}\text { Torms in windfallen } \\
\text { fruit. }\end{array}$} & \multicolumn{3}{|c|}{$\begin{array}{l}\text { Worms in fruit from } \\
\text { trees. }\end{array}$} & \multicolumn{3}{|c|}{ Total number of- } & \multicolumn{2}{|c|}{ Percentage of- } \\
\hline & $\begin{array}{l}\text { Num- } \\
\text { ber of } \\
\text { worms. }\end{array}$ & $\begin{array}{c}\text { En- } \\
\text { tered at } \\
\text { calyx. }\end{array}$ & $\begin{array}{l}\text { En- } \\
\text { tered } \\
\text { at side } \\
\text { and } \\
\text { stem. }\end{array}$ & $\begin{array}{l}\text { Num- } \\
\text { ber of } \\
\text { worms. }\end{array}$ & $\begin{array}{l}\text { En- } \\
\text { tered at } \\
\text { calyx. }\end{array}$ & $\begin{array}{l}\text { En- } \\
\text { tered } \\
\text { at side } \\
\text { and } \\
\text { stem. }\end{array}$ & Worms. & $\begin{array}{l}\text { Worms } \\
\text { entered } \\
\text { at } \\
\text { calyx. }\end{array}$ & $\begin{array}{l}\text { Worms } \\
\text { entered } \\
\text { at side } \\
\text { and } \\
\text { stem. }\end{array}$ & $\begin{array}{c}\text { Worms } \\
\text { entered } \\
\text { at } \\
\text { calyx. }\end{array}$ & $\begin{array}{l}\text { Worms } \\
\text { entered } \\
\text { at side } \\
\text { and } \\
\text { stem. }\end{array}$ \\
\hline $\begin{array}{c}1 \ldots \\
2 \ldots \\
3 \ldots \\
4 \ldots \\
5 \ldots \\
6 \ldots \\
7 . \\
8 . \\
9 \ldots \\
10 \ldots\end{array}$ & $\begin{array}{l}370 \\
199 \\
420 \\
171 \\
386 \\
248 \\
496 \\
193 \\
533 \\
4 \$ 1\end{array}$ & $\begin{array}{l}188 \\
398 \\
160 \\
359 \\
22 \\
47 \\
179 \\
503 \\
46\end{array}$ & $\begin{array}{l}20 \\
11 \\
22 \\
11 \\
27 \\
21 \\
20 \\
14 \\
30\end{array}$ & $\begin{array}{l}158 \\
118 \\
136 \\
227 \\
326 \\
228 \\
195 \\
107 \\
255 \\
404\end{array}$ & $\begin{array}{l}143 \\
112 \\
123 \\
213 \\
301 \\
219 \\
182 \\
100 \\
234 \\
367\end{array}$ & $\begin{array}{r}15 \\
6 \\
13 \\
14 \\
25 \\
9 \\
13 \\
7 \\
21 \\
37\end{array}$ & $\begin{array}{l}528 \\
317 \\
556 \\
398 \\
712 \\
476 \\
691 \\
300 \\
788 \\
855\end{array}$ & $\begin{array}{l}49 \\
30 \\
52 \\
37 \\
66 \\
11 \\
65 \\
27 \\
73 \\
83\end{array}$ & $\begin{array}{l}35 \\
17 \\
35 \\
25 \\
52 \\
30 \\
33 \\
21 \\
51 \\
51\end{array}$ & $\begin{array}{l}93.37 \\
91.64 \\
93.70 \\
93.72 \\
92.69 \\
93.70 \\
95.22 \\
93.00 \\
93.52 \\
93.90\end{array}$ & $\begin{array}{l}6.63 \\
5.36 \\
6.30 \\
6.28 \\
7.31 \\
6.30 \\
1.78 \\
7.00 \\
6.48 \\
6.10\end{array}$ \\
\hline $\begin{array}{l}\text { Tot a } 1, \\
\text { trees } 1- \\
10 \ldots\end{array}$ & 3,497 & 3,301 & 193 & $2.15 t$ & 1.994 & 160 & 5,651 & 5,296 & 355 & 93.72 & 6.28 \\
\hline
\end{tabular}


To show more fully the results of the different sprayings as influencing the places of entrance of the worms and showing where they are mostly killed Tables XXXIV, XXXV, and XXXVI have been prepared, which are in part summaries of the foregoing tables and of those which are to follow under the heading of "Commercial results from spraying."

In Table XXXIV, in the unsprayed portion, Plat VI, 85.702 per cent of the pears were wormy at the calyx, and 8.198 per cent were wormy at the side and stem, while in the demonstration block, Plat I, which received three sprayings only, 0.223 per cent of the pears were wormy at the calyx and 3.803 per cent at the side and stem. This indicates that the sprayings reduced the infestation at the calyx from 85.702 per cent to 0.223 per cent, a reduction to approximately one three-hundred-and-eighty-fourth of the original infestation. That is, the check plat showed 384 times more pears wormy at the calyx than was the case with Plat I. The infestation at the side and stem was reduced from 8.198 per cent on the check plat to 3.803 per cent for Plat I, a reduction of only a little over one-half of the original infestation. While the infestation at the calyx was reduced 384 times, the infestation at the side and stem was reduced only 2.4 times.

Plat II, which received the two early sprayings for the first-brood worms, but no late spraying corresponding to the third treatment on Plat I, had 0.747 per cent of the pears wormy at the calyx, indicating a reduction to about one one-hundred-and-fourteenth of the original infestation, while the infestation at the side and stem was not reduced but apparently slightly increased, as this plat showed 9.943 per cent of the fruit wormy at the side and stem as against 8.198 per cent wormy at the side and stem in the unsprayed check plat.

This phenomenon might be thought to indicate that there was some repellent action by the arsenate of lead in the calyx cavity to cause the worms to seek the uncoated surface of the pear. However, this is probably explained by the fact that on the unsprayed block such a large portion of the pears were injured by the first-brood worms and fell off the trees before the appearance of the second-brood worms, that, although the same proportion of worms of this second brood entered the side of the fruit in the check block as in the block receiving the two early sprayings, there were not enough pears left on the trees in the check block to bring the average of the total crop of pears, wormy at the side, up to that of Plat II, where a much larger portion of the year's crop had been kept on the trees by the early sprayings. This same condition holds true for the unsprayed check, Plat IV, in Table XXXV, recording experiments at Suisun in 1910. More than 60 per cent of the total crop of fruit from the check plat dropped from the trees, due almost entirely to the work of the firstbrood worms. On the sprayed blocks only 13 to 22 per cent of the total crop of fruit dropped from the trees. 
In Plat II of Table XXXVI, recording the 1909 experiments at Concord, worms were not so prevalent, the fruit on the unsprayed plat being only 53.05 per cent wormy and only about 31 per cent of the fruit dropping from the trees. (See Table XXXVIII.) This plat shows a much higher percentage (13.869 per cent) of the pears wormy at the side and stem. Also, if we examine Plat V of Table XXXIV, recording the 1910 experiments at Walnut Creek, we find a higher percentage of pears wormy at the side and stem, namely, 11.699 per cent as against 8.198 per cent in the check block. Plat V received no treatment for the first-brood worms, but was sprayed once on July 4 just before the second-brood worms began to enter the fruit. The surface of the fruit was fairly well covered, yet the percentage of fruit wormy at the side and stem was greater than was that of the unsprayed block. In this case it will be seen (Tables XLIV and XLV) that there was more fruit on the trees at picking time in Plat $\mathrm{V}$ than on the trees of the check plat. Also there were correspondingly more windfalls from the trees in the check plat than from the trees in Plat V.

All of the plats receiving the first spraying (soon after falling of petals) show a comparatively light infestation at the calyx, and those receiving the two early sprayings have very few pears wormy at the calyx. (See Plats I, II, III, and VII, Table XXXIV.) Those plats on which this first spraying was omitted have a greater percentage of pears wormy at calyx, although they received one thorough spraying just before the first-brood worms began to enter the fruit, which was some four weeks after the petals had fallen. (See Plats IV and VIII, Table XXXIV.)

TABLE XXXIV. - Degree of infestation and relative infestation at different places of entrance by codling-moth larvæ. Plats I to VIII, inclusive, Walnut Creek, Cal., 1910.

\begin{tabular}{|c|c|c|c|c|c|c|c|c|}
\hline \multirow[b]{2}{*}{ Plat. } & \multirow[b]{2}{*}{$\begin{array}{l}\text { Total } \\
\text { number. } \\
\text { of pears. }\end{array}$} & \multirow[b]{2}{*}{$\begin{array}{c}\text { Total } \\
\text { number } \\
\text { of wormy } \\
\text { pears. }\end{array}$} & \multicolumn{3}{|c|}{ Degree of infestation. } & \multicolumn{3}{|c|}{$\begin{array}{l}\text { Relative infestation at differ- } \\
\text { ent places of entrance. }\end{array}$} \\
\hline & & & $\begin{array}{l}\text { Total per } \\
\text { cent of } \\
\text { wormy } \\
\text { pears. }\end{array}$ & $\begin{array}{l}\text { Total per } \\
\text { cent of } \\
\text { pears } \\
\text { wormy } \\
\text { at calyx. }\end{array}$ & $\begin{array}{l}\text { Total per } \\
\text { cent of } \\
\text { pears } \\
\text { wormy at } \\
\text { side and } \\
\text { stem. }\end{array}$ & $\begin{array}{l}\text { Total } \\
\text { number } \\
\text { of worms } \\
\text { (100 per } \\
\text { cent). }\end{array}$ & $\begin{array}{l}\text { Percent- } \\
\text { age of } \\
\text { worms } \\
\text { entering } \\
\text { at calyx. }\end{array}$ & $\begin{array}{l}\text { Percent- } \\
\text { age of } \\
\text { worms } \\
\text { entering } \\
\text { at side } \\
\text { and stem. }\end{array}$ \\
\hline $\begin{array}{l}\text { Plat I, sprayed A pr. } \\
9, \text { May } 2 \text {, July } 14 . .\end{array}$ & 3,126 & 126 & 4.03 & 0.223 & 3.803 & 126 & 5.56 & 94.44 \\
\hline $\begin{array}{l}\text { Plat II, sprayed Apr. } \\
9 \text { and May } 2 . . . . \\
\text { Plat III spraved }\end{array}$ & 4,415 & 472 & 10.69 & .747 & 9.943 & 472 & 6.79 & 93.21 \\
\hline $\begin{array}{l}\text { A pr. } 9 \text { and July } 4 . . . \\
\text { Plat IV, sprayed May }\end{array}$ & 2,477 & 506 & 20.43 & 5.611 & 14.816 & 506 & 27.47 & 72.53 \\
\hline $\begin{array}{l}2 \text { and July } 4 . \\
\text { Plat V, sprayed July }\end{array}$ & 4,096 & 922 & 22.51 & 11. 621 & 10.888 & 922 & 51.63 & 48.37 \\
\hline 4 Plat YI unsuraved & 2,248 & 1,976 & 87.90 & 76.201 & 11. 699 & 1,976 & 86.18 & 13.82 \\
\hline $\begin{array}{l}\text { check............. } \\
\text { Plat ViI, sprayed }\end{array}$ & 2,427 & 2,279 & 93.90 & 85.702 & 8. 198 & 2,279 & 91.27 & 8.73 \\
\hline $\begin{array}{l}\text { Apr. } 9 \ldots \ldots \ldots \\
\text { Plat VIII, sprayed }\end{array}$ & 2,128 & 693 & 32.57 & 9.020 & 23.550 & 693 & 27.71 & 72.29 \\
\hline May $2 . . . .$. & 2,811 & 857 & 30.49 & 14. 695 & 15.795 & 857 & 48.19 & 51.81 \\
\hline
\end{tabular}


TABLE XXXV.-Degree of infestation and relative infestation at different places of entrance by codling-moth larvæ. Plats I-IV, Suisun, Cal., 1910.

\begin{tabular}{|c|c|c|c|c|c|c|c|c|}
\hline \multirow[b]{2}{*}{ Plat. } & \multirow[b]{2}{*}{$\begin{array}{l}\text { Total } \\
\text { number. } \\
\text { of pears. }\end{array}$} & \multirow[b]{2}{*}{$\begin{array}{c}\text { Total } \\
\text { number } \\
\text { of wormy } \\
\text { pears. }\end{array}$} & \multicolumn{3}{|c|}{ Degree of infestation. } & \multicolumn{3}{|c|}{$\begin{array}{l}\text { Relative infestation at differ- } \\
\text { ent places of entrance. }\end{array}$} \\
\hline & & & $\begin{array}{l}\text { Total per } \\
\text { cent of } \\
\text { wormy } \\
\text { pears. }\end{array}$ & $\begin{array}{l}\text { Total per } \\
\text { cent of } \\
\text { pears } \\
\text { wormy } \\
\text { at calyx. }\end{array}$ & $\begin{array}{l}\text { Total per } \\
\text { cent of } \\
\text { pears } \\
\text { wormy at } \\
\text { side and } \\
\text { stem. }\end{array}$ & $\begin{array}{c}\text { Total } \\
\text { number } \\
\text { of worms } \\
\text { (100 per } \\
\text { cent). }\end{array}$ & $\begin{array}{l}\text { Percent- } \\
\text { age of } \\
\text { worms } \\
\text { entering } \\
\text { at calyx. }\end{array}$ & $\begin{array}{l}\text { Percent-- } \\
\text { age of } \\
\text { worms } \\
\text { entering } \\
\text { at side } \\
\text { and stem. }\end{array}$ \\
\hline $\begin{array}{l}\text { Plat I, sprayed Ipr. } \\
6, \text { May } 4, \text { and June } \\
16 \ldots \ldots\end{array}$ & 7,290 & 423 & 5.80 & 1.783 & 4. 019 & 423 & 30.73 & 69.27 \\
\hline $\begin{array}{l}\text { Plat II, sprayed May } \\
5 \text { and June } 16 . . . .\end{array}$ & 6,538 & 1,865 & 28.52 & 19.270 & 9.250 & 1,865 & 67.56 & 32.44 \\
\hline $\begin{array}{l}\text { Plat III, sprayed } \\
\text { Apr. } 7 \text { and June } 17 \text {. }\end{array}$ & 6,381 & 899 & 14.09 & 6.065 & 8. 024 & 899 & 43.05 & 56.95 \\
\hline $\begin{array}{l}\text { Plat IV, unsprayed } \\
\text { check............... }\end{array}$ & 5,941 & 5,651 & 95.12 & 89.143 & 5.975 & 5,651 & 93.72 & 6.28 \\
\hline
\end{tabular}

TABLE XXXVI.-Degree of infestation and relative infestation at different places of entrance by codling-moth larvæ. Plats I to III, inclusive, Concord, Cal., 1909.

\begin{tabular}{|c|c|c|c|c|c|c|c|c|}
\hline \multirow[b]{2}{*}{ Plat. } & \multirow[b]{2}{*}{$\begin{array}{l}\text { Total } \\
\text { number. } \\
\text { of pears. }\end{array}$} & \multirow[b]{2}{*}{$\begin{array}{l}\text { Total } \\
\text { number } \\
\text { of wormy } \\
\text { pears. }\end{array}$} & \multicolumn{3}{|c|}{ Degree of infestation. } & \multicolumn{3}{|c|}{$\begin{array}{l}\text { Relative infestation at differ- } \\
\text { ent places of entrance. }\end{array}$} \\
\hline & & & $\begin{array}{l}\text { Per cent } \\
\text { of wormy } \\
\text { pears. }\end{array}$ & $\begin{array}{l}\text { Per cent } \\
\text { of pears } \\
\text { wormy } \\
\text { at calyx. }\end{array}$ & $\begin{array}{c}\text { Per cent } \\
\text { of pears } \\
\text { wormy at } \\
\text { side and } \\
\text { stem. }\end{array}$ & $\begin{array}{l}\text { Total } \\
\text { number } \\
\text { of worms } \\
\text { (100 per } \\
\text { cent). }\end{array}$ & $\begin{array}{l}\text { Percent- } \\
\text { age of } \\
\text { worms } \\
\text { entering } \\
\text { at calyx. }\end{array}$ & $\begin{array}{l}\text { Percent- } \\
\text { age of } \\
\text { worms } \\
\text { entering } \\
\text { at side } \\
\text { and stem }\end{array}$ \\
\hline $\begin{array}{l}\text { Plat I, sprayed Apr. } \\
17, \text { May } 10, \text { and } \\
\text { June } 29 . \ldots \ldots \ldots . . . . . . \\
\text { Plat II, unsprayed } \\
\text { check................ } \\
\text { Plat III, sprayed } \\
\text { Apr. } 18 \text { and June } 29 .\end{array}$ & $\begin{array}{l}13,219 \\
14,290 \\
13,943\end{array}$ & $\begin{array}{r}379 \\
7,581 \\
1,731\end{array}$ & $\begin{array}{c}2.86 \\
53.05 \\
12.415\end{array}$ & $\begin{array}{r}0.938 \\
39.181 \\
7.954\end{array}$ & $\begin{array}{r}1.929 \\
13.869 \\
4.461\end{array}$ & $\begin{array}{r}379 \\
7,581 \\
1,731\end{array}$ & $\begin{array}{l}32.72 \\
73.86 \\
63.97\end{array}$ & $\begin{array}{l}67.28 \\
26.14 \\
36.03\end{array}$ \\
\hline
\end{tabular}

For the best results in obtaining fruit free from worms, it is desirable to spray three times, but if only two applications can be put on, the two early treatments give far better results than any other two sprayings.

\section{COMMERCIAL RESULTS FROM SPRAYING.}

Contra Costa County, 1909.

The 15-acre Bartlett pear orchard belonging to Mr. George Whitman and located in the central part of Ygnacio Valley, Contra Costa County (see Plate III), was used for this work in 1909. The trees are large and well cared for, comparing favorably with the average California pear orchard.

The larger part of the orchard was included in Plat I as a demonstration. Four rows across the middle of the orchard were left unsprayed for comparison. Plat III consisted of six rows across the north end of the orchard. 
The first spraying for Plats I and III was just after most of the petals had fallen from the trees, April 17 to 21. Calyx cups on some of the second-crop fruit were closing at this time. For this spraying the nozzles were held close to the fruit clusters in order to fill the calyx cavities as much as possible. Many counts showed from 80 to 85 per cent of all cups to have been filled. The second spraying on Plat I came about three weeks later, May 10 to 12, after the first moths were out and depositing eggs. This spraying was omitted on Plat III. The last spraying was for the second-brood worms and was applied June 28 to 30 on Plats I and III, just after the secondbrood moths began to emerge in numbers.

A gasoline power outfit was used for all sprayings. One man was stationed on a tower platform 8 feet above the tank to spray the tops of the trees while two men sprayed from the ground, supplied with bamboo rods 10 and 12 feet long with large nozzles with wide chambers throwing a mist which spread quickly after leaving the nozzle. A uniform pressure of 150 to 175 pounds was maintained, and arsenate of lead at the rate of 2 pounds to 50 gallons of water was used, requiring an average of $2 \frac{1}{2}$ to 3 gallons of spray per tree for each application.

The total expense of spraying, including the arsenate of lead at $12 \frac{1}{2}$ cents per pound, four men to run the machine and do the spraying at $\$ 1.50$ per day for each man, and two horses at $\$ 1$ each per day, and gasoline and lubricating oil, etc., amounted to $6 \frac{1}{2}$ cents per tree for three applications and $4 \frac{1}{3}$ cents per tree for two applications. The records in Tables XXXVII, XXXVIII, and XXXIX give the comparison of the sound and wormy fruit from 10 trees in each plat for the season. The windfalls were gathered and graded once each week.

TABLE XXXVII.-Sound and wormy fruit from 10 pear trees of Plat I, sprayed three times, in orchard of Mr. George Whitman, Concord, Cal., 1909.

\begin{tabular}{|c|c|c|c|c|c|c|c|c|c|c|}
\hline \multirow{2}{*}{ Tree No. } & \multicolumn{3}{|c|}{$\begin{array}{l}\text { Number of windfallen } \\
\text { pears. }\end{array}$} & \multicolumn{3}{|c|}{$\begin{array}{l}\text { Number of pears from } \\
\text { trees. }\end{array}$} & \multicolumn{3}{|c|}{ Total number. } & \multirow{2}{*}{$\begin{array}{l}\text { Per cent } \\
\text { sound. }\end{array}$} \\
\hline & Total. & Wormy. & Sound. & Total. & Wormy. & Sound. & Total. & Wormy. & Sound. & \\
\hline $\begin{array}{l}1 . . \\
2 \ldots \\
3 . . \\
4 . \\
5 . \\
6 . \\
7 . \\
8 . \\
9 . \\
10 .\end{array}$ & $\begin{array}{r}440 \\
95 \\
73 \\
171 \\
90 \\
368 \\
153 \\
122 \\
658 \\
246\end{array}$ & $\begin{array}{r}23 \\
5 \\
8 \\
14 \\
4 \\
19 \\
11 \\
8 \\
19 \\
15\end{array}$ & $\begin{array}{r}417 \\
90 \\
65 \\
157 \\
86 \\
349 \\
142 \\
114 \\
639 \\
231\end{array}$ & $\begin{array}{r}1,294 \\
1,078 \\
775 \\
1,548 \\
1,025 \\
846 \\
1,164 \\
794 \\
1,298 \\
981\end{array}$ & $\begin{array}{l}39 \\
34 \\
24 \\
43 \\
20 \\
21 \\
22 \\
17 \\
19 \\
14\end{array}$ & $\begin{array}{r}1,255 \\
1,044 \\
751 \\
1,505 \\
1,005 \\
825 \\
1,142 \\
777 \\
1,279 \\
967\end{array}$ & $\begin{array}{r}1,734 \\
1,173 \\
848 \\
1,719 \\
1,115 \\
1,214 \\
1,317 \\
916 \\
1,956 \\
1,227\end{array}$ & $\begin{array}{l}62 \\
39 \\
32 \\
57 \\
24 \\
40 \\
33 \\
25 \\
38 \\
29\end{array}$ & $\begin{array}{r}1,672 \\
1,134 \\
816 \\
1,662 \\
1,091 \\
1,174 \\
1,284 \\
891 \\
1,918 \\
1,198\end{array}$ & $\begin{array}{l}96.42 \\
96.68 \\
96.23 \\
96.68 \\
97.85 \\
96.71 \\
97.50 \\
97.28 \\
98.06 \\
97.64\end{array}$ \\
\hline $\begin{array}{r}\text { Total, trees } \\
1-10 \ldots .\end{array}$ & 2,416 & 126 & 2,290 & 10,803 & 253 & 10,550 & 13,219 & 379 & 12.840 & 97.12 \\
\hline
\end{tabular}




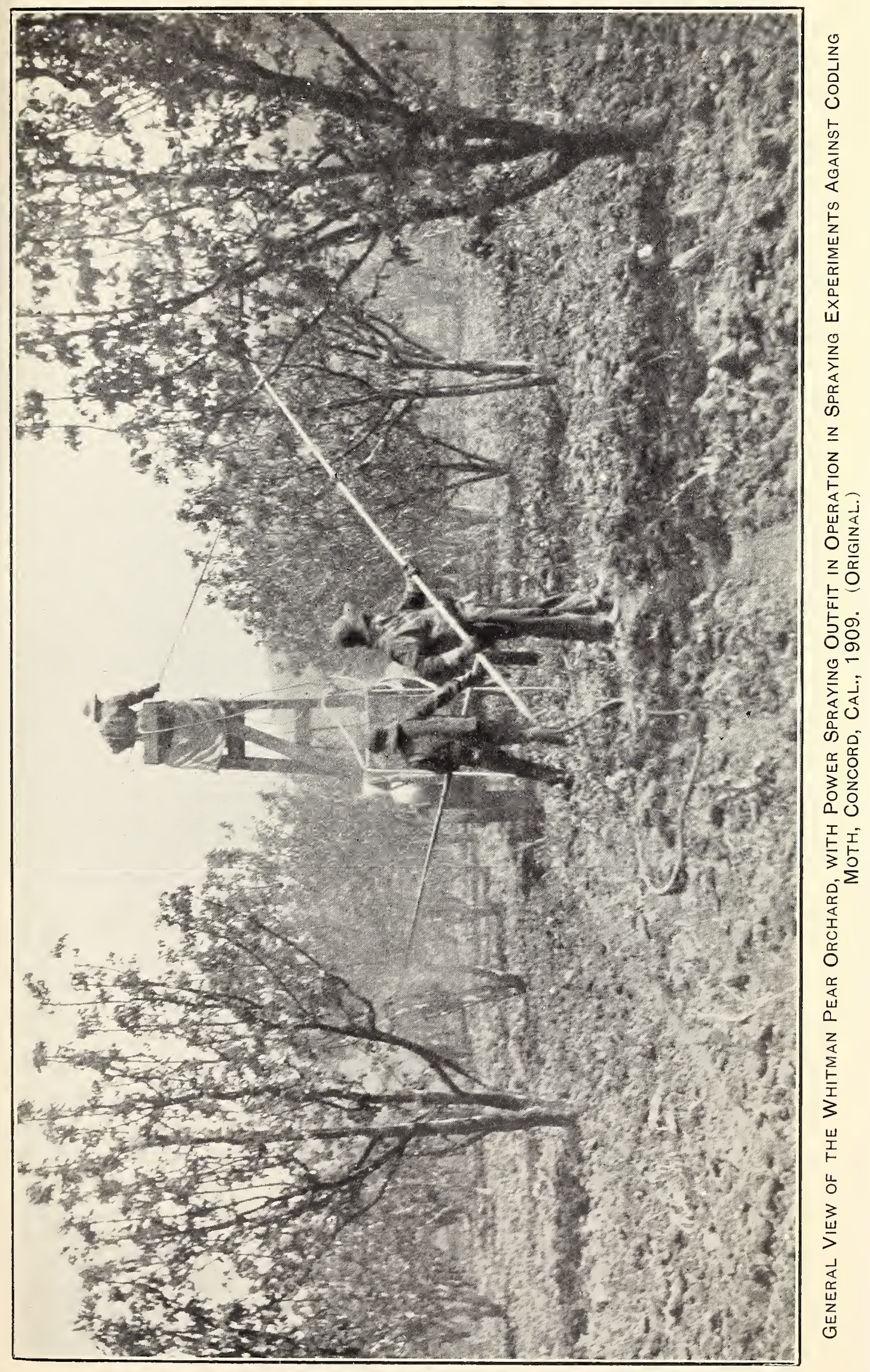



TABLE XXXVIII.-Sound and wormy fruit from 10 pear trees from unsprayed check plat in pear orchard of Mr. George Whitman, Concord, Cal., 1909.

\begin{tabular}{|c|c|c|c|c|c|c|c|c|c|c|}
\hline \multirow{2}{*}{ Tree No. } & \multicolumn{3}{|c|}{$\begin{array}{c}\text { Number of windfallen } \\
\text { pears. }\end{array}$} & \multicolumn{3}{|c|}{$\begin{array}{l}\text { Number of pears from } \\
\text { trees. }\end{array}$} & \multicolumn{3}{|c|}{ Total number. } & \multirow{2}{*}{$\begin{array}{l}\text { Per cent } \\
\text { sound. }\end{array}$} \\
\hline & Total. & Wormy. & Sound. & Total. & Wormy. & Sound. & Total. & Wormy. & Sound. & \\
\hline & $\begin{array}{l}610 \\
619 \\
456 \\
444 \\
430 \\
390 \\
356 \\
351 \\
407 \\
416\end{array}$ & $\begin{array}{l}311 \\
307 \\
248 \\
213 \\
262 \\
230 \\
201 \\
242 \\
242 \\
288\end{array}$ & $\begin{array}{l}299 \\
312 \\
208 \\
231 \\
168 \\
160 \\
155 \\
109 \\
165 \\
128\end{array}$ & $\begin{array}{r}1,358 \\
982 \\
929 \\
764 \\
949 \\
1,315 \\
1,164 \\
678 \\
885 \\
787\end{array}$ & $\begin{array}{l}833 \\
551 \\
425 \\
350 \\
459 \\
560 \\
596 \\
395 \\
460 \\
408\end{array}$ & $\begin{array}{l}525 \\
431 \\
501 \\
414 \\
490 \\
755 \\
568 \\
283 \\
425 \\
379\end{array}$ & $\begin{array}{l}1,968 \\
1,601 \\
1,385 \\
1,208 \\
1,379 \\
1,705 \\
1,520 \\
1,029 \\
1,292 \\
1,203\end{array}$ & $\begin{array}{r}1,144 \\
858 \\
673 \\
563 \\
721 \\
790 \\
797 \\
637 \\
702 \\
696\end{array}$ & $\begin{array}{l}824 \\
743 \\
712 \\
645 \\
658 \\
915 \\
723 \\
392 \\
590 \\
507\end{array}$ & $\begin{array}{l}41.87 \\
46.41 \\
51.40 \\
53.39 \\
47.72 \\
53.67 \\
47.57 \\
38.08 \\
45.67 \\
42.14\end{array}$ \\
\hline $\begin{array}{l}\text { Total, trees } \\
1-10 \ldots .\end{array}$ & 4,479 & $2,5+4$ & 1,935 & 9,811 & 5,037 & 4,774 & 14,290 & 7,581 & 6,709 & 46.95 \\
\hline
\end{tabular}

TABLE XXXIX.-Sound and wormy fruit from 10 pear trees in Plat III, sprayed twice, in orchard of Mr. George Whitman, Concord, Cal., 1909.

\begin{tabular}{|c|c|c|c|c|c|c|c|c|c|c|}
\hline \multirow{2}{*}{ Tree No. } & \multicolumn{3}{|c|}{$\begin{array}{l}\text { Number of windfallen } \\
\text { pears. }\end{array}$} & \multicolumn{3}{|c|}{$\begin{array}{c}\text { Number of pears from } \\
\text { trees. }\end{array}$} & \multicolumn{3}{|c|}{ Total number. } & \multirow{2}{*}{$\begin{array}{l}\text { Per cent } \\
\text { sound. }\end{array}$} \\
\hline & Total. & Wormy. & Sound. & Total. & Wormy. & Sound. & Total. & Wormy. & Sound. & \\
\hline $\begin{array}{c}1 . . \\
2 \ldots \\
3 . \\
4 \ldots \\
5 . \\
6 . \\
7 . \\
8 . \\
9 . \\
10 .\end{array}$ & $\begin{array}{l}420 \\
336 \\
203 \\
418 \\
549 \\
431 \\
281 \\
374 \\
467 \\
669\end{array}$ & $\begin{array}{l}43 \\
62 \\
21 \\
50 \\
62 \\
54 \\
22 \\
35 \\
37 \\
31\end{array}$ & $\begin{array}{l}377 \\
274 \\
182 \\
368 \\
487 \\
377 \\
259 \\
339 \\
430 \\
638\end{array}$ & $\begin{array}{r}897 \\
1,055 \\
1,120 \\
867 \\
889 \\
875 \\
653 \\
1,150 \\
1,171 \\
1,118\end{array}$ & $\begin{array}{r}140 \\
175 \\
95 \\
145 \\
209 \\
130 \\
95 \\
111 \\
10 \tilde{5} \\
109\end{array}$ & $\begin{array}{r}757 \\
880 \\
1,025 \\
722 \\
680 \\
745 \\
558 \\
1,039 \\
1,066 \\
1,009\end{array}$ & $\begin{array}{r}1,317 \\
1,391 \\
1,323 \\
1,285 \\
1,438 \\
1,306 \\
934 \\
1,524 \\
1,638 \\
1,787\end{array}$ & $\begin{array}{l}183 \\
237 \\
116 \\
195 \\
271 \\
184 \\
117 \\
146 \\
142 \\
140\end{array}$ & $\begin{array}{r}1,134 \\
1,154 \\
1,207 \\
1,090 \\
1,167 \\
1,122 \\
817 \\
1,378 \\
1,496 \\
1,647\end{array}$ & $\begin{array}{l}86.10 \\
82.96 \\
91.24 \\
84.82 \\
81.16 \\
85.91 \\
87.47 \\
80.58 \\
91.33 \\
92.17\end{array}$ \\
\hline $\begin{array}{l}\text { Total, trees } \\
1-10 \ldots . .\end{array}$ & 4,148 & 417 & 3,731 & 9,795 & 1,314 & 8,481 & 13,943 & 1,731 & 12,212 & 87.59 \\
\hline
\end{tabular}

The fruit from the unsprayed plat was 53.05 per cent wormy. That of Plat III, sprayed twice, was 12.41 per cent wormy, showing a gain of 40.64 per cent for two sprayings, and Plat I had 2.87 per cent wormy pears with 97.12 per cent sound, realizing an increase of 50.18 per cent sound fruit over the unsprayed trees.

\section{PROFITS.}

The 10 trees in the unsprayed block, Plat II, Table XXXVIII, gave a yield of 4,774 sound pears. Allowing 150 pears per box this would give 31.82 boxes of shipping fruit. The net price this year for pears shipped east was about 80 cents per box. Taking this as the price for all the sound pears shows a total of $\$ 25.45$ returns from the 10 trees not sprayed. Counting all windfalls after July 3 and all the wormy fruit picked from the tree as fit for drying there were 7,939 such pears, or approximately 2,540 pounds, which would make 362 
pounds of dried fruit. ${ }^{a}$ Allowing 7 cents per pound for this, minus $1 \frac{1}{2}$ cents for the cost of drying, gives $\$ 19.95$, the possible returns for the fruit not shipped. This, with the amount received for the fruit shipped, gives a total of $\$ 45.50$ returns for the 10 trees, or $\$ 4.55$ per tree.

Plat III, Table XXXIX, produced 8,481 sound pears, or 63.20 boxes, which at 80 cents per box gives a gross return of $\$ 50.56$ for the fruit shipped. There were 4,159 wormy pears and windfalls for the dry ground, or 1,321 pounds of green fruit, giving 188.70 pounds of dried fruit, which, at the same price as the other, makes $\$ 10.37$. This, added to the $\$ 50.56$ for the fruit shipped east, gives $\$ 60.93$ for the gross returns from the ten trees, or $\$ 6.09$ per tree. Deducting from this $4 \frac{1}{3}$ cents for the cost of spraying, leaves a net return of $\$ 6.04$ per tree, or a net increase of $\$ 1.49$ per tree for the two sprayings over the check block.

Plat I, Table XXXVII, sprayed three times, gave 10,550 sound pears picked from the 10 trees, or 70.33 boxes. At 80 cents per box this gives $\$ 56.26$ returns for the fruit shipped. There were 1,941 windfalls and wormy pears from the trees, or 621 pounds of green fruit, making 88.70 pounds of dried fruit, which at 7 cents per pound (minus $1 \frac{1}{2}$ cents, the cost of drying) leaves $\$ 4.88$ for the dried fruit. Adding this to the returns for the shipped fruit gives $\$ 61.14$ gross returns for the 10 trees, or $\$ 6.114$ per tree. Deducting from this $6 \frac{1}{2}$ cents, the cost of spraying three times, leaves a net return of $\$ 6.04$ per tree, a net increase of $\$ 1.49$ per tree or $\$ 156.45$ per acre orer the unsprayed trees.

These figures show no gain in Plat I over Plat III for the extra spraying, which came May 10 to 11 , but by referring to Tables XXXVII and XXXIX it will be seen that there was an increase of 9.42 per cent of sound fruit for this spraying. Also the total number of pears from the 10 trees in Plat III was greater by 724, or there were 5.17 per cent more pears than from the 10 trees in. Plat I. The difference was even greater between the check block and the demonstration. The check block, Plat II, having 1,071, or 7.42 per cent, more pears than the 10 trees in Plat III.

Contra Costa County, 1910.

An orchard consisting of about 750 Bartlett pear trees belonging to the Mrs. Fanny W. Bancroft Orchard Co. and located some 3 miles from Walnut Creek was used for the experiments in 1910. The orchard was laid off into eight plats of from 75 to 100 trees each and sprayed as follows:

a All figures for these ratios are based on 150 pears to a box of 48 pounds and a ratio of 7 tons of fruit as it is picked up in the field producing 1 ton of dried fruit. 


\begin{tabular}{|c|c|c|c|}
\hline Plat No. & $\begin{array}{c}\text { First } \\
\text { spraying, } \\
\text { Apr. 9. }\end{array}$ & $\begin{array}{c}\text { Second } \\
\text { spraying, } \\
\text { May 2. }\end{array}$ & Third spraying, July 4. \\
\hline $\begin{array}{c}\text { I } \\
\text { II } \\
\text { III } \\
\text { V } \\
\text { VI } \\
\text { VII } \\
\text { VIII }\end{array}$ & $\begin{array}{l}\text { XX.... } \\
\text { XX.... } \\
\text { XX.... } \\
\text { Omit.... } \\
\text { Omit... } \\
\text { Omit.... } \\
\text { XX..... } \\
\text { Omit... }\end{array}$ & $\begin{array}{l}\text { XX.... } \\
\text { XX.... } \\
\text { Omit... } \\
\text { XX.... } \\
\text { Omit.... } \\
\text { Omit.... } \\
\text { Omit... } \\
\text { XX.... }\end{array}$ & $\begin{array}{l}\text { XX (demonstration). } \\
\text { Omit. } \\
\text { XX. } \\
\text { XX. } \\
\text { XX. } \\
\text { Omit (check). } \\
\text { Omit. } \\
\text { Omit. }\end{array}$ \\
\hline
\end{tabular}

The codling moth had been very abundant in this orchard for several years, frequently occurring in such numbers that 90 per cent or more of the fruit was infested. The unsprayed plat this year had 93.90 per cent wormy fruit. The same outfit was used this year as was used in the Whitman orchard in 1909 and the same materials, namely, arsenate of lead, except that half of each plat was sprayed with arsenate of lead at the rate of 6 pounds to each 100 gallons of water and the other half with arsenate of lead at the rate of 4 pounds to each 100 gallons of water at each application. Five of the ten trees selected for records were taken from each half of the blocks and the records kept separately throughout the season. No consistent differences could be found and it is quite evident that 4 pounds of arsenate of lead is as efficient as 6 pounds for each 100 gallons of water. All spraying was done thoroughly and, so far as possible, all the calyx cups on those plats receiving the first application were well filled with spray. The results showing the sound and wormy fruit from the eight plats are given in Tables XL to XINII. The windfalls were gathered and examined once each week.

TABLE XL.-Sound and wormu fruit from 10 trees in Plat I, sprayed three times, pear orchard of the Mrs. Fanny W. Bancroft Orchard Co., near Walnut Creek, Cal., 1910.

\begin{tabular}{|c|c|c|c|c|c|c|c|c|c|c|c|}
\hline \multirow{2}{*}{ Tree No. } & \multicolumn{3}{|c|}{$\begin{array}{c}\text { Number of wind fallen } \\
\text { pears. }\end{array}$} & \multicolumn{3}{|c|}{$\begin{array}{c}\text { Number of pears from } \\
\text { trees. }\end{array}$} & \multicolumn{3}{|c|}{ Total number. } & \multicolumn{2}{|c|}{ Per cent- } \\
\hline & Total. & Wormy. & Sound. & Total. & Wormy. & Sound. & Total. & Wormy. & Sound. & Wormy. & Sound. \\
\hline $\begin{array}{c}1 \ldots \ldots \\
2 \ldots \ldots \\
3 \ldots \ldots \\
4 \ldots \ldots \\
5 \ldots \ldots \\
6 \ldots \ldots \\
7 \ldots \ldots \\
8 \ldots \ldots \\
9 \ldots \ldots \\
10 \ldots \ldots \\
\ldots \ldots \\
\ldots\end{array}$ & $\begin{array}{r}28 \\
8 \\
28 \\
19 \\
15 \\
18 \\
34 \\
69 \\
30 \\
12\end{array}$ & $\begin{array}{l}1 \\
3 \\
1 \\
2 \\
3 \\
2 \\
8 \\
8 \\
6 \\
2 \\
1\end{array}$ & $\begin{array}{r}27 \\
5 \\
27 \\
17 \\
12 \\
16 \\
26 \\
63 \\
28 \\
11\end{array}$ & $\begin{array}{l}411 \\
143 \\
364 \\
218 \\
138 \\
232 \\
459 \\
301 \\
381 \\
218\end{array}$ & $\begin{array}{r}9 \\
7 \\
5 \\
4 \\
6 \\
7 \\
21 \\
19 \\
15 \\
4\end{array}$ & $\begin{array}{l}402 \\
136 \\
359 \\
214 \\
132 \\
225 \\
438 \\
282 \\
366 \\
214\end{array}$ & $\begin{array}{l}439 \\
151 \\
392 \\
237 \\
153 \\
250 \\
493 \\
370 \\
411 \\
230\end{array}$ & $\begin{array}{r}10 \\
10 \\
6 \\
6 \\
9 \\
9 \\
29 \\
25 \\
17 \\
5\end{array}$ & $\begin{array}{l}429 \\
141 \\
386 \\
231 \\
144 \\
241 \\
464 \\
345 \\
394 \\
225\end{array}$ & $\begin{array}{l}2.28 \\
6.62 \\
1.53 \\
2.53 \\
5.88 \\
3.60 \\
5.88 \\
6.76 \\
4.14 \\
2.17\end{array}$ & $\begin{array}{l}97.72 \\
93.38 \\
98.47 \\
97.47 \\
94.12 \\
96.40 \\
94.12 \\
93.24 \\
9.5 .86 \\
97.83\end{array}$ \\
\hline $\begin{array}{l}\text { Total, trees } \\
1-10 \ldots \ldots\end{array}$ & $2 f 1$ & 29 & 232 & 2,865 & 97 & 2,768 & 3,126 & 126 & 3,000 & 4. 03 & 95.97 \\
\hline
\end{tabular}


TABLE XLI. Sound and wormy fruit from 10 trees of Plat II, sprayed Apr. 9 and May 2, being only first two applications as given Plat I, pear orchard of the Mrs. Fanny $W^{-}$. Bancroft Orchard Co., 1910.

\begin{tabular}{|c|c|c|c|c|c|c|c|c|c|c|c|}
\hline \multirow{2}{*}{ Tree Ňo. } & \multicolumn{3}{|c|}{$\begin{array}{c}\text { Number of windfallen } \\
\text { pears. }\end{array}$} & \multicolumn{3}{|c|}{$\begin{array}{c}\text { Number of pears fromı } \\
\text { trees. }\end{array}$} & \multicolumn{3}{|c|}{ Total number. } & \multicolumn{2}{|c|}{ Per cent- } \\
\hline & Total. & Wormy. & Sound. & Total. & Wormy. & Sound. & Total. & Wormy. & Sound. & Wormy. & Sound. \\
\hline $\begin{array}{c}1 \ldots \ldots \\
2 \ldots \\
3 \ldots \\
4 \ldots \\
5 \ldots \\
6 \ldots \\
7 \ldots \\
8 \ldots \\
9 \ldots \\
10 . \ldots \\
10 . \\
\end{array}$ & $\begin{array}{l}13 \\
17 \\
19 \\
12 \\
32 \\
18 \\
29 \\
31 \\
20 \\
21\end{array}$ & $\begin{array}{l}2 \\
2 \\
2 \\
2 \\
6 \\
2 \\
6 \\
4 \\
2 \\
2\end{array}$ & $\begin{array}{l}11 \\
15 \\
17 \\
10 \\
26 \\
16 \\
23 \\
27 \\
18 \\
19\end{array}$ & $\begin{array}{l}429 \\
425 \\
323 \\
395 \\
316 \\
363 \\
509 \\
492 \\
458 \\
493\end{array}$ & $\begin{array}{l}32 \\
56 \\
21 \\
37 \\
41 \\
43 \\
41 \\
60 \\
75 \\
36\end{array}$ & $\begin{array}{l}397 \\
369 \\
302 \\
358 \\
275 \\
320 \\
468 \\
432 \\
383 \\
457\end{array}$ & $\begin{array}{l}442 \\
442 \\
342 \\
407 \\
348 \\
381 \\
538 \\
523 \\
478 \\
514\end{array}$ & $\begin{array}{l}34 \\
58 \\
23 \\
39 \\
47 \\
45 \\
47 \\
64 \\
77 \\
38\end{array}$ & $\begin{array}{l}408 \\
384 \\
319 \\
368 \\
301 \\
336 \\
491 \\
459 \\
401 \\
476\end{array}$ & $\begin{array}{r}7.69 \\
13.12 \\
6.73 \\
9.58 \\
13.51 \\
11.81 \\
8.74 \\
12.24 \\
16.11 \\
7.39\end{array}$ & $\begin{array}{l}92.31 \\
86.88 \\
93.27 \\
90.42 \\
86.49 \\
88.19 \\
91.26 \\
87.76 \\
83.89 \\
92.61\end{array}$ \\
\hline $\begin{array}{l}\text { Total, trees } \\
1-10 \ldots .\end{array}$ & 212 & 30 & 182 & 4,203 & 442 & 3,761 & 4,415 & 472 & 3,943 & 10.69 & 89.31 \\
\hline
\end{tabular}

"TABLE XLII.--Sound and wormy fruit from 10 trees in Plat III, sprayed Apr. 9 and July 4, being first and third applications as given Plat I, pear orchard of the Mrs. Fanny W. Bancroft Orchard Co., 1910.

\begin{tabular}{|c|c|c|c|c|c|c|c|c|c|c|c|}
\hline \multirow{2}{*}{ Tree No. } & \multicolumn{3}{|c|}{$\begin{array}{c}\text { Number of windfallen } \\
\text { pears. }\end{array}$} & \multicolumn{3}{|c|}{$\begin{array}{c}\text { Number of pears from } \\
\text { trees. }\end{array}$} & \multicolumn{3}{|c|}{ Total number. } & \multicolumn{2}{|c|}{ Per cent- } \\
\hline & Total. & Wormy. & Sound. & Total. & Wormy. & Sound. & Total. & Wormy. & Sound. & Wormy. & Sound. \\
\hline 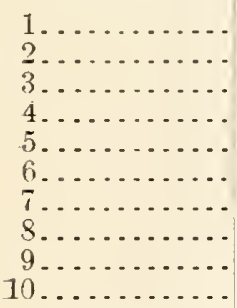 & $\begin{array}{l}78 \\
19 \\
27 \\
24 \\
45 \\
25 \\
55 \\
18 \\
26 \\
40\end{array}$ & $\begin{array}{r}14 \\
11 \\
10 \\
9 \\
17 \\
9 \\
19 \\
9 \\
11 \\
22\end{array}$ & $\begin{array}{r}64 \\
8 \\
17 \\
15 \\
28 \\
16 \\
36 \\
9 \\
1.5 \\
18\end{array}$ & $\begin{array}{l}231 \\
212 \\
132 \\
134 \\
289 \\
131 \\
438 \\
105 \\
119 \\
329\end{array}$ & $\begin{array}{l}45 \\
38 \\
23 \\
24 \\
66 \\
20 \\
53 \\
15 \\
16 \\
75\end{array}$ & $\begin{array}{r}186 \\
174 \\
109 \\
110 \\
223 \\
111 \\
385 \\
90 \\
103 \\
254\end{array}$ & $\begin{array}{l}309 \\
231 \\
159 \\
158 \\
334 \\
156 \\
493 \\
123 \\
145 \\
369\end{array}$ & $\begin{array}{l}59 \\
49 \\
33 \\
33 \\
83 \\
29 \\
72 \\
24 \\
27 \\
97\end{array}$ & $\begin{array}{r}250 \\
182 \\
126 \\
125 \\
251 \\
127 \\
421 \\
99 \\
118 \\
272\end{array}$ & $\begin{array}{l}19.09 \\
21.21 \\
20.75 \\
20.85 \\
24.85 \\
18.59 \\
14.60 \\
19.51 \\
18.62 \\
26.29\end{array}$ & $\begin{array}{l}80.91 \\
78.79 \\
79.25 \\
79.11 \\
75.15 \\
81.41 \\
85.40 \\
80.49 \\
81.38 \\
73.71\end{array}$ \\
\hline $\begin{array}{r}\text { Total, trees } \\
1-10 \ldots .\end{array}$ & 357 & 131 & 226 & 2,120 & 375 & 1,745 & 2,477 & 506 & 1,971 & 20.43 & 79.57 \\
\hline
\end{tabular}

TABLE XLIII.-Sound and wormy fruit from 10 trees in Plat IV, sprayed May 2 and July 4 , being second and third applications as given Plat I, pear orchard of the Mrs. Fanny W. Bancroft Orchard Co., 1910.

\begin{tabular}{|c|c|c|c|c|c|c|c|c|c|c|c|}
\hline \multirow{2}{*}{ Tree No. } & \multicolumn{3}{|c|}{$\begin{array}{l}\text { Number of windfallen } \\
\text { pears. }\end{array}$} & \multicolumn{3}{|c|}{$\begin{array}{c}\text { Number of pears from } \\
\text { trees. }\end{array}$} & \multicolumn{3}{|c|}{ Total number. } & \multicolumn{2}{|c|}{ Per cent- } \\
\hline & Total. & Wormy. & Sound. & Total. & Wormy. & Sound. & Total. & Wormy. & Sound. & Wormy. & Sound. \\
\hline $\begin{array}{l}1 \ldots \\
2 \ldots \\
3 \ldots \\
4 \ldots \\
5 \ldots \\
6 \ldots \\
5 \ldots \\
8 . \\
6 \ldots \\
10 .\end{array}$ & $\begin{array}{l}88 \\
81 \\
76 \\
53 \\
22 \\
43 \\
53 \\
20 \\
16 \\
21\end{array}$ & $\begin{array}{l}21 \\
39 \\
49 \\
35 \\
15 \\
24 \\
26 \\
14 \\
11 \\
13\end{array}$ & $\begin{array}{r}67 \\
42 \\
27 \\
18 \\
7 \\
19 \\
27 \\
6 \\
5 \\
8\end{array}$ & $\begin{array}{l}411 \\
472 \\
388 \\
507 \\
114 \\
547 \\
519 \\
220 \\
286 \\
159\end{array}$ & $\begin{array}{l}80 \\
78 \\
87 \\
89 \\
21 \\
88 \\
82 \\
52 \\
66 \\
32\end{array}$ & \begin{tabular}{r|}
331 \\
394 \\
301 \\
418 \\
93 \\
459 \\
437 \\
168 \\
220 \\
127
\end{tabular} & $\begin{array}{l}499 \\
553 \\
464 \\
560 \\
136 \\
590 \\
572 \\
240 \\
302 \\
180\end{array}$ & $\begin{array}{r}101 \\
117 \\
136 \\
124 \\
36 \\
112 \\
108 \\
66 \\
77 \\
45\end{array}$ & $\begin{array}{l}398 \\
436 \\
328 \\
436 \\
100 \\
478 \\
464 \\
174 \\
225 \\
135\end{array}$ & $\begin{array}{r}21.44 \\
21.16 \\
29.31 \\
22.14 \\
26.47 \\
18.98 \\
18.89 \\
27.50 \\
25.50 \\
25.00\end{array}$ & $\begin{array}{l}79.56 \\
78.84 \\
70.69 \\
77.86 \\
73.53 \\
81.02 \\
81.12 \\
72.50 \\
74.50 \\
75.00\end{array}$ \\
\hline $\begin{array}{l}\text { Total, trees } \\
1-10 \ldots . . .\end{array}$ & 473 & 247 & 226 & 3,623 & 675 & 2,948 & 4,096 & 922 & 3,174 & 22.51 & 77.49 \\
\hline
\end{tabular}


TABLE XLIV.-Sound and wormy fruit from 10 trees of Plat V, sprayed July 4, being third application as given Plat I (treatments for first-brood worms omitted), pear orchard of the Mrs. Fanny W. Bancroft Orchard Co., 1910.

\begin{tabular}{|c|c|c|c|c|c|c|c|c|c|c|c|}
\hline \multirow{2}{*}{ Tree No. } & \multicolumn{3}{|c|}{$\begin{array}{c}\text { Number of windfallen } \\
\text { pears. }\end{array}$} & \multicolumn{3}{|c|}{$\begin{array}{c}\text { Number of pears from } \\
\text { trees. }\end{array}$} & \multicolumn{3}{|c|}{ Total number. } & \multicolumn{2}{|c|}{ Per cent- } \\
\hline & Total. & Wormy & Sound. & Total. & Wormy. & Sound. & Total. & Wormy. & Sound. & Wormy. & Sound. \\
\hline 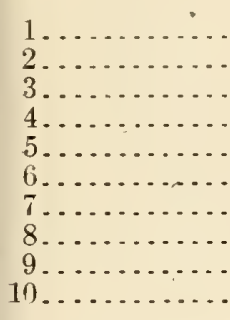 & $\begin{array}{r}87 \\
139 \\
85 \\
91 \\
128 \\
112 \\
229 \\
83 \\
90 \\
46\end{array}$ & $\begin{array}{r}78 \\
132 \\
80 \\
84 \\
116 \\
108 \\
218 \\
82 \\
83 \\
41\end{array}$ & $\begin{array}{r}9 \\
7 \\
5 \\
7 \\
12 \\
4 \\
11 \\
1 \\
7 \\
5\end{array}$ & $\begin{array}{r}109 \\
134 \\
79 \\
66 \\
132 \\
102 \\
263 \\
97 \\
104 \\
72\end{array}$ & $\begin{array}{r}89 \\
112 \\
59 \\
56 \\
116 \\
94 \\
198 \\
83 \\
89 \\
58\end{array}$ & $\begin{array}{r}20 \\
22 \\
20 \\
10 \\
16 \\
8 \\
65 \\
14 \\
15 \\
14\end{array}$ & $\begin{array}{l}196 \\
273 \\
164 \\
157 \\
260 \\
214 \\
492 \\
180 \\
194 \\
118\end{array}$ & $\begin{array}{r}167 \\
244 \\
139 \\
140 \\
232 \\
202 \\
416 \\
165 \\
172 \\
99\end{array}$ & $\begin{array}{l}29 \\
29 \\
2.5 \\
17 \\
28 \\
12 \\
76 \\
15 \\
22 \\
19\end{array}$ & $\begin{array}{l}85.20 \\
89.38 \\
84.76 \\
89.17 \\
89.23 \\
94.40 \\
84.55 \\
91.67 \\
88.66 \\
83.89\end{array}$ & $\begin{array}{r}14.80 \\
10.62 \\
15.24 \\
10.83 \\
10.77 \\
5.60 \\
15.45 \\
8.33 \\
11.31 \\
16.11\end{array}$ \\
\hline $\begin{array}{r}\text { Total, trees } \\
1-10 \ldots .\end{array}$ & 1,090 & 1,022 & 68 & 1,158 & 954 & 204 & 2,248 & 1,976 & 272 & 87.90 & 12. 10 \\
\hline
\end{tabular}

TABLE XLV.-Sound and wormy fruit from 10 trees in Plat VI, unsprayed check, pear orchard of the Mrs. Fanny W. Bancroft Orchard Co., 1910.

\begin{tabular}{|c|c|c|c|c|c|c|c|c|c|c|c|}
\hline \multirow{2}{*}{ Tree No. } & \multicolumn{3}{|c|}{$\begin{array}{c}\text { Number of windfallen } \\
\text { pears. }\end{array}$} & \multicolumn{3}{|c|}{$\begin{array}{c}\text { Number of pears from } \\
\text { trees. }\end{array}$} & \multicolumn{3}{|c|}{ Total number. } & \multicolumn{2}{|c|}{ Per cent- } \\
\hline & Total. & Wormy. & Sound. & Total. & Wormy. & Sound. & Total. & Wormy & Sound. & Wormy & Sound. \\
\hline $\begin{array}{c}1 \ldots \\
2 \ldots \\
3 . . \\
4 \ldots \\
5 \ldots \\
6 . \\
7 . \\
8 . \\
9 . \\
10 . \\
\end{array}$ & $\begin{array}{r}208 \\
122 \\
194 \\
148 \\
100 \\
148 \\
63 \\
114 \\
127 \\
127\end{array}$ & $\begin{array}{r}192 \\
119 \\
181 \\
139 \\
95 \\
119 \\
58 \\
105 \\
119 \\
118\end{array}$ & $\begin{array}{r}16 \\
3 \\
13 \\
9 \\
5 \\
29 \\
5 \\
9 \\
8 \\
9\end{array}$ & $\begin{array}{r}158 \\
95 \\
136 \\
126 \\
84 \\
54 \\
103 \\
103 \\
139 \\
78\end{array}$ & $\begin{array}{r}153 \\
91 \\
134 \\
119 \\
84 \\
52 \\
95 \\
97 \\
134 \\
75\end{array}$ & $\begin{array}{l}5 \\
4 \\
2 \\
7 \\
0 \\
2 \\
8 \\
6 \\
5 \\
3\end{array}$ & $\begin{array}{l}366 \\
217 \\
330 \\
274 \\
184 \\
202 \\
166 \\
217 \\
266 \\
205\end{array}$ & $\begin{array}{l}345 \\
210 \\
315 \\
258 \\
179 \\
171 \\
153 \\
202 \\
253 \\
193\end{array}$ & $\begin{array}{r}21 \\
7 \\
15 \\
16 \\
5 \\
31 \\
13 \\
15 \\
13 \\
12\end{array}$ & $\begin{array}{l}94.26 \\
96.77 \\
95.45 \\
94.16 \\
97.82 \\
84.65 \\
92.17 \\
93.09 \\
95.11 \\
94.14\end{array}$ & $\begin{array}{r}5.74 \\
3.23 \\
4.55 \\
5.84 \\
2.18 \\
15.35 \\
7.83 \\
6.91 \\
4.89 \\
5.86\end{array}$ \\
\hline $\begin{array}{r}\text { Total, trees } \\
1-10 \ldots . .\end{array}$ & 1,351 & 1,245 & 106 & 1,076 & 1,034 & 42 & 2,427 & 2,279 & 148 & 93.90 & 6.10 \\
\hline
\end{tabular}

TABLE XLVI.-Sound and wormy fruit from 10 trees of Plat VII, sprayed A pr. 9, being first application as given Plat I, pear orchard of the Mrs. Fanny W. Bancroft Orchard Co., 1910.

\begin{tabular}{|c|c|c|c|c|c|c|c|c|c|c|c|}
\hline \multirow{2}{*}{ Tree No. } & \multicolumn{3}{|c|}{$\begin{array}{c}\text { Number of windfallen } \\
\text { pears. }\end{array}$} & \multicolumn{3}{|c|}{$\begin{array}{c}\text { Number of pears from } \\
\text { trees. }\end{array}$} & \multicolumn{3}{|c|}{ Total number. } & \multicolumn{2}{|c|}{ Per cent- } \\
\hline & Total. & Wormy. & Sound. & Total. & Wormy. & Sound. & Total. & Wormy. & Sound. & Wormy. & Sound. \\
\hline $\begin{array}{c}1 \ldots \\
2 \ldots \\
3 \ldots \\
4 \ldots \\
5 \ldots \\
6 \ldots \\
7 \ldots \\
8 . \\
9 \ldots \\
10 .\end{array}$ & $\begin{array}{l}22 \\
14 \\
19 \\
45 \\
19 \\
21 \\
88 \\
34 \\
12 \\
18\end{array}$ & $\begin{array}{r}15 \\
6 \\
10 \\
21 \\
7 \\
9 \\
27 \\
20 \\
6 \\
5\end{array}$ & $\begin{array}{r}7 \\
8 \\
9 \\
24 \\
12 \\
12 \\
61 \\
14 \\
6 \\
13\end{array}$ & $\begin{array}{r}75 \\
97 \\
200 \\
191 \\
182 \\
328 \\
364 \\
166 \\
121 \\
112\end{array}$ & $\begin{array}{r}26 \\
32 \\
88 \\
54 \\
52 \\
116 \\
75 \\
42 \\
45 \\
37\end{array}$ & $\begin{array}{r}49 \\
65 \\
112 \\
137 \\
130 \\
212 \\
289 \\
124 \\
76 \\
75\end{array}$ & $\begin{array}{r}97 \\
111 \\
219 \\
236 \\
201 \\
349 \\
452 \\
200 \\
133 \\
130\end{array}$ & $\begin{array}{r}41 \\
35 \\
98 \\
75 \\
59 \\
125 \\
102 \\
62 \\
51 \\
42\end{array}$ & $\begin{array}{r}56 \\
73 \\
121 \\
161 \\
142 \\
224 \\
350 \\
138 \\
82 \\
88\end{array}$ & $\begin{array}{l}42.27 \\
34.23 \\
44.75 \\
31.78 \\
29.35 \\
35.82 \\
22.57 \\
31.00 \\
38.35 \\
32.31\end{array}$ & $\begin{array}{l}57.73 \\
65.77 \\
55.25 \\
68.22 \\
70.65 \\
64.18 \\
77.43 \\
69.00 \\
61.65 \\
67.69\end{array}$ \\
\hline $\begin{array}{l}\text { 'Total, trees } \\
1-10 . . .\end{array}$ & 292 & 126 & 166 & 1,836 & 567 & 1.269 & 2,128 & 693 & 1.435 & 32.57 & 67.43 \\
\hline
\end{tabular}


TABLE XLVII.-Sound and wormy fruit from 10 trees of Plat VIII, sprayed May 2, being second application as given Plat I, pear orchard of the Mrs. Fanny W. Bancroft Orchard Co., 1910.

\begin{tabular}{|c|c|c|c|c|c|c|c|c|c|c|c|}
\hline \multirow{2}{*}{ Tree No. } & \multicolumn{3}{|c|}{$\begin{array}{l}\text { Number of windfallen } \\
\text { pears. }\end{array}$} & \multicolumn{3}{|c|}{$\begin{array}{c}\text { Number of pears from } \\
\text { trees. }\end{array}$} & \multicolumn{3}{|c|}{ Total number. } & \multicolumn{2}{|c|}{ Per cent- } \\
\hline & Total. & Wormy. & Sound. & Total. & Wormy. & Sound. & Total. & Worms. & Sound. & Wormy. & Sound. \\
\hline $\begin{array}{c}1 \ldots \\
2 \ldots \\
3 \ldots \\
4 \ldots \\
5 \ldots \\
6 \ldots \\
7 \ldots \\
\vdots \ldots \\
10 \ldots \\
10 \ldots\end{array}$ & $\begin{array}{r}6 \\
53 \\
33 \\
44 \\
54 \\
140 \\
33 \\
36 \\
70 \\
4.5\end{array}$ & $\begin{array}{l}1 \\
31 \\
10 \\
29 \\
21 \\
\$ 2 \\
20 \\
19 \\
29 \\
19\end{array}$ & $\begin{array}{r}5 \\
22 \\
23 \\
15 \\
33 \\
58 \\
13 \\
17 \\
42 \\
26\end{array}$ & $\begin{array}{r}61 \\
119 \\
203 \\
324 \\
100 \\
624 \\
165 \\
158 \\
302 \\
208\end{array}$ & $\begin{array}{r}19 \\
70 \\
42 \\
116 \\
29 \\
119 \\
53 \\
39 \\
64 \\
46\end{array}$ & $\begin{array}{r}12 \\
79 \\
161 \\
205 \\
71 \\
505 \\
115 \\
119 \\
238 \\
162\end{array}$ & $\begin{array}{r}67 \\
202 \\
236 \\
368 \\
154 \\
764 \\
201 \\
194 \\
372 \\
253\end{array}$ & $\begin{array}{r}20 \\
101 \\
52 \\
145 \\
50 \\
201 \\
73 \\
58 \\
92 \\
65\end{array}$ & $\begin{array}{r}47 \\
101 \\
1,84 \\
223 \\
104 \\
563 \\
128 \\
136 \\
280 \\
188\end{array}$ & $\begin{array}{l}29.84 \\
50.00 \\
22.03 \\
39.40 \\
32.47 \\
26.31 \\
36.32 \\
29.90 \\
24.73 \\
25.69\end{array}$ & $\begin{array}{r}70.13 \\
50.00 \\
77.97 \\
60.00 \\
67.53 \\
73.69 \\
63.65 \\
70.10 \\
75.27 \\
74.31\end{array}$ \\
\hline $\begin{array}{l}\text { Total, trees } \\
1-10 \ldots . .\end{array}$ & 514 & 260 & 254 & 2.297 & 597 & 1,700 & 2. 811 & 857 & 1.954 & 30.49 & 69.51 \\
\hline
\end{tabular}

The fruit from the unsprayed block Plat VI (Table XLV) was 93.90 per cent wormy, while that from the demonstration block, Plat I (Table XL), sprayed three times, was only 4.03 per cent wormy, showing a gain of 89.87 per cent sound fruit for the three sprayings. Plat II (Table XLI), sprayed twice, both times for the first-brood worms, showed 10.69 per cent wormy, representing a gain in sound fruit of 83.21 per cent for two sprayings put on in time to catch the first-brood worms. Plat III (Table XLII), which was also sprayed twice, these being the first and last applications as given Plat I, the accessory treatment for the first brood being omitted, showed 20.43 per cent wormy fruit, showing a gain of 73.47 per cent sound fruit for the two sprayings. This gain, however, is 10.74 per cent less than was the case where both sprayings were put on in time for the first-brood worms. Plat IV (Table XLIII) received the second and third applications as given Plat I, the first spraying being omitted. The results showed 22.51 per cent of the fruit to be wormy, which is a gain of 70.39 per cent over the check plat, but is 11.82 per cent less than the gain on Plat II, where the two applications were put on early. The other plats, which received only one application, ran too high in wormy fruit to be considered at all from a commercial viewpoint. Thus, Plat VII (Table XLVI), which received only the first application, showed 32.57 per cent wormy and 67.43 per cent sound, while Plat VIII (Table XLVII), which received only the second application, had 30.49 per cent wormy and 69.51 per cent sound. Plat V (Table XLIV), which received only the last application, was little better than the check, haring 87.90 per cent of the fruit wormy and only 12.10 per cent sound. 
PROFITS.

From the 10 trees of Plat I, 2,768 pears free from worms, or 18.45 boxes, were picked, which at the average net price of 80 cents per box gives $\$ 14.76$, or $\$ 1.47$ per tree, which represents about $\$ 147.60$ per acre. To this should be added $\$ 5.60$ which represents the value per acre of the windfalls and wormy fruit from the trees of Plat I, giving a total of $\$ 153.20$.

The 10 trees in Plat VI, the unsprayed check, yielded only 42 pears, or 0.28 box free from worms at picking time. This at 80 cents per box gives 22 cents for the 10 trees, or approximately $\$ 2.20$ per acre. There were, after July 15, 1,032 windfalls and wormy pears picked from the trees, which represent a cash value of $\$ 4.52$ for the 10 trees, or $\$ 45.20$ per acre, giving a total return of $\$ 47.40$ per acre for the fruit from the unsprayed portion. Subtracting this from the value of the crop per acre of Plat I gives a difference of about $\$ 100$ in favor of spraying. Substracting from this $\$ 6.50$, the cost of spraying per acre, gives $\$ 93.50$ net gain per acre due to spraying.

\section{Experiments in Solano County, 1910.}

A large pear orchard belonging to Mr. G. W. Langdon and located near the upper end of Suisun Valley at Suisun, Cal., consists of very old and large trees, and in recent years a very small portion of the fruit has been merchantable in the green state, due to the high infestation by the codling moth. The larger part of the orchard was sprayed three times. Three other blocks of about 70 trees each were used to test the relative value of the first and third applications and the second and third applications with the plat receiving the three applications and one of the plats was left unsprayed for check and comparison. The results showing sound and wormy fruit from each plat are given in Tables XLVIII to LI.

TABLE XIVIII.-Sound and wormy fruit from 10 trees of Plat I, sprayed three times, pear orchard of Mr. G. W. Langdon, Suisun, Cal., 1910.

\begin{tabular}{|c|c|c|c|c|c|c|c|c|c|c|c|}
\hline \multirow{2}{*}{ Tree No. } & \multicolumn{3}{|c|}{$\begin{array}{c}\text { Number of windfallen } \\
\text { pears. }\end{array}$} & \multicolumn{3}{|c|}{$\begin{array}{c}\text { Number of pears from } \\
\text { trees. }\end{array}$} & \multicolumn{3}{|c|}{ Total number. } & \multicolumn{2}{|c|}{ Per cent- } \\
\hline & Total. & Wormy. & Sound. & Total. & Wormy. & Sound. & Total. & Wormy. & Sound. & Wormy. & Sound. \\
\hline $\begin{array}{l}1 \ldots \\
2 \ldots \\
3 \ldots \\
4 \ldots \\
5 \ldots \\
6 \ldots \\
7 \ldots \\
8 \ldots \\
9 \ldots \\
10 \ldots\end{array}$ & $\begin{array}{r}143 \\
97 \\
77 \\
37 \\
110 \\
101 \\
184 \\
103 \\
59 \\
100\end{array}$ & $\begin{array}{r}19 \\
8 \\
6 \\
6 \\
14 \\
12 \\
22 \\
30 \\
13 \\
29\end{array}$ & $\begin{array}{r}124 \\
89 \\
71 \\
31 \\
96 \\
89 \\
162 \\
73 \\
46 \\
71\end{array}$ & $\begin{array}{r}962 \\
599 \\
685 \\
422 \\
666 \\
553 \\
1,094 \\
425 \\
221 \\
652\end{array}$ & $\begin{array}{r}36 \\
15 \\
11 \\
16 \\
12 \\
9 \\
37 \\
39 \\
30 \\
59\end{array}$ & $\begin{array}{r}926 \\
584 \\
674 \\
406 \\
654 \\
544 \\
1,057 \\
386 \\
191 \\
593\end{array}$ & $\begin{array}{r}1,105 \\
696 \\
762 \\
459 \\
776 \\
654 \\
1,278 \\
528 \\
280 \\
752\end{array}$ & $\begin{array}{l}55 \\
23 \\
17 \\
22 \\
26 \\
21 \\
59 \\
69 \\
43 \\
88\end{array}$ & $\begin{array}{r}1,050 \\
673 \\
745 \\
437 \\
750 \\
633 \\
1,219 \\
459 \\
237 \\
664\end{array}$ & $\begin{array}{r}4.98 \\
3.30 \\
2.23 \\
4.79 \\
3.35 \\
3.21 \\
4.62 \\
13.07 \\
15.36 \\
11.70\end{array}$ & $\begin{array}{l}95.02 \\
96.70 \\
97.77 \\
95.21 \\
96.65 \\
96.79 \\
95.38 \\
86.93 \\
84.64 \\
88.30\end{array}$ \\
\hline $\begin{array}{l}\text { Total, trees } \\
1-10 . . .\end{array}$ & 1,011 & 159 & 852 & 6,279 & 264 & 6,015 & 7.290 & 423 & 6,867 & 5.80 & 94.20 \\
\hline
\end{tabular}


TABLE XLIX.-Sound and wormy fruit from 10 trees of Plat II, sprayed May 5 and June 16, being second and third applications as given Plat $I$, pear orchard of $\mathbf{M r}$. G. W. Langdon, Suisun, Cal., 1910.

\begin{tabular}{|c|c|c|c|c|c|c|c|c|c|c|c|}
\hline \multirow{2}{*}{ Tree No. } & \multicolumn{3}{|c|}{$\begin{array}{l}\text { Number of windfallen } \\
\text { pears. }\end{array}$} & \multicolumn{3}{|c|}{$\begin{array}{l}\text { Number of pears from } \\
\text { trees. }\end{array}$} & \multicolumn{3}{|c|}{ Total number. } & \multicolumn{2}{|c|}{ Per cent- } \\
\hline & Total. & Wormy. & Sound. & Total. & Wormy. & Sound. & Total. & Wormy. & Sound. & Wormy. & Sound. \\
\hline & $\begin{array}{r}81 \\
154 \\
128 \\
87 \\
117 \\
283 \\
123 \\
205 \\
51 \\
208\end{array}$ & $\begin{array}{r}57 \\
95 \\
72 \\
51 \\
77 \\
149 \\
74 \\
114 \\
34 \\
103\end{array}$ & $\begin{array}{r}27 \\
59 \\
56 \\
36 \\
40 \\
134 \\
49 \\
91 \\
17 \\
105\end{array}$ & $\begin{array}{l}355 \\
508 \\
665 \\
264 \\
482 \\
632 \\
428 \\
648 \\
248 \\
868\end{array}$ & $\begin{array}{r}56 \\
123 \\
130 \\
52 \\
107 \\
149 \\
76 \\
140 \\
67 \\
139\end{array}$ & $\begin{array}{l}299 \\
385 \\
535 \\
212 \\
375 \\
483 \\
352 \\
508 \\
181 \\
729\end{array}$ & $\begin{array}{r}439 \\
662 \\
793 \\
351 \\
599 \\
915 \\
551 \\
853 \\
299 \\
1,076\end{array}$ & $\begin{array}{l}113 \\
218 \\
202 \\
103 \\
184 \\
298 \\
150 \\
254 \\
101 \\
242\end{array}$ & $\begin{array}{l}326 \\
444 \\
591 \\
248 \\
415 \\
617 \\
401 \\
599 \\
198 \\
834\end{array}$ & $\begin{array}{l}25.74 \\
32.93 \\
25.47 \\
29.34 \\
30.72 \\
32.57 \\
27.22 \\
29.78 \\
33.80 \\
22.49\end{array}$ & $\begin{array}{l}74.26 \\
67.07 \\
74.53 \\
77.66 \\
69.28 \\
67.43 \\
72.78 \\
70.22 \\
66.20 \\
77.51\end{array}$ \\
\hline $\begin{array}{r}\text { Total, trees } \\
1-10 \ldots \ldots\end{array}$ & 1,440 & 826 & 614 & $j, 098$ & 1,039 & $4.05 S$ & 6,538 & 1,865 & 4,673 & 28.52 & 71.48 \\
\hline
\end{tabular}

TABLE L.-Sound and wormy fruit from 10 trees of Plat III, sprayed April $\gamma$ and June 1\%, being first and third applications as given Plat I, pear orchard of Mr. G. W. Langdon, Suisun, Cal., 1910.

\begin{tabular}{|c|c|c|c|c|c|c|c|c|c|c|c|}
\hline \multirow{2}{*}{ Tree No. } & \multicolumn{3}{|c|}{$\begin{array}{c}\text { Number of windfallen } \\
\text { pears. }\end{array}$} & \multicolumn{3}{|c|}{$\begin{array}{c}\text { Number of pears frōm } \\
\text { trees. }\end{array}$} & \multicolumn{3}{|c|}{ Total number. } & \multicolumn{2}{|c|}{ Per cent- } \\
\hline & Total. & Worms. & Sound. & Total. & Worms. & Sound. & Total. & Worms. & Sound. & Wormy. & Sound. \\
\hline $\begin{array}{l}1 \ldots \\
2 \ldots \\
3 \ldots \\
4 \ldots \\
5 \ldots \\
6 \ldots \\
7 . \\
8 . \\
9 \\
10 \ldots\end{array}$ & $\begin{array}{r}74 \\
49 \\
116 \\
40 \\
74 \\
88 \\
127 \\
184 \\
89 \\
54\end{array}$ & $\begin{array}{l}25 \\
17 \\
44 \\
13 \\
18 \\
43 \\
59 \\
44 \\
41 \\
20\end{array}$ & $\begin{array}{r}49 \\
32 \\
72 \\
27 \\
56 \\
45 \\
68 \\
110 \\
48 \\
34\end{array}$ & $\begin{array}{l}439 \\
376 \\
842 \\
336 \\
533 \\
503 \\
924 \\
608 \\
595 \\
359\end{array}$ & $\begin{array}{r}56 \\
36 \\
45 \\
26 \\
34 \\
67 \\
127 \\
91 \\
52 \\
41\end{array}$ & $\begin{array}{l}3 \$ 3 \\
341 \\
797 \\
310 \\
499 \\
436 \\
797 \\
517 \\
543 \\
318\end{array}$ & $\begin{array}{r}513 \\
426 \\
958 \\
376 \\
607 \\
591 \\
1.051 \\
762 \\
681 \\
413\end{array}$ & $\begin{array}{r}81 \\
53 \\
89 \\
39 \\
52 \\
110 \\
186 \\
135 \\
93 \\
61\end{array}$ & $\begin{array}{l}432 \\
373 \\
869 \\
337 \\
555 \\
481 \\
865 \\
627 \\
591 \\
352\end{array}$ & $\begin{array}{r}15.79 \\
12.44 \\
9.29 \\
10.37 \\
8.57 \\
18.44 \\
17.70 \\
17.72 \\
13.60 \\
14.77\end{array}$ & $\begin{array}{l}81.21 \\
81.56 \\
90.71 \\
89.63 \\
91.43 \\
81.56 \\
82.30 \\
82.28 \\
86.40 \\
85.23\end{array}$ \\
\hline $\begin{array}{l}\text { Total, trees } \\
1-10 \ldots . . .\end{array}$ & 865 & 324 & 541 & j. 516 & 575 & 4,941 & 6,381 & 899 & 5.482 & -14.09 & 85.91 \\
\hline
\end{tabular}

TABLE LI.-Sound and wormy fruit from 10 trees of Plat IV, unsprayed check, pear orchard of Mr. G. W. Langdon, Suisun, Cal., 1910.

\begin{tabular}{|c|c|c|c|c|c|c|c|c|c|c|c|}
\hline \multirow{2}{*}{ Tree No. } & \multicolumn{3}{|c|}{$\begin{array}{l}\text { Number of windfallen } \\
\text { pears. }\end{array}$} & \multicolumn{3}{|c|}{$\begin{array}{c}\text { Number of pears from } \\
\text { trees. }\end{array}$} & \multicolumn{3}{|c|}{ Total number. } & \multicolumn{2}{|c|}{ Per cent- } \\
\hline & Total. & Wormy. & Sound. & Total. & Worms. & Sound. & Total. & Wormy & Sound. & Wormy. & Sound. \\
\hline $\begin{array}{r}1 \ldots \\
2 \ldots \\
3 \ldots \\
4 \ldots \\
5 \ldots \\
6 \ldots \\
7 \ldots \\
8 \ldots \\
9 \ldots \\
10 \ldots\end{array}$ & $\begin{array}{l}372 \\
203 \\
433 \\
178 \\
391 \\
255 \\
505 \\
195 \\
562 \\
487\end{array}$ & $\begin{array}{l}370 \\
199 \\
420 \\
171 \\
386 \\
248 \\
496 \\
193 \\
533 \\
481\end{array}$ & $\begin{array}{r}2 \\
4 \\
13 \\
7 \\
5 \\
7 \\
9 \\
2 \\
29 \\
6\end{array}$ & $\begin{array}{l}169 \\
120 \\
151 \\
239 \\
348 \\
246 \\
214 \\
110 \\
289 \\
474\end{array}$ & $\begin{array}{l}158 \\
118 \\
136 \\
227 \\
326 \\
228 \\
195 \\
107 \\
255 \\
404\end{array}$ & $\begin{array}{r}11 \\
2 \\
15 \\
12 \\
22 \\
18 \\
19 \\
3 \\
34 \\
70\end{array}$ & $\begin{array}{l}541 \\
323 \\
581 \\
417 \\
739 \\
501 \\
719 \\
305 \\
851 \\
961\end{array}$ & $\begin{array}{l}528 \\
317 \\
556 \\
398 \\
712 \\
476 \\
691 \\
300 \\
788 \\
885\end{array}$ & $\begin{array}{r}13 \\
6 \\
28 \\
19 \\
27 \\
25 \\
28 \\
5 \\
63 \\
76\end{array}$ & $\begin{array}{l}97.60 \\
98.14 \\
95.21 \\
95.44 \\
96.35 \\
95.01 \\
96.11 \\
98.36 \\
92.60 \\
92.90\end{array}$ & $\begin{array}{l}2.40 \\
1.86 \\
4.79 \\
4.56 \\
3.65 \\
4.99 \\
3.89 \\
1.64 \\
7.40 \\
7.10\end{array}$ \\
\hline $\begin{array}{l}\text { Total, trees } \\
1-10 \ldots . . .\end{array}$ & $3 . j \& 1$ & 3.497 & 84 & 2,360 & 2,154 & 206 & 5,941 & $\bar{\jmath}, 651$ & 290 & 95.12 & 4. 88 \\
\hline
\end{tabular}


RESULTS.

The fruit from the 10 trees of the unsprayed check block was 95.12 per cent wormy and only 4.88 per cent were free from worms. Plat I (Table XLVIII) was sprayed three times and had only 5.80 per cent. wormy fruit, with 94.20 per cent free from worms, giving a difference of 88.40 per cent in the amount of fruit free from worms from the two. plats. Plat II (Table XLIX), which received the second and third applications (with the first spraying omitted, as given Plat I), showed 28.52 per cent wormy fruit and 71.48 per cent free from worms, as against 14.09 per cent wormy fruit and 85.91 per cent fruit freefrom worms for Plat III (Table L), which received the first and third applications, with the second spraying as given Plat I.

\section{SUMMARY AND RECOMMENDATIONS.}

There are practically two full broods of larvæ in the pear-growing. districts of the interior counties of California. Comparatively few of the first-brood larvæ go over the winter.

The number of first-brood larvæ being relatively small, the injury is not so noticeable, and many growers overlook the importance of destroying this brood of worms to prevent the greater damage by the more important second-brood larvæ, which begin to enter the fruit just prior to the first picking.

The first-brood larvæ begin entering the fruit about a month after most of the petals have fallen, though this time may vary somewhat with the season. All spraying for the first brood should be done within three to four weeks after the blossoms are off the trees. Two applications for this brood reduced the worms for the season from 9.62 to 18 per cent lower than the plats sprayed once.

Two, and preferably three, treatments are advised, using arsenate of lead at the rate of 4 pounds to each 100 gallons of water. The first application should be made as soon as most of the petals have fallen, and especial pains should be taken as nearly as possible to fill each calyx cup with the poison. A tower platform of the type shown in Plate III is very advantageous, because at this time many buds are pointing upward. The trees should be drenched. The second treatment should come three to five weeks after the falling of the petals. The third application should be given nine or ten weeks after the falling of the blossoms, or about two weeks before the first picking begins. If only two treatments can be given, the first and second of the above schedule should be given. 



\section{PAPERS ON DECIDUOUS FRUIT INSECTS AND INSECTICIDES.}

\section{VINEYARD SPRAYING EXPERIMENTS AGAINST THE ROSE- CHAFER IN THE LAKE ERIE VALLEY.}

By Fred JoHnson,

Agent and Expert.

INTRODUCTION.

The rose-chafer (Macrodactylus subspinosus Fab.), in most of the grape-producing sections of the eastern United States, is a vineyard pest of long standing. It has been the subject of experimentation. by numerous entomologists and horticulturists, who have employed against it at some time or other almost every insecticidal substance and method of combat in the whole category of insect remedies. In spite of all this experimental work, however, there is considerable skepticism among both vineyardists and entomologists regarding the complete success of poison-spray applications when the beetles are present upon the vines in large numbers. The results of vineyard experiments against this pest with a poison spray, undertaken by the Bureau of Entomology in the Lake Erie Valley during the season of 1910 , have proved highly encouraging, although by no means final. It is intended to verify this work during the coming season in the hope that the efficiency of the poison-spray method may be put to the severest test.

Some of the chief factors militating against the obtaining of decisive comparative data from sprayed and unsprayed portions of vineyards is the irregularity of infestation by the insect. This difficulty is increased by the fact that in order to secure best results from poison-spray applications it is very desirable that the poison be applied as soon as the first beetles appear in order that their first meal may consist of poisoned blossom-buds or foliage. Hence, unless one has an intimate knowledge of the direction from which the beetles invade the vineyard or the portions most heavily infested it is exceedingly difficult to lay out plats which will give an accurate comparison of the results of a spray treatment.

$71419^{\circ}-$ Bull. $97-12-5$ 


\section{HABITS OF THE ADULT.}

About the middle of June, just before the blossom-buds of the grape break into full bloom (fig. 16), the adult rose-chafers commence to appear upon the rines. They at once proceed to attack the blossom clusters and injure the unexpanded blossom-buds by cutting

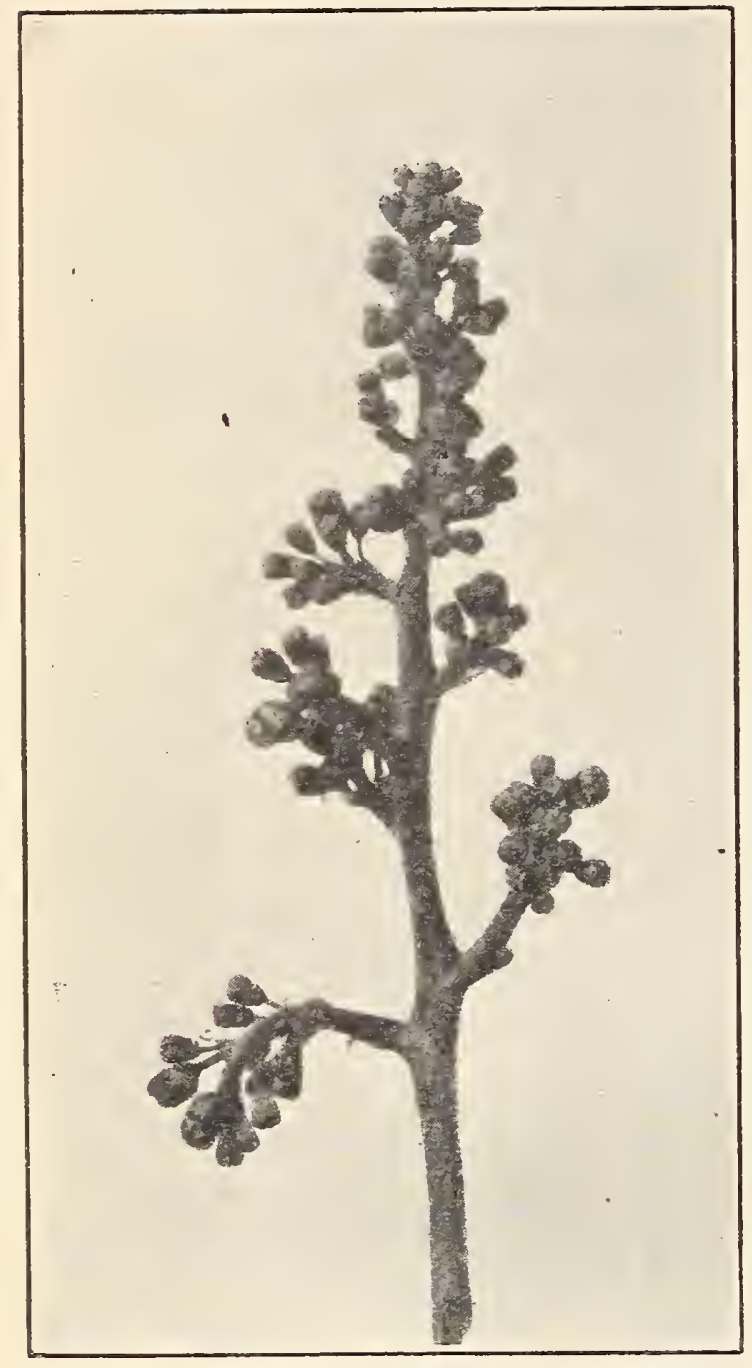

FIG. 16.-Condition of the grape blossombuds at the time the rose-chafer (Macrodactylus subspinosus) first appears, and when the first poison spray should be applied. Enlarged. (Original.)

$18, f)$ and the whole cluster will be quickly reduced to a frayed and blackened mass of broken and injured blossom-buds. Our observations lead us to believe that by far the greater percenta hole through the side of the bud and eating out or injuring the small ovary. (See fig. 17.) Since the blossom-buds are quite small, a single beetle will destroy a large number of blossoms, and if the beetles are at all numerous almost the entire crop may be destroyed. Sometimes in badly infested rineyards the blossom clusters will be swarming with a squirming mass of beetles (fig.

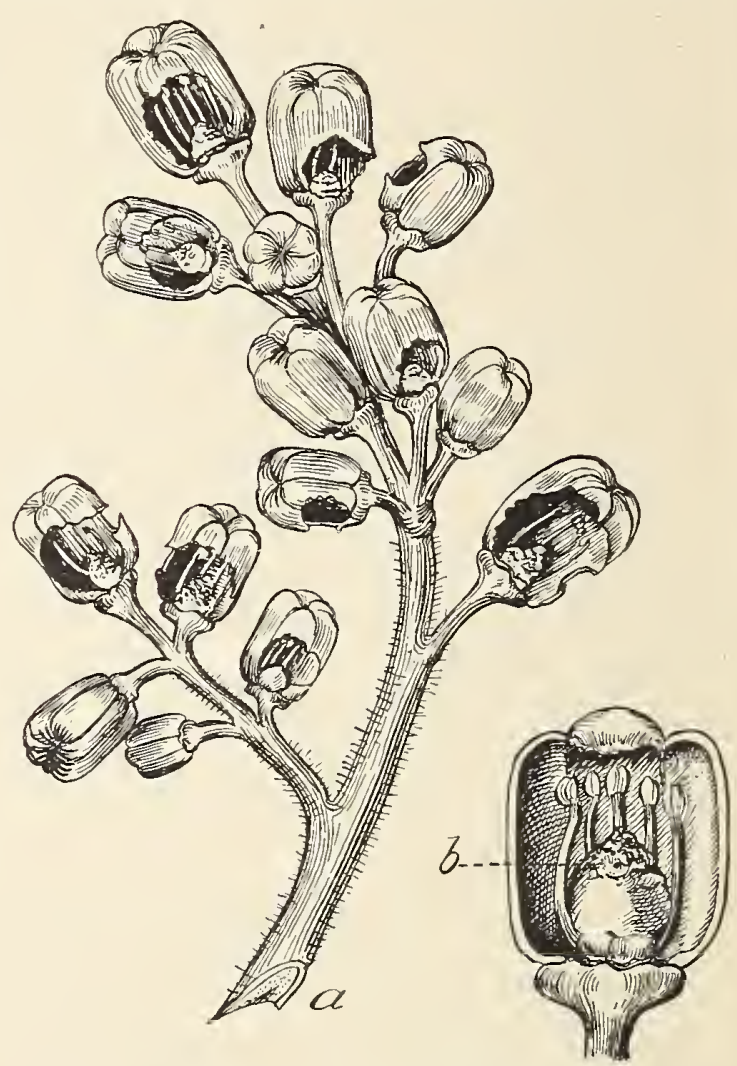

Fig. 17.- Work of the rose-chafer: $a$, Injury to grape blossom-buds by feeding of rose-chafer; $b$, injury to the ovary resulting in the destruction of the berry. Greatly enlarged. (Original.) age of injury to the grape crop is done previous to the opening of the blossom-buds and to a less extent while the grapes are actually in bloom and for a few days succeeding the blooming period. (See fig. 19.) Later, when the injured blossom-buds and berries have dropped, 
a very ragged fruit cluster is the result. (See figs. 20-21.) By the time the berries have attained the size of buckshot, or even smaller. the danger has practically passed. This danger period covers about three weeks, dating from about June 13 to July 5. It is, however, from about June 15 to 25 that the beetles appear in maximum numbers in the Lake Erie Valley, swarming into vineyards planted on Jight sandy soil from adjacent and rough sod lands and doing an immense amount of damage in a very short period. It is in the sandly soils of these pastures and rough sod lands along the lake shore that the insect breeds. Detached vineyards with general farm

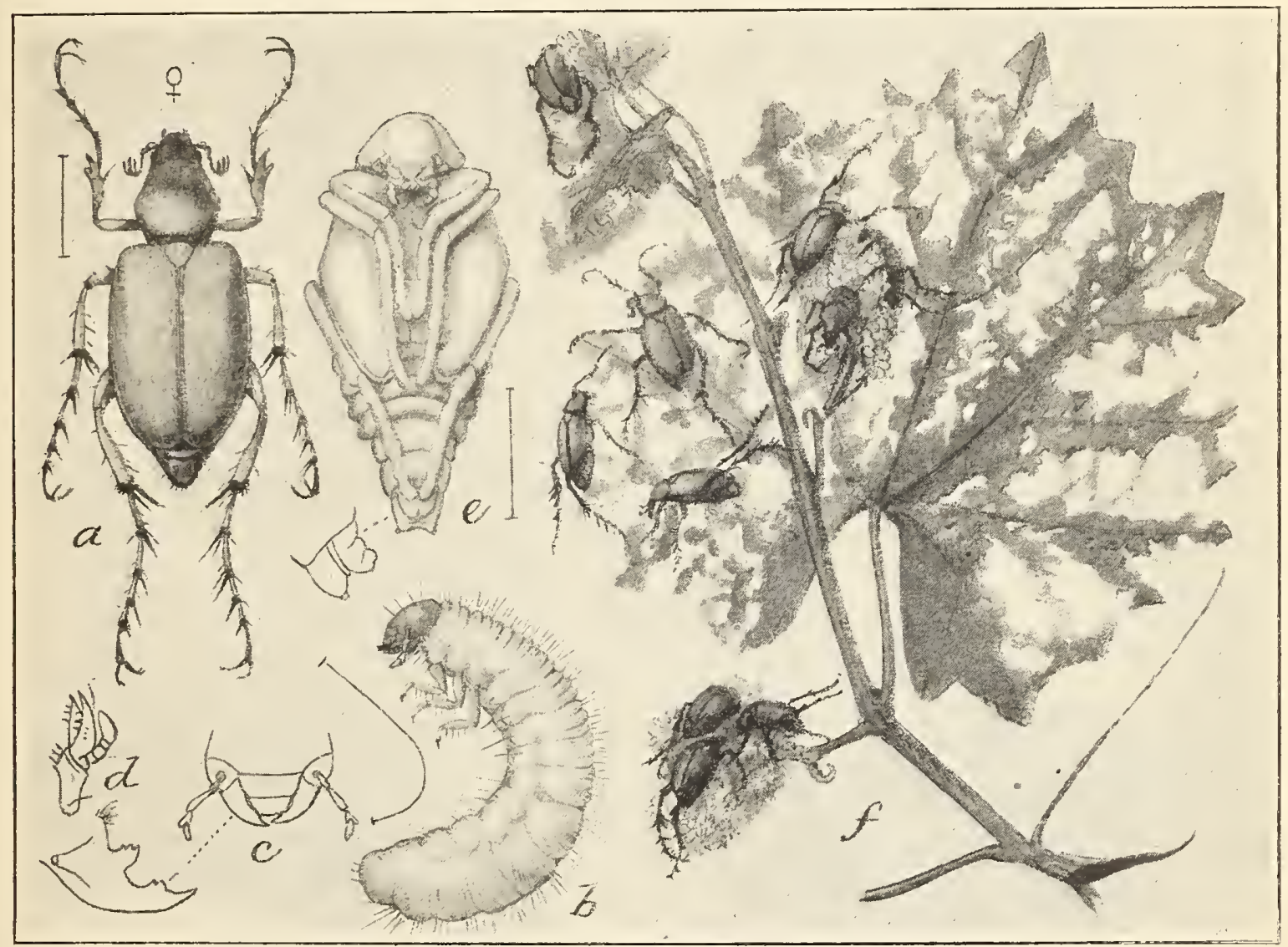

Fig. 18.-The rose-chafer (Macrodactylus subspinosus): a, Adult or beetle; $b$, larva; $c, d$, mouthparts of larva; $e$, pupa; $f$, injury to leaves and blossoms of grape, with beetles at work. $a, b, e$, Much enlarged; $c$, $d$, more enlarged; $f$, slightly reduced. (From Marlatt.)

lands intervening are much more likely to suffer from serious infestation than whe the rineyards are continuous and practically all of the soil is under clean cultivation. Thus there is an area in the township of North East, Pa., about 2 or 3 miles in length, lying parallel with the lake shore, where the soil is of a light gravel-andsand composition, which in former years was badly infested by rosechafers. Within the past few years practically all of the general farm lands of this area have been broken up and planted to vineyards. These vineyards are now subject to clean culture, with the result that there has been no serious invasion by this pest over this area for several seasons. 
Just beyond this strip of continuous rinevard, however, toward Moorheadrille, Pa., the vineyards are more scattered and the acreage surrounding them is deroted to the more general forage crops, such as grass, rye, corn, and other grains, together with considerable areas: of unbroken pastures and roodlots. These scattered rineyards hare alwars been menaced by the invasions of this pest from their adjacent breeding grounds and serious injury has frequently resulted to the grape crop.

The preralence of the rose-chafer orer this latter section has done much to discourage the planting of new rinerards, the general impression being that the insect can not be successfully or economically

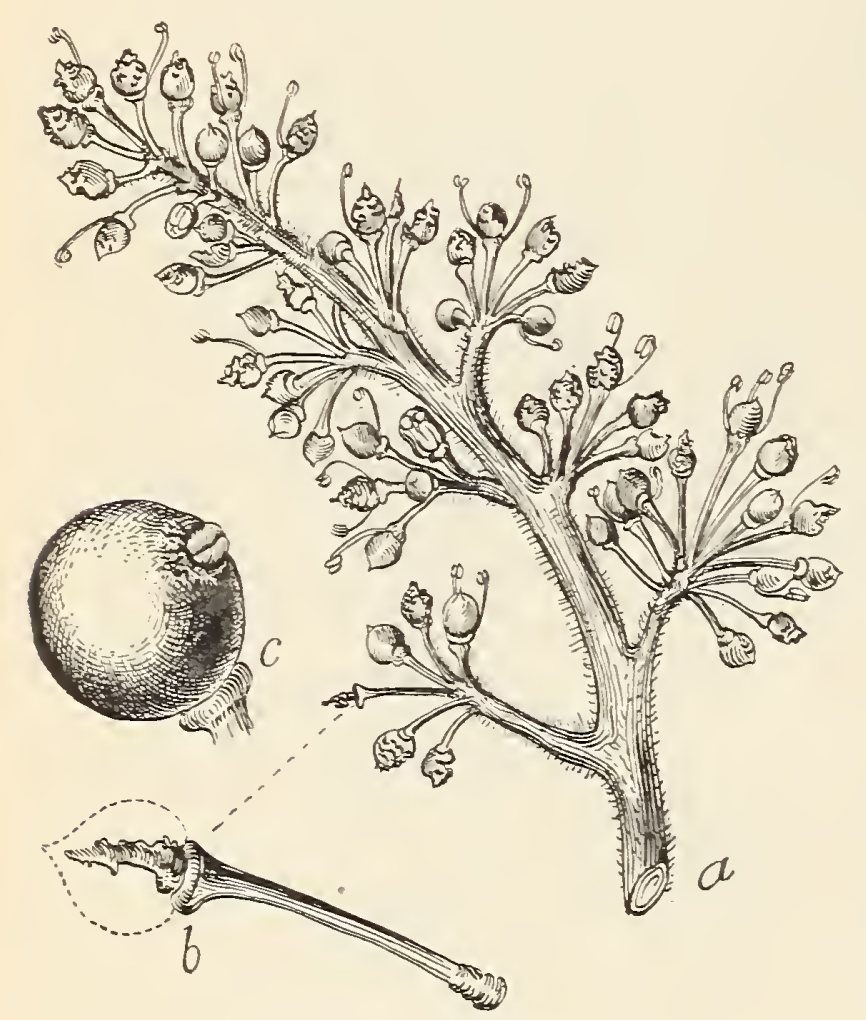

FIG. 19.- Work of the rose-chafer: $a$, Cluster showing small berries of grape injured by feeding of rose-chafer: $b$, berrs almost eaten : $c$, large berry slightly injured when small. showing seed protruding. (Original.) controlled. Handpicking the beetles has heretofore been the only control method employed, and has proved not only tedious and expensive, but only partially effective. It was upon rineyards in this "rosebug" 1 infested area along the lake shore that the spraying experiments of the season of 1910 were undertaken.

\section{HABITS OF THE LARVA.}

The larral stage of the insect (fig. 18, 6 ) is spent under ground, usually among the roots of grains and grasses. The female beetle (fig. 18, a) burrors into the sandy soil and deposits her eggs singly in small cells in the sides of the burrow. These burrors may be from 1 to 6 inches in depth, and the eggs are deposited irregularly in small cells in the walls of the burrow, the shallowest about onefourth of an inch from the surface, the deepest about $t^{*}$ inches belor. 'The newly hatched larræ may exist for some time on decayed regetation in the soil, but they soon attack the roots of grasses and other plants, and are seldom found in large numbers in soil receiving clean culture. They are, howerer, quite common in ill-kept sodcorered rineyards, and in digging about the roots of graperines for other insects single specimens of rose-chafer larre are found occa-

I A local name for the rose-chafer (Macrodactylus subspinosus Fab.). 
sionally in well-tilled vineyards, although never in sufficient numbers to become a menace to the grape crop. The larvio usually attain their full growth by late fall and at the approach of cold weather burrow down below the frost line, returning, in the following spring, to near the surface of the soil, where they make earthen cells, in which they transform to pupx (fig. 18,e) and then to the

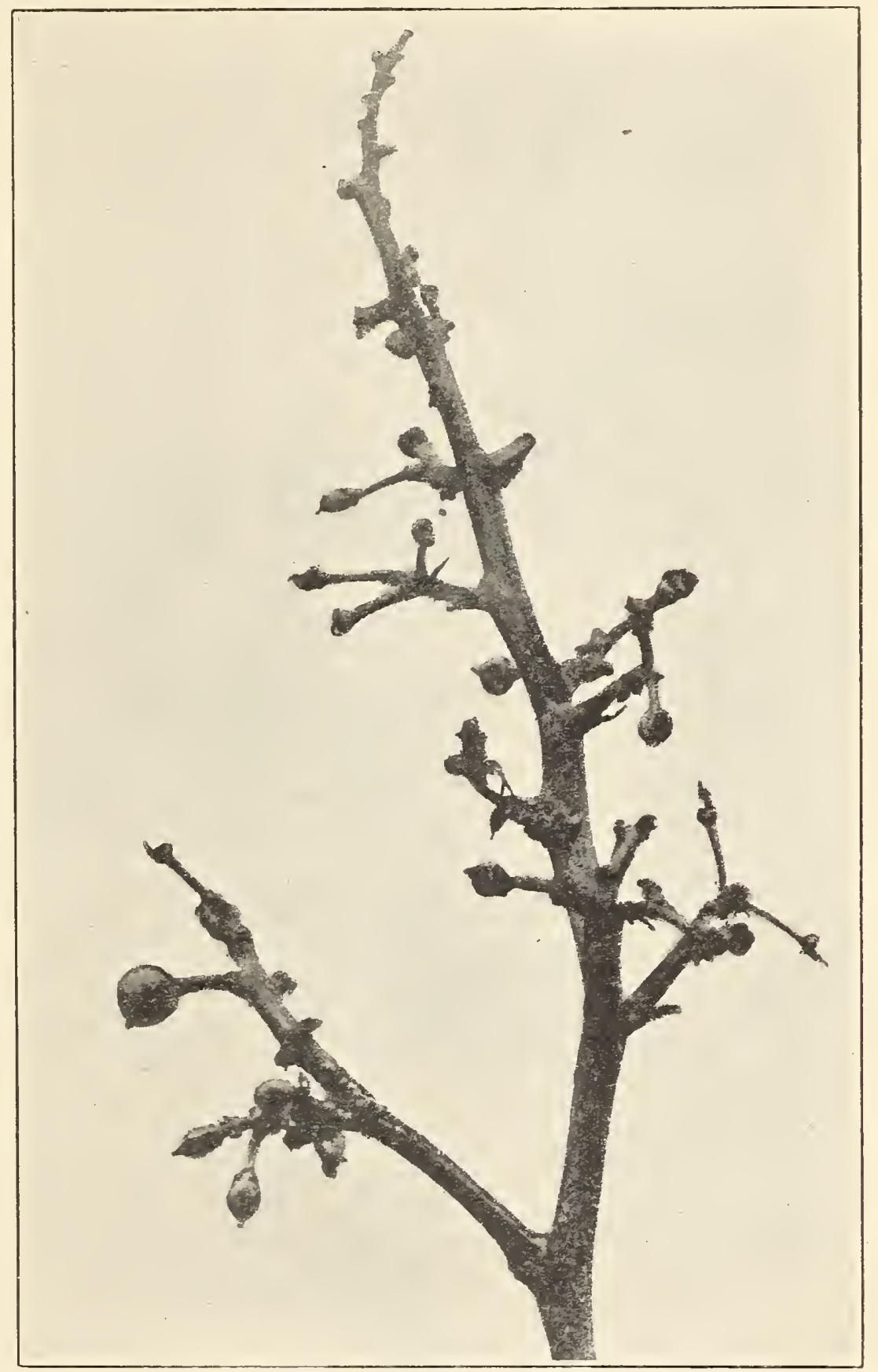

FIG. 20.-Grape cluster showing almost total destruction of berries through feeding of rose-chafer. (Original.)

adult beetles. These beetles emerge just before the blossom chusters of grapes are ready to break into full bloom.

\section{REMEDIAI MEASURES.}

HANDPICKING THE BEETIES.

The practice most commonly employed for the control of this pest in the past has been to handpick the beetles when they appear upon the vines. Since they are quite sluggish and cling somewhat tena- 
ciously to the blossom clusters large numbers of them can be destroyed in this manner. This method of control, howerer, necessitates that they be collected daily for a period of two or three weeks or as long as they are at all numerous. Where large areas are to be corered, handpicking becomes expensive and inrolves a great deal of time, and

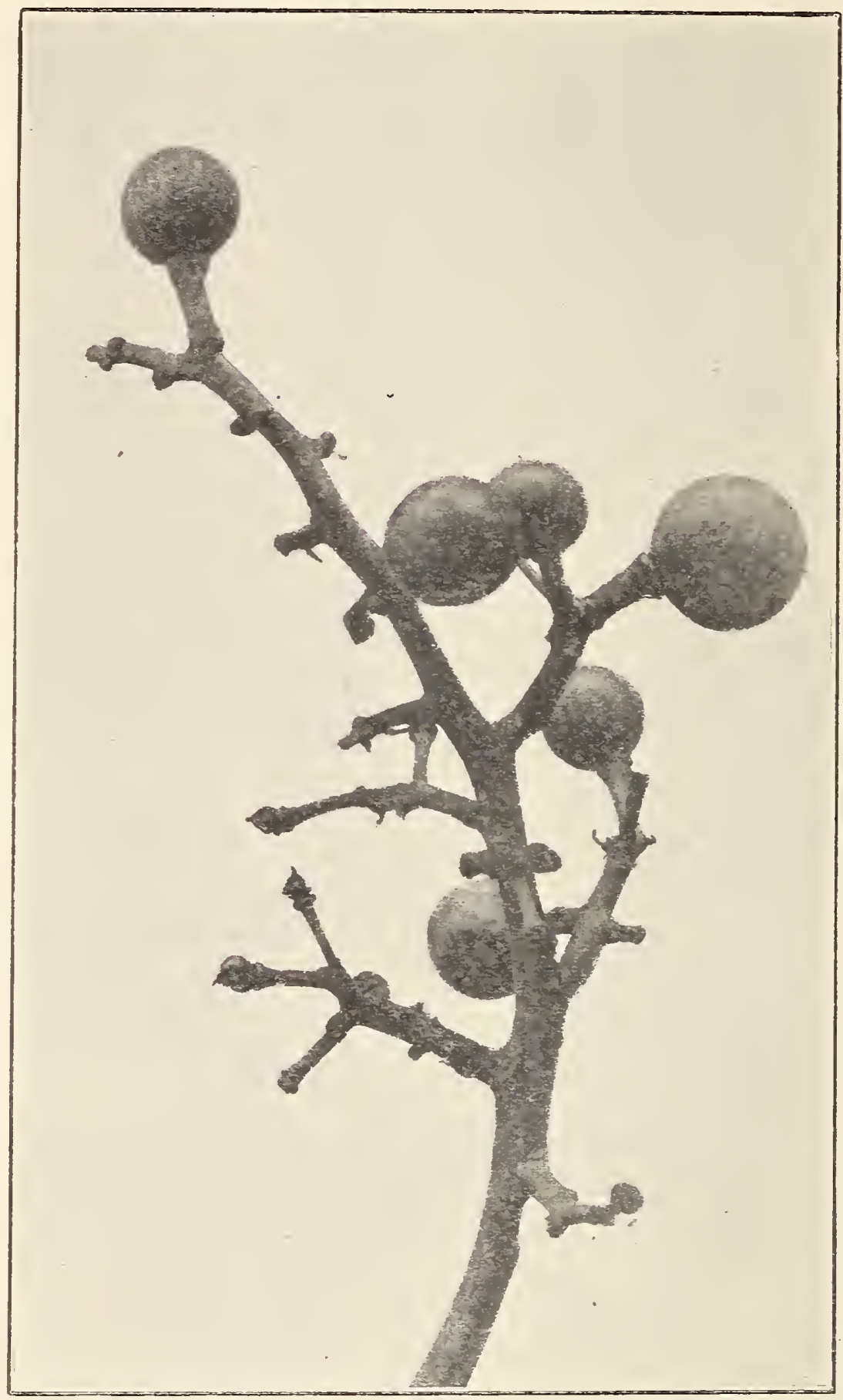

FIr. 21. -Grape cluster from which berries injured by rosechafer hare fallen. (Original.)

in adclition to this many of the beetles are not removed from the rines until they have accomplished more or less injury.

\section{SPRATIYG WITH ARSENICALS.}

Since the spraying of graperines for other insect pests, such as the grape rootworm and the grape-berry moth, has been shown to be effective and has become a common practice, increased effort has been 
made to control the rose-chafer by the same means and more or less experimentation along this line has taken place.

Cage experiments with arsenical poisons against the beetles seemed to indicate that a. large amount of arsenic was necessary to kill them. At a date previous to the general use of arsenate of lead heavy applications of arsenicals in some instances resulted in serious injury to the foliage of grapevines. This injury was caused by heavy applications of London purple, Paris green, and arsenite of lime, which are some of the more caustic forms of arsenicals. With the placing upon the market of reliable and properly-made brands of arsenate of lead, however, an arsenical is now available which can be used in large amounts without injury to the foliage of the vine. Hence there is now practically no danger of injury by arsenical burning, and in addition to this the arsenate of lead has a much greater adhesive quality than the other arsenicals previously mentioned, thus rendering its poisoning effect of longer duration.

In the field experiments against this pest during the past season, arsenate of lead was used in combination with Bordeaux mixture and in most instances at a strength of 5 pounds of arsenate of lead to 50 gallons of the spray liquid.

Experiments were undertaken in three vineyards covering 4 acres of grapevines on the farm of Page Bros., at North East, Pa., 4 acres on a vineyard owned by the Prospect Park Fruit Farms Co., and 3 acres on the farm of Mr. C. F. Hirt. Since this pest breeds outside the vineyards it is well-nigh impossible to predict, beforehand, either the extent of the infestation or the portions of the vineyard most likely to be infested, although the latter condition may be determined to some extent by close observations of local conditions orer several seasons, and since it is desirable that the first feeding of the invading beetles shall be upon poisoned blossom-buds and foliage this necessitates the application of the first spray on or about the time the first beetles appear. Thus at the time of selecting a vineyard for experimental work the extent of infestation likely to occur during the season is quite problematical. The only thing to be done is to select rineyards reputed to suffer annually from inyasions by this pest. In two of the experiments, those in the vineyard of Page Bros. and of Mr. C. F. Hirt, the first application was made before the grape blossom-buds had opened and before the beetles appeared.

The plat arrangement in the Page vineyard was as follows:

\begin{tabular}{|c|c|c|c|c|}
\hline Rows. & Bordeaux mixture. & $\begin{array}{l}\text { Arsenate } \\
\text { of lead. }\end{array}$ & Molasses. & Water. \\
\hline $\begin{array}{r}8 \\
12 \\
4 \\
16\end{array}$ & 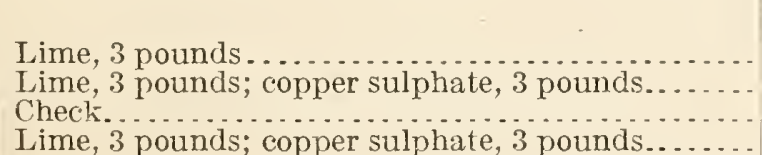 & $\begin{array}{r}\text { Pounds. } \\
5 \\
5 \\
5\end{array}$ & $\begin{array}{l}1 \text { gallon ....... } \\
1 \text { gallon....... } \\
\text { None............ }\end{array}$ & $\begin{array}{l}50 \text { gallons. } \\
50 \text { gallons. } \\
50 \text { gallons. }\end{array}$ \\
\hline
\end{tabular}


Two applications were made; the first on June 17 , before the beetles appeared, and the second on June 23. Infestation on the vinerard proved to be rather light, and only on the ends of the rows on the west side of the vineyards which adjoined lands given over to the production of grain crops were the beetles at all numerous. ITence there was not a very marked difference between the amount of injury on the sprayed and the check plats, with the exception of a fer rines on the ends of the rows where the infestation was heaviest. Here the clusters on the untreated vines were quite ragged as a result of injury by the beetles, whereas upon the treated rows no injury was apparent. In previous years it had always been the custom of the owners of this rineyard to handpick the beetles. This season no handpicking was done. On a near-by vineyard on the same farm. howerer, where handpicking alone was depended upon, the injury by the beetles was much more in evidence, and the owners were very sorry that they did not resort to arsenical spraying instead of handpicking, and have expressed their intention to rely upon spraying as a means of rose-chafer control in the future.

The vineyard of Mr. C. F. Hirt, in which another experiment was undertaken, is located on sandy soil on the banks of Lake Erie. It is entirely isolated from other vineyards and is adjacent to pastures and general farm lands, and has the reputation of being one of the worst infested vineyards in this rose-chafer infested area. Several years ago the vineyard was practically abandoned on account of the injury done by the rose-chafer. During the past three or four years, howerer, efforts have been made to control the pest in this vineyard by handpicking; yet in spite of this, beetles wrought considerable injury to the crop. At the opening of the past season the owner was prevailed on to try out the poison-spray method as a means of control, with the understanding that no handpicking was to be done. Accordingly the vineyard. which consists of about 3 acres, was treated in the following manner:

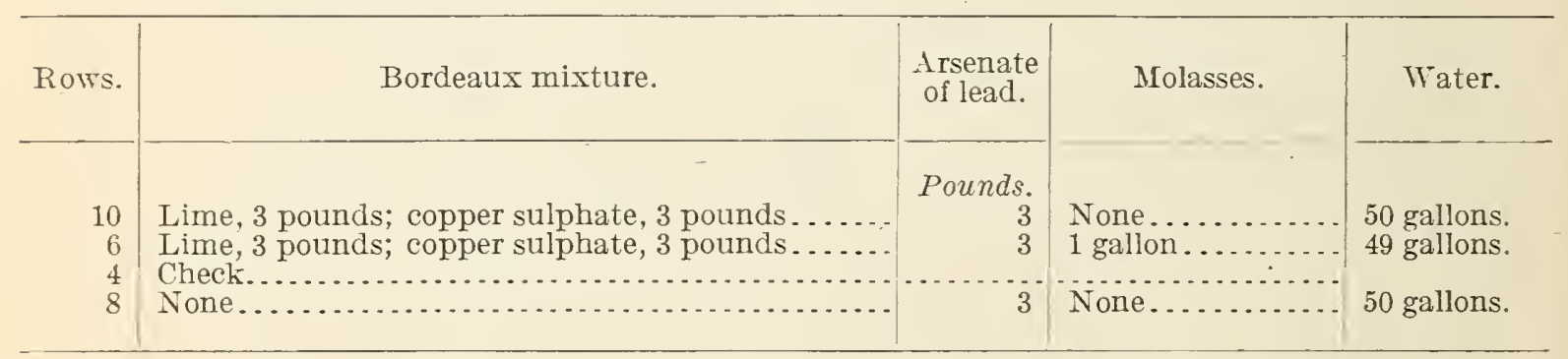

Three spray applications were made, the first on June 8, before the blossom-buds had opened (see fig. 16) and bafore any beetles appeared. The object of this application was to thoroughly coat all of the blossom-buds and the new growth of foliage, which was comparatively easy at this date. as the graperines had not as yet made a very luxuriant growth. The second application was made June 17, when the first beetles appeared upon the vines, and a third on June 


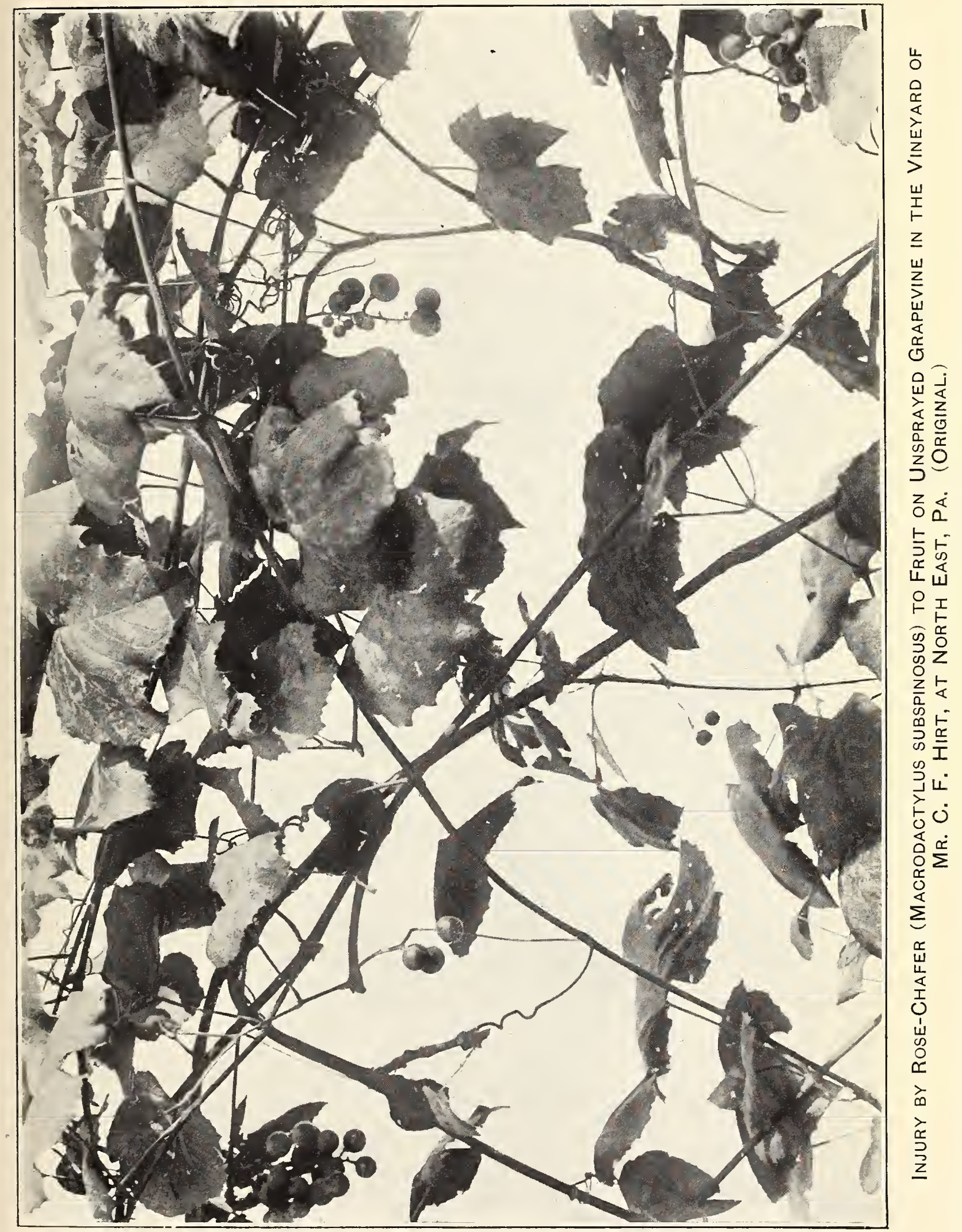




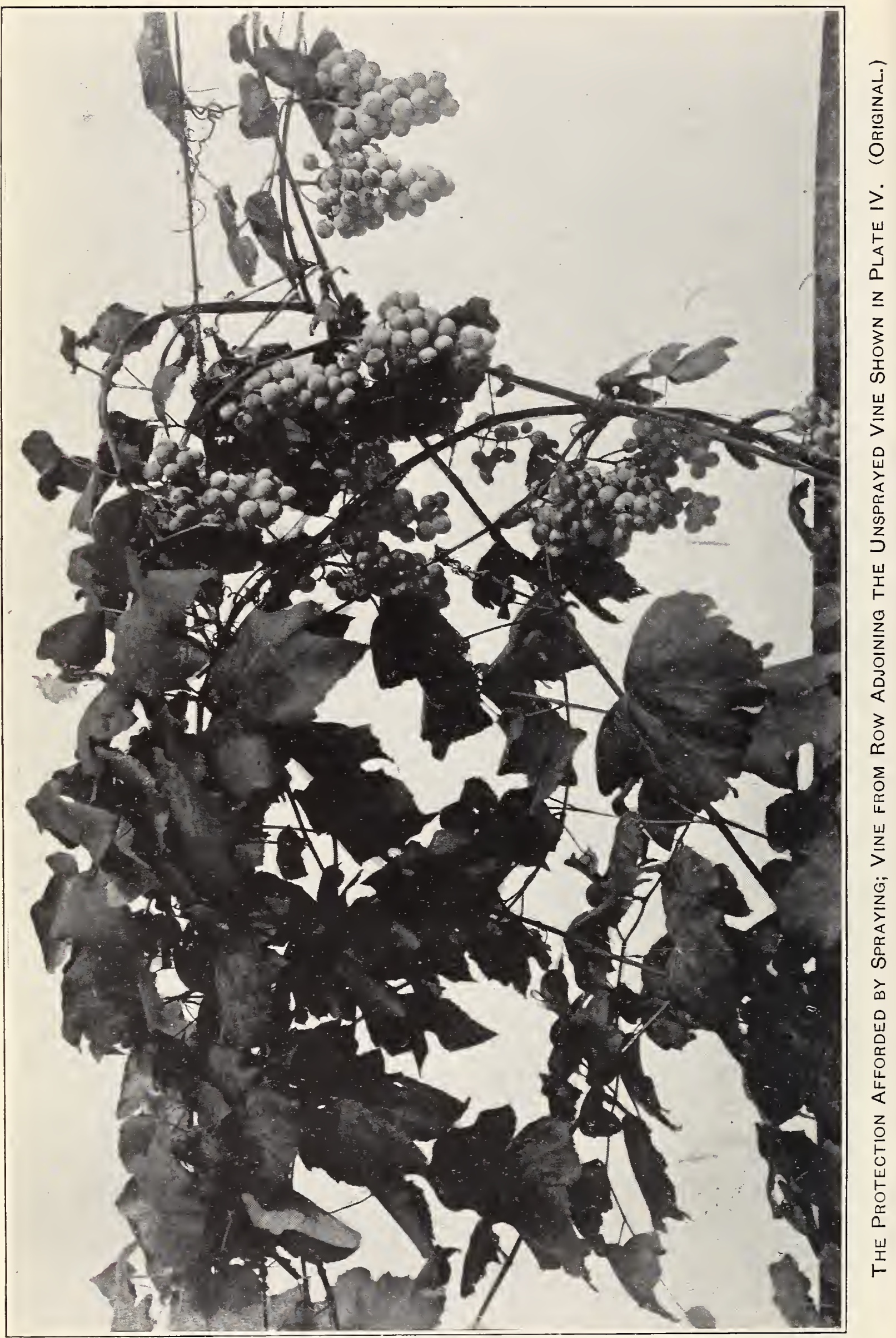




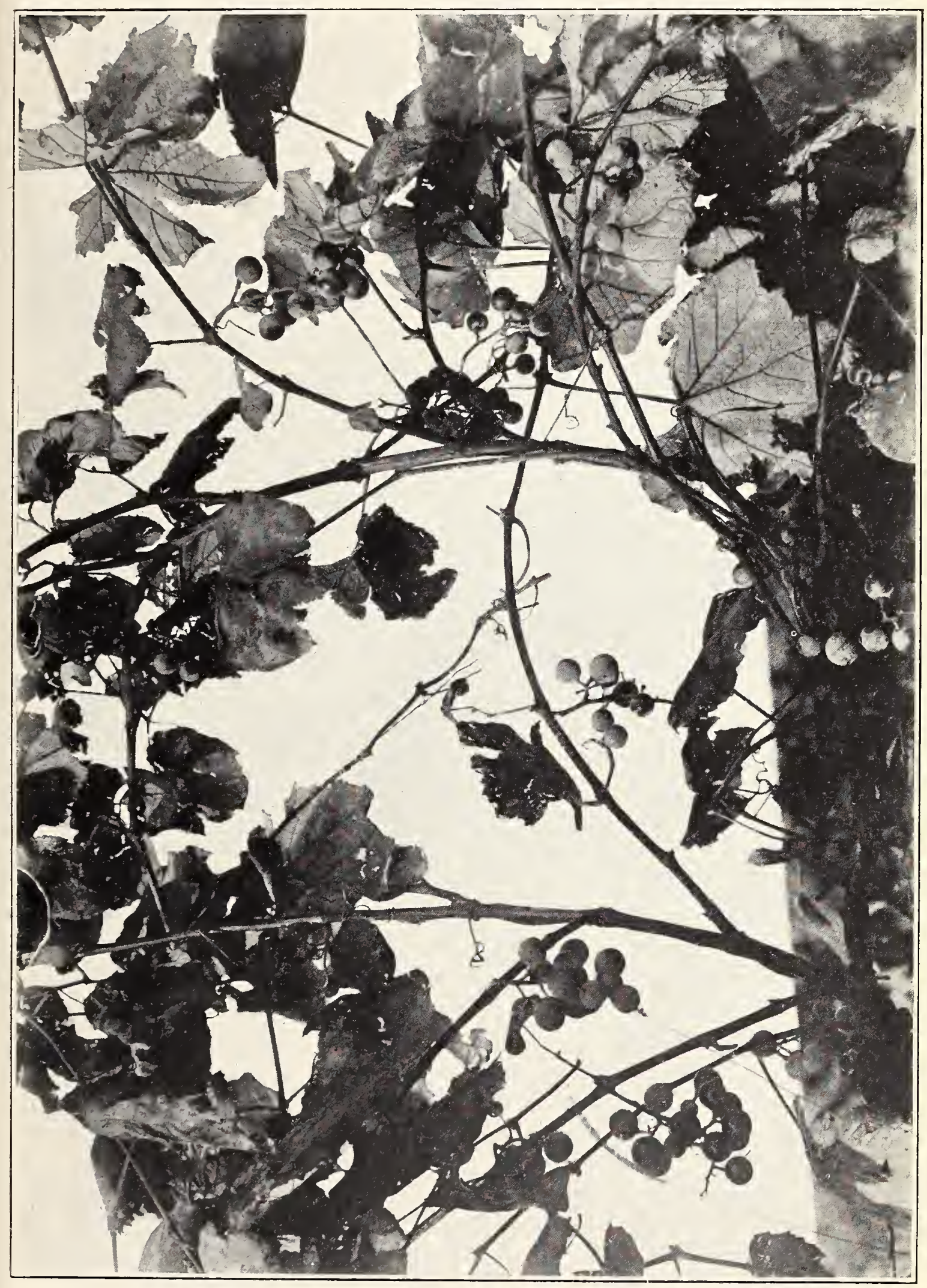

\&

5

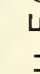

I

z

\&

ปั

嵌

$\stackrel{\dot{x}}{\Sigma}$

눙

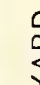

㐫

$>$

닌

늠

는

$>$

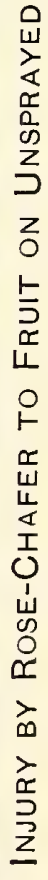




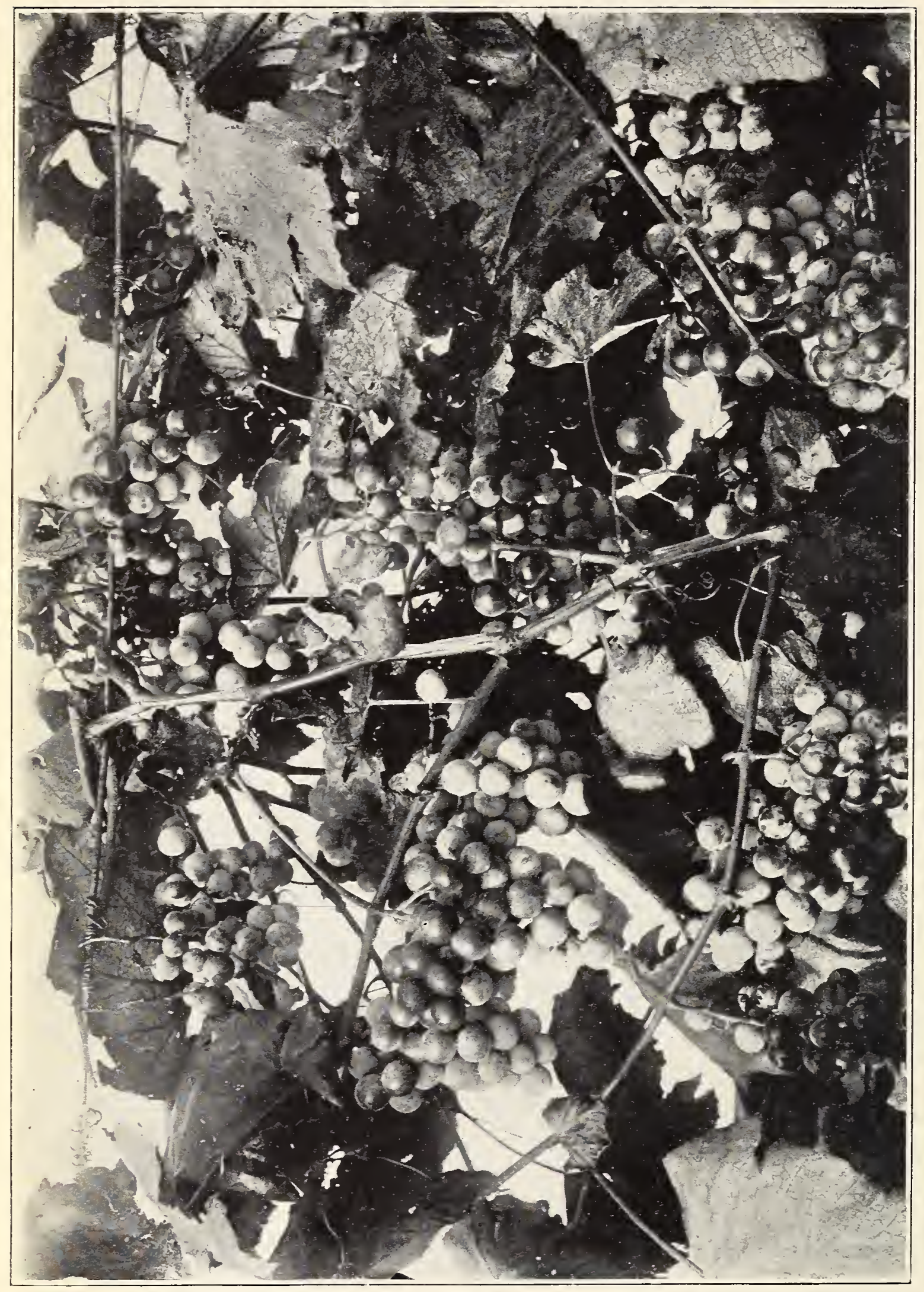


24, which was about the height of the rose-chafer season in that ricinity.

At no time during the active season did the writer"s visits reveal a heavy infestation of beetles upon this vineyard, although the beetles were rather numerous between the dates of June 17 and July 5 in adjoining pasture lands and upon the sumacs growing along the edges of the rineyard. Unfortunately, the check rows ran through that portion of the vineyard which proved to be least infested by the beetles and but slight injury was evident upon them. Portions of two rows on the worst infested side of the vineyard, however, were left unsprayed, and on these untreated rines the crop was practically ruined. Plates $I V$ and $V$ show the fruit clusters on untreated and treated vines in this vineyard from adjoining rows in the worst infested portion of the rineyard.

The result in crop yield for the whole vineyard, which comprises an area of about 3 acres, was far in excess of the yield for preceding years when the handpicking method of control had been employed. The owner stated that in the three preceding years the total annual yield had not exceeded 3 tons of fruit, whereas in the season of 1910 , when the average vineyard yield for the grape belt was notably short, this vineyard yielded $5 \frac{3}{4}$ tons, an increase over preceding years of $2 \frac{3}{4}$ tons.

The spray applications were made with a gasoline-engine vineyard sprayer, using stationary nozzles and carrying a pressure of about 125 pounds, and applying about 100 gallons of liquid per acre.

Only one application was made on the vineyard of the Prospect Park Fruit Farms Co., on their farm located near the vineyard of Page Bros., at North East, Pa. This spray consisted of the Bordeaux mixture made from 3 pounds of lime and 3 pounds of copper sulphate, 5 pounds of arsenate of lead, and 50 gallons of water, and was made June 21, after some injury had been done by the beetles. On account of this injury preceding the spray application it was not expected that the results obtained would be worth recording. Yet as the season advanced the crop of fruit in this vineyard showed a great improvement over that produced in an adjoining untreated vineyard only a few rods distant. Plates VI and VII show vines taken at random from these two vineyards. In the former instance the crop scarcely paid for harvesting; from the latter crop a very good profit was secured.

Still other indications of the value of arsenical sprays in the control of the rose-chafer have been observed. On the farm of Dr. R. Kelly, at Moorheadville, Pa., is a vineyard which for many years had been badly injured by rose-chafers, and in which handpicking the beetles had been only a partially successful means of control. Three seasons ago at the suggestion of the writer the owner resorted to the arsenical-spray method of control, using 5 pounds of arsenate 
of lead to 50 gallons of Bordeaux mixture. The first application was made before the blossom-buds opened, and two later applications were made, applying them at the time of appearance of the beetles in injurious numbers. This methor of control has been conducted in this rineyard for three consecutive seasons, and the owner states that he is satisfied with the results that he has obtained and considers it far more effective and less expensive than the handpicking method of control.

Located at Girard, Pa., is a vineyard of $t 0$ acres, under the management of Mr. M. C. Kibler, which is subject to the attacks of rosechafers erery season. This rineyard was visited on June 23, 1910, at which date about 20 momen and girls were engaged in handpicking the beetles from the entire area. The whole rineyard had been gone orer daily in this manner for a week previous to our visit, yet there was eridence of considerable injury by the beetles. At this date Mr. George F. Miles, of the Bureau of Plant Industry, was making Bordeaux-mixture applications on sereral acres for control of the black-rot fungus. Five pounds of arsenate of lead were added to the Bordeaux mixture applied to this area. When the party of women who were handpicking the rose-chafers did the collecting orer the sprayed area on the following day, they found only a small number of beetles there as compared with the number found on the unsprayed parts of the vineyard.

THE CSE OF SUEETENED ARSENICALS.

In the summer of $190 \pi$ it was reported that an arsenical spray that had been sweetened with cheap molasses had proved effective in poisoning the rose-chafer in the rineyards in Michigan. In September of that rear the mriter risited Mr. Frank Stainton, at Lamton, Mich., who was reported to have used this sweetened arsenical. In conversation with Mr. Stainton it was discovered that this sreetened ar'senical was a proprietary mixture made by a local doctor. Mr. Stainton stated that he receired a sample of it rather late in the season and applied some of it to rosebushes infested by the rosechafer. The beetles appeared to be attracted to the sweetened poison, eating it in apparent preference to the flowers of the plant, and clied shortly after. Upon analysis this streetened arsenical was found to consist of arsenite of lime and molasses. Mr. Stainton expressed his intention to use streetened arsenite of lime against the rose-chafer in his rineyards during the season of 1908. In the spray experiments conducted in the rineyard of Dr. R. Kelly, at Moorheadrille, Pa., in 1908, against the rose-chafer, 1 gallon of molasses was added to 50 gallons of Bordeaux containing arsenite of lime made according to Kedzie's formula ( 4 ounces of white arsenic to 50 gallons of the abore-mentioned sweetened mixture). One gallon of molasses tras also added to Bordeaux mixture and arsenate of lead, and in addi- 
tion to this a third plat was sprayed with arsenate of lead and Bordeaux containing no molasses. In this work it was not possible to detect that the beetles exhibited a greater preference for the foliage or blossom clusters sprayed with the sweetened arsenical, nor was there evidence of a greater benefit from rose-chafer protection on the plats sprayed with the sweetened arsenicals as against the plat sprayed with the unsweetened arsenical. Where the arsenite of lime was applied there was evidence of a slight burning of the tender foliage, which was not apparent where the arsenate of lead was used. During the seasons of 1909 and 1910 the writer used, on adjoining plats, molasses and arsenate of lead with the Bordeaux mixture, and also arsenate of lead unsweetened and Bordeaux mixture, employing in both cases $\check{5}$ pounds of arsenate of lead to 50 gallons of the mixture. In none of these experiments was there detected any decided benefit from the presence of the molasses. Reports are persistently circulated that good results have been secured by the addition of some sweetening substance, either molasses or glucose, and since the rose-chafers feed upon the flowers and nectaries of grapes and other fruits it is reasonable to suppose that the presence of a sweetened substance in the spray would attract them. The increased expense of the molasses is but slight, and it is suggested that the vineyardist using arsenicals in combating the rose-chafer employ a sweetened arsenical on a portion of his rineyard and compare results with a portion treated with an unsweetened arsenical. Until more data is at hand on this subject the writer, while not wishing to discourage the use of a sweetened arsenical against the rose-chafer, feels that the results which have come directly under his observation do not appear to justify the recommendation of its general use.

TIME TO MAKE THE SPRAY APPLICATIONS.

In regard to the cost of spray application for the control of this pest, it should be pointed out that the entire cost should not be charged to rose-chafer control, since it is highly desirable that a spray application be made before the blossom-buds expand against the grape-berry moth (Polychrosis viteana Fab.), and also for fungous diseases. The later spraying just after blossoming is also necessary against the grape rootworm (Fidia viticida Walsh). No additional spray applications were made on the rineyard of $\mathrm{Mr}$. F. C. Hirt after June 24. Yet there was practically no eridence of feeding by the beetles of the grape rootworm on the treated portion of the vineyard, nor was there any evidence of mildew on these rines, whereas on the untreated check rows there was a large amount of feeding by the grape rootworm beetles, and the clusters of fruit were also very badly mildewed. Hence the evidence secured during the past season indicates that if rineyardists, in regions. where the rosechafers commonly occur in injurious numbers, will resort to a thor- 
ough spray application with arsenate of lead and Bordeaux mixture before the blossom-buds of the grape expand (fig. 16); and once $\mathrm{or}^{*}$ trice during the period when the rose-chafers are most numerous. they can not only prevent serious injury to the crop by this pest. but also control the depredations of sereral other cheming insects.

CLEATING LP BREEDIYG PLACES.

In addition to spraying as a means of control for this pest, much good can be done by breaking up pastures and rough sod lands adjacent to rinejards in infested areas. An illustration of this method of control was obserred during the past season. In the early summer of 1909 a field of 30 acres of pasture land on the farm of Mr. R. McBroon, at North East, Pa., which is located in the rose-chaferinfested area along the lake shore, was broken up and planted to rineyard. Large numbers of larræ and pupæ rere found in the sod at the time of plowing. During the summer of 1909, after the rines rere planted, the soil was subject to clean culture. During the summer of 1910 numerous examinations of the soil rere made in this rineyard in search of larra and pupæ, but none ras found. Tet in the sod lands adjacent to this vineyard the beetles and larræ were as numerous as in previous years. Unfortunately; it frequently happens that rough land and pastures adjacent to rineyards are not controlled by the owners of infested rineyards. Then such conditions exist it is necessary to resort to direct methods of control, and observations corering sereral seasons indicate that thorough spray applications with arsenate of lead will prore an effective means of controlling the rose-chafer in infested rineyards.

\section{SUIVIIARY.}

On account of the limited areas of infestation in any particular rineyard section the rose-chafer has not receired the consideration it deserres as a destructive rineyard pest. In the aggregate its injuries to the grape crop in the grape-producing areas of the United States are very large, and it is hoped that the experimental work now in progress will lead to the adoption of more effectire means of control. Since it has become the practice to spray graperines for the grape-berry moth (Polychrosis viteana), and also for fungous diseases at the same time that the adult rose-chafers attack the blossombuds, erery effort should be made by rineyardists to combat this pest at the same time. The experiments conducted by this bureau during the past season indicate that a rery thorough application of arsenate of lead when the beetles appear, just before the blossoms open, will reduce its destructireness to the extent that a profitable crop of fruit can be secured eren in rineyard areas where this insect pest abounds in destructive numbers. 


\section{PAPERS ON DECIDUOUS FRUIT INSECTS AND INSECTICIDES.}

\section{THE CALIFORNIA PEACH BORER. ${ }^{1}$}

(Sanninoidea opalescens Hy. Erw.)

By Dudley Moulton, Formerly Special Agent.

\section{INTRODUCTION.}

The California peach borer (Sanninoidea opalescens Hy. Edw.; fig. 22) has been the subject of investigation by the Bureau of Entomology since the summer of 1907 . The writer, however, had observed its habits and the various methods used in its control for several years previous to that time and vividly recalls spending many hours in his father's orchard digging "borers" from the trees and later applying the protective washes. As a boy he was taught that this practice was quite as necessary in the general scheme of orchard treatment as was pruning or cultivating. This insect has been a menace to fruit growers in the Santa Clara Valley from the very beginning of the fruit-growing industry and the constant care and the disagreeable labor which accompanies the digging of the borers has led many orchardists to become intimately well acquainted with it in the larval or borer condition. (See Pl. VIII.) Many men of their own accord have experimented with various methods of control. Orchardists seldom recognize the adult moths and know little about their habits, although they know the larval stage so well.

The California peach borer derives its common name from its close relationship to the peach borer of the East (Sanninoidea exitiosa Say), and from the fact that it is primarily an enemy of the peach and other closely related plants. Systematically, the species is closely related to the eastern peach borer, and it is difficult to distinguish the two species by comparing the larval stages alone. The female moth of the eastern form, however, is readily distinguished from the moth of the western species by the presence of conspicuous orange

I The present paper gives the results of observations on the California peach borer made by Mr. Moulton. while engaged in deciduous fruit insect investigations in the Bureau of Entomology and located at San Jose, Cal. 
bands extending across the fourth and fifth abdominąl segments, these bands not being present in the western form. The eastern insect has been known as an enemy to peach trees in the Eastern States for almost 200 years, as is evidenced by the numerous accounts which have appeared in horticultural and entomological journals. It is distributed throughout the eastern and middle-western peachgrowing sections and undoubtedly has been introduced into California on nursery stock, although it does not yet seem to have become established there. The California and eastern borers choose similar food plants and attack and injure trees in the same ways, and the methods of control are therefore similar. The California borer is apparently a western American form exclusively and a native of the Western States. It is considered a serious pest only in limited areas in the San Francisco Bay district.

The writer endeavors to discuss in this paper what is known of the distribution of the California peach borer, its life history, its food plarits, its parasites, and the best known artificial measures of control. He wishes to express his thanks to those of his associates, Messrs. Charles T. Paine and P. R. Jones, who have at different times helped in making the life-history records, and to various orchardists who have furnished trees for the purpose of experiments and who have helped to make the work practical.

\section{DISTRIBUTION AND FOOD PLANTS.}

\section{DISTRIBUTION.}

The California peach borer has been known to entomologists since 1881, when Henry Edwards collected a few specimens and described the species as Egeria opalescens, ${ }^{1}$ and since then it has been known variously as Sanninoidea opalescens and S. pacifica Riley. In his first account of the insect, Henry Edwards told of having collected three male specimens in Virginia City, Nev., and he also had one type female, which had been collected-by Morrison and was listed from Colorado. Later, Beutenmüller gave, as the habitat of the species, Oregon, California, and Nevada. Mr. F. X. Williams, formerly of the California State Commission of Horticulture, has collected one specimen at Donner Lake, Nevada County, Cal., at an elevation of 6,000 feet. He has also collected many specimens in flight near Castello, in Shasta County, at an elevation of 2,000 feet. Other collectors of Lepidoptera have also taken it in these same mountainous sections of California. The insect is known as a pest only in the Santa Clara Valley and in Alameda and San Mateo Counties, whose areas lie close around the southern arm of San Francisco Bay. 
NATIVE FOOD PLANTS.

Mr. J. G. Grundell, who has been a resident in the mountains above Alma, Santa Clara County, since 1894, has many times collected moths on the wing in the foothills lying above the Santa Clara Valley, and he has furnished the only positive record of the rearing of this species from any native plants. Mr. Grundell was at one time experimenting in his little mountain orchard with cuttings of the western chokecherry (Cerasus demissa) as a native grafting stock for cultivated fruit varieties. This plant suckers readily and these suckers were cut and planted to be used as stocks for grafting. Mr. Grundell, by keeping such cuttings as became naturally infested confined in jars, was able at many times to rear adult moths of the California peach borer. The western chokecherry is indigenous to the Sierra Nevada Mountains, middle North Coast Range (Napa Mountains), Oakland Hills, Mount Hamilton -Range, and the Santa Cruz Mountains, and it is undoubtedly one of the common native food plants of this insect.

\section{HISTORY OF FRUIT GROWING IN THE SANTA CLARA VALLEY.}

Mr. Grundell says that he has never collected or found the moths in flight in deep woods, but that they seem rather to seek the open or bushy country. He states also that the insect was most easily collected in the hills immediately at the edge of the Santa Clara Valley, and it was here, in the adjoining valley, that the insect first became injurious. The lower foothills and the upper western areas of the Santa Clara Valley were at one time covered with a dense growth of underbrush, which included especially the western chokecherry. Beginning about the year 1880 this land was gradually cleared and planted to orchards. Thus the cultivated varieties displaced some of the insect's native food plants in its native habitat. It was therefore natural for the insect to adapt itself to those cultivated plants which were closely related to the native varieties, and to extend its habitat into the open and adjoining country. The soil and climate are here especially well adapted to the growing of deciduous fruits, such as peaches, apricots, cherries, and plums, and the entire valley is now practically one continuous orchard. The insect attacks all of these species quite freely and here finds ideal conditions in which to live.

\section{LIMITS OF AREAS IN WHICH INJURY OCCURS.}

The writer can not understand why an insect which is so widely distributed throughout the western coast States should be so local in its injury in cultivated orchards. The Santa Clara Valley, the areas on either side of San Francisco Bay in Alameda and San Mateo Counties, and small areas near Watsonville, Santa Clara County, are 
the only places where the peach borer has become a pest. Other peach, apricot, and plum sections in the Napa, Sonoma, Suisun, and San Joaquin Valleys and on the western slopes of the Sierra Nevada Mountains are not troubled at all.

VARIETIES OF CULTIVATED FRUITS ATTACKED; RESISTANT BUDDING AND GRAFTING STOCKS; SOIL CONDITIONS AS BEARING ON INFESTATION.

The peach borer is eminently a root-boring pest, and two factors, therefore-the kind of root stocks upon which the trees are growing, and the nature of the soil- - determine largely the amount of damage that the borers will inflict. Peach and apricot stocks are most susceptible to attack, although almond, cherry, apple, and native plums are less so; and the wild plum, known as the Myrobalan or cherry plum (Prunus cerasifera) is almost entirely exempt. Myrobalan plum seedlings are imported in great quantities from Europe and they are now recognized as one of the best stocks upon which to graft domestic plums. This stock is especially susceptible to attack only when a tree has been weakened by some cause such as a lack of water or cultivation or when it has been partly killed by "gophers" or other rodents. Almond stocks are more or less resistant if planted in soils suitable to their growth. Borers appear to attack trees more readily when they are planted in soils of a light sandy or gravelly texture. The writer does not believe that newly hatched larvæ can reach the lower crowns or roots more easily in light than in the heary soils of loam or clay; it appears, rather, that the trees themselves are not so strong and are therefore not so resistant.

DESCRIPTIONS, SEASONAL HISTORY, AND HABITS.

THE EGG.

DESCRIPTION.

The egg of the California peach borer measures approximately $0.72 \mathrm{~mm}$. in length and $0.44 \mathrm{~mm}$. in width. It is flattened and depressed on the sides and is depressed at one end. The eggs are chestnut to dark-brown in color and when magnified the outer surface has a stippled and mosaic appearance. The sculpturing so characteristic of the eggs of the eastern peach borer ${ }^{1}$ is also apparent on the eggs of the California peach borer (Sanninoidea opalescens).

DEVELOPMENT AND HATCHING.

The writer was able to make constant and daily observations on oviposition by moths which were confined in out-of-door rearing cages built over small apricot and peach trees in the back yard of the 


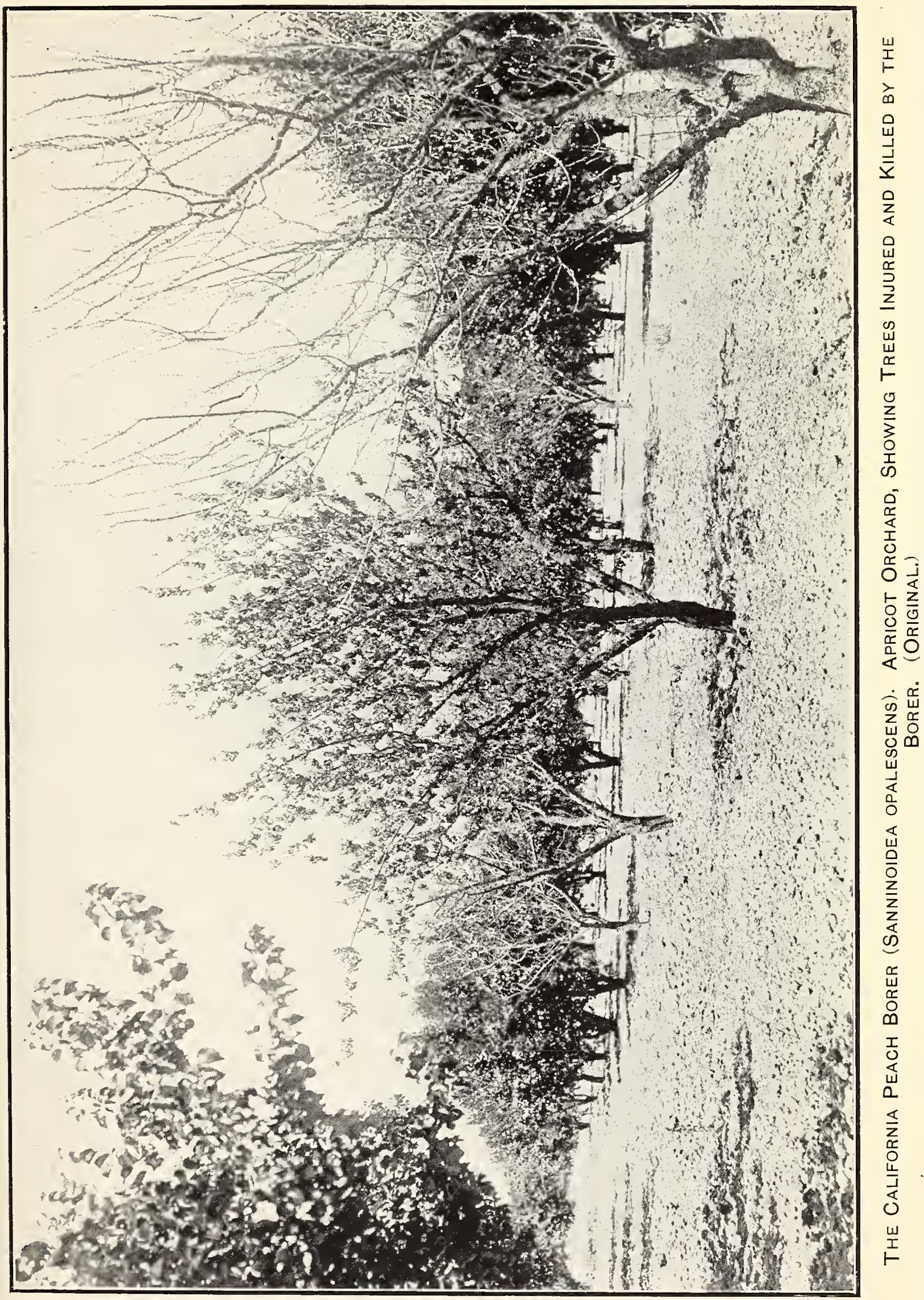



insectary, and to note the development of the eggs. (See. Pl. IX.) Oviposition under these conditions was more or less unnatural, but the eggs thus placed developed under perfectly normal conditions. The period from oviposition to the time of hatching, as indicated in Table I, lasted from 11 to 19 days, with an average of 14 days. There were several hundred eggs in each lot.

TABLE I.-Length of egg stage of the California peach borer (Sanninoidea o valescens).

\begin{tabular}{|c|c|c|c|}
\hline Lot No. & Date eggs placed. & Date eggs hatched. & $\begin{array}{c}\text { Number of } \\
\text { days. }\end{array}$ \\
\hline & July 8-9. & July $27-28$. & 19 \\
\hline & July 18. & July $31 .$. & 13 \\
\hline 3. & July 20. & Aug. 3 . & 14 \\
\hline 4. & July $21-22$. & Aug. 1-4 & 11 to 14 \\
\hline$\tilde{j}$. & ..... do .... & Llng. 3-6. & 13 to 15 \\
\hline 6. & July $23-24$. & Aug. 7. & 14 to 15 \\
\hline
\end{tabular}

In escaping, the larva breaks a circular hole through the micropye or depressed end of the egg and leaves the eggshell attached to the tree. The eggshell reinains thus attached throughout the summer and fall until early winter rains dissolve the glue by which they are attached.

FERTILITY.

Many eggs gathered from different rearing cages in our numerous experiments were noted "to determine what proportion was fertile, with the results shown in Table II.

TaBle II.-Proportion of fertile eggs of the California peach borer.

\begin{tabular}{|c|c|c|c|c|c|c|c|}
\hline Lot No. & $\begin{array}{c}\text { Fertile } \\
\text { eggs } \\
\text { hatched. }\end{array}$ & $\begin{array}{l}\text { Sterile } \\
\text { eggs not } \\
\text { hatched. }\end{array}$ & Total. & Lot No. & $\begin{array}{c}\text { Fertile } \\
\text { eggs } \\
\text { hatched. }\end{array}$ & $\begin{array}{l}\text { Sterile } \\
\text { eggs not } \\
\text { hatched. }\end{array}$ & Total. \\
\hline $\begin{array}{l}1 . . \\
2 . . \\
3 . . \\
4 .\end{array}$ & $\begin{array}{r}43 \\
42 \\
75 \\
139\end{array}$ & $\begin{array}{r}3 \\
42 \\
3 \\
15\end{array}$ & $\begin{array}{r}46 \\
85 \\
78 \\
154\end{array}$ & $\begin{array}{r}8 \ldots \ldots \\
9 \ldots \ldots \\
10 \ldots \ldots\end{array}$ & $\begin{array}{r}196 \\
55 \\
202\end{array}$ & $\begin{array}{l}3 \\
0 \\
3\end{array}$ & $\begin{array}{r}199 \\
55 \\
205\end{array}$ \\
\hline $\begin{array}{l}5 . \\
6 . \\
7 .\end{array}$ & $\begin{array}{r}71 \\
204 \\
198\end{array}$ & $\begin{array}{r}3 \\
34 \\
4\end{array}$ & $\begin{array}{r}74 \\
248 \\
198\end{array}$ & $\begin{array}{l}\text { Total. } \\
\text { Percentage. }\end{array}$ & $\begin{array}{l}1,225 \\
91.28\end{array}$ & $\begin{array}{r}116 \\
8.72\end{array}$ & $\begin{array}{r}1,342 \\
100\end{array}$ \\
\hline
\end{tabular}

THE LATIVA.

FEEDING HABITS OF NEWLY HATCHED LARVA.

The newly hatched larvæ (fig. 22, a) are extremely active and move about freely and they may crawl for a considerable distance from the egg. After hatching they immediately seek out protected places, either by hiding in cracks of the bark or under particles of dirt or loose bark, or they go below the surface of the ground and then at once begin to enter the tree.

Newly hatched larvæ were closely observed many times as they entered the bark. We were never able to watch newly hatched 
larvæ enter the bark of trees in the open field, but it was commonly observed in a laboratory experiment in which apricot branches were planted in pots of soil. The branches were about one-half inch in diameter and cut in lengths of about 12 inches, and were planted in pots or moist sandy soil. The upper cut ends of the branches were waxed over, while the lower untreated ends were embedded about 4 inches in the sand. Clusters of eggs were placed on the branches several inches above the soil, just as they would normaily be found in the field. The larvæ, which were very active, immediately sought suitable places to begin their burrows, which were sometimes started

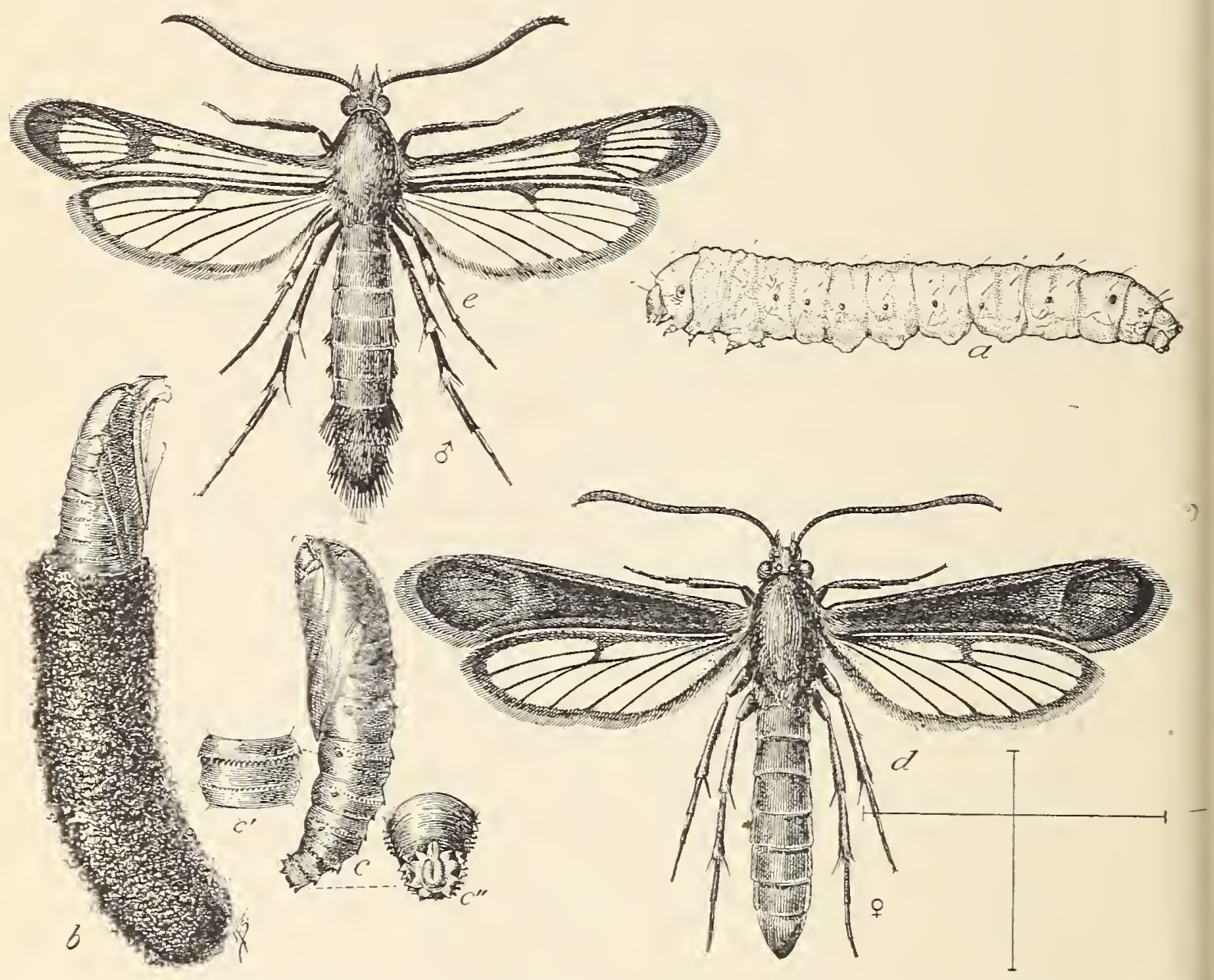

FIG. 22.-The California peach borer (Sanninoidea opalescens): $a$, Larra; $b$, cocona and pupal skin; $c$, pupa; $c^{\prime}$, abdominal segments of same; $c^{\prime \prime}$, caudal end of same; $d$, adult female; $e$, adult male. Much enlarged. (Original.)

even under the eggshells; at other times, at a considerable distance from them. Enough of their burrows were made and enough frass ejected within a couple of hours to completely corer their bodies. Always on the second dar they would be found well under the bark and to have conspicuous piles of frass above them. They entered any small cracks or irregularities of the bark or where the bark had been injured and where leaves or small twigs had been cut off. They seldom attempted to enter on a clean surface abore the ground. Most of the larvæ penetrated the surface of the soil and entered at the lower cut ends. Entering below the surface of the ground is a 
characteristic habit of the larva in the open field. Whatever the surrounding conditions they sought protected places first where they could easily penetrate to the tender inner bark. The larvæ in these experiments fed freely after a period of three weeks, when many of them were about one-eighth of an inch in length.

In the open field many larvæ enter the trees through old burrows, thus at once finding protection in the inner bark. Newly hatched larvæ have been kept in vials and fed on apricot leaves for several weeks, and they probably could have been kept much longer if fresh leaves had been properly supplied.

PERIOD WHEN ENTERING TREES.

It is seen in Table V, p. 79, that a few moths begin to fly about the 1st of June, that they are flying in maximum numbers during July and August, and that few are flying during September. Table I, p. 69, shows that the egg period lasts about two weeks, as oviposition begins immediately after the moths emerge. Consequently the larvæ begin to enter the trees during the last half of June, and they enter in maximum numbers during July and August and the first half of September. The last larvæ would be hatching and entering the trees during late September or possibly during early October.

CHARACTER OF INJURY.

Peach-tree borers usually live below the surface of the ground, but under certain conditions and on rare occasions they are to be found attacking the trunks and even the large branches. The silver prune is subject to attack in this way, and frass and the exuding gum are often found on the larger branches several feet above the ground. When a tree becomes completely girdled the worms move upward or downward into the still-living tissues, and many worms in this way may encircle and eat all of the sapwood for from 12 to 16 inches above the surface of the ground. This usually occurs during the spring, when there is a general upward movement and when the worms are preparing to pupate.

NUMBER OF BROODS AND LENGTI OF LARVAL PERIOD, AS SHOWN BY "WORMING" RECORDS.

The long period in which the larvæ are entering the trees results in a great variation in the size of the larvæ at any time of the year. This has led to the belief that there may be more than a single annual brood. Numerous worming records inclicate, however, that the insect is strictly single brooded. It often lives less than a year, but seldom longer. Larvæ that hatch in the early spring or summer change to moths early during the following season. Unfavorable conditions will delay a few, which will mature in midsummer or fall, and in this case their life period is longer than twelve months. Larvæ 
which hatch during the midsummer or in the fall usually mature during the same period of the following year. If, however, a tree has been weakened or is near to its death, the borers will invariably mature in the early spring or summer, when their life cycle will be much less than the regular twelve months.

Monthly worming records were made during a period of about two years, and although for many reasons these records can not be compared they offer much of interest. The first plan--to mark off a badly infested orchard into uniform plats and to dig all of the worms regularly from month to month on each of these plats-was not entirely satisfactory. The infestation in any orchard is extremely variable. One tree may harbor from 50 to 70 or more larvæ, while those immediately surrounding may be entirely immune. It was necessary, therefore, to find infested trees regardless of the position in the orchard when each record was made, and all worms which were collected on any one date, although they may have been gathered from many trees in various parts of the orchard, constituted the basis for the record for that particular period. Some trees would harbol 1 or 2 and other's from 50 to 70 worms. (See Pl. X, fig. 1.) The 1907-8 records were taken mostly from large apricot trees, and those for 1908-9 from apricot, prune, and peach trees.

TABLE III.--Records of larva of the California peach borer taken from trees, 1908-9.

\begin{tabular}{|c|c|c|c|c|c|c|c|c|}
\hline Date. & $\begin{array}{l}\text { Number } \\
\text { of trees } \\
\text { exam- } \\
\text { ined. }\end{array}$ & $\begin{array}{l}\text { Kind of } \\
\text { tree. }\end{array}$ & $\begin{array}{l}\text { Num- } \\
\text { ber of } \\
\text { larvæ } \\
\text { small } \\
\text { to half } \\
\text { grown. }\end{array}$ & $\begin{array}{l}\text { Num- } \\
\text { ber of } \\
\text { larra } \\
\text { half to } \\
\text { full } \\
\text { grown. }\end{array}$ & $\begin{array}{l}\text { Total } \\
\text { number } \\
\text { of } \\
\text { larræ. }\end{array}$ & $\begin{array}{l}\text { Number } \\
\text { of pupæ. }\end{array}$ & $\begin{array}{l}\text { Number } \\
\text { empty } \\
\text { pupal } \\
\text { cases. }\end{array}$ & Remarks. \\
\hline$\frac{1908 .}{\operatorname{May}}$ & & Prune... & & & Several & 0 & 0 & $\begin{array}{l}\text { Prunes on Myrobalan } \\
\text { plum root, and not } \\
\text { badly infested. }\end{array}$ \\
\hline $\begin{array}{l}15 \\
18\end{array}$ & & & & & & $\underset{2}{\text { Several }}$ & $\begin{array}{l}0 \\
0\end{array}$ & \\
\hline 23 & 19 & & 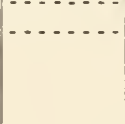 & Many & Many & 10 & 8 & $\begin{array}{l}\text { Pupæ and empty pupal } \\
\text { cases from dead trees; } \\
\text { hence very ad vanced } \\
\text { stage of insect. }\end{array}$ \\
\hline 24 & 4 & Apricot.. & 7 & 127 & 134 & 19 & 0 & $\begin{array}{l}\text { All trees completely } \\
\text { girdled; most worms } \\
\text { were nearly grown. }\end{array}$ \\
\hline 26 & 2 & ... do....... & 0 & 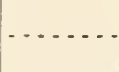 & . & 15 & 4 & $\begin{array}{l}\text { Both trees completely } \\
\text { girdled. }\end{array}$ \\
\hline June 18 & 10 & Peach. . & 8 & 33 & 41 & 0 & 0 & \\
\hline $\begin{array}{l}19 \\
20\end{array}$ & $\begin{array}{r}12 \\
3\end{array}$ & $\ldots$ do $\ldots . .$. & $\begin{array}{r}11 \\
9\end{array}$ & $\begin{array}{l}75 \\
63\end{array}$ & $\begin{array}{l}86 \\
72\end{array}$ & $1 \frac{2}{14}$ & $\begin{array}{l}0 \\
0\end{array}$ & . \\
\hline July 14 & 2 & Apricote & 2 & 1 & 3 & 23 & 17 & $\begin{array}{l}\text { Trees almost com- } \\
\text { pletely girdled. }\end{array}$ \\
\hline 20 & 2 & ...do & 0 & 12 & 12 & 10 & 47 & $\begin{array}{l}\text { Both trees completely } \\
\text { girdled. }\end{array}$ \\
\hline Nor. 5 & $\begin{array}{l}3 \\
6\end{array}$ & ...do - & $\begin{array}{r}9 \\
16\end{array}$ & $\begin{array}{l}16 \\
46\end{array}$ & $\begin{array}{l}25 \\
62\end{array}$ & $\begin{array}{l}0 \\
0\end{array}$ & $\begin{array}{l}0 \\
0\end{array}$ & $\begin{array}{l}\text { One tree contained } 8 \\
\text { larvæ, } 7 \text { of which } \\
\text { were in crotches } \\
\text { above the ground. }\end{array}$ \\
\hline Dec. $s$ & 4 & ... do. & ... & & 113 & 0 & 0 & \\
\hline $\begin{array}{ll} & 1909 . \\
\text { Jan. } & 5 \\
\text { Feb. } & 5\end{array}$ & $\begin{array}{l}5 \\
5\end{array}$ & $\begin{array}{l}\text {...do. } \\
\text {... do. }\end{array}$ & 76 & 13 & $\begin{array}{l}67 \\
89\end{array}$ & $\begin{array}{l}0 \\
1\end{array}$ & $\begin{array}{l}0 \\
0\end{array}$ & $\begin{array}{l}\text { Larvæ were of all sizes. } \\
\text { Larræ in this record } \\
\text { mostly Small; one } \\
\text { larra in newly } \\
\text { formed cocoon. }\end{array}$ \\
\hline
\end{tabular}


TABLE III.-Records of larvæ of the California peach borer taken from trees, 1908-9Continued.

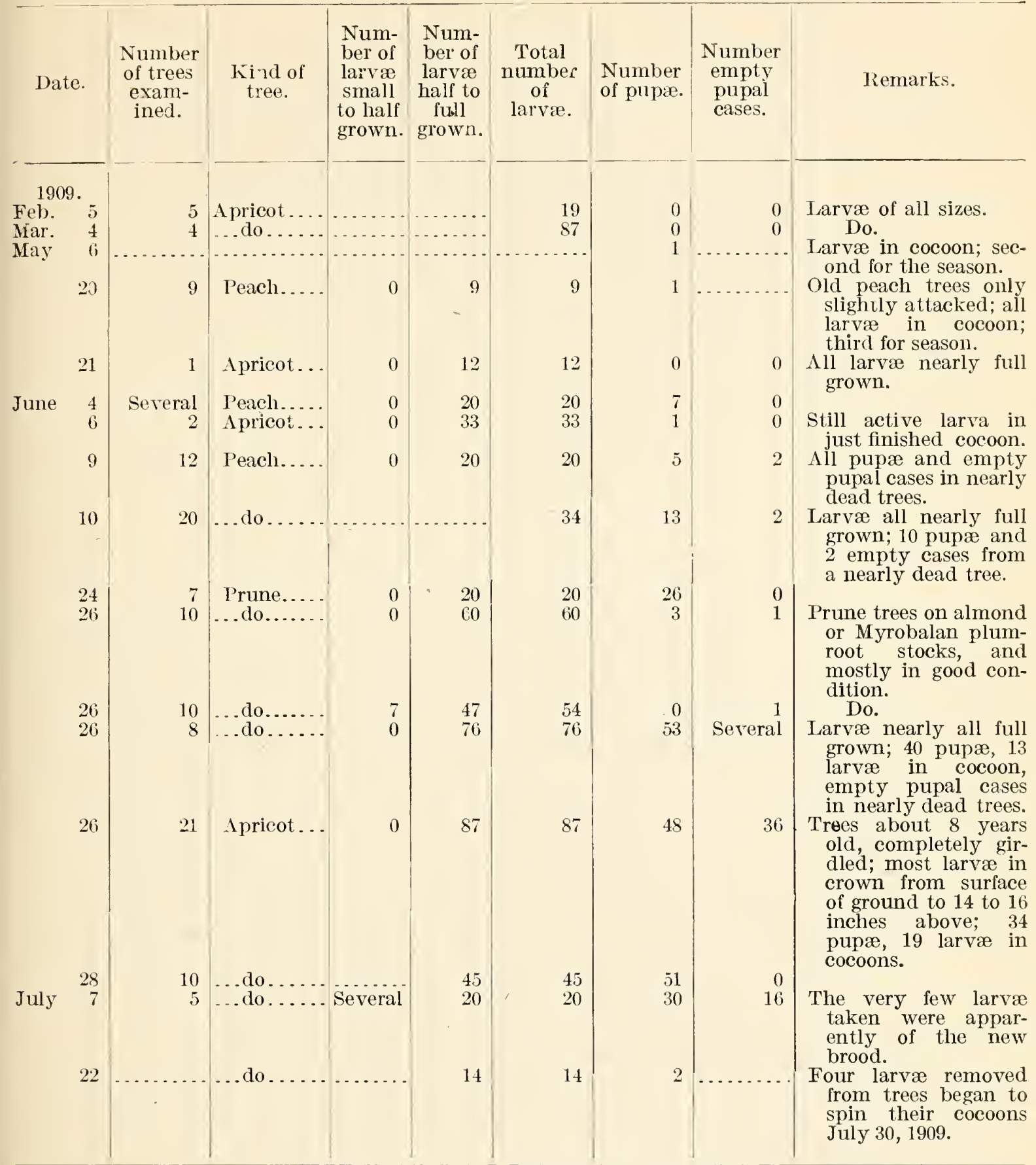

The worming records, so far as they are related to the larval stages, may be summed up as follows:

Newly hatched and very small larvæ were found from early in June to October and November. Half-grown larvæ can be found at any time during the year. Larvæ which are fully grown during the summer usually transform to moths during late summer or fall, while larvæ which are full grown during the fall and winter transform to moths early during the following spring. Larvæ more than half grown to full grown are most numerous during the winter and spring. Larvæ are apparently active throughout the winter and are never entirely dormant. 
FEEDING HABITS WITHIN THE BURROW.

There is no regular method of forming a burrow. After the borers have penetrated into the cambium layers, they may move upward or downward or to the side. The burrow may be long and narrow or short and broadened. The larva moves about in its burrow at will and cleans out the frass and exuding gum and ejects it through the outer opening and because of this the opening often becomes a more or less conspicuous tube of such castings. The castings and exuding gum are quite conspicuous and always indicate the presence of worms and show where the burrows are. Where many worms completely girdle a tree there are no individual burrows, and the worms may then be feeding closely together.

THE PUPA.

(Fig. 22, b, c.)

FORMATION, STRUCTURE, AND POSITION OF COCOON.

The mature larva selects a place to form its cocoon near some kind of an opening where the adult moth can readily escape. This may be near the entrance to the burrow, or near a break in the bark, or if under unbroken bark the worm may eat out a small round exit hole before it goes into the cocoon. Larvæ which are located in the larger roots pupate in the usual way if these roots are near the surface. On May 26, 1908, during the process of worming 6 pupæ were dug out from a root and in this case they were 12 to 15 inches away from the trunk of the tree. Larvæ often move out from the lower roots and also occasionally leave the tree trunk and pupate a few inches below the surface and in the open soil several inches away. On one occasion 7 empty cocoons were found from 1 to 5 inches away from the tree and from 1 to 3 or 4 inches below the surface. Occasionally pupæ may be found 2 feet or more above the ground in the lower branches. On June 10, 1907, 2 pupæ were found in the sunburned area on a large branch, several feet above the ground.

The cocoon is constructed of chewed particles of bark and wood, excreta, and gum, and bound together by a silken web and lined inside with silk. The completed cocoon is exceedingly tough and strong and rather rigid. The anterior end alone is thin and weak and offers only a little resistance when the mature pupa begins to force its way out. Cocoons which are located in the soil are made of particles of earth, but they, like others, are held together and lined with silken threads. The cocoon is elongate oval in shape and about an inch in length. Female cocoons are larger than those of males, although they, too, are sometimes abnormally small when 
they are found in a tree which has been completely girdled and dies prematurely.

A cocoon may be placed with its anterior end directed upward, sideways, or downward, and it usually has a clearly open space in front, so that the pupa will not be hampered in getting out and so that the issuing moth will also find an easy exit. Of 26 empty pupal cases collected on July 20, 1908, from a completely girdled dead tree, 15 were so placed that the emerging moths could escape directly to the open air, but 11 were found under the large expanse of dead bark and could get out only through rather distant openings.

\section{DESCRIPTION OF PUPA.}

The late Prof. Slingerland, in his bulletin on the eastern peachtree borer, states that the male pupa can be readily distinguished from the female by its more slender shape and smaller size and by the double row of spines across the seventh abdominal segment, which bears the last or caudal spiracles. These same sexual differences are also clearly characteristic of the western borer.

The pupa is normally dark-brown in color. It is, however, very light brown when first formed and almost black-brown just before the moth issues. The beaklike anterior tip is strong and sharp and easily cuts through the weak anterior end of the cocoon. In leaving the cocoon the mature pupa hitches itself forward by means of the numerous backwardly directed dorsal spines and forces itself about half way out from the cocoon, and immediately the shell splits along the dorsal side and the moth issues. The posterior end of the pupa remains fastened to the cocoon for an indefinite period after the moth has gone.

LENGTH OF PUPAL PERIOD.

The individual pupation record given in Table IV indicates clearly the length of time required in the several changes during the process of pupation. 
TABLE IV.-Individual pupation records of the California peach borer.

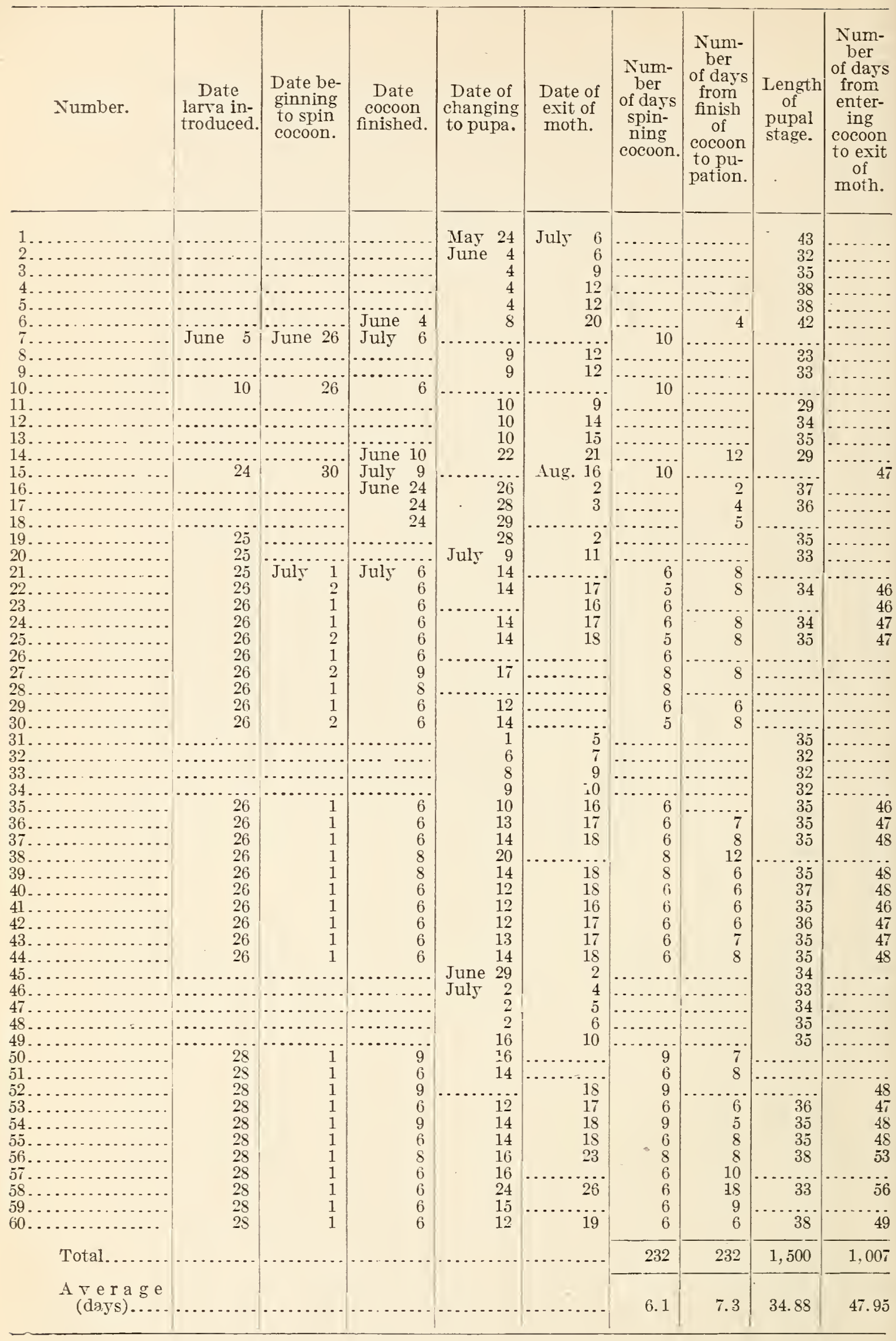


The process of spinning the cocoon, as above indicated, occupies about 7 days, and there then follows another period of about a week before pupation is apparent. The larva is inactive during this second period, but wakes up immediately if disturbed or if it is torn from the cocoon. The larva has strength to spin a second cocoon, but in doing so becomes so weakened that it seldom if ever transforms to a moth. The pupal stage occupies a period of about 35 days. The insect is actually in the cocoon from 46 to 56 days.

EARLIEST, MAXIMUM, AND LATEST APPEARANCES OF PUPA.

During the season of 1908 the first pupa of the season was found on April 29, but at this time most larvæ were still active and not ready to change to pupæ. On May 15 several cocoons were found which contained quiescent larvæ, but none of them contained pupæ. No empty cocoons had been observed up to this time. Numerous pupæ found on May 23, 24, and 26 indicated that the period of pupation had begun.

Four recently killed trees were examined on May 23 and 26, and besides numerous pupæ 12 empty pupal cases were found. These trees had been completely girdled by numerous borers and had died early in the spring, so that a lack of food had caused the borers to hasten through to maturity. These cases were the first for the year and they indicated that this was the beginning of the period when moths were flying. All of these early individuals which were found in dead trees were undersized and the males were about as large as the females.

During the season of 1909 one quiescent larva in a cocoon was found on February 5 and the first pupa on May 6. On May 19 a second pupa was found. One empty pupal case, the first of the season, was found on the same day; this, again, indicated that the time for flight of the moths was beginning.

Pupæ and empty pupal cases were found frequently during all the summer, but pupæ were found in maximum numbers during June, July, and August. The first or earliest empty pupal cases were always collected from trees that were dead or nearly dead and the cases were usually undersized. The later maturing individuals were always found on healthy trees.

\section{THE ADULT.}

(Fig. 27, d,e.)

HABITS OF NEWLY EMERGED MOTHS.

When a moth has just emerged its wings are soft blackish pads and lie on the surface of the back, but immediately they begin to open. out and after 10 or 15 minutes are fully expanded. The moths 
are active and jump about in an erratic way and at first are aided only slightly by the partly developed wings. As the wings expand the moth rests for a few minutes until the wing tissues are set, and it then immediately flies away. Newly emerged moths, when confined in rearing cages or jars, buzz and throw themselves against the sides of the cage with comparatively great force.

ORIGINAL DESCRIPTION AND SUBSEQUENT NOTES.

Henry Edwards in 1881 described the adult of the peach-tree borer under the name Egeria opalescens. ${ }^{1}$ The description is as follows:

Steel blue, the fore wings with the opaque spaces greenish black, the vitreous spaces very opalescent, with a few silvery scales, hind wings with bright opalescent reflection. Fringes of both wings purplish black. Beneath the silvery scales of fore wings are much more numerous, extending over the whole vitreous surface. Head, palpi, and antennæ, deep jet black. Thorax concolorous with fore wings. Abdomen, dark steel blue. The whole of the under surface greenish black, the tibiæ having at their base a tuft of whitish hairs. Spurs whitish, speckled with black.

Exp. wings $28 \mathrm{~mm}$.

3 males, Virginia City, Nevada. (H. E.)

1 female, Colorado (Morrison).

Type: Coll. Hy. Edwards.

Later, Beutenmüller, in his Monograph of the Sesiidæ, changed the name of the insect to Sanninoidea opalescens, ${ }^{2}$ and gave the following notes on its description.

Male.-Head, thorax, and abdomen entirely black. Legs black with white tufts. Fore wings transparent with black margins. Transverse mark and outer margin very broad. Hind wings transparent with black border. Underside of wings same as above.

Female.-Head, thorax, abdomen, and legs wholly bronzy black, forewing opaque, bright metallic green black. Hind wings transparent, opalescent, outer margin and fringe blue, or green black. Underside same as above.

Expanse: Male 25-30 $\mathrm{mm}$; female 30-34 $\mathrm{mm}$.

Habitat: Nevada, California, Washington, Oregon.

Types: Two māles. Coll. Hy. Edwards, Am. Mus. Nat. Hist. Male and female S. pacifica. Coll. U. S. Nat. Mus.

Beutenmüller also adds that Sanninoidea opalescens differs Irom the eastern peach borer, Sanninoidea exitiosa,

By having the transverse mark and outer margins of the fore wings of the male much broader. In the female the fore wings are opaque, the hind wings transparent and the abdomen wholly blue or green black.

The striking difference between the two species, however, is that the upper part of segment 4 in the females of Sanninoidea exitiosa is orange colored, while the dorsal segments in Sanninoidea opalescens are uniformly steel blue-black.

\footnotetext{
1 Papilio, vol. 1, no. 10, p. 199, 1881.

${ }_{2}$ Monograph of the Sesiidæ of America, North of Mexico, vol. 1, Part VI, Mem. Amer. Mus. Nat. Hist.s p. $271,1896$.
} 
EARLIEST, MAXIMUM, AND LATEST APPEARANCES OF MOTHS.

The first moth during the season of 1908 was found resting on an apricot leaf near the crotch of a tree on April 16, and on May 15 another was seen in a similar position. On these same days two or three empty cocoons were found, which indicated that other moths had also emerged. The data in Tabie $\mathrm{V}$ indicate the period when moths are flying.

TABLE Y.-Records of emergence of moths of the California peach borer, 1908-9.

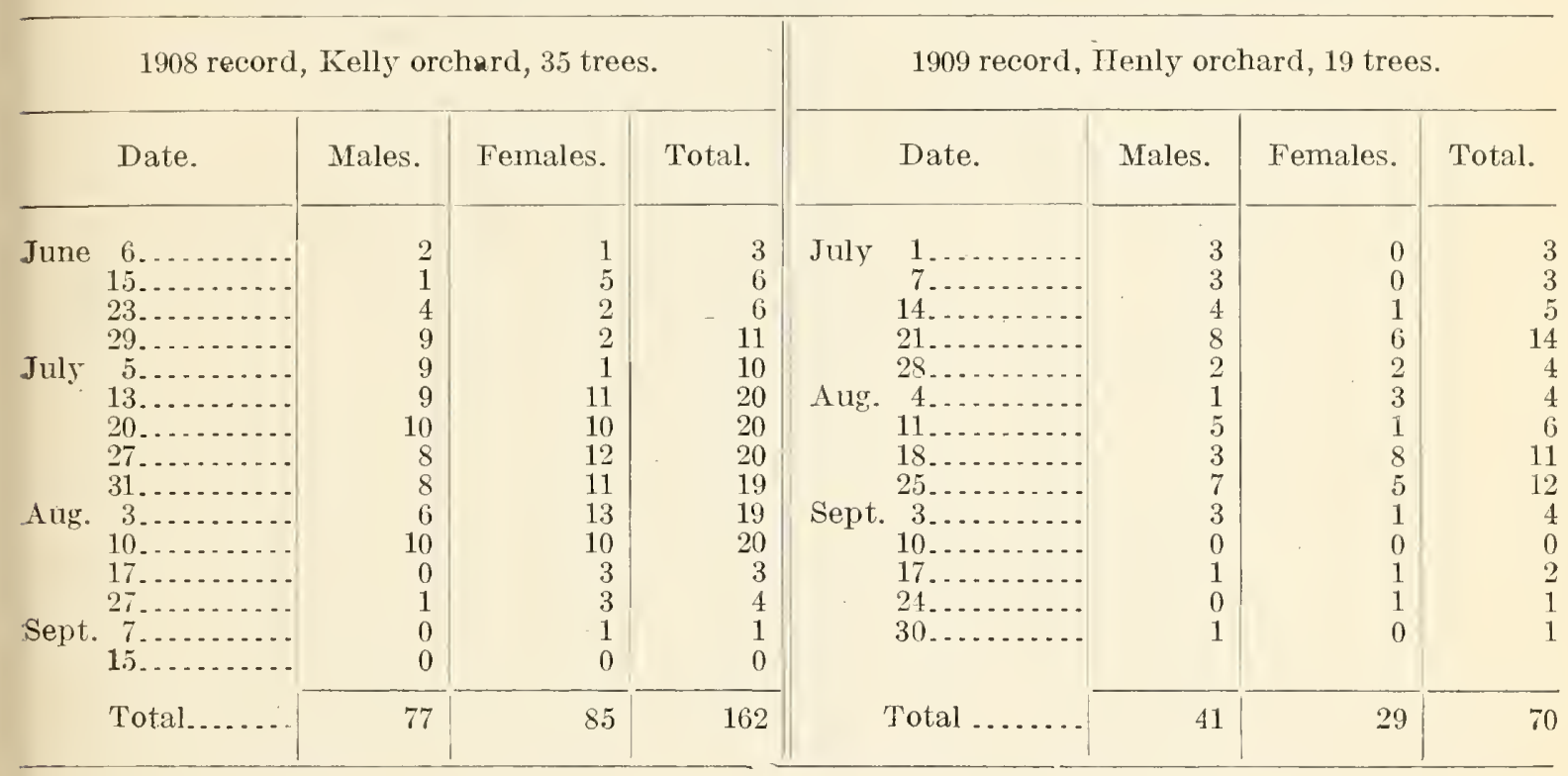

These records of emergence of moths for the two seasons of 1908 and 1909, respectively, were taken from series of wire-mesh traps (Pl. X, fig. 2), which were placed around the lower trunks of apricot trees. During the season of 1908 the records were made in an uncultivated orchard about 3 miles from San Jose. Thirty-five wire cages were placed around as many trees, and the moths which emerged were collected at regular intervals of a week, except that they were collected every two or three days during the period of maximum emergence. The records for the season of 1909 represent moths collected from the cages which had been placed around apricot trees in another orchard.

A perusal of the table indicates that an average of 5 moths emerged from each of the 35 traps during the season of 1908. An average of 8 moths per tree and a maximum of 27 moths from a single tree were recorded during the season of 1909. The record of 1908 shows an emergence of more females than males, and the records of the following year just the opposite. This fact probably has no special significance, since the totals in either case are not sufficiently large to be of value in determining the relative number of either sex. A few moths are thus to be seen flying in April and May and many more during July and the first half of August. A few late individuals appeared during September. 
FLIGHT, FEEDING, AND MATING.

The moths for the most part fly within a few feet of the ground and move in an erratic way, dashing from place to place or from tree to tree. Individuals flying into or over the tops of large trees are only rarely seen. Males are often found buzzing and hovering around trap cages in which females are confined. Both sexes are extremely active and hard to catch. Moths are often seen resting on leaves or on trunks of trees.

Moths have never been observed in the act of feeding. Drops of sweetened liquids and honey were placed on apricot leares in the trap cages, but the moths were never seen even sipping at this.

Mating occurs as soon after the moths have emerged as the male and female c̀an come together. Individuals from separate rearing jars only a few minutes after issuing from their cocoons were observed to copulate as soon as they were placed together in the same rearing cage. In one instance a male which was known to have mated a few hours previously was placed in a cage with a newly issued unimpregnated female. Both alighted on the ground and copulation took place immediately-so quickly, in fact, that one could not follow the movements. The individuals remained in copulation 1 hour and 20 minutes. The previous copulation of this male had lasted 1 hour and 17 minutes. Other matings have been observed to last as long as 1 hour and 30 minutes. Copulation was observed many times.

\section{OTIPOSITION.}

Female moths begin to place their eggs within a few hours after emerging from the cocoons. They have been observed in rearing cages to mate during the forenoon and to place eggs in the afternoon-never later than the following day. Within two or three days oviposition is completed and the moths die.

The rearing cages for the life-history study of the insect were about 2 feet square and 6 feet high, with wire-mesh cloth on all sides. They were placed over small apricot trees which had been planted for this purpcse in the back yard of the insectary. (See Pl. IX.) The moths thus introduced were out of doors, could fly and mate under almost normal conditions, and it was found that oriposition and egg derelopment could be watched easily.

Within the rearing cages the moths placed their eggs at random, on the small trunks, stems, and leaves of the trees, and eren on the inside of the cages. Most of the eggs, however, were placed on the underside of the leares. A moth would fly to a branch and rest on it for a few minutes, and after placing a few eggs would quickly fly away and soon repeat the operation. Eggs were placed sometimes singly, but mostly in groups of from 2 or 3 to 25 or 30 or more. A moth was observed to alight on a leaf, place 2 eggs in about 10 seconds, and then fly away. 


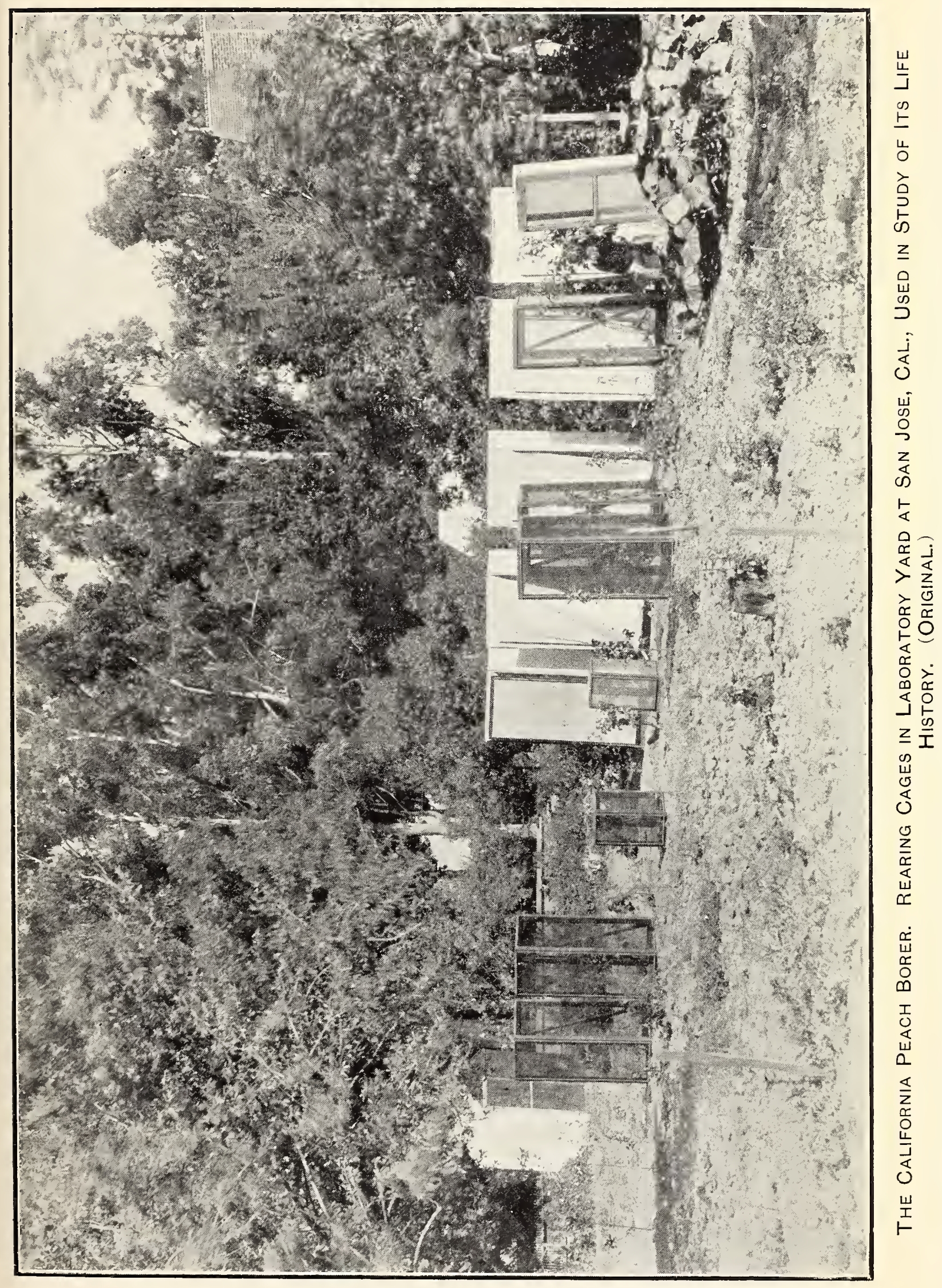




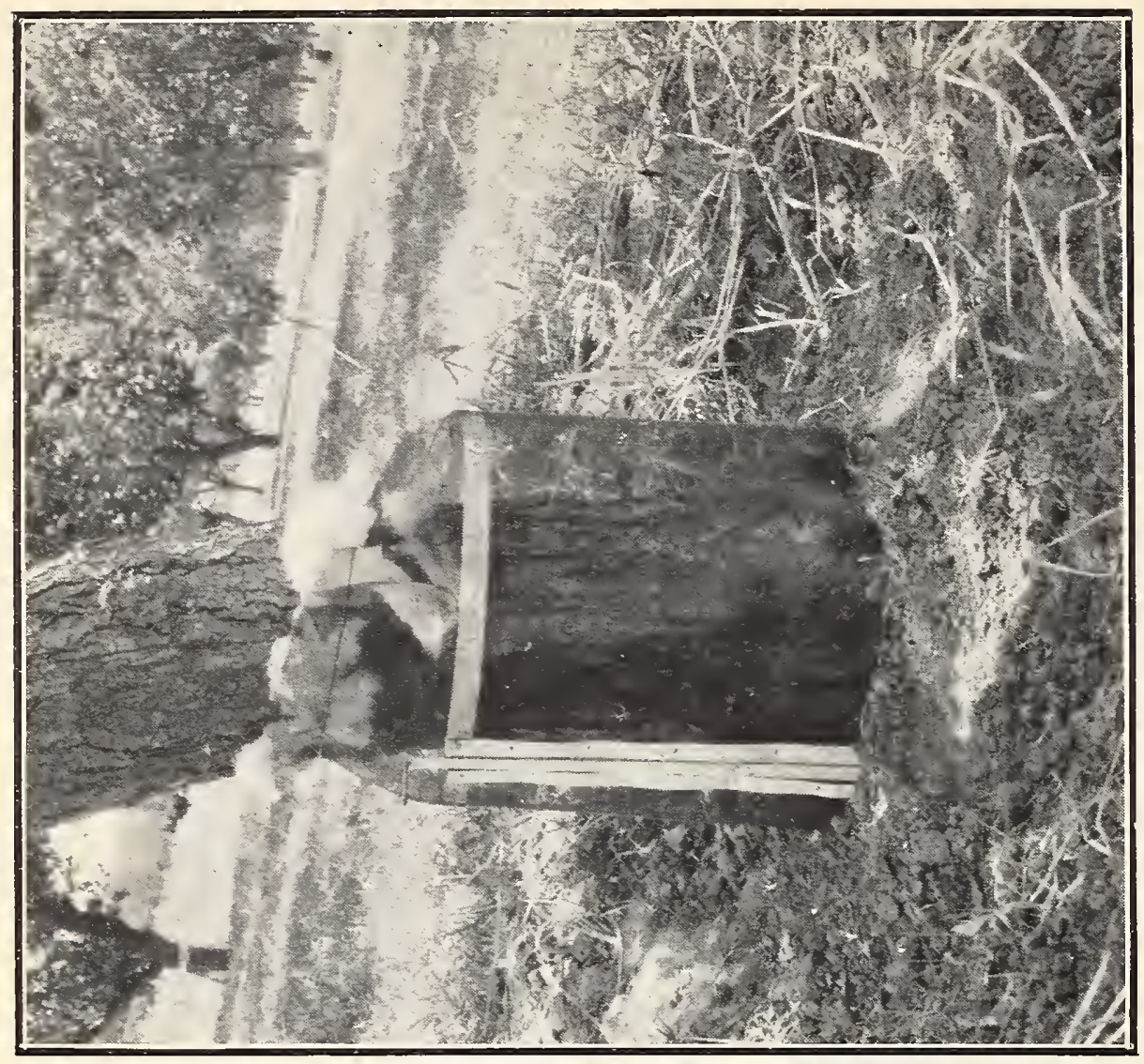

แั้ํำ

은 둔

징

는

잉

$\frac{z}{z} \frac{\pi}{4}$

$\sum$ 닌

$\sum_{0} 0$

岃

㟧 $z$

$\underline{z}$

동

岁占

$\supset \Sigma$

嵌㟔

ड

ن

峛安

$\sum_{\substack{1 \\ 0}} \frac{z}{\mathrm{~N}}$

i $\sum_{i=1}^{\infty}$

N

$\frac{0}{4}$

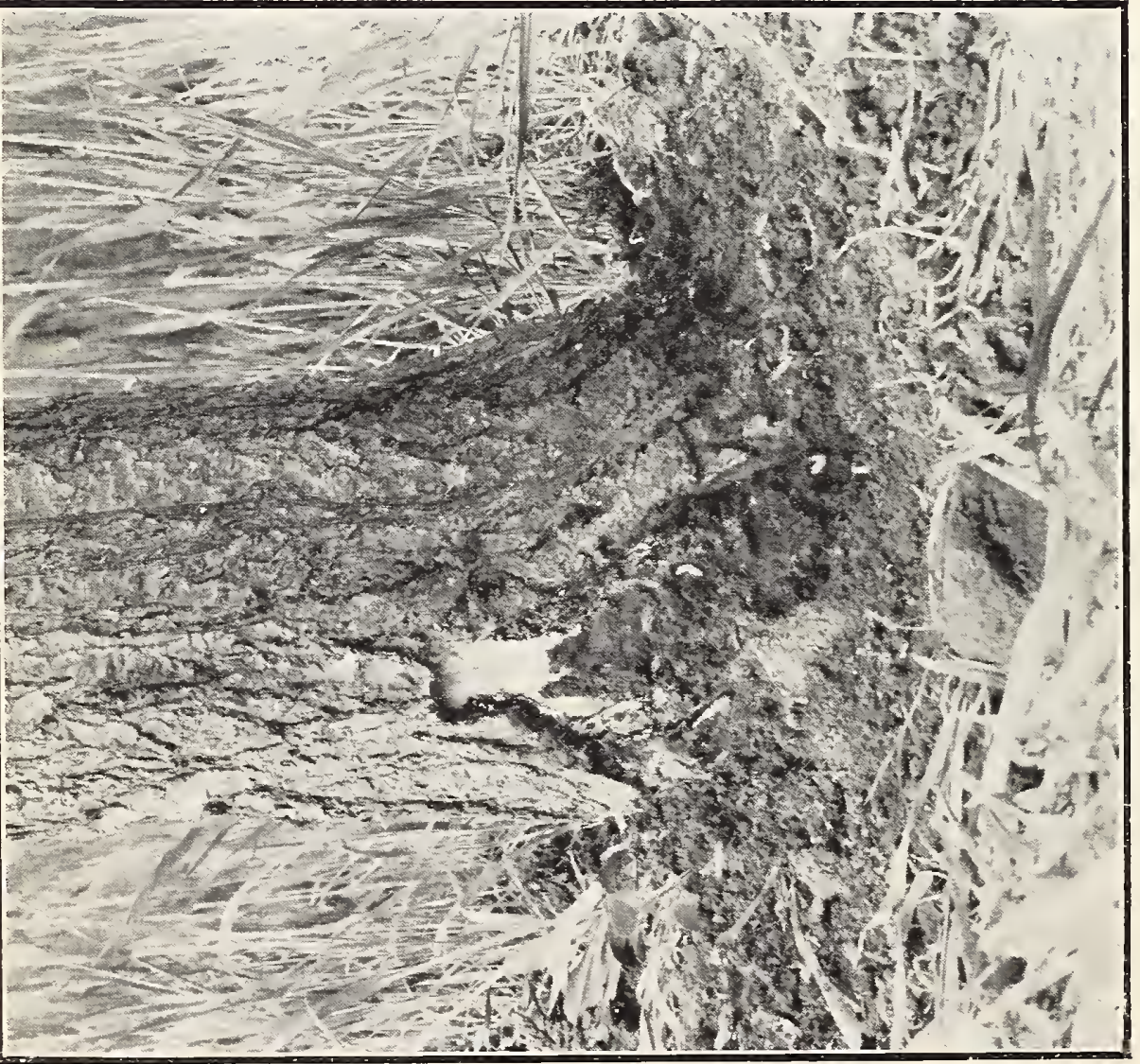

$\frac{\widetilde{v}}{\frac{\pi}{\alpha}}$ 
Numerous records of oviposition by moths which were confined in cages indicate that the favorite place is on the lower surface of the leaves (Table VI).

TABLE VI.-Oviposition of moths of the California peach borer within the rearing cages.

\begin{tabular}{|c|c|c|c|c|c|}
\hline Cage No. & $\begin{array}{l}\text { Eggs } \\
\text { placed on } \\
\text { wood of } \\
\text { cage. }\end{array}$ & $\begin{array}{l}\text { On } \\
\text { branches. }\end{array}$ & $\begin{array}{c}\text { On } \\
\text { upper } \\
\text { surface } \\
\text { of leaves. }\end{array}$ & $\begin{array}{c}\text { On } \\
\text { lower } \\
\text { surfaces. }\end{array}$ & Total. \\
\hline $\begin{array}{l}3 \ldots . . \\
5 \ldots \ldots \\
6 \ldots \ldots\end{array}$ & $\ldots$ & $\begin{array}{c}16 \\
66 \\
20 \\
20 \\
66\end{array}$ & $\begin{array}{r}14 \\
49 \\
272 \\
144 \\
48\end{array}$ & $\begin{array}{r}119 \\
53 \\
474 \\
40 \\
220 \\
102\end{array}$ & $\begin{array}{l}204 \\
168 \\
746 \\
204 \\
268 \\
223\end{array}$ \\
\hline Total.. & 110 & 168 & 527 & 1,008 & 1,813 \\
\hline
\end{tabular}

Moths flying in the open field always place their eggs on the lower trunk a few inches above the surface of the ground. The eggs are arranged in groups as in the rearing cages. A careful examination of branches and leaves of several trees in a badly infested orchard showed no eggs elsewhere than on the lower trunk, but many groups of eggrs were found on individual trees. A moth was once observed to fly and alight on the trunk of an apricot tree about 5 inches from the ground. She soon moved 2 or 3 inches higher and remained there about two minutes, placing about 12 eggs; she then flew rapidly away until she was lost to sight. Thirty other eggs which had been placed at some previous time were also observed near this group. All were within a radius of 2 inches and were grouped in numbers of from 3 to 10. They were not definitely arranged. Clusters of eggs can be found easily on the lower trunks of trees in any badly infested orchard.

The eggs on a single five-year-old apricot tree in the open field (Kelly orchard) were numbered and grouped as follows: $2,3,3,6,8$, $8,9,10,27$, and there were about a dozen scattered, singly-placed eggs. All were between 1 and 2 inches above the surface of the ground. On a second tree 44 eggs, all near the surface, were grouped as follows: $1,1,1,2,2,2,2,4,6,8,13$. All the eggs on both these trees were hatched when examined (Aug. 10, 1908).

Records of oviposition by individual moths may be listed as follows: 294, 275, 205 (6+199 dissected), and 412. Eight unmated females which were placed in confinement oviposited as follows: 5, 6 , $11,11,25,43,50,83$, and in each case the moth died before the second day.

Table VII, which is a record of oviposition by individual moths, indicates how soon oviposition begins after mating, how long it continues, the number of eggs placed, and the life of the moth. All moths were introduced into the individual cages immediately after they were taken from the trap cages in the field. 
TABLE VII.-Lating and oriposition of the California peach borer.

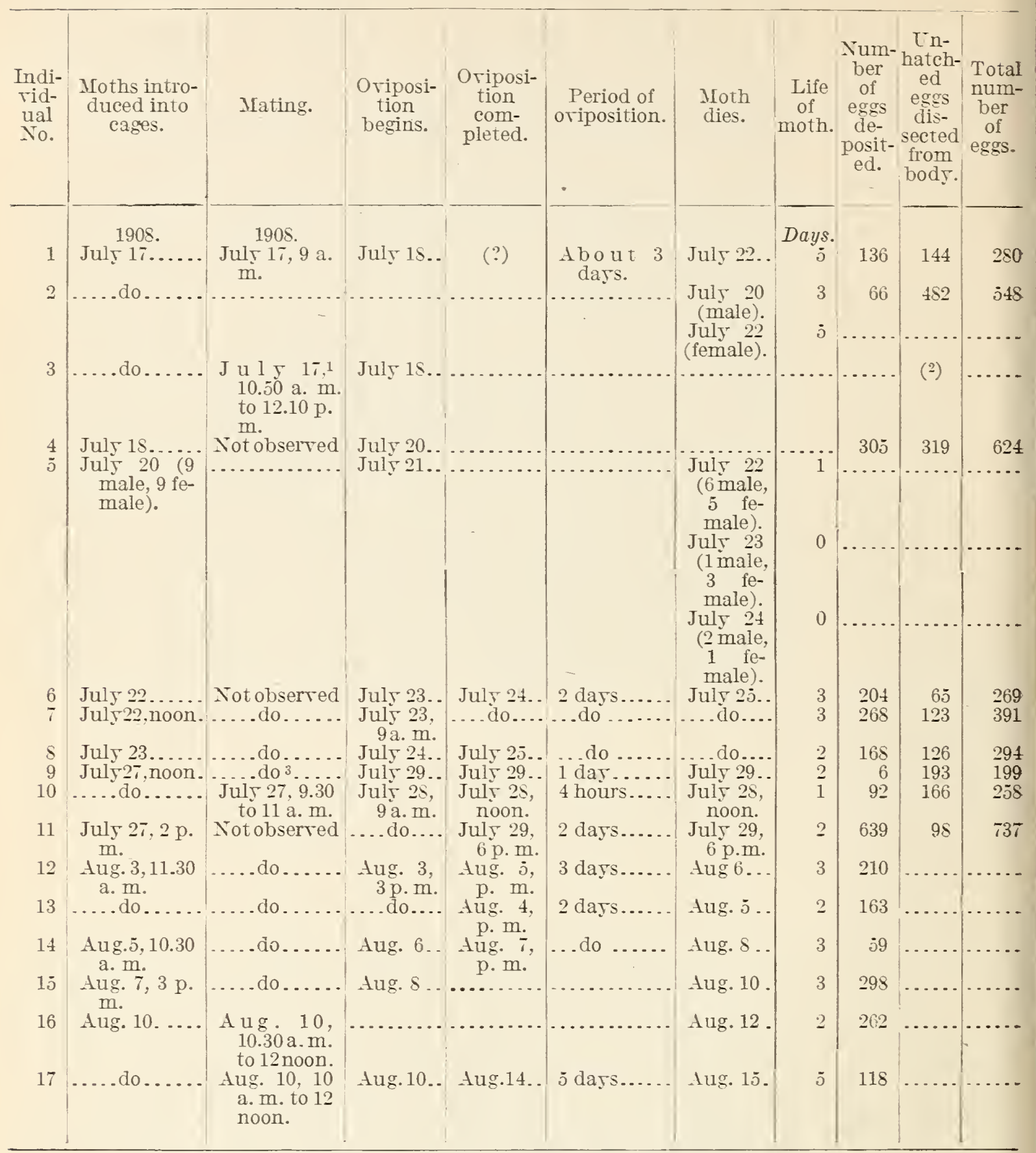

1 Wale had mated previously with another female for 1 hour and 17 minutes.

2 Manr eggs laid, but none hatched.

3 Male had mated preriously.

Table VII indicates that moths began oviposition a few hours after issuance, or at the latest on the following day. The period of oviposition of a single moth is seldom longer than two or three days, and the moths die immediately thereafter:

LENGTH OF LIFE OF THE MOTHS.

Moths which were kept from mating were found to die without having placed any or at least only a few eggs. Female moths die immediately after oriposition is completed. Males die soon after mating. Oviposition within the rearing cages would begin within a few hours ( 8 to 10) after mating, and always within 24 hours; it would be completed within 3 or 4 days and none was observed to live longer than 5 days. 


\section{NATURAL ENEMIES.}

There is a species of ant which has been observed many times to attack adult moths, pulling them to pieces and literally eating them alive. It often happened that a moth would become entangled in the creases of the wire mesh or in the cotton of our trap cages where the traps were bound around the tree. Almost invariably their bodies would soon be torn to pieces by these ants. The ants presumably are not of economic importance in controlling the moth of the borer.

On another occasion a nest of small white mites was taken from the body of a dead moth, as well as a dipterous larva.

\section{METHODS OF CONTROL.}

\section{EXPERIMENTS WITH PREVENTIVES.}

Six large apricot trees in the insectary yard were treated as follows: The dirt was first dug away from the lower trunks to a depth of 8 or 10 inches, the bark was scraped, the few worms present were removed, and the lime-oil wash was applied over the newly exposed bark and to a height of 16 or 18 inches above the ground. The mixture was swabbed on thickly with a large calcimining brush and was applied on June 25, 1908.

On August 4, 1908, six weeks later, numerous clusters of eggs just ready to hatch were selected from the rearing cages and attached to the treated trees at a height of from about 5 to 10 inches above the ground, where they would normally be placed on untreated trees in the open field. This experiment was made under extremely unnatural conditions, because eggs are apparently never placed directly on any treated surface. It served our purpose, however, which was to determine the number of young that could really penetrate through the wash and get into the tree. The wash was still in a good condition on August 4, when the eggs were attached. Table VIII gives the details of the experiment and the results of examination of trees September 21.

TABle VIII.-Details of experiment No. 1 with protective lime-oil wash against the California peach borer.

\begin{tabular}{|c|c|c|c|c|c|}
\hline Tree No. & $\begin{array}{l}\text { Number } \\
\text { of eggs } \\
\text { placed } \\
\text { on tree. }\end{array}$ & Position of eggs on tree. & $\begin{array}{l}\text { Number } \\
\text { of eggs } \\
\text { hatched. }\end{array}$ & $\begin{array}{c}\text { Date of } \\
\text { hatch- } \\
\text { ing. }\end{array}$ & Remarks. \\
\hline 1 & 46 & 5 inches above ground on north side & 43 & Aug. 12 & \multirow{5}{*}{$\begin{array}{l}\text { No sign of borers found. } \\
\text { Do. } \\
3 \text { empty pupal cases } \\
\text { found. } \\
\text { No sign of borers. } \\
3 \text { empty pupal cases. } \\
\text { No sign of borers. } \\
6 \text { moths matured. }\end{array}$} \\
\hline$\frac{2}{3}$ & $\begin{array}{l}85 \\
78\end{array}$ & do & $\begin{array}{l}42 \\
75\end{array}$ & $\begin{array}{l}\ldots \text { do } \ldots . . . \\
\ldots \text { do } \ldots . .\end{array}$ & \\
\hline \multirow{3}{*}{4} & 154 & & 139 & Aug. 25 & \\
\hline & $\begin{array}{r}74 \\
248\end{array}$ & $\begin{array}{l}2 \text { inches above ground. } \\
\text { On lower trunk. }\end{array}$ & $\begin{array}{r}71 \\
210\end{array}$ & Aug. 26 & \\
\hline & 685 & Total. & 580 & & \\
\hline
\end{tabular}


Table VIII indicates that a total of 580 , or about 80 per cent, of the 685 eggs hatched, but only 6 worms (about 1 per cent) were able to penetrate through the lime-oil wash, enter the trees, and finally mature to moths. Formel experiments (see Table II) show a higher percentage of fertile eggs. A great discrepancy between the number of eggs which hatch and the worms which actually are able to enter the trees had been previously noticed. There is also a great mortality of larvæ, as is evidenced by the number of worms which may be found in any tree and the number of moths that may mature later. The almost complete immunity of these trees is not, therefore, attributed entirely to the effectiveness of the lime-oil wash.

Experiment No. 2.-The Wilson experiment was planned to determine the danger of injury by applymg crude oils directly and in combination with lime to peach trees and also to determine the value of these oils as repellents or barriers against the entrance of borers. Crude oils have been applied directly to various fruit trees by orchardists in the Santa Clara Talley, and their application has proved fairly successful. Occasional injury has been reported. Peach and apricot, and especially the younger trees of these varieties, are very sensitive to oil, and it is believed that there must be more or less injury to other trees. The crude oil is undoubtedly a most effective barrier to keep newly hatched worms from entering the trees, and it also penetrates and draws many more mature worms out to their death. The oils, therefore, have a distinct and decided insecticidal effect against the borers.

The Wilson experiment was arranged in three plats-Plat I, with 10 trees (numbered 1 to 10 , inclusive), Plat II, with 5 (numbered 11 to 15 ), and Plat III, with 10 (numbered 16 to 25 ). The earth was removed, the borers dug out, and the bark scraped, as in experiment No. 1. The various remedies were applied on June 20, 1908.

Plat I was treated with the lime-oil mixture, which is recommended as formula No. 1. It was applied just as it was used in the previous experiment. Three gallons of the mixture were sufficient to treat the 10 trees.

Plat II was treated with a ight grade of pure crude oil known as Coalinga crude oil, $22^{\circ}$ Baumé. This was likewise applied with a large brush and in similar way to the lime-oil mixture. One gallon was sufficient to treat these five trees.

Plat III was treated with a heavier grade of oil known as Kern crude oil, or about 14 to $16^{\circ}$ Baumé. This oil was cold and heavy and rather hard to applr. Three gallons were sufficient to treat the 10 trees.

The earth was immediately replaced around all of the trees after the treatment. 
The trees were examined from time to time, and injury from the oils was soon apparent. Early in October most of the leaves on the trees in plats Nos. 2 and 3 had fallen, and the remainder of the leaves were curled and nearly ready to drop. There was a marked contrast between the oil-treated trees and those which were treated with the lime-oil wash or which were not treated at all. Trees treated with the lime-oil wash were apparently in normal condition. The oiltreated trees again in the spring of the following year were in a weakened condition, and by June 1 trees No. 13 in Plat II and 23 and 25 in Plat III were dead. All trees in Plat $I$ and the adjoining check trees were in normal condition and possessed a bright, healthy, green foliage. It is very evident that peach trees can not be safely treated with crude oil alone, although the lime-oil combination appears altogether safe. The trees in this experiment were examined from time to time to notice any new infestation of the insects, and no worms or pupæ or pupal cases were ever found on any of the treated trees, although numerous worms infested the surrounding check trees.

In addition to the attack which would normally be made by moths living in the open field, several trees were subjected to attack by placing fertile eggs on them as in experiment No. 1. Table IX shows the number of the eggs, where they were placed, and the results of examination of trees June 10, 1909.

TABLE IX.-Details of experiment No. 2 with protective washes against the California peach borer.

\begin{tabular}{|c|c|c|c|c|c|c|}
\hline $\begin{array}{l}\text { Plat } \\
\text { No. }\end{array}$ & $\begin{array}{l}\text { Tree } \\
\text { No. }\end{array}$ & $\begin{array}{l}\text { Number } \\
\text { of eggs. }\end{array}$ & $\begin{array}{l}\text { Number } \\
\text { hatched. }\end{array}$ & $\begin{array}{l}\text { Date of } \\
\text { hatching. }\end{array}$ & $\begin{array}{l}\text { Num- } \\
\text { ber ma- } \\
\text { tured. }\end{array}$ & Remarks. \\
\hline $\begin{array}{l}\text { I. . . } \\
\text { III. } \\
\text { III. }\end{array}$ & $\begin{array}{r}6 \\
8 \\
11 \\
22\end{array}$ & $\begin{array}{r}163 \\
41 \\
144 \\
225\end{array}$ & $\begin{array}{r}150 ? \\
34 \\
136 \\
216\end{array}$ & $\begin{array}{l}\text { 1908 } \\
\text { Aug. } 17 \\
\text { Aug. } 12 \\
\text { dug. } 13\end{array}$ & $\begin{array}{l}\text { None. } \\
\text { None. } \\
\text { None. }\end{array}$ & \multirow[t]{2}{*}{$\begin{array}{l}\text { No larvæ, pupæ, or pupal cases taken from } \\
\text { any of the treated trees, although infestation } \\
\text { was common in adjoining cheek trees. }\end{array}$} \\
\hline Total. & & 573 & 536 & & None. & \\
\hline
\end{tabular}

"WORMING" AND APPLYING WASHES IN THE SANTA CLARA VALLEY.

The method of controlling the borer as practiced by orchardists in the Santa Clara Valley is to "worm" the trees by hand during the winter or spring months and later apply a protective wash before the dirt is thrown back. Some orchardists, however, dig the borers out without giving any subsequent treatment. The digging out process is the most important and most effective. 'The earth is shoveled away from the crown of the tree, the dirt and old bark scalings are scraped off, and the worms are cut out by hand. An ordinary three-fourths-inch wood chisel and a horseshoe knife are 
now conceded to be the best tools in use. A combined scraper, chisel, and rounded worming blade has been used extensirely, but tools of this kind do not contain the fine quality of steel that is found in other knives and chisels and they soon become dull. The bark is often broken rather than cut when such tools are used, and this works serious injury to the tree. The curred worming blade is especially harmful, because it is forced into the burrow and great pieces of living as well as dead bark are broken off. The tool is conrenient because it combines the scraper, chisel, and worming point, but its conrenience can not offset the better work of the ordinary chisel and knife.

There are two periods during the winter and the spring months when worming can be done to adrantage. Worms are from half to full grown and can be easily seen during the winter. They are more or less dormant, and if cut out at this time the trees will be spared the later injurs which would follow their feeding during the spring. It is also more convenient to orchardists to dig for borers at this time becatise of a freedom from other work. Spring worming is also quite as effective as when this work is done during the fall. A protective wash should be applied after "worming" has been accomplished. Such a wash acts primaril as a repellent and keeps adult moths from placing their eggs on such treated trees. This wash should be applied during the months of Maj or earl June, when moths are beginning to fly. If the wash is applied after worming in the fall it deteriorates and cracks and falls awa from the tree before the time when oriposition occurs. It is considered just as good practice to dig the borer's during the fall as in the spring, but in an case the wash should again be applied in May or earl June. The wash also serves in a secondary way to render the labor of subsequent worming much more easy and rapid. The dirt and bark scalings fall from the washed tree more easily than from those unwashed, and the masses of frass, indicating the presence of borers, are also more easily discorered.

FORMULAS FOR WASHES USED.

The following washes hare been used extensively for controlling borers in the Santa Clara Talley and elsewhere:

Formula No. 1.-The lime-crude oil mixture: Place about 50 pounds of rock lime in a barrel and slake with 10 or 15 gallons of warm water; while the lime is boiling, slowly pour in 6 or $S$ gallons of heary crude oil, and stir thoroughly. Add enough water to make the whole a heary paste. The wash should be applied immediately with a heavy brush.

Formula No. 2.-The lime-sulphur-salt mixture: Place about 25 pounds of rock lime in a barrel and slake with warm water. Add 2 quarts of sulphur and 2 or 3 handfuls of salt while the lime is still boiling. This wash is heavy and is applied with a krush. 
Formula No. 3.-Lime, coal tar, and whale-oil soap: Unslaked lime 50 pounds, coal tar $1 \frac{1}{2}$ gallons, whale-oil soap 12 pounds. Slake the lime in warm water and add the gas tar while the mixture is boiling; dissolve the soap separately in hot water and add this to the lime solution. Add enough water to make a heavy paste.

\section{THE CARBON BISULPHID TREATMENT.}

Carbon bisulphid has been recommended extensively, but its use is now discouraged. Moisture conditions in the soil are so variable that no set rule to determine the amount of liquid which shall be used can be followed, and if the treatment should be preceded by a rain, or if the ground be especially damp, the gas-treated soil can not be left around the tree without immediate injury. The carbon bisulphid method has been more or less successful when an orchardist has done his own work for several years and when he himself places the charge and recognizes the danger. Serious damage is most likely to follow if the remedy is applied by an inexperienced man. Another disadvantage of the carbon bisulphid treatment is that it does not remove the dead or decaying bark above after the cambium layers have been killed by the borers. Hand cutting is never practiced after this treatment, and the tree can never heal its wound as it does when the dead bark is cut away.

\section{METHODS USED AGAINST THE EASTERN PEACH BORER.}

Some of the methods of treating the eastern peach borer have been used, but with little success. Paris green and glue washes have nearly always injured the trees. Paris green is not valuable as an insecticide against borers because the larvæ do not take any part of the wash directly into their stomachs. Hydraulic cement has been used for the purpose of placing a hard coating over the bark so the borers can not penetrate through into the tree. It has been used apparently with only negative results. The hard covering of cement cracks easily as the tree expands and offers little or no resistance to the borers. Numerous combinations of rosin and white or green paints have proved of no value, and there usually follows some injury to the trees. "Mounding" as practiced in the Eastern States consists in building up a cone-shaped pile of dirt around the lower trunks. This is done during the early spring or summer, and its object is to force moths to oviposit high up in the crown of the trees. The young larvæ are thus deceived and enter the bark usually high up under this loose soil and are easily exposed when later the mound of dirt is removed. This method is not practiced against the California peach borer, although it might be used with success. Surrounding the tree with paper or other wrappings has been practiced commonly in the East, but not successfully in California. The long, dry California summers, which necessitate constant spring and summer cultivation, tend to lessen the effectiveness of such wrapping or mounding. 


\section{SUMMARY AND RECOMMENDATIONS.}

The life habits of the California peach borer may be summed up as follows: Adult moths are flying from June to and including September, and are present in maximum numbers during July and August. As they place their egg's immediately after emerging, the period of orrposition conforms with that of the flight of the moths.

The egg stage lasts about two weeks, so that the period when the newly hatched larve are entering the tree is about from the middle of June to the middle of October. The period when they are entering in maximum numbers is from the middle of July to the middle of September. Any repellent or protective wash, therefore, should be applied before the middle of June.

Worming should be practiced during the winter or early spring months, and it is rery important that only sharp tools be used. The bark should be cut and not broken from the tree and so far as possible only dead bark should be cut awar. The most effective wash that can be used in conjunction with the worming method is considered to be the lime-crude oil formula No. 1. Heavy crude oil is thought to be repellent to the borer moth and acts to draw many of the worms out, but it is extremely injurious to some trees. It is apparently safe when combined with lime. Such preparations as residuum oil, gas tar, or asphaltum can be applied directly to the bark of the tree with only a little danger, but common practice has demonstrated that a combination with lime is almost as efficient and far safer than the crude oil alone.

\section{BIBLIOGRAPHY.}

1881. Edwards, Henry.-Papilio, vol. 1, no. 10. Description of species.

1888. KueE, W. G.-Report of Mr. Klee, State Inspector of Fruit Pests. (Bien. Rep. State Board Hort. Cal., p. 243.)

1889. Klee, W. G:-Essay. Report of Tenth Fruit Growers' Conv., Cal. 1889-90. Insect Pests. (Bien. Rep. State Board Hort. Cal., p. 229.)

1891. Coquillett, D. T., and Riley, C. T.-Discussion. (Insect Life, Div. Ent., U. S. Dept. Agr., rol. 3, p. 292.)

1891. Craw, A.-Peach tree borers infesting deciduous trees. (Bul. 68, Cal. State Board Hort.)

1894. Craw, A.-Insect pests and remedies. (Bul. 68, Cal. State Board Hort.)

1895-96. CrAw, A.--Remedies and preventives. (Bien. Rep. Cal. State Board Hort.)

1896. Beutenmüller, My.-Monograph of the Sesiidæ. (Mem. Amer. Mus. Nat. Hist.)

Description of species and notes, page 271 .

1898. EmRHors, E. M.-The crown borer of the peach. (Pacific Rural Press, Dec. 24.)

1899. EhrHorx, E. M.-Discussion on peach borers. (24th Cal. State Fruit Growers' Conv.)

1900. CR.AW, A.--Insect pests and remedies. (Bul. i1, Cal. State Board Hort.) 
1898-1901. Fowler, Carroll. -The peach-tree borer. (Rep. Agr. Exp. Sta. Univ. Cal.)

1900. Ehrhorn, E. M.-Some of our common orchard pests. (Pacific Rural Press, Feb. 17.)

1900. Ehrhorn, E. M.-Fighting insect pests. (Pacific Rural Press, Mar. 3.)

1901. Wickson, E. J.-Peach root-borer. (Pacific Rural Press, Nov. 9.)

1902. Woodworth, C. W.-Remedies for peach-tree borer. (Pacific Rural Press, Nov. 8.)

1902. Eнrhorn, E. M.-The California peach-tree borer. (Bul. 143, Cal. Agr. Exp. Sta., Sept.)

Good account with detail of carbon bisulphid treatment.

1903. IsaACs, J.-Pests and diseases of deciduous fruits. (Cal. Fruit Grower, May 15.)

1904. Wickson, E. J.-Crude oil for peach borer. (Pacific Rural Press, Feb. 13.)

1904. Соок, J. O.-Crude oil for the peach borer. (Pacific Rural Press, Mar. 5.) 



\title{
PAPERS ON DECIDUOUS FRUIT INSECTS AND INSECTICIDES.
}

\section{NOTES ON THE PEACH AND PLUM SLUG.}

(Caliroa [Eriocampoides] amygdalina Rohwer.)

\author{
By R. A. Cushman,
} Agent and Expert.

\section{INTRODUCTION.}

On August 7, 1909, the writer's attention was attracted by a peculiar injury to the leaves of a peach tree standing in the yard of the Delta Boll Weevil Laboratory at Tallulah, Madison Parish, La. (See Pl. XI.) This injury consisted in the skeletonizing, with subsequent curling and falling, of the leaves by a small, yellowish-white, sluglike larva, resembling very closely in form the pear slug (Eriocampoides limacina Retz.). Investigation showed that most of the peach trees in the neighborhood were more or less severely injured. On August 16 an abundance of small black sawflies was observed alighting on a variety of trees and shrubs, and it was immediately thought that these were the adults of the sluglike larvæ on the peach trees. From the close resemblance of both the larvæ and the adults to those of the pear slug it was at first supposed that the insect in question must be of that species, but comparison of the adults with the description of the pear slug showed differences. Specimens of the adults were therefore sent to Mr. S. A. Rohwer of the Bureau of Entomology, who stated that they belonged to a species new to science. Mr. Rohwer has described the species as Caliroa (Eriocampoides) amygdalina. ${ }^{1}$

What is undoubtedly the same species was discussed and figured by Prof. H. A. Morgan, in $1897,{ }^{2}$ under the name Caliroa (Selandria) obsoletum, and the common name "peach and plum leaf sawfly." His article covers a little more than 3 pages, and embraces notes on the biology and natural enemies of the species and remedial measures. 
Owing to the lateness of the season and the press of other work in the fall of 1909, very little in the way of biological studies of this new species could be accomplished, although several unsuccessful attempts were made to carry the larvæ through to the adult stage.

\section{OBSERVATIONS ON THE PEACH AND PLUM SLUG IN 1910.}

In the spring of 1910 a careful watch was kept for the insects, and the earliest recorded observation was made on April 1, when two adult sawflies were observed on a peach tree. This is probably rery near to the first date of appearance of the species, since careful search did not reveal larvæ until April 7. On this date 6 larvæ one-third grown and 5 eggs were found. Morgan (l. c.) states that the adults may be seen at any time from the middle of March until cold weather. His observations were made at Baton Rogue, La., about 130 miles south of Tallulah, La.

On April 21 several larvæ were taken, feeding on the leares of a plum tree in the laboratory yard. From this time on, and under generally warm, dry weather conditions, the infestation increased gradually until April 24, when a severe frost killed all but a rery few of the immature stages, including all of those directly under observation on the trees. Following the freeze came a long, cold drought, unbroken until May 18 and followed by about a week of daily heavy rains. This, in turn, was followed by more cold weather. From the middle of June until the first week in July there were almost daily heavy rains. This combination of unfarorable weather conditions held the species in check to such an extent that it was difficult to find it in any stage. On July 12, 7 full-grown larva and a number of small larvæ were found, the latter probably hatched since the last rain. None between these two stages was observed. After this time frequent observations were made and considerable rearing work done.

While before the freeze of April 24 all of the trees in the laboratory yard had suffered about equally from the depredations of the insects, from this time until about the middle of August the infestation was confined almost entirely to two trees, which stood within a few feet of the north side of the house, and which were further sheltered by a large pear tree and a persimmon tree. For a long time the injury was practically confined to the lower branches close to the house and under the pear and persimmon trees. But as the season adranced and the supply of suitable leares in those locations failed the infestation spread orer these two trees and to the other peach trees and the plum trees in the yard. Whether it is the normal habit of the species to confine its work as closely as possible to its breeding place, or whether the concentration noted was due to the fact that the adults which survived the freeze sought a sheltered location for depositing their eggs, is not quite clear. However, the earlier 
Plate XI.

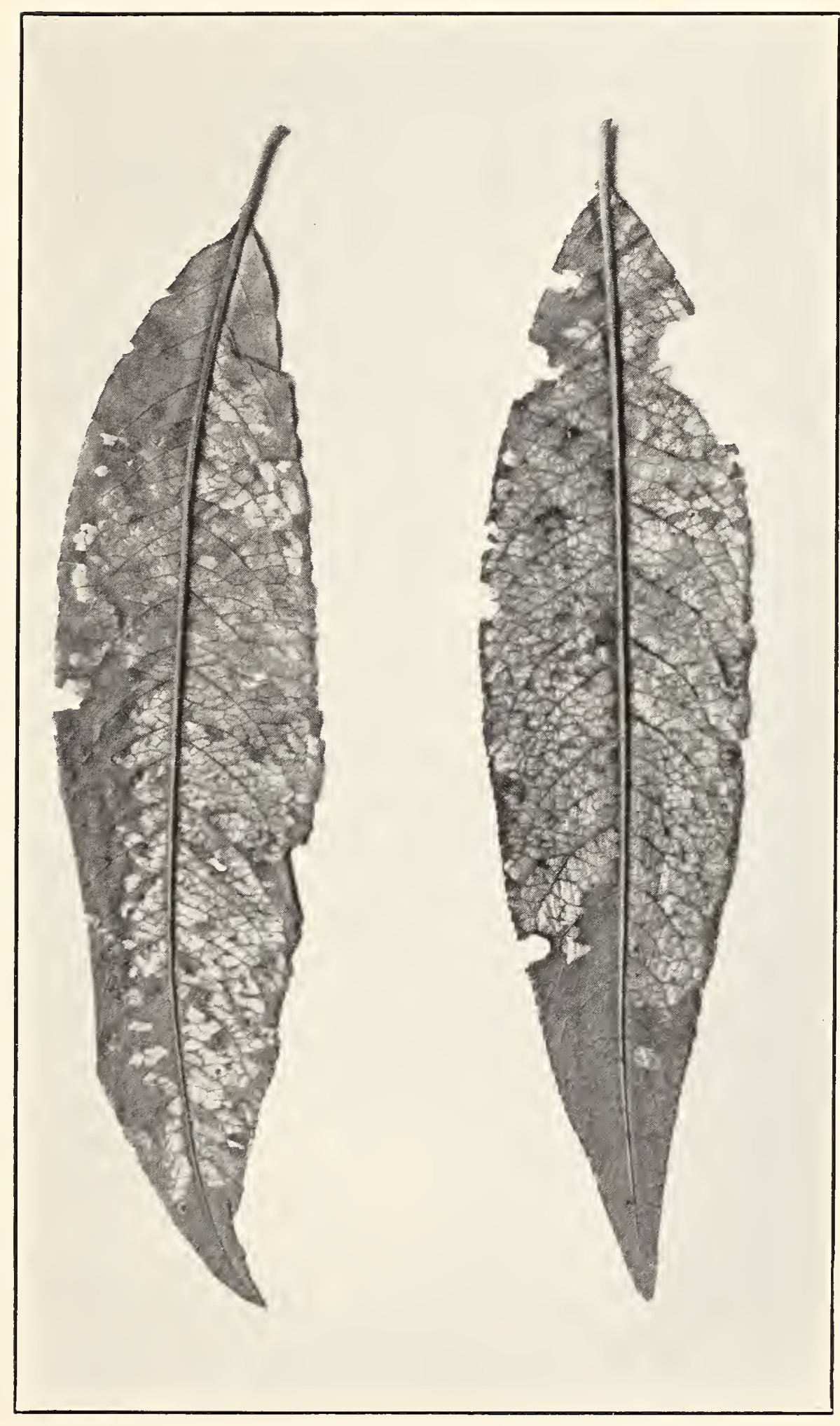

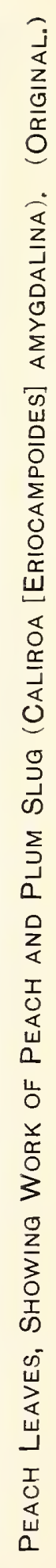



observations seem to indicate that the females normally infest the lower branches first, gradually going higher and higher as the destruction of the lower leaves progresses.

On September 15 occurred a very hard shower, accompanied by a high wind, that destroyed a large percentage of the larvæ that were on the trees at the time. This constituted another setback from which the species had hardly recovered when cold weather set in.

On October 5 practically all of the accessible foliage of the trees in the yard was examined and no stage of the sawfly found, except 8 eggs. These were all located on one leaf and had apparently all been parasitized.

In the earlier attemptis at lifehistory work great difficulty was experienced on account of the delicacy of the young larvæ and the large death rate among them when transfer by hand from one leaf to another was attempted. In addition to this, it was found impossible to follow a given lot of larvæ through to maturity if left on the tree, because of their habit of moving over considerable areas and their consequent loss. The attempts to curb this tendency resulted only in the death of the larvæ. Also, the adults refused to oviposit under any form of restraint. For these reasons a special method of procedure was adopted and a special rearing cage designed. Many uninfested terminal clusters of leaves were marked with blank string tags. These clusters were examined daily, and

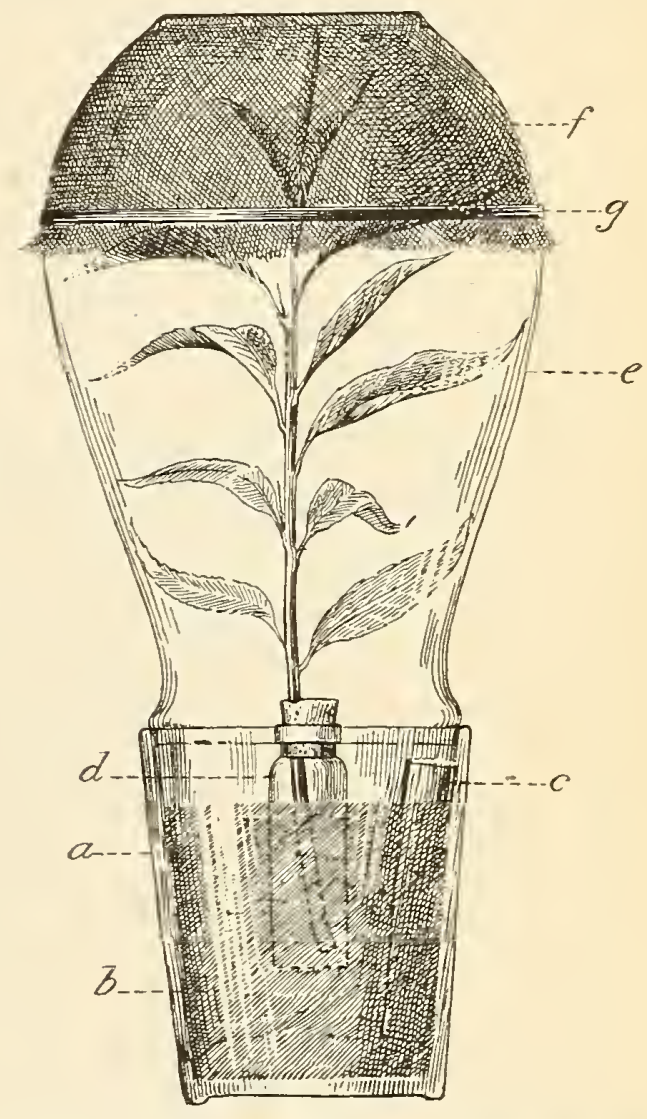

FIG. 23.-Cage used in rearing the peach and plum slug: $a$, Tumbler; $b$, sand for pupation of the insects; $c$, tube, open at both ends, for moistening sand from bottom; $d$, vial of water for keeping food fresh; $e$, lantern chimney; $f$, cheesecloth cover; $g$, rubber band. Reduced. (Original.)

when eggs were found on any of the leaves the infested leaves were marked by clipping the tips and a lot number was placed on the tag, the number corresponding to a card on which notes were recorded. The leaf cluster was then allowed to remain on the tree until just before or just after the hatching of the eggs, when the whole cluster was cut off with a long stem and transferred to the rearing cage. This cage (fig. 23) consisted of a tumbler of sand, into the center of which was thrust a vial and at the side a tube open at both ends. The stem was placed in water in the vial and held upright by a perforated cork. The tube reached well toward the bottom of the tumbler, and was for the purpose of watering the sand without 
puddling the surface. Over this was placed a lantern chimney upside down, the top of the chimney just fitting inside the top of the tumbler. A piece of cheesecloth over the open end of the chimney completed the cage.

About two days after hatching the larvæ. were transferred to fresh foliage, and thereafter the foliage was changed as often as necessary. Even with this care only a small percentage of the individuals confined were carried through to maturity, and many of the lots were complete failures. However, a great deal of information concerning the life history and habits of the species was obtained.

\section{LIFE HISTORY.}

\section{THE ADULT.}

The adult sawflies (see fig. $24, g$ ) are very active little insects. If one is observed on a leaf it will be seen to run back and forth across the leaf on the upper side, apparently peering orer the edge, occasionally stopping for a moment at one of the nectaries at the base of the leaf and sipping the nectar. This sort of food seems to constitute their diet, as, in addition to visiting the peach-leaf nectaries, they were also observed visiting near-by cotton plants for nectar and honeydew, and one was seen on Japanese quince.

The adults first appear in the spring, in the latitude of Tallulah, about the 1st of April and can be found at any time thereafter until cold weather in the fall. Morgan (loc. cit.) observed that the adults appeared most abundantly toward the end of each month, and considered this as an indication of the different broods. This tendency was not noticed at Tallulah. Moreover, eggs and larvæ of all sizes could be observed at the same time, and it hardly appears that there would be any such distinctness of broods. During the year there are probably seren generations of the earliest individuals in the latitude of Tallulah, but owing to the confusion resulting from the overlapping of generations, it is impossible to determine the exact number. Six of the seren are summer generations and the serenth is the hibernating generation. Of the latest individuals of each generation there are probably not more than three or four summer broods.

oriposition.

The act of oriposition was not observed, but from the position of the egg it would seem that the female inserts the ovipositor in the leaf from the upper side, usually close to the midrib or one of the larger veins, and by moving it about from side to side separates the lower epidermis from the other leaf tissues in a space about one and onehalf millimeters in diameter and more or less circular in outline. In 
the cavity thus formed the egg is placed. (See fig. 24, a.) The probability that this is the method of oviposition is supported by the fact that the adult was never observed on the underside of the leaf, but always on the upper side. Moreover, the pear slug, which is closely related to this species, performs the same operation from the underside of the leaf, depositing the egg just beneath the upper epidermis. Morgan (loc. cit.) mistook the portion of the lower epidermis, which forms the floor of the nidus, for a "mucilaginous secretion which extends beyond the real egg and produces a much larger surface for attachment." 'That this idea was erroneous can be easily seen by dissecting the nidus.

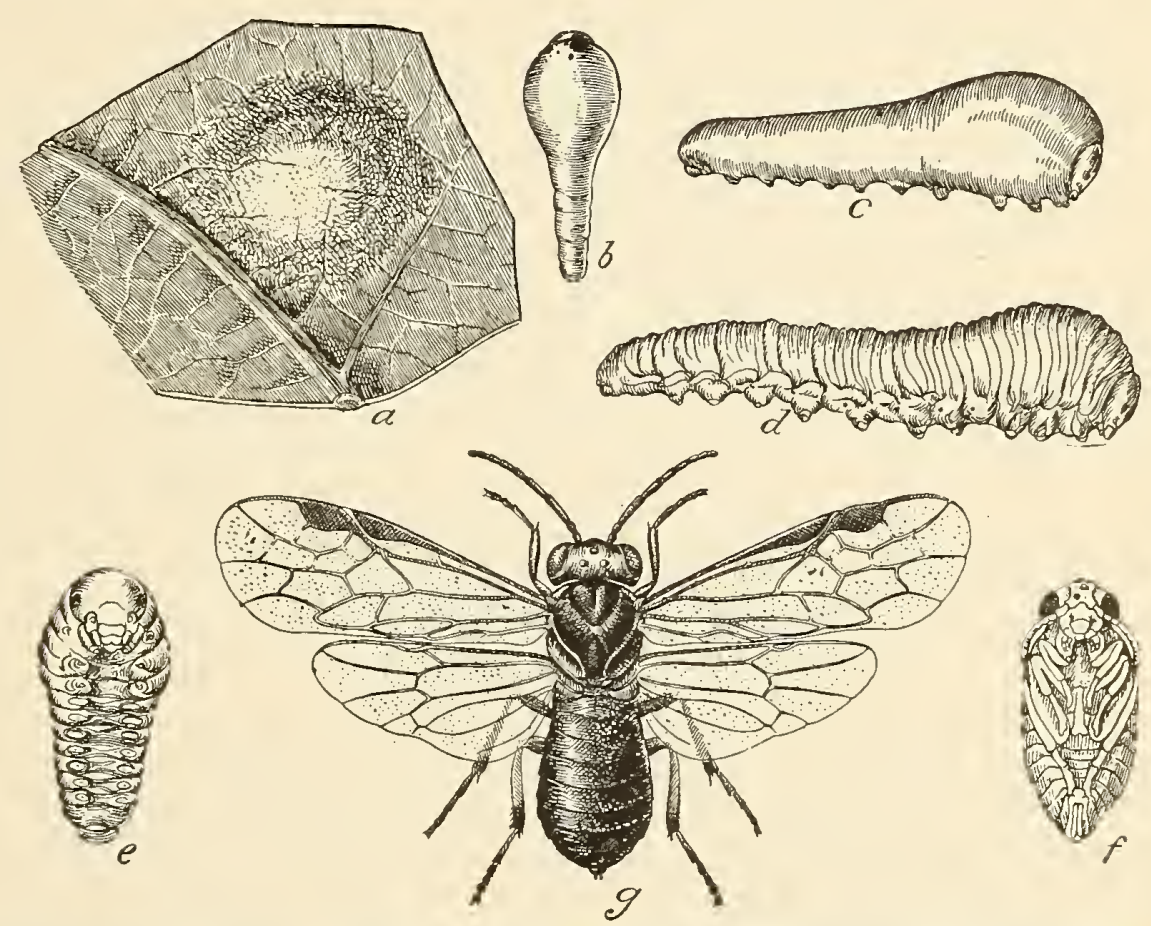

FrG. 24.-Developmental stages of peach and plum slug: $a$, Egg in situ; $b$, newly hatched larva; $c$, larva nearly full grown; $d$, larva after last molt, ready to enter ground for pupation; $e$, prepupa; $f$, pupa; $g$, adult. All much enlarged. (Original.)

In selecting a leaf for oviposition the female usually chooses one some distance back from the terminal bud but one which is still tender. The fresh terminal leaves and the oldest tough ones seem to be avoided, although rather tough leaves are preferred to the newest growth.

The number of eggs in a single leaf may vary from 1 to 25 . It seems likely that a female, after selecting a suitable leaf, may deposit many eggs in it. This conclusion is strengthened by the fact that on April 9, within 9 days of the first appearance of the adults, and when infested leaves were very scattered, one leaf was found which contained 25 eggs.

In some leaves the location of each egg is indicated on the upper side by a small, reddish-purple spot. 
THE EGG.

The egg is transparent white, ovoid, slightly more than one-half a millimeter in its longest diameter, with one side slightly more rounded than the other as in the egg of the pear slug. In eggs in which incubation has continued for some time the developing larra can be easily distinguished.

The incubation period of 74 eggs was determined (see Table I), and it varied from 4 to 6 days, with an average of 4.9 days.

TABJ.E I.-Incubation period of the peach and plum slug, Tallulah, La., 1910.

\begin{tabular}{|c|c|c|c|c|}
\hline Lot No. & $\begin{array}{l}\text { Date of } \\
\text { oviposi- } \\
\text { tion. }\end{array}$ & $\begin{array}{c}\text { Date of } \\
\text { hatching. }\end{array}$ & $\begin{array}{l}\text { Number } \\
\text { of indi- } \\
\text { riduals. }\end{array}$ & $\begin{array}{l}\text { Incuba- } \\
\text { tion } \\
\text { period. }\end{array}$ \\
\hline I3. & Apr. 14 & Apr. 18 & 1 & Days. $_{4.0}$ \\
\hline & Apr. 13 & ...do...... & 1 & 5.0 \\
\hline I10. & Aug. 10 & Aug. 14 & 6 & 4.0 \\
\hline I11. & Aug. 11 & Aug. 16 & 3 & 5.0 \\
\hline $\begin{array}{l}\text { I12.. } \\
\text { I13.. }\end{array}$ & Aug. 12 & $\begin{array}{l}\ldots \text { do..... } \\
\ldots \text { do..... }\end{array}$ & & $\begin{array}{l}5.0 \\
4.0\end{array}-10$ \\
\hline & - & Aug. 17 & $\frac{1}{2}$ & 5. 0 \\
\hline I14. & ... do..... & Aug. 16 & 1 & 4.0 \\
\hline I15. & Aug. 14 & Aug. 19 & 22 & 5.0 \\
\hline $\begin{array}{l}\text { II6.. } \\
\text { I17. }\end{array}$ & Aug. 21 & Aug. 27 & $\begin{array}{r}29 \\
4\end{array}$ & $\begin{array}{l}5.0 \\
6.0\end{array}$ \\
\hline Total and a rerage... & & & 74 & 4.9 \\
\hline
\end{tabular}

THE LARVA.

As is the case with the pear slug, the larra in escaping from the egg cuts a crescent-shaped slit in the wall of its cell. When first hatched (fig. $24, b$ ) it is creamy white with the head slightly darker and the eyes and mouth parts brown, and lacks the slimy covering. It has, in addition to the 6 true legs, 7 pairs of prolegs. It begins to feed almost immediately, becoming quickly coated with the secretion, and within half an hour a line of green appears down its whole length, due to the food in the alimentary canal.

The first damage by the larva consists in rery small pinholes eaten into the leaf from the underside, all of the tissue being remored except the upper epidermis. As the larva grows and its jaws become stronger the size of the eaten patches increases until they become large blotches. The upper epidermis is, howerer', nerer eaten.

The larva grows rapidly (see fig. 24, c), molting four times during its growth. The first instar is from less than 2 to 4 dars in duration, averaging about 2 days. The second and third instars are of nearly Iike duration, and the fourth about 3 days in length, the total feeding period being about 9 or 10 days in duration in warm weather. Two individuals were recorded in which the feeding period lasted for 22 days, but these were from a lot which was under observation during 
the cold weather of April, and represent the result of abnormal conditions.

Unlike its congener, the pear slug, the larva does not eat its exuvium.

The escape from the exuvium is made through an opening at the head end, the larva simply crawling out of its old skin and learing it as a narrow line of slime on the surface of the leaf.

Immediately after molting the larvæ very freqeuntly wander away from the leaf on which they have been feeding to another, sometimes 2 or 3 feet distant.

During the first four instars the larva is of a peculiar sluglike appearance, swollen in front and covered with the slimy secretion which hides the segmentation of its body. The head is pale brown and the eye spots darker. The body is translucent and the course of the alimentary canal can be traced by the green food within. On molting for the fourth time, however, it loses its slimy coating and appears as an opaque, yellowish, caterpillar-like larva (fig. 24, d), in which the segmentation can be distinctly seen. It is from fivesixteenths to three-eighths of an inch in length.

During the last molt the larva deposits several pellets of excrement within the exuvium.

Tables II to $\mathrm{V}$ show the data obtained on the duration of the different larval stages, and Table VI gives the data for the total feeding period.

TABLE II.-First larval period of the peach and plum slug, Tallulah, La., 1910.

\begin{tabular}{|c|c|c|c|c|}
\hline Lot No. & $\begin{array}{l}\text { Date of } \\
\text { hatching. }\end{array}$ & $\begin{array}{l}\text { Date of } \\
\text { first molt. }\end{array}$ & $\begin{array}{l}\text { Number } \\
\text { of indi- } \\
\text { viduals. }\end{array}$ & $\begin{array}{l}\text { First } \\
\text { larval } \\
\text { period. }\end{array}$ \\
\hline 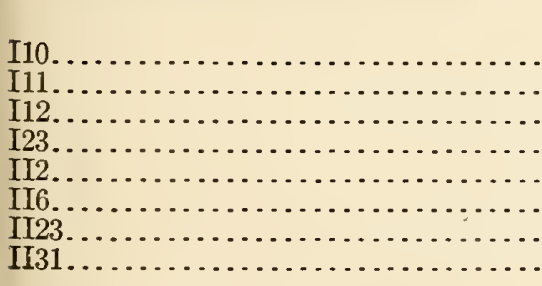 & $\begin{array}{l}\text { Aug. } 14 \\
\text { Aug. } 16 \\
\text { Sept...21 } \\
\text { Apr. } 9 \\
\text { Apr. } 13 \\
\text { Aug. } 25 \\
\text { Sept. } 20\end{array}$ & $\begin{array}{l}\text { Aug. 15 } \\
\text { Aug. 17 } \\
\text { Aug. 18 } \\
\text { Sept. 24 } \\
\text { Apr. 11 } \\
\text { Apr. 15 } \\
\text { Aug. 27 } \\
\text { Sept. 24 }\end{array}$ & $\begin{array}{r}6 \\
3 \\
3 \\
2 \\
10 \\
5 \\
4 \\
1\end{array}$ & $\begin{array}{r}\text { Days. } \\
1.0 \\
1.0 \\
2.0 \\
3.0 \\
2.0 \\
2.0 \\
2.0 \\
4.0\end{array}$ \\
\hline Total and average... & & & 34 & 1.9 \\
\hline
\end{tabular}

TABLE III.-Second larval period of the peach and plum slug, Tallulah, La., 1910.

\begin{tabular}{|c|c|c|c|c|}
\hline Lot No. & $\begin{array}{c}\text { Date of } \\
\text { first } \\
\text { molt. }\end{array}$ & $\begin{array}{c}\text { Date of } \\
\text { second } \\
\text { molt. }\end{array}$ & $\begin{array}{l}\text { Number } \\
\text { of indi- } \\
\text { viduals. }\end{array}$ & $\begin{array}{l}\text { Second } \\
\text { larval } \\
\text { period. }\end{array}$ \\
\hline I23. & \multirow{5}{*}{$\begin{array}{l}\text { Sept. } 24 \\
\text { Aug. } 27 \\
\text { Sept. } 20 \\
\text { Sept. } 21 \\
\text { Sept. } 24\end{array}$} & \multirow{5}{*}{\begin{tabular}{|c} 
Sept. 26 \\
Aug. 29 \\
Sept. 23 \\
$\ldots$ do.... \\
Sept. 26
\end{tabular}} & & Days. \\
\hline III 23 & & & 5 & 2.0 \\
\hline 1129. & & & 20 & $\begin{array}{l}3.0 \\
2.0\end{array}$ \\
\hline II31. & & & 1 & 2.0 \\
\hline Total and average... & & & 35 & 2.2 \\
\hline
\end{tabular}


TABLE IV.-Third larval period of the peach and plum slug, Tallulah, La., 1910.

\begin{tabular}{|c|c|c|c|c|}
\hline Lot No. & $\begin{array}{l}\text { Date of } \\
\text { second } \\
\text { molt. }\end{array}$ & $\begin{array}{l}\text { Date of } \\
\text { third } \\
\text { molt. }\end{array}$ & $\begin{array}{l}\text { Number } \\
\text { of indi- } \\
\text { viduals. }\end{array}$ & $\begin{array}{l}\text { Third } \\
\text { larval } \\
\text { period. }\end{array}$ \\
\hline 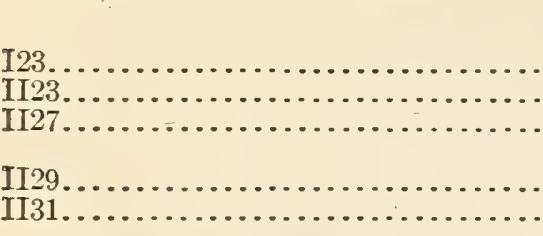 & $\begin{array}{l}\text { Sept. } 26 \\
\text { Aug. } 29 \\
\text { Sept. } 23 \\
\\
\text {..do..... } \\
\text { Sept. } 20\end{array}$ & $\begin{array}{l}\text { Sept. } 28 \\
\text { Aug. } 31 \\
\text { Sept. } 25 \\
\text { Sept. } 26 \\
\text { Sept. } 25 \\
\text { Sept. } 28\end{array}$ & \begin{tabular}{r|}
2 \\
1 \\
5 \\
4 \\
16 \\
1
\end{tabular} & $\begin{array}{r}\text { Days. } \\
2.0 \\
2.0 \\
2.0 \\
3.0 \\
2.0 \\
2.0\end{array}$ \\
\hline Total and average... & & & 29 & 2.1 \\
\hline
\end{tabular}

TABLE V.-Fourth larval period of the peach and plum slug, Tallulah, ia., 1910.

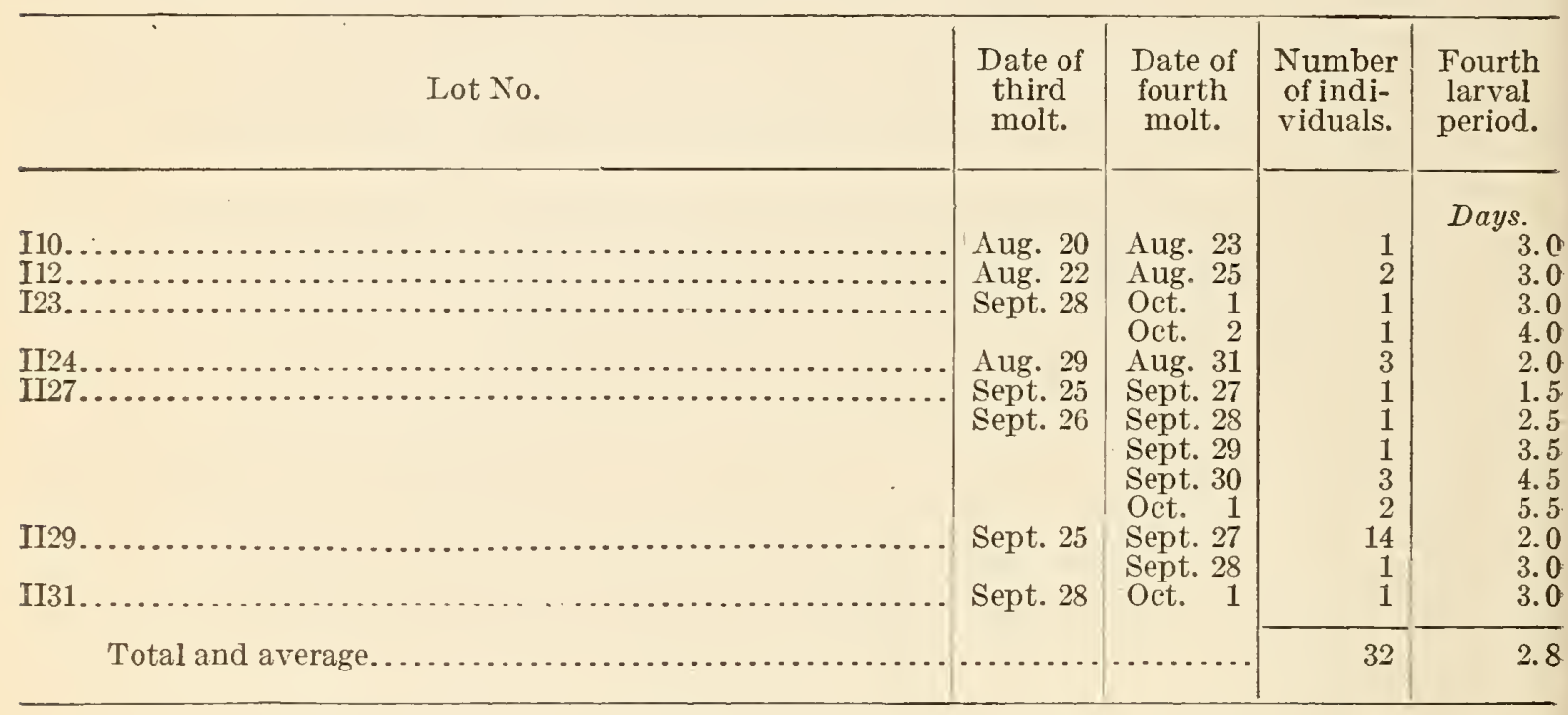

TABLE VI.-Total feeding period of the peach and plum slug, Tallulah, La., 1910.

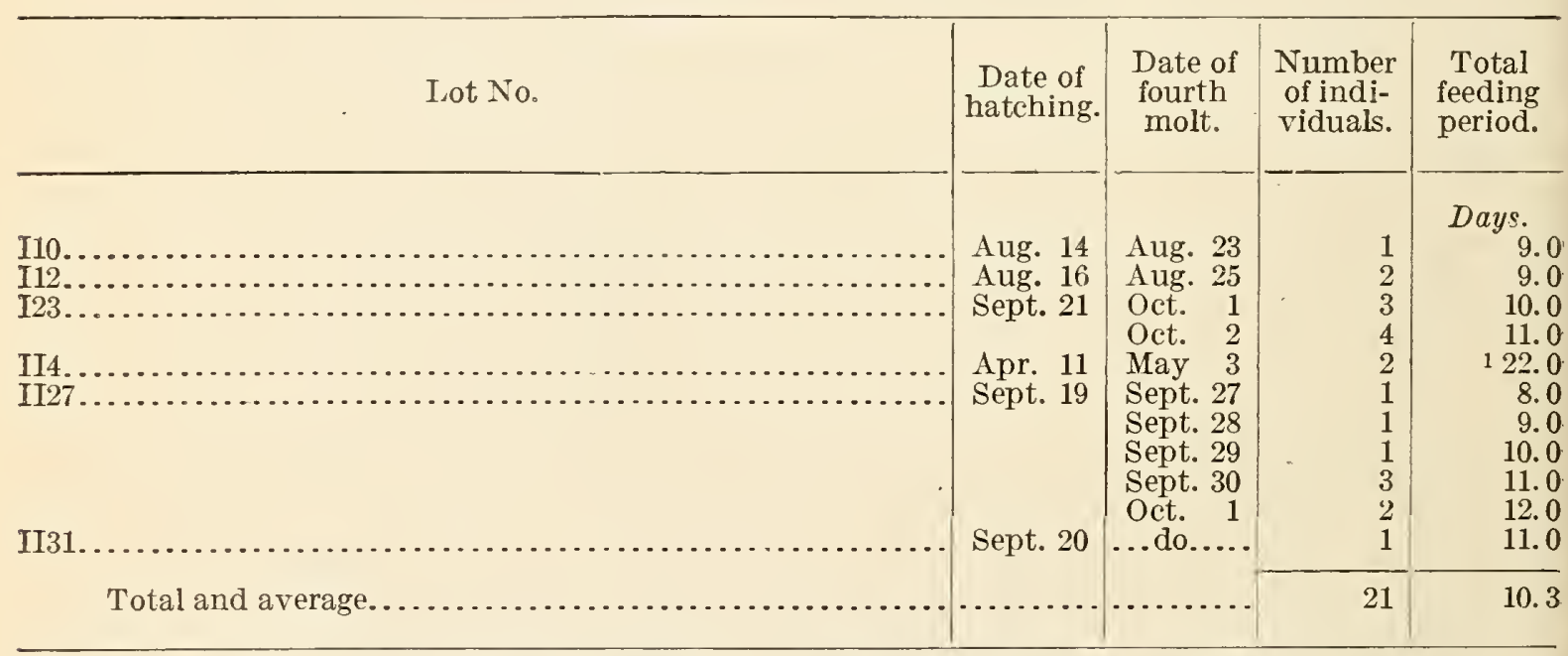

1 These 2 were developing during unusually cold weather for the season and are omitted from the average.

\section{THE PREPUPA.}

After molting for the last time the larva crawls or drops to the ground where it voids the entire contents of the alimentary canal, burrows into the soil from one-half an inch to 3 inches, and constructs 
an oval cell somewhat less than one-fourth of an inch long in its greatest diameter. If the cell be opened the larva will be seen to have changed its form considerably. (See fig. $24, e$.) It is now like a mummy of its former self. It is only about half its original size when it entered the soil, has lost the power of locomotion, and is much shriveled. This stage may be called the prepupa. Marlatt ${ }^{1}$ terms $^{\text {. }}$ the corresponding stage of the pear slug the "contracted larva."

In this form the insect remains for a period, depending on the temperature, of from 5 to 7 days before pupation. Some individuals, as in the case of the pear slug, which seem to be set aside to guard against any catastrophe which might exterminate the species, remain in this condition until long after their fellows have matured, before finishing their life cycle. In one case a living prepupa was found 28 days after the latest adult reared from the same lot of larvæ had emerged. When the work was finished, on October 20, after cold weather had set in, all of the cages were examined. In this examination all of the living stages found were in the prepupal condition. From this it appears that the species must hibernate in this form.

\section{THE PUPA.}

(Fig. 24,f.)

The pupal period varies in duration from 2 to 4 days, according to the temperature. The data on the total quiescent period (i. e., prepupa plus pupa) is shown in Table VII.

TABle VII.-Quiescent period of peach and plum slug, Tallulah, La.

\begin{tabular}{|c|c|c|c|c|}
\hline Lot No. & $\begin{array}{l}\text { Date of } \\
\text { fourth molt. }\end{array}$ & $\begin{array}{l}\text { Date of } \\
\text { emer- } \\
\text { gence. }\end{array}$ & $\begin{array}{c}\text { Number } \\
\text { of indi- } \\
\text { viduals. }\end{array}$ & $\begin{array}{l}\text { Quies- } \\
\text { cent } \\
\text { period. }\end{array}$ \\
\hline 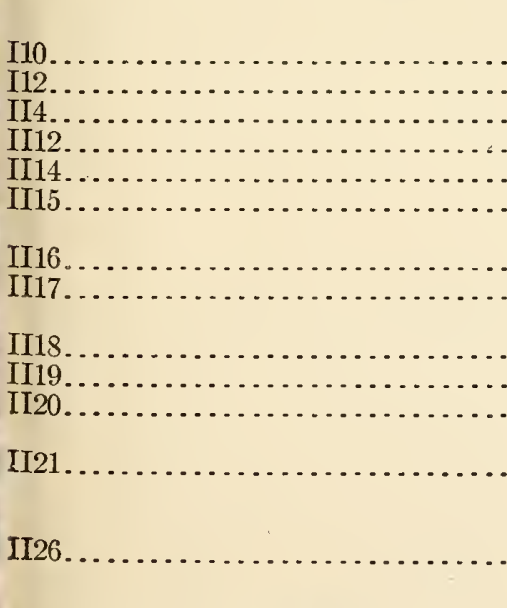 & $\begin{array}{l}\text { Aug. } 23 \ldots . . \\
\text { Aug. } 25 \ldots . . \\
\text { May } 3 . \ldots . \\
\text { May } 22-29 . . \\
\text { July } 18 . \ldots . \\
\text { July } 14-17 . . \\
\text { Aug. } 12 \ldots . . \\
\text { Aug. } 14 \ldots . \\
\text { Aug. } 18 \ldots . . \\
\text { Aug. } 21 \ldots . . \\
\text { Aug. } 23-25 . . \\
\text { Aug. } 26-27 . . \\
\text { Sept. } 10-11 . .\end{array}$ & $\begin{array}{lr}\text { Sept. } & 1 \\
\text { Sept. } & 3 \\
\text { May } & 12 \\
\text { May } & 9 \\
\text { July } & 26 \\
\text { July } & 23 \\
\text { July } 24 \\
\text { Aug. } 19 \\
\text { Aug. } 22 \\
\text { Aug. } 23 \\
\text { Aug. } 25 \\
\text { Sept. } 16 \\
\text { Sept. } 1 \\
\text { Sept. } 3 \\
\text { Sept. } 4 \\
\text { Sept. } 4 \\
\text { Sept. } 5 \\
\text { Sept. } 20 \\
\text { Sept. } 22\end{array}$ & $\begin{array}{l}1 \\
2 \\
1 \\
1 \\
1 \\
1 \\
1 \\
3 \\
4 \\
1 \\
2 \\
1 \\
2 \\
7 \\
2 \\
1 \\
1 \\
1 \\
1\end{array}$ & $\begin{array}{r}\text { Days. } \\
9.0 \\
9.0 \\
9.0 \\
13.5 \\
8.0 \\
7.5 \\
8.5 \\
7.0 \\
8.0 \\
9.0 \\
7.0 \\
26.0 \\
8.0 \\
10.0 \\
7.5 \\
8.5 \\
9.5 \\
9.5 \\
11.5\end{array}$ \\
\hline Total and average.... & & & 34 & 9.0 \\
\hline
\end{tabular}

1 U. S. Dept. Agr., Div. Ent., Cir. 26, 2d ser., 1897.

2 This individual held over till the next generation before emerging and is omitted from the average. 
TOTAL DEVELOPMENTAL PERIOD.

The total developmental period varies from 20 to 28 or 30 days in the majority of individuals, although in those individuals of each generation which hold over for a time after the normal time of emergence it may be from twice to several times as long as this. This portion of the life history was actually determined for only three individuals. One of these required 22 days and the other two 23 days each. One other was carried through the total period with the exception of the incubation period. Estimating this at 5 days the total developmental period for this individual was 36 days. During the time it was developing, April and May, the weather was very cold and the larval period was 22 days in duration.

\section{EXTENT OF DAMAGE.}

So serious a menace is this insect to the peach and plum trees that, in a favorable season, the trees are completely defoliated in August. Morgan figures a plum orchard which was practically defoliated as early as May 22, 1897, when the photograph (Pl. XI) was taken.

In the struggle to repair the damage of the slugs, the trees keep putting out new leaves and forming new wood, which causes them to enter the winter unprepared and less able to withstand freezing. Many of them are thus winter-killed.

Morgan (loc. cit.) quotes a letter from a correspondent in central Louisiana, in which the statement is made that the species "kills an orchard effectually in about two years."

He also makes the following observation: "The attack of this insect upon the American type of plums, such as the Mariana, and the almost entire immunity of the Japanese varieties is very noticeable. Peaches seem worse affected upon the lighter soils of the State."

A heavily infested tree has a very characteristic appearance in the late season, being entirely bare of foliage except at the tips of the twigs, where tufts of new leaves appear.

\section{NATURAL ENEMIES.}

Although the nauseous, slimy covering of the larva of this species undoubtedly protects it from many insects and other animals which might otherwise attack it, it is not entirely without natural enemies. Morgan (loc. cit.) mentions two species of mud daubers, which were observed constantly visiting the infested trees and carrying away the larger larvi, and records the bordered soldier-bug (Stiretrus pulchella [=anchorago Fab.]) as feeding on them. He also records having observed a hymenopterous parasite, Trichogramma minutum, ovipositing in the eggs of the sawfly. The adults of the parasite appeared in 8 days (May 22 to May 30, 1896). 
The latter species was not reared by the writer, but on October 5 8 eggs, from which this parasite had probably emerged, were found. Emergence is through a small round hole a little to one side of the center of the egg.

In addition to the above enemies several specimens of a new species of ichneumon fly were reared from the larva at Tallulah. This species has been described by Mr. II. L. Viereck, of the Bureau of Entomology, as Hyperallus calirox. ${ }^{1}$ It is shown, much enlarged, in figure 25.

Specimens of this parasite were reared from larvæ which had been confined in the rearing cages for varying periods before entering the ground. The youngest larva, from which a parasite was reared, was removed from the tree on April 7, when it was about one-third grown, that is, 3 or 4 days from the egg. The parasite emerged 35 days later, on May 12. This period is, however, rather longer than the average, since this individual was developing during the cold weather of April and May. All of the other specimens were reared from larva which were nearly full grown at the time they were removed from the tree and placed in cages. From larvæ placed in a cage on April 16, 2 parasites were reared on May 17 , a period of 31 days.

From larvæ placed in a cage on

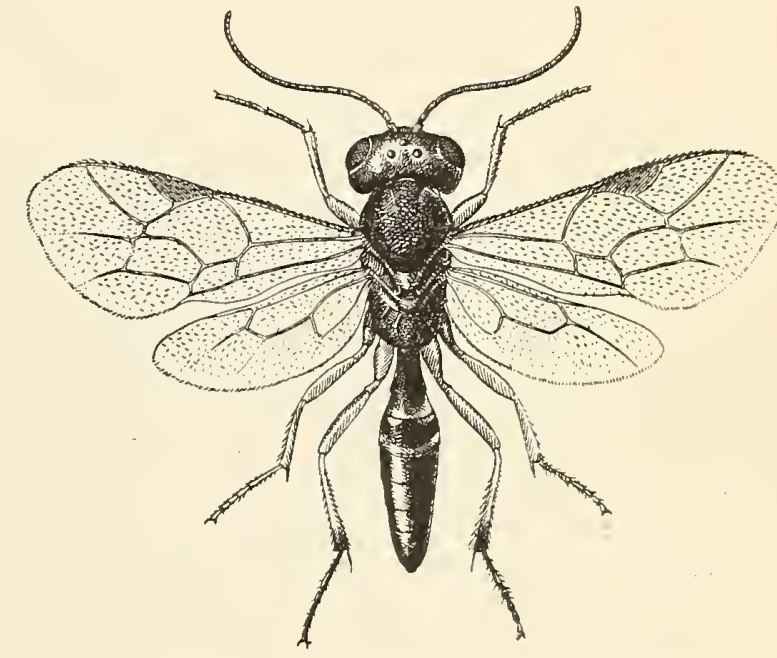

Fig. 25.--Hyperallus calirox, a parasite of the peach and plum slug. Much enlarged. (Original.)

July 12,2 parasites were reared on August 10, a period of 29 days. An adult of the host emerged on July 26, 15 days before the parasites appeared.

From larvæ taken on August 10, two parasites were reared on September 1, a period of 22 days. Three adult sawflies emerged on August 19, 13 days before the parasites.

From larva confined in a cage on August 12, one parasite was reared on September 3 (period, 22 days), one on September 4 (period, 23 days), and one on September 7 (period, 26 days). Adult sawflies were reared from this lot on August 20,22, and 23, an average of 12.5 days before the first parasite, 13.5 days before the second, and 16.5 days before the last parasite.

From larvæ removed from the tree on August 19, two parasites were reared on September 18, a period of 30 days. 'The only adult sawfly reared from this lot was one which evidently remained over time as a prepupa and emerged September 16, only two days ahead of the parasite. 
The developmental period of the parasite is somewhat longer normally than that of its host.

The data on the development of the parasite are given in Table VIII.

TABLE VIII.-Data on rearing of Hyperallus caliroæ.

\begin{tabular}{|c|c|c|c|c|c|c|c|}
\hline Lot No. & $\begin{array}{c}\text { Date of } \\
\text { confine- } \\
\text { ment of } \\
\text { larvæ. }\end{array}$ & $\begin{array}{l}\text { Condition of larvæ } \\
\text { when confined. }\end{array}$ & $\begin{array}{c}\text { Date } \\
\text { adult } \\
\text { sawflies } \\
\text { emerged. }\end{array}$ & $\begin{array}{c}\text { Date } \\
\text { parasites } \\
\text { emerged. }\end{array}$ & $\begin{array}{l}\text { Number } \\
\text { of para- } \\
\text { sites } \\
\text { reared. }\end{array}$ & $\begin{array}{l}\text { Period } \\
\text { from } \\
\text { confine- } \\
\text { ment of } \\
\text { larvæ to } \\
\text { emer- } \\
\text { gence of } \\
\text { parasites. }\end{array}$ & $\begin{array}{l}\text { Period } \\
\text { from } \\
\text { emer- } \\
\text { gence of } \\
\text { sawflies } \\
\text { to emer- } \\
\text { gence of } \\
\text { parasites. }\end{array}$ \\
\hline $\begin{array}{l}\text { II1 } \ldots \ldots \ldots \ldots \\
\text { II10 } \\
\text { II14 } \\
\text { II16. } \\
\text { II17 } \\
\text { II19. }\end{array}$ & $\begin{array}{lr}\text { Apr. } & 7 \\
\text { Apr. } & 16 \\
\text { July } & 12 \\
\text { Aug. } & 10 \\
\text { Aug. } & 12 \\
& \\
\text { Aug. } & 19\end{array}$ & 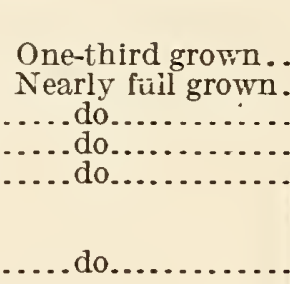 & $\begin{array}{l}\text { None. } \\
\text {.do .... } \\
\text { July } 26 \\
\text { Aug. } 19 \\
\text { Aug. } 20 \\
\text { Aug. } 22 \\
\text { Aug. } 23 \\
\text { 1 Sept. } 16\end{array}$ & $\begin{array}{lr}\text { May } & 12 \\
\text { May } & 17 \\
\text { Aug. } & 10 \\
\text { Sept. } & 1 \\
\text { Sept. } & 3 \\
\text { Sept. } & 4 \\
\text { Sept. } & 7 \\
\text { Sept. } & 18\end{array}$ & $\begin{array}{l}1 \\
2 \\
2 \\
2 \\
1 \\
1 \\
1 \\
2\end{array}$ & \begin{tabular}{r|} 
Days. \\
35.0 \\
31.0 \\
29.0 \\
22.0 \\
22.0 \\
23.0 \\
26.0 \\
30.0
\end{tabular} & \begin{tabular}{r} 
Days. \\
\hdashline... \\
13.0 \\
13.0 \\
12.5 \\
13.5 \\
16.5 \\
2.0
\end{tabular} \\
\hline $\begin{array}{c}\text { Total and aver- } \\
\text { ages........... }\end{array}$ & & & & & 12 & 27.5 & 14.1 \\
\hline
\end{tabular}

1 This sawfly was undoubtedly from a prepupa, which held over beyond the normal time of emergence for the brood, and the figure corresponding to it in the last column is omitted from the average.

The parasite enters the ground in the body of the host and develops within the pupal cell of the latter. When it has entirely consumed its host and is full grown, it makes a very thin, brown, parchmentlike cocoon within the pupal cell and changes to the pupal stage, emerging later as a light-brown and yellowish wasplike fly.

This parasite is evidently not very abundant, as none was seen about the trees, and only 13 individuals were reared from the several hundred larvæ of the sawfly confined.

\section{REMEDIES.}

Lack of time prevented the writer from making any tests of remedies. Without doubt, however, an arsenical spray, such as arsenate of lead, would very effectively destroy these insects, and this poison is advised when the insects occur in sufficient numbers to warrant treatment. The rapid increase in the spraying of peaches and plums with arsenate of lead in self-boiled lime-sulphur wash for the control of the plum curculio and fungous diseases of the fruit will unquestionably result in keeping the peach and plum slug well reduced in orchards. Its occurrence in injurious numbers is to be looked for largely in small unsprayed home orchards, and the remedial measures indicated should be followed when its presence in undue numbers is noted. 


\title{
PAPERS ON DECIDUOUS FRUIT INSECTS AND INSECTICIDES.
}

\author{
THE PEACH BUD MITE. \\ (Tarsonemus waitei Banks, MSS.) \\ By A. L. Quaintance, \\ In Charge of Deciduous Fruit Insect Investigations.
}

\section{INTRODUCTION.}

For the past 15 or 20 years nurserymen in the East have complained of a well-defined trouble of peach nursery stock, resulting from injury to the tender terminal bud of the principal shoot. The injury causes the cessation of further upward growth of the shoot and results in the development from the lateral buds of numerous branches, a condition very objectionable in stock of this class where a single vigorous shoot is desired. There have been several references in literature to this trouble, and entomologists are divided as to the cause, though in most instances a minute mite has been noted as associated with it. The mite in question, however, has not heretofore been examined by a specialist in the Acarina and its systematic position and relationships determined. Mr. Banks has recently been able to do this from material which was obtained from a large nursery in the environs of Philadelphia, and submitted to him during September, 1911.

The mite is now identified as Tarsonemus waitei Banks.

As the trouble is an important one, it has appeared appropriate to bring together at this time, so far as is possible, the recorded facts concerning it, with remarks on injuries caused by some other species of Tarsonemus.

\section{HISTORY.}

Prof. M. B. Waite, of the Department of Agriculture, was undoubtedly first to call attention to this affection, upon which he made careful observations a number of years ago. He was able to determine that a mite was the cause of the trouble, and presented the results of his observations before the Biological Society of Washington at its meeting October 23, 1897, under the title" A New Peach and Plum 
Disease." An abstract of these remarks, published in Science, ${ }^{1}$ is as follows:

Mr. M. B. Waite presented a communication on a new peach and plum disease caused by a species of mite attacking and killing the terminal bud of the very young trees. The resulting loss in the value of the trees was considerable, as many thousand trees would be affected in one nursery. A similar disease prevailed in the Japanese quince.

No further reference to this trouble appears to have been published by Prof. Waite. In Entomological News," under the caption "Preliminary notes upon an important peach-tree pest," Prof. W. G. Johnson states:

In September, 1896, while inspecting the nurseries of Maryland, I found many peach trees dwarfed and stunted, and at first glance attributed it to the black peach aphis (Aphis prunicola Kalt.), Later inspection proved conclusively that the trouble was not caused by that insect, but by some other creature. A lot of trees were examined in my laboratory and I discorered a minute mite (Phytoptidæ) working behind and in the buds. In nearly every instance the terminal bud had been destroyed, thus forcing the laterals. These in turn would grow for a short time and were then killed. As a consequence the trees were crooked, stunted, and not salable, being less than 3 feet in height. They were what I have termed dog-legged trees, on account of their very crooked condition.

Prof. Johnson's note led to some comment by other entomologists, and Prof. F. M. Webster, in the Entomological News, ${ }^{3}$ under the title "The new peach mite in Ohio," reports the finding by Mr. C. W. Mally, in the course of nursery inspection work, of the characteristically injured peach trees, though the depredator was not determined. It is stated that in one rery extensive nursery the greater portion of a block of 500,000 young peach trees was more or less affected and the presence of the pest was noted also in another nursery in the same general region.

Prof. P. H. Rolfs in a note, "The new peach mite," in Entomological News, ${ }^{4}$ called attention to the distribution of a mite which he erroneously thought to be the one referred to by Messrs. Johnson and Webster, namely, a phytoptid, causing a silvering of peach leavesa mite which was subsequently described by Banks under the name Phyllocoptes cornutus from material from the insectary grounds in Washington. A further confusion is evidenced in a note by Mír. Claude Fuller, in Entomological News, ${ }^{5}$ in which attention is called to a silvering of the leares of deciduous fruit trees as noted by him in South Africa and due to the attack of a rery small Phytoptus. This is very probably similar if not identical with Phyllocoptes cornutus.

Messrs. Webster and Mally refer briefly to the subject in an article on "Insects of the Year in Ohio," read before the Association of 


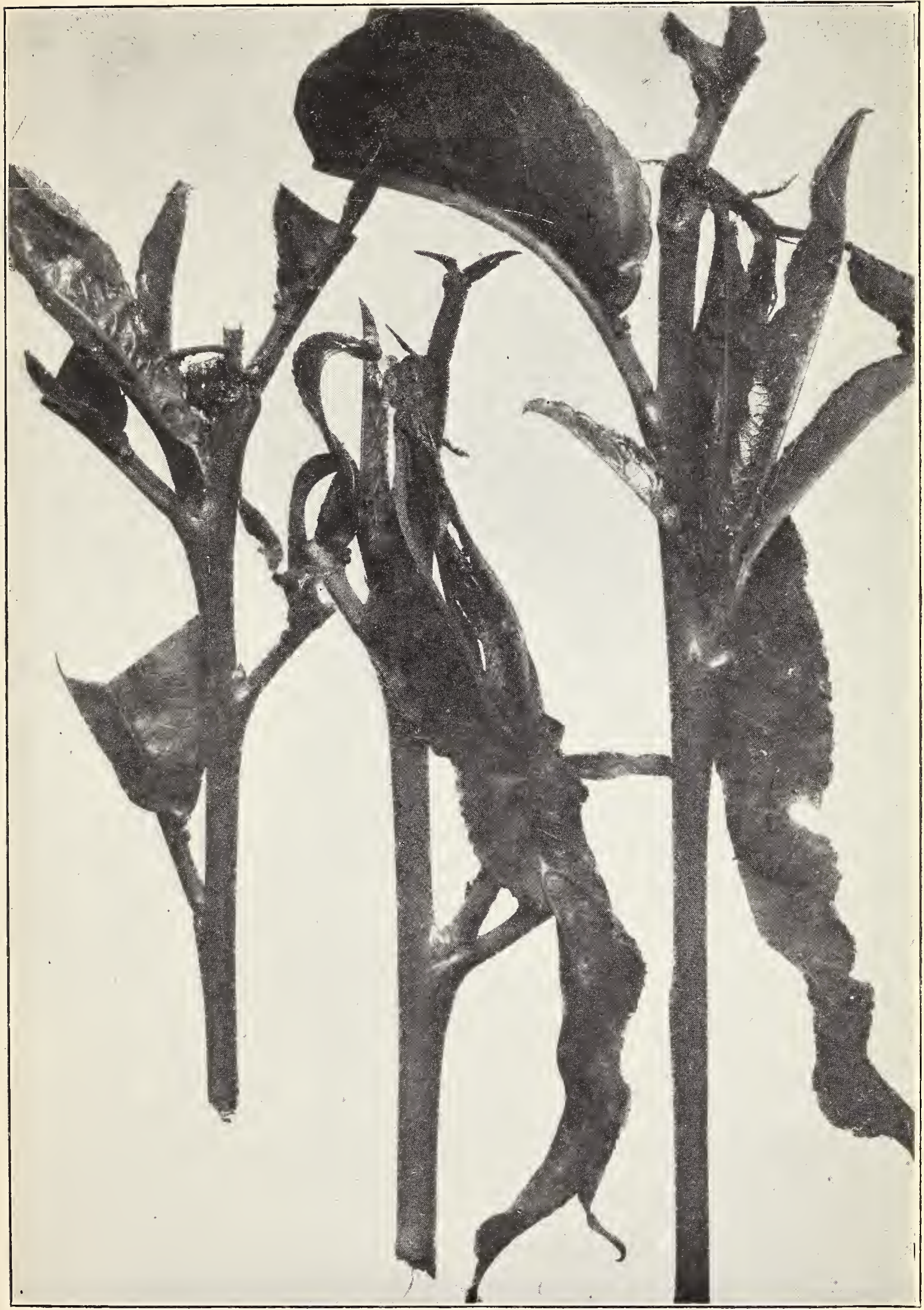

The Peach Bud Mite (Tarsonemus waitei).

Injury about two weeks old to peach shoots by the peach bud mite. The tips of shoots have fallen over and are brown and dry. (Original.) 

Economic Entomologists at their eleventh annual meeting, Columbus, Ohio, in August, 1899, and published in Bulletin No. 20 of the then Division of Entomology. ${ }^{1}$ The injury to peach nursery stock in Ohio was, however, considered to be due to the plant-bug Lygus pratensis L., as no evidence was found of the presence of the mite and the extent of injury had been observed to coincide with the abundance of the plant-bug in the nurseries. Also, as stated by nurserymen, the Lygus had been frequently observed at work.

Dr. John B. Smith described a similar injury to peach in New Jersey under the caption "Peach Thrips," 2 and figures a block of trees badly injured, and also a block of trees which had been sprayed June 9 with undiluted kerosene. In the peach shoots examined by Dr. Smith nothing was found in the dry ones, whereas in every one that was yet moist from 3 to 5 minute, immature thripids were discovered. Dr. Smith's evident conclusion was that the thrips were responsible for the trouble. Also a letter is quoted by Dr. Smith from Prof. W. B. Alwood to the effect that he had worked on the peach thrips since 1891 . He was certain injury was due to a thrips and had determined the insect to be tritici.

In a further note by Prof. Johnson in Entomological News ${ }^{3}$ he calls attention to the symptoms of injury by the peach bud mite, and states that the characteristic silvering of the leaves noted by Rolfs and Fuller had not been noticed by him associated with the new mite in Maryland. On the contrary, trees in the nursery rows affected with the peach bud mite were easily distinguished by their dense green foliage and the bunching of twigs.

In a report of the Virginia State entomologist ${ }^{4}$ Mr. J. L. Phillips treats of this affection at some length under the title "Notes on Thrips, Disbudding Insect, or Stop-back of Peach, as Observed in the Nurseries of Virginia." The author states that many unsightly peach trees growing in nurseries in the State had been noted during the few years previous and that injury appeared to be confined almost entirely to nurseries located in the sandy soils of eastern Virginia, where the trees grow very rapidly when given proper care. Thrips were not observed by Mr. Phillips in sufficient quantity nor in position to fix the responsibility for the disease. On the other hand, mites were found to be very plentiful in the tips of the injured trees in a number of instances, and the conviction was expressed that the trouble was due to them. Experimental evidence on this point was obtained by placing around uninjured seedlings in pots the tops of seedlings showing the affection, with the result that the 
uninjured seedlings soon became injured in the same way, yet no thrips were observed on these plants.

\section{ECONOMIC IMPORTANCE.}

Concerning losses in Maryland, Mr. Johnson, in the Entomological News, ${ }^{1}$ states that over 125,000 trees were rendered worthless during 1896 and 1897; and, writing in $1900,{ }^{2}$ he affirms that the injury still continues about as previously reported, causing dwarfed, crooked, and unsalable trees, and adds:

The extent of the damage, however, this year is not so great as last, as the mite did not appear until after the young trees had made from 2 to 3 feet of growth, while last season the most injury was done when the trees were from 10 inches to 1 foot in height. As a result, a much larger proportion of trees this season are salable. The mites are still active and ruining terminals in many places. On the 9 th instant $I$ found eggs of this species behind injured buds in the cavities occupied.

Dr. John B. Smith states (loc. cit.) in reference to New Jersey that in almost all of the nurseries which he visited during 1899, a large percentage of the trees showed this affection, and, as already noted, Prof. W. B. Alwood in a letter to Dr. Smith also refers to the prevalence of the trouble in Virginia, as noted by him since 1891.

Concerning the extent of injury in Virginia Mr. Phillips states (loc. cit., p. 52):

No peach trees had formerly been gromn in the soil where these observations mere made prior to 1903. In that year a large block of peach was grown on one section of the farm, about 400 yards distant from the block under discussion.

The plants grew very rapidly at this place, and were from $1 \frac{1}{2}$ to 2 feet high on the 17 th of May, at the time this examination was made. In the 8,500 plants examined the injury varied from 10 to 20 per cent, depending upon the local conditions. It was much worse in the slight depressions where water stood for a while after heavy rains.

At this time (May 17), however, the injury had just begun to show plainly. Later in the season it was found that not more than 20 to 30 per cent of the trees had escaped injury in many sections of the field. Less than 20 per cent of the trees were injured in some sections which were located mainly at points where the drainage was good.

A large block of seedling peach, standing about one-half to three-fourths of a mile from the budded stock, and just across the fence from the land that grew peach the year before, was examined June 22. In the section of seedlings nearest to land that stood in peach the previous year (just across the fence) 28 per cent of the plants had been attacked at this date. At another point, about 300 feet from the land that was in peach the previous year, but on a slight knoll where the soil was a little drier, only 14 per cent of the plants were attacked; but in a lower place, about 900 feet distant, 30 per cent of the plants were injured.

At this date (June 22) about 80 per cent of the budded peach had been injured by this trouble in many sections of the field, a much larger percentage than was injured in the seedlings; but as the seedlings were grown and budded on the land the previous year, it is but natural to suppose the injury would be worse in the budded stock. 
Data in regard to height at which injury occurred on the trees.

\begin{tabular}{|c|c|c|c|c|}
\hline $\begin{array}{c}\text { Number of } \\
\text { trees in } \\
\text { row. }\end{array}$ & $\begin{array}{c}\text { Number } \\
\text { uninjured. }\end{array}$ & $\begin{array}{l}\text { Number } \\
\text { injured } \\
\text { within } 2 \frac{1}{2} \\
\text { feet of the } \\
\text { ground. }\end{array}$ & $\begin{array}{l}\text { Number } \\
\text { injured } \\
\text { between } 2 \frac{1}{2} \\
\text { and } 4 \text { feet } \\
\text { above the } \\
\text { ground. }\end{array}$ & $\begin{array}{l}\text { Number } \\
\text { injured } \\
\text { above } \\
4 \text { feet from } \\
\text { ground. }\end{array}$ \\
\hline $\begin{array}{r}182 \\
43 \\
119 \\
161 \\
225 \\
194 \\
176\end{array}$ & $\begin{array}{r}25 \\
9 \\
04 \\
109 \\
180 \\
123 \\
94\end{array}$ & $\begin{array}{r}25 \\
5 \\
9 \\
6 \\
13 \\
9 \\
14\end{array}$ & $\begin{array}{r}41 \\
129 \\
34 \\
26 \\
24 \\
39 \\
39\end{array}$ & $\begin{array}{r}21 \\
12 \\
20 \\
8 \\
23 \\
29\end{array}$ \\
\hline
\end{tabular}

1 In this case nว distinction was made between those injured at this height and those injured at above 4 feet from the ground.

When the writer examined the nursery, on May 17, quite a number of the trees had already been injured, and the indications are that it began about May 12. The injury occurred at an almost uniform height on the trees for three periods: First, from 1 to 2 feet high, about May 12; second, from $2 \frac{1}{2}$ to $3 \frac{1}{2}$ feet high, about June 12; third, about 4 feet high. The percentage of trees injured increased with each period, indicating that there must have been several successive broods of the form causing the trouble.

The dividing line between the number injured at $2 \frac{1}{2}$ to 4 and above 4 feet was not gauged properly in the latter part of the table; hence the figures in the first line should be considered as much more nearly correct than the others.

Occasional complaints concerning this "stop-back" disease have been received by the Bureau of Entomology during the past several years. Specimens of injured peach trees from a nursery company near York, Pa., were received in 1905, and the damage done was stated to be heavy. During the spring of 1906 a Delaware nurseryman complained of serious loss to peach stock, estimating for the previous season a loss of about $\$ 2,000$. The writer visited this nursery in June of the above year, and found the trouble quite prevalent, though, as stated by the owner, not so serious as the year before. In a large nursery in Maryland during the same year the work of the mite was in evidence, occurring quite generally over a large block of budded trees, though not especially serious.

Complaint of this affection in a large nursery near Philadelphia was received July 27, 1911, through Prof. H. R. Fulton, State College, Pa., with specimens of injured plants. It was stated that there had been a considerable amount of the trouble that year as well as a slight amount the year previous. Mr. J. F. Zimmer, of the writer's office force, visited this nursery August 24-25, and in conference with the owners it was learned that the injury during the year 1911 was estimated at about $\$ 15,000$. This nursery was later visited by the writer and the injury was found to be quite serious, as stated, involving a portion of the large block of budded trees, and a small area of injured trees was found in a seedling block. The mite was found in some numbers working on peach, and a few 
examples were noted by Mr. Zimmer on an adjoining block of apple of the Jersey Sweet and Early Harrest varieties. The varieties of peach most injured were Crawford's Late, Mountain Rose, and Old Mixon. The varieties Crosby, Stump the World, and Georgia Bell were least injured. The ground planted had been in wheat in 1909 and was planted to peach for the first time in the spring of 1910. The buds used were obtained partly from a bearing orchard, but largely from nursery trees in an adjacent block, but in which no injury had been noted.

A similar outbreak was also reported as occurring in a near-by nursery.

A prominent nursery company in Ohio, writing of this trouble, states, under date of October 30, 1911:

Te have been bothered with the thrips in peach trees for 15 or 20 years. This year and last very bad. Some years rery little. This year first time ever bothered much on peach seedlings. If we can get peach buds 3 or 4 feet before this pest begins, we can make very good trees.

A Maryland nursery firm gives their experience as follows, under date of October 24, 1911:

Te have had lots of trouble and loss caused by the "setback" on peach seedlings and also on peach buds. In 1910 we saw no signs of it, but this year (1911) it caused us a good deal of extra expense. Then the trees are stung by this insect in the terminal bud during the summer and when the trees are about 18 to 24 inches tall, it causes them to stop growing in the top and put out a lot of side or lateral branches, and if not attended to they will be worthless. The past summer we kept a gang of men going over our peach blocks and cutting or heading in the side branches in order to throw the growth to the terminal and make them start a second growth. In this way by constant work we got our trees to start to grow and the most of them finally outgrew the trouble. Te knew no other remedy than to cut the side branches back 2 or 3 inches. We notice it is much worse in some places even in the same field than others.

Prof. Waite's careful observations, and those of Messrs. Johnson, Phillips, and others, indicate clearly that the Tarsonemus waitei is the cause of the so-called "stop-back" affection of peach nursery stock. It may also be true that injury practically identical in effect on the trees is caused by thrips, as stated by Dr. Smith and Prof. Alwood. Young thrips larvæ, principally Euthrips tritici, are very commonly found in the tender growing tips of various kinds of regetation, and are especially common in peach nursery trees. In blocks of trees infested with the mite, the thrips larvæ have been found by the writer in great abundance, but never, so far as could be determined, killing the tips of the shoots. The writer is inclined to the belief that the injury in Ohio, New Jersey, and Virginia (as shown by Phillips) is due to the Tarsonemus, its small size, agility, and habits contributing to its oversight.

Any injury to the growing tip of a peach shoot, as by plant-bugs, would naturally produce a similar effect in causing the cessation of growth and the development of lateral shoots, but the comparative 
Plate XIII.

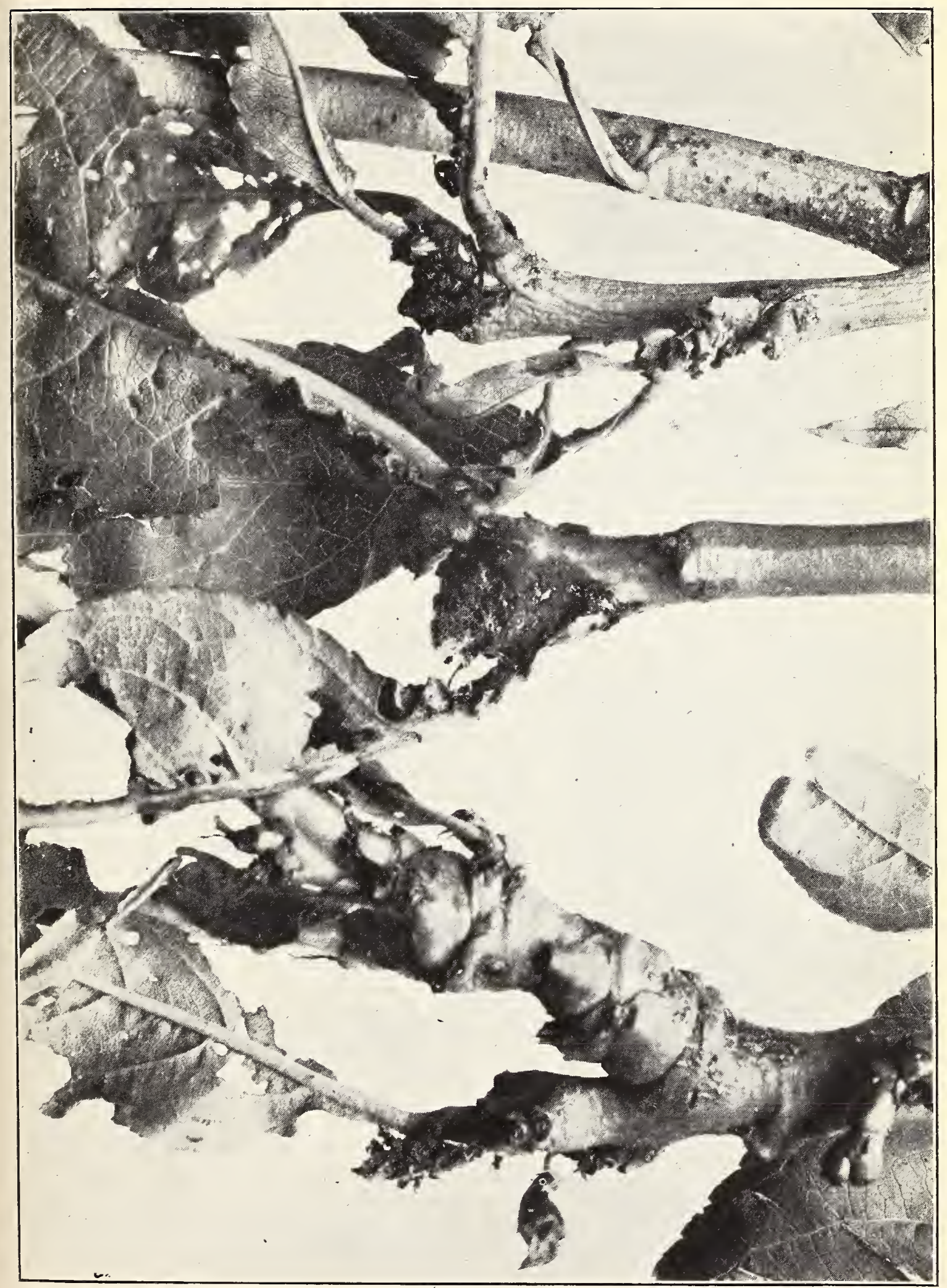

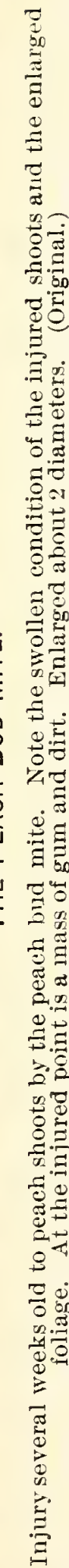



scarcity of such insects in injured blocks in the territory under consideration does not warrant their association with the trouble.

During the growing season the mites are to be found here and there on the plants behind the buds, or in cavities and places offering protection, and one or more may usually be found at the injured tip under ar adjacent bud or more or less covered by the mass of exuded gum. Injury consists in the puncturing of the tender shoot near the tip, which soon wilts, falls over, and turns brown and dry.

At the injured point gum soon exudes, and the cessation of further growth of the shoot results in its swelling out and in a notable increase in the size of the adjacent leaves, which assume a deep glossy green color. Lateral shoots soon push out, the number and position varying widely, resulting in a crooked or bushy topped tree of but little market value. As stated by one nurseryman, many of the inserted buds which set normally, and were noted to be green and in healthy condition during the fall, winter, and spring, died before starting, or the shoot put out and died soon afterwards. The writer has observed a good deal of this kind of injury, especially where the work of the mites on the trees was later most in evidence, and this injury to the dormant bud may also result from the mites.

The characteristic injury some ten days or two weeks old is shown in Plate XII, somewhat enlarged. It will be noted that the point of injury is adjacent in each case to a leaf, where the mite probably sought protection. 'The tips of the shoot above the point injured had fallen over and were brown and dry, and in two of the examples the accompanying exudation of gum may be detected.

Some weeks later the injured shoots have the appearance shown in Plate XIII, about twice enlarged. The stem has filled out and there is a considerable mass of blackened gum and dirt on the tip of the injured stem. In the example on the right, a strong lateral shoot has developed. The large, congested leaves are also shown.

On Plates XIV and XV is shown the appearance, in the fall, of trees injured by the mite. As will be seen, the plants, except in one instance, were cut off just below the bud. Most of the specimens show two distinct attacks by the mite, with consequent formation of lateral branches.

As before mentioned, the peach bud mite, in the opinion of one nurseryman-and a careful observer-is responsible for the killing of the bud inserted in the seedling, as it is starting growth in the spring, or after the shoot has pushed out. Plate XVI shows, considerably enlarged, buds injured in this supposed manner.

In some cases the attack of the mite does not cause the death of the shoot, which continues to grow, but at the injured place there develops a characteristic rusty scar of variable size and shape, which in vigorous growing trees may become a long, rusty streak, extending 
between the nodes. Smaller rusty scars or pits are often found under the buds occupied by the mites and undoubtedly result from the puncturing of the tender tissue.

The mite infests both seedlings and budded trees and is also common in orchards. The injury to seedlings, which as a rule are budded. below the point from which the laterals in most cases develop, is much less important than the injury to the budded stock the season following. Injury in orchards has not thus far been observed to be serious, but the mites are usually common and might be readily introduced in nurseries with budding-wood.

\section{HABITS AND NATURAL HISTORY.}

But few observations have been made on the habits of the peach bud mite and further information is very desirable for a proper application of control measures. According to Prof. Waite, as detailed to the writer in conversation, the mites hibernate on the plants behind the bud scales. It is especially important to know if the mite winters exclusively on the dormant nursery trees and if it has other important food plants than the peach. The writer examined in March, 1906, a lot of dormant peach stock from an infested nursery, including several trees badly injured, and only one mite was found hidden in a small cavity in the stem near the base of the tree. December 15, 1911, a lot of 36 1-year peach trees badly injured by the mite were carefully examined, and while two specimens of a gamasid mite were found, no specimens of the peach bud mite were discovered.

The mites appear on the trees quite early in the spring, and by the time the shoots are 18 or 20 inches in height, their injury is much in evidence. As stated by Mr. Phillips for tidewater Virginia, the injury has begun to show plainly by May 17, at which time 10 to 20 per cent of the trees already showed more or less symptoms of attack. Mr. Phillips believed that the injury began as early as May 12, and presents a table showing the proportion of trees injured at different heights from the ground, as already quoted (p. 107). In a Delaware nursery, injury was very common by June 6 , the attack beginning apparently two or three weeks earlier. Dr. Smith, speaking of thrips injury in New Jersey, states that it was quite common by June 8, at which date almost 50 per cent of the shoots in nurseries examined had the terminals killed. It is evident, therefore, that the mite begins operations during the latter part of May. Mr. Phillips's observations indicate three different periods of principal injury, which he considers mark as many generations of the mite.

Breeding probably occurs largely on the trees. Mr. Johnson records finding eggs of the mite in cavities behind the injured buds. The writer on different occasions has found the mites of various sizes behind buds, indicating that they had there developed. 


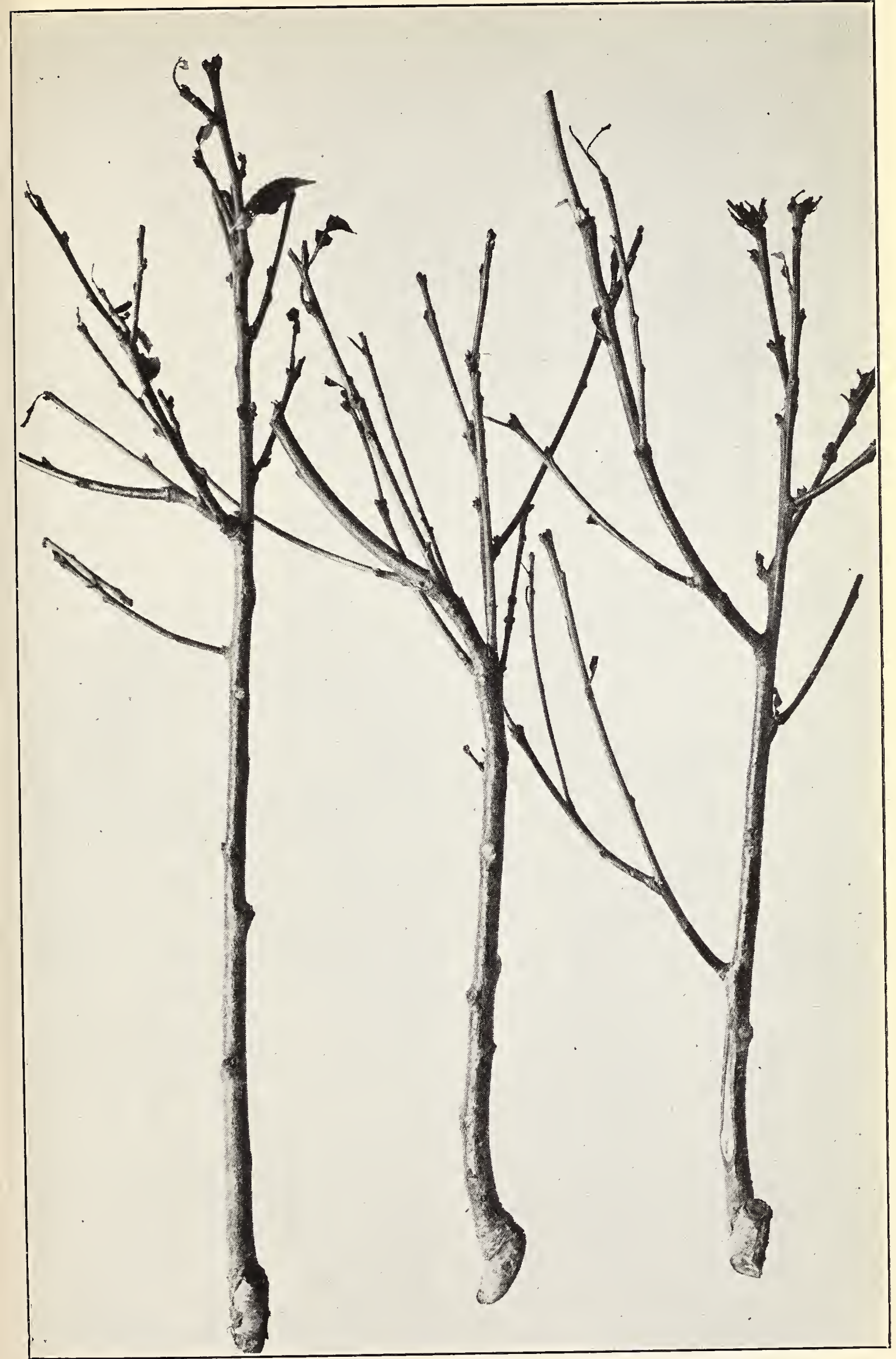

The Peach Bud Mite.

The condition of peach nursery trees in the fall, due to injury by the peach bud mite. (Original.) 



\section{SYSTEMATIC RELATIONSHIPS AND OTHER ECONOMIC SPECIES.}

According to Banks ${ }^{1}$ the family Tarsonemidx is a small one of much biological and economic importance. There are two subfamilies, Pediculoidinæ and Tarsoneminæ. These soft-bodied mites resemble also the Tyroglyphidx, though the females differ from these and all other mites in the presence between the legs (pairs 1 and 2 ) of a prominent clavate organ of uncertain use. Concerning the systematic position of the family there has been considerable doubt among the students of the Acarina and it has not long held any one position. It has been as̃sociated with the Oribatidæ and the Cheyletidæ, and, according to Berlese, the family constitutes one of the principal groups of the order.

The subfamily Tarsoneminæ includes but two genera, the species differing from those of the other subfamily in that the hind leg of the female ends in a long hair. The two genera, Disparipes and Tarsonemus, are represented by a considerable number of species, and many species of Tarsonemus are of distinct economic importance. Tarsonemus oryzæx Targ.-Toz. infests the culms of the rice plant in Italy, ${ }^{2}$ and produces the malady described by Negri under the name "bianchella" (bleaching), which is particularly characterized by the presence of numerous very fine threads or fibers thought to be produced by this acarid; this thread-spinning habit is not found, apparently, associated with any other species of the genus thus far known.

An affection of oats in France and Germany caused by Tarsonemus spirifex March. has recently been well treated by Dr. Paul Marchal and others. ${ }^{3} \quad$ The mites inhabit the sheath surrounding the head or panicle of the oat plant, preventing proper development, and causing the stem to assume a distorted spiral shape, which may push out along the side. In other cases the distorted stem is held inclosed in the sheath, which becomes fusiform, and these plants are called "avoines en cigares." The mites appear early in June and the characteristic spirals during the second fortnight of the same month; all stages, as the egg, larva, and both sexes of the adult being found together on the plant. It is not known how this mite passes the winter. Marchal suggests the possibility that it may hibernate in a very resistant condition in the soil, though evidence to the contrary is cited as obtained by M. Guille, who considers it probable that the mites migrate in the fall to adjacent wild grasses. The mite also lives in wheat, barley, and rye, though oats is the preferred food. Excessive dry weather is regarded as favorable to its development.

1 Proc. U. S. Nat. Museum, vol. 28, p. 74, 1893.

2 La mallatia della bianchella del riso cultivato. Casale, 1873.

3 L'Acariose des avoines. Annales de l'Institut National Agronomique, 2d ser., tome 6, fase. 1er, $190 \%$. 
Tarsonemus ananas Tryon was determined by Tryon to be the primary cause of a disease of pineapples in southern Queensland. The mite infests the pineapple plant quite generally, as the stem of the fruit, deep between the bases of the leafy bracts, forming the tuft at top of plant, and especially the fruitlets, where, by its puncturing with its styliform mandibles at the base of the carity containing the essential organs, an injury is produced which may be followed by the invasion of a fungus, resulting in the so-called "fruitlet core rot." The mites are never very abundant and shun the light, inhabiting principally the deeper recesses of the fruit.

Two species of Tarsonemus have been reported by Mr. A. D. Michael as injuring sugar cane in Barbados. ${ }^{2}$ One species, which he calls Tarsonemus bancrofti Michael, also occurs in sugar cane in Queensland. The mites were exceedingly abundant in all stages on the canes observed by Mr. Michael, living principally under the leaf sheaths. They are thought to be present in other sugar-producing countries, but have thus far escaped notice. The infestation of cane by mites, according to Mr. Bovell, superintendent of Dodds Botanical Garden, reduces the annual yield of sugar from 3 tons to 1 ton per acre.

Another mite, Tarsonemus culmicolus Reuter, produces a silver-top disease of grasses in Finland, ${ }^{3}$ occurring especially on Phleum, pratense, Agropyron repens, and Festuca rubra. This species has been well treated by Dr. Enzio Reuter. The mites are present on the grasses from early spring to fall, infesting the interior of the leaf-sheath, living on the tender stem above the highest node. While no deformity results, the extraction of the juice occasions the drying up and death of the inflorescence, which remains filiform and turns white.

Tarsonemus latus Banks was found by Banks in some small mango plants in one of the department greenhouses in Washington. ${ }^{4}$ Some plants had stopped growth, and the mites occurred principally on the swollen and partially discolored tips.

Tarsonemus pallidus Banks was found on a chrysanthemum in a greenhouse near Jamaica Plain, N. Y.5

There are numerous other species, but those cited will serve to show the importance from an economic standpoint of this group of small creatures, and adds additional evidence, by reason of its relationship, that our peach bud mite is responsible for the injury to peach herein described.

\footnotetext{
1 Fruitlet core rot of pineapples. Queensland Agr. Journ., 1898, p. 458.

2 Report on diseased sugar cane from Barbados, etc. Bull. Royal Gardens, Kew, 1890, p. \$5.

3 Üher die Weissährigkeit der W iesengräser in Finland. Acta Soc. pro Fauna et Flora Fennica, vol. 19, No. 1, 1900, p. 77.

4 Journ. N. Y. Ent. Soc., vol. 12, 1904, p. 55.

5 Proc. Ent. Soc. Wash., vol. 4, 1898, p. 294.
} 


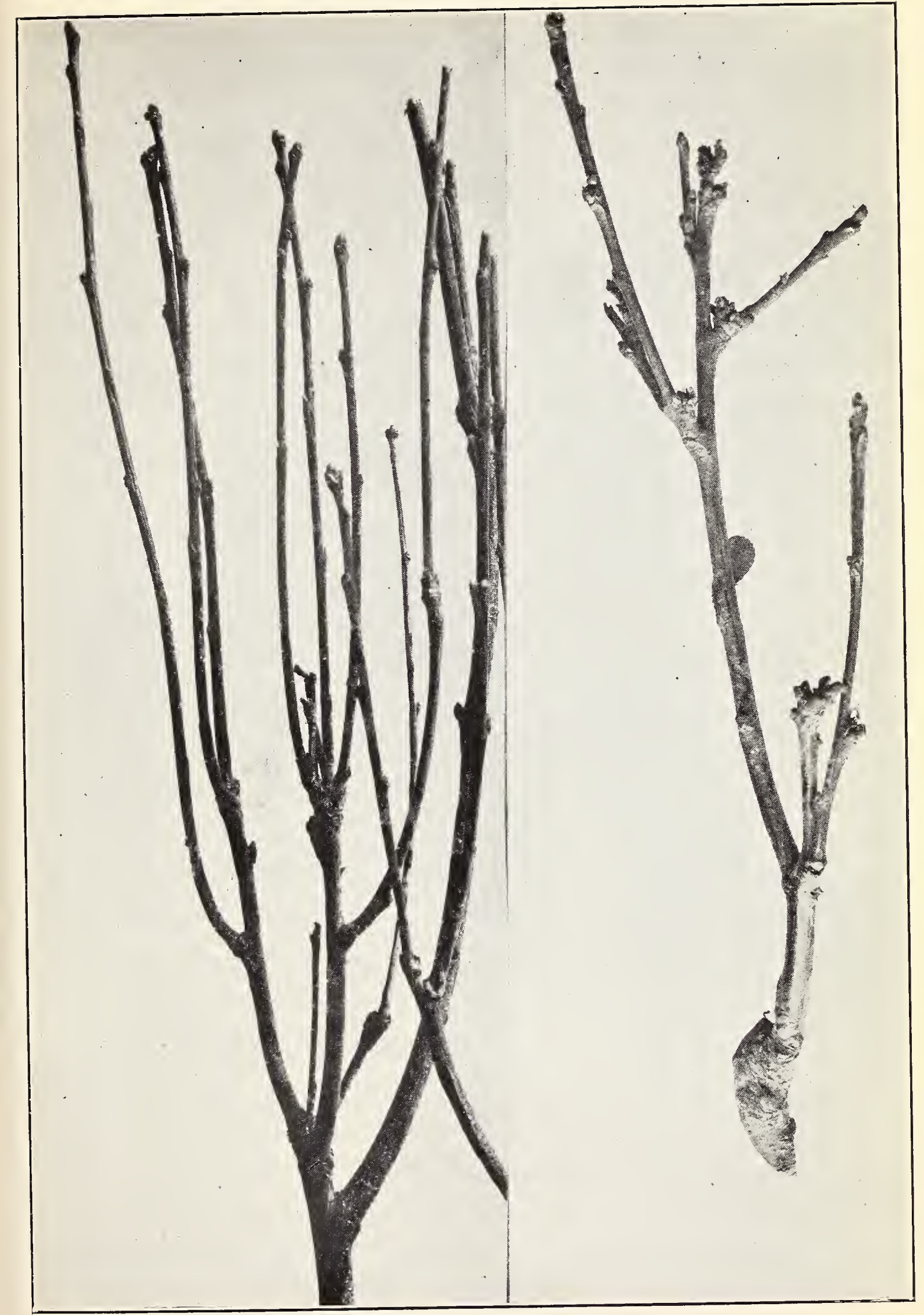

The Peach Bud Mite.

The condition of peach nursery trees in the fall, due to injury by the peach bud mite. The specimen on the right is not over 18 inches high, the specimen on the left shows two distinct periods of attack. (Original.) 


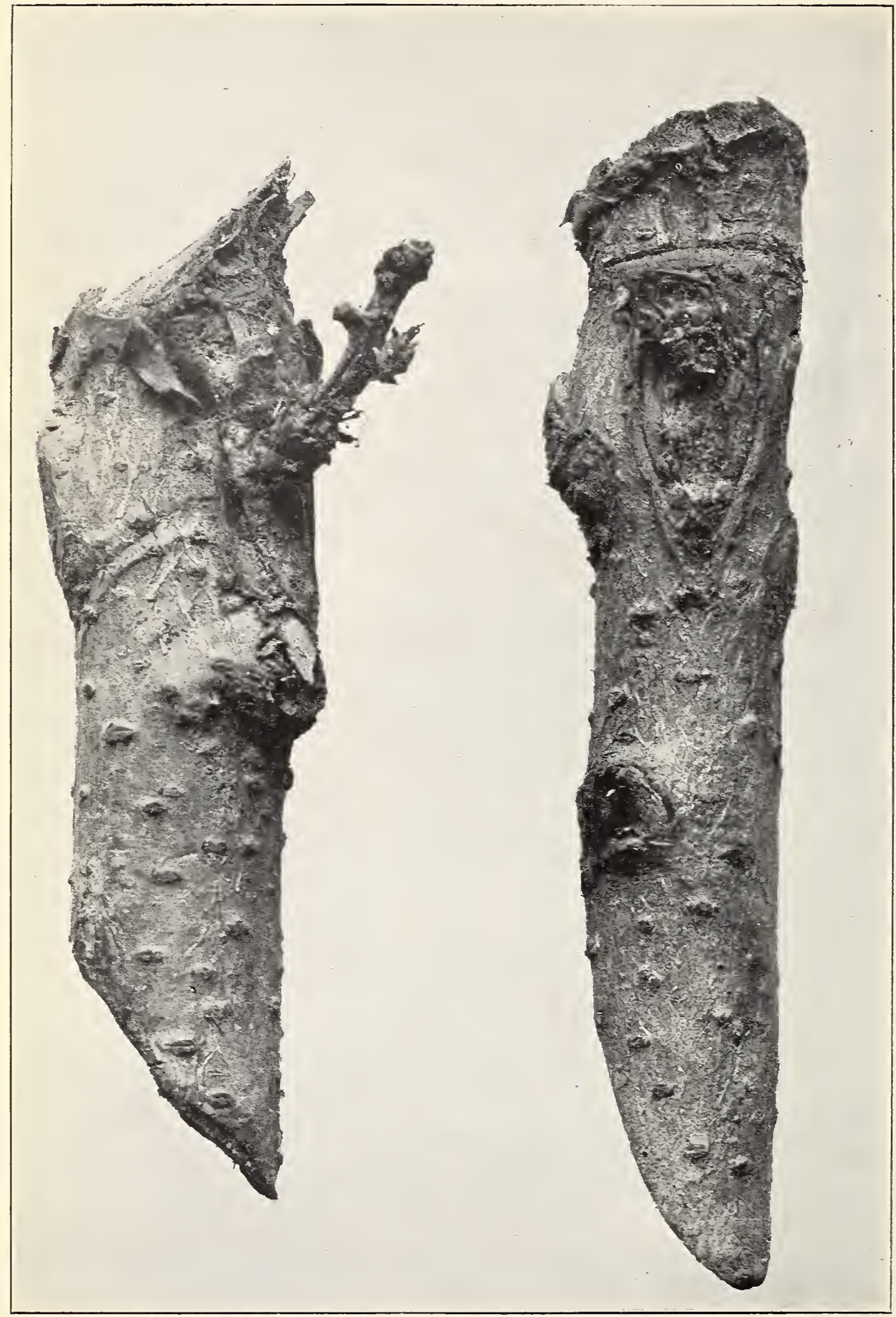

The Peach Bud nilte.

Injury to buds supposedly due to peach bud mite. These dormant buds were green all winter and were killed in the spring as growth commenced. Enlarged. (Original.) 


\section{REMEDIAL CONSIDERATIONS.}

There is but little information available bearing on the control of the peach bud mite. Prof. Waite, in conversation, informed the writer that when the trouble was present several years ago in his nurseries, he was able to prevent injury by thoroughly spraying, during the dormant season, the trees subject to injury with lime-sulphur wash. It was not learned, however, whether trees were left untreated for purposes of comparison. The known effectiveness of sulphur, dry or in soluble compounds, against mites in general is ground for the belief that sulphur sprays would be effective in this case. It is uncertain, however, whether the mites winter exclusively on the peach nursery stock. The value of dormant treatments would depend upon the extent to which the mites hibernate on the trees. There is some evidence that they hibernate elsewhere. In the instance of serious injury in the Delaware nursery, earlier mentioned, all of the block of peach stock, save one row, was sprayed with lime-sulphur wash during the spring of 1906 (dormant buds). Examinations by the writer during the following summer did not show any difference between the sprayed and unsprayed trees, and the infestation was uniformly quite prevalent.

It has been the practice for some years of one large nursery firm to spray blocks of their peach trees during the dormant period with a miscible oil used at full winter strength. Notwithstanding this practice the trees have been seriously injured by the mite, and in one large block thus sprayed during the dormant period of the spring of 1910 the mite was especially prevalent in one portion during the summer of 1911. These results suggest that the mites also winter in other places than on the peach trees.

In the experience of Mr. Phillips, already quoted, (p. 106), considerable benefit resulted from prompt attention to pruning the injured plants, so as to correct the trouble as much as possible, by the selection and forcing of one of the best lateral shoots. He treats this question at some length (loc. cit.) and his table of results from pruning tests is herewith quoted:

Data in regard to pruning peach trees in the nursery affected by "stop-back."

\begin{tabular}{|c|c|c|c|c|c|c|}
\hline Tarieties. & $\begin{array}{l}\text { Total } \\
\text { number } \\
\text { of trees } \\
\text { in row. }\end{array}$ & $\begin{array}{l}\text { Number } \\
\text { injured } \\
\text { by } \\
\text { May } 18 .\end{array}$ & $\begin{array}{l}\text { Number } \\
\text { pruned } \\
\text { May } 18 .\end{array}$ & $\begin{array}{c}\text { Number } \\
\text { of crooked } \\
\text { tre€s } \\
\text { Aug. } 15 .\end{array}$ & $\begin{array}{l}\text { Number of } \\
\text { injured } \\
\text { trees that } \\
\text { grew up } \\
\text { straight. }\end{array}$ & $\begin{array}{l}\text { Percentage } \\
\text { of pruned } \\
\text { trees that } \\
\text { grew up } \\
\text { straight. }\end{array}$ \\
\hline $\begin{array}{r}\text { Yonderful. } \\
\text { Champion. } \\
\text { do...... } \\
\text { (?) } \ldots . . .\end{array}$ & $\begin{array}{r}1,259 \\
1,010 \\
1,130 \\
160\end{array}$ & $\begin{array}{l}147 \\
150 \\
133 \\
225\end{array}$ & $\begin{array}{r}147 \\
150 \\
\text { Check. } \\
225\end{array}$ & $\begin{array}{r}46 \\
49 \\
1119 \\
3\end{array}$ & $\begin{array}{c}101 \\
110 \\
-\ldots \\
22\end{array}$ & $\begin{array}{r}68 \\
73 \\
- \\
88\end{array}$ \\
\hline
\end{tabular}

I Some time after this row was decided upon as a check, it was learned that one of the laborers had pinched a number of trees at one end. This accounts for there being fewer crooked trees than had been injured May 18.

2 June 22. 
In this article Mr. Phillips concludes:

We were not able to give enough time to the work to have the trees pruned more than once, but the success of this pruning indicates that the trouble can be prevented almost entirely by judicious pruning. Indiscriminate pruning, by an ordinary laborer, is not, however, likely to produce beneficial results.

This work costs but very little in excess of the regular pruning, as both can be done at the same time.

The first pruning should be done about the middle of June.

In order to make it entirely effective, a second pruning should be given a few weeks aiter the first.

Where this attack occurs in peach trees that are not growing rapidly, the pruning should be supplemented by a dressing of nitrate of soda to promote growth.

Good drainage will likely prevent the trouble in a large measure.

As stated on page 108, pruning out the laterals from the injured trees, thus forcing one of the more terminal shoots, was followed the past season by a Maryland nursery company with good results. The pruning method would appear to be of considerable benefit, and to a large extent this special work may be combined with the usual necessary prunings required in growing trees of this kind. In locations where the mites are likely to be troublesome a lookout should be kept for their injury to the plants in the spring. The tips of the lateral shoots should be pinched off, except the first strong lateral below the injured point, which it is desired to force ahead as much as possible.

A thorough application of a suitable spray to the infested trees, especially during the period of attack in late spring, should be of decided value, though the writer knows of no actual work of this kind having been done. At this time the mites are on the trees in numbers, and by thorough spraying many of them should be killed. A contact spray such as kerosene emulsion or whale-oil-soap solution should be effective, and especially the self-boiled lime-sulphur wash. Most observers agree that the mite is more prevalent on trees on low situations. While the writer has noted exceptions to this condition, it seems for the most part to be true. Planting trees on higher situations where the soil is well drained would perhaps be advantageous in localities where the mite has come to be quite troublesome. 


\title{
PAPERS ON DECIDUOUS FRUIT INSECTS AND INSECTICIDES.
}

\author{
THE GRAPE SCALE. \\ (Aspidiotus [Diaspidiotus] uvæ Comst.) \\ By James F. Zimmer, \\ Entomological Assistant.
}

\section{INTRODUCTION.}

The grape scale, Aspidiotus (Diaspidiotus) uvæ Comstock, has been reported as more or less destructive to grapevines during the last three decades. The insect occurs, to a very limited extent, on certain forest and shade trees, tnough the records do not show serious injury to plants other than the grape.

Apparently the earliest record of this species is to be found in the notes of the Bureau of Entomology. Under date of November 12, 1875, from St. Louis, Mo., Mr. Theodore Pergande forwarded specimens of the grape scale to the Entomologist of the Department of Agriculture. This insect was later found at Vevay, Ind., as stated by Prof. F. M. Webster, ${ }^{1}$ by Mr. C. G. Boerner, though no date is given. This material was used by Prof. Comstock in the preparation of the original description of the species which appeared in the Report of the Commissioner of Agriculture for the year 1880, pages 309-310.

\section{DISTRIBUTION AND FOOD PLANTS.}

In addition to the records above cited, the grape scale was received from Miss Mary E. Murtfeldt, Kirkwood, Mo., in 1888, and it was stated that grape canes in that vicinity were very badly infested with the insect. Two years later specimens of the grape scale were received from Prof. F. M. Webster at Lafayette, Ind., with a similar report as to its occurrence.

In October, 1897, Mr. F. Noack reported the grape scale in vineyards in the vicinity of São Paulo, Brazil, and in January, 1900, the grape scale was reported on sycamore, from Atlanta, Ga., by Mr. W. M. Scott.

This scale was also found on sycamore by Mr. James G. Sanders, at Columbus, Ohio, in 1902, and was reported from Gentry, Ark., on grape by Mr. E. L. Jenne, of this bureau, in 1900. Many other reports 
have been noted and the list of host plants found thus far is as follows: Ampelopsis sp., Carya alba, Carya sp., cultivated grape, Platanus occidentalis, Platanus sp., European grape (Titis vinifera), and wild grapes (Titis spp.).

The records do not show that there is variation among the different varieties of grapes as to susceptibility to attack, but it is likely that the strong'er-growing sorts would be least injured. So far as known the grape scale is of no economic importance, except on the grape, but it has been the subject of frequent complaint on grapes during the past few years and in certain vineyards in the environs of Washington its injuries have become decidedly important, requiring treatment for the preservation of the vines.

From the above it will be seen that the grape scale is rather widely distributed in the eastern United States, occurring from Florida north to New Jersey and as far west as Missouri. From published records and those in the Bureau of Entomology, it is known to occur in the following States: Alabama, Arkansas, Delaware, District of Columbia, Florida, Georgia, Illinois, Indiana, Kansas, Kentucky, Maryland, Mississippi, Missouri, New Jerser, North Carolina, Ohio, Tennessee, Virginia, and West Virginia. It has also been reported from foreign countries, being listed from many parts of Europe, from Brazil, Jamaica, and the West Indies.

\section{HABITS AND NATURAL HISTORY.}

Grapevines, when badly infested with the grape scale, have the appearance of being coated with a profuse, dingy white scurf. (See Pl. XVII.) The scales occur upon the canes, protected by the shreds of the exfoliated bark tissue of the previous season's growth. From observations made, this insect seems to have many habits similar to those of the San Jose scale (Aspidiotus perniciosus Comst.). The grape scale, when abundant, very materially retards the development of the vines and alwars infests the second year's growth. The young "lice" hare the peculiar habit of settling in rows. (See Pl. XVIII, fig. 1.) Frequently the canes are so thickly infested that they have the appearance of having been treated with a heary coat of whitewash. The insect apparently does not spread readily, as it has often been noted that while one vine in a row may be badly infested, not a single scale is to be found on adjacent plants.

The female insect, during the months of May and June, gires birth to from 35 to 50 living young. After a brief active stage of about two days, the young "lice" settle down on the cane and there is a fairly uniform development. During the period of growth from the immature larra to the adult stage, the insect molts or casts its skin twice. As is true with all of the armored scales, the life of this insect, with the exception of the short period of activity of the young, 


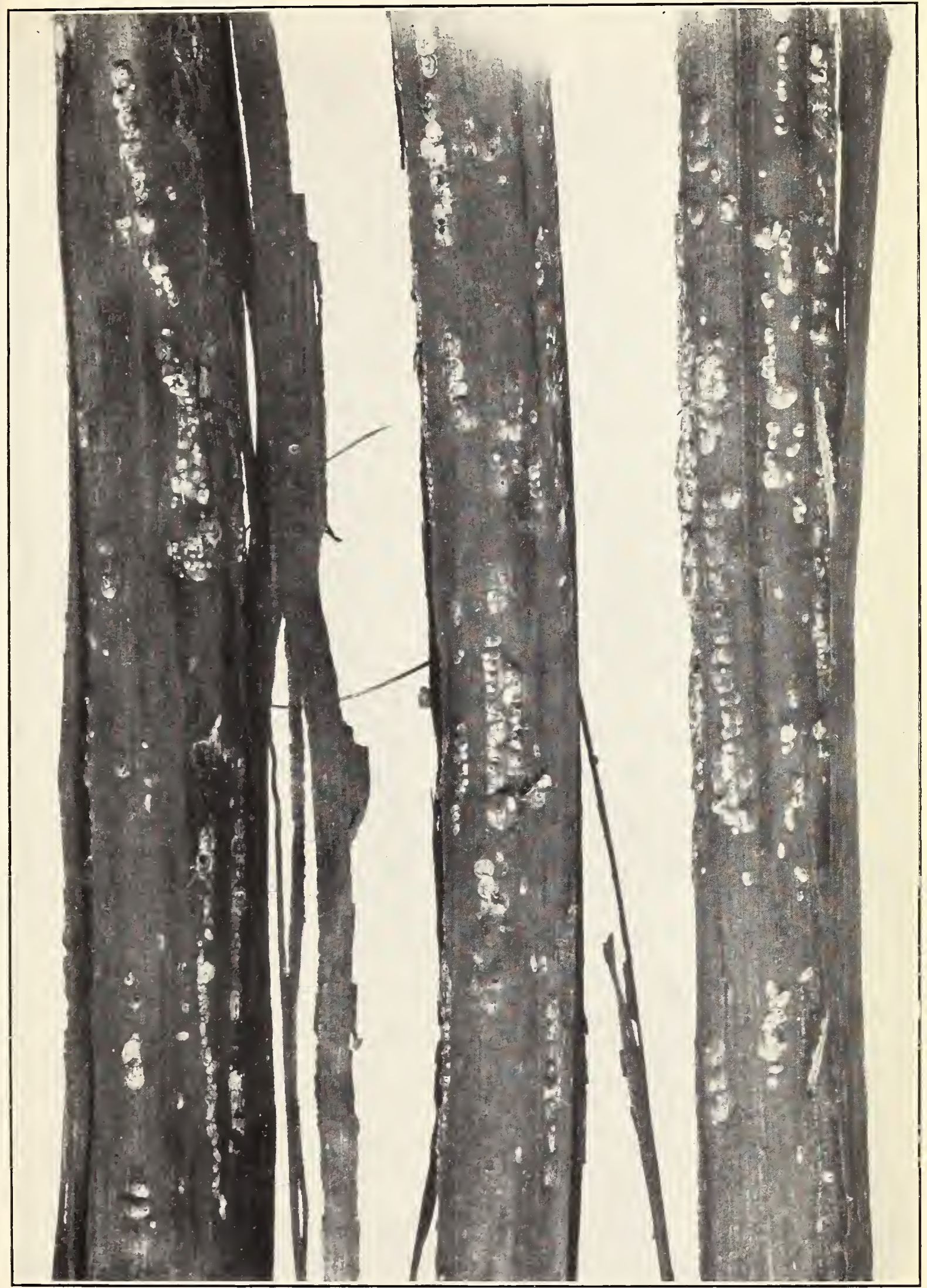

Grape Canes, Enlarged, Showing Infestation by the Grape Scale, Aspidiotus (DIASPIDIOTUS) UVAE.

Note how the scales occur in rows on the canes. (Original.) 


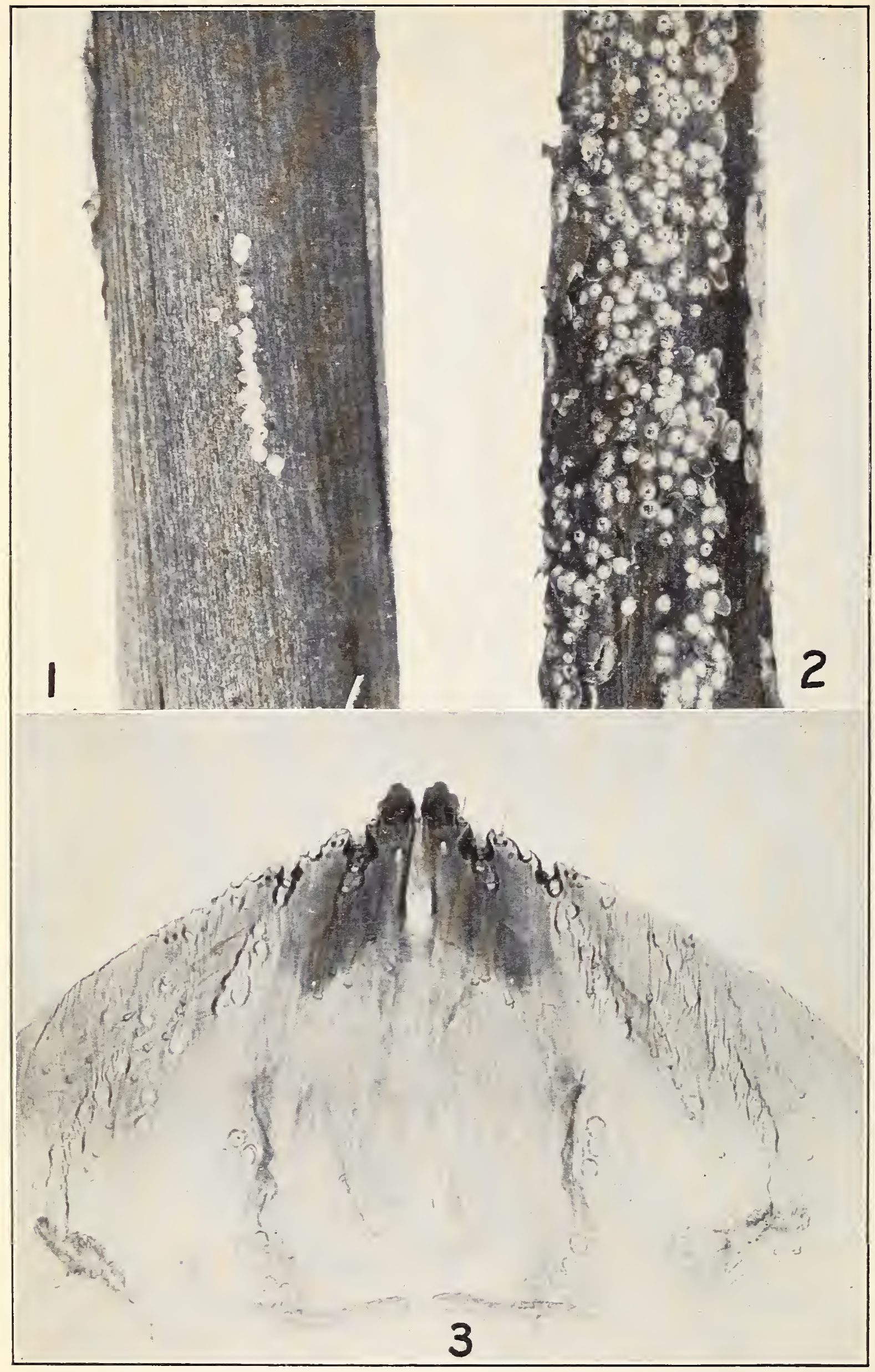

THE GRAPE Scale.

Fig. 1.-Showing how the young scales settle, more or less, in longitudinal rows. Fig. 2.-Fullgrown male and female scaies; also many parasitized individuals. Fig. 3.-Pygidium of adult female, showing circumgenital glands and orifice, lobes, and spines. (Original.) 
and an equally brief period of activity of the winged male, is passed under the protection of a waxy covering, closely applied to the host plant. The female is wingless throughout her life. The adult winged male appears in June. The winter is passed by the insects in a nearly full grown condition. Our observations show that there is only a single brood of larvæ each year. It also appears that this species does not deposit eggs, as has been thought, but that the female is viviparous.

Some newly born. larvæ (fig; 26) were placed on a grape cane in order to ascertain the length of the active stage. The crawling "lice" were kept under occasional observation and at the end of 24 hours all were still moving, but after 48 hours all lice had settled down and had already begun the excretion of the white waxy covering. The scale formed over the young insect is whitish in color and appears to have two rings on its dorsal surface. The edge of the scale is closely cemented to the bark of the twig.

Many larvæ were examined to ascertain how fully the lobes were developed. When one day old, well-developed median lobes were found to be present.

\section{DESCRIPTION. ${ }^{1}$}

Scale of female (PI. XVIII, fig. 2).-Xellowishbrown, slightly lighter than the bark of the vine, diameter 1.1 to $1.7 \mathrm{~mm}$., circular and comparatively flat, exuviæ bright yellow, subcentral.

Scale of male (Pl. XVIII, fig. 2).-Elongate, length 0.9 to $1.0 \mathrm{~mm}$., width $0.5 \mathrm{~mm}$., exuviæ to one side, slightly darker and more convex than female scale. Adult female (Pl. XVIII, fig. 3). -From 1 to $1.4 \mathrm{~mm}$. in length, oval. Anal plate $0.4 \mathrm{~mm}$. broad at base by $0.23 \mathrm{~mm}$. long. Median lobes prominent, more or less parallel, slightly diverging at tip, notched on each margin, with inner notch fairly prominent and slightly elevated; lateral lobes wanting or rudimentary, as is the case with ancylus; two distinct lateral incisions present; paraphyses of first incision conspicuous, inner the largest, pear-shaped; paraphyses of second incision much smaller; plates minute, obscure; spines on dorsal surface strongly developed, one on median lobe, one cephalad of each incision, and one halfway to the penultimate segment, ventral spines smaller and lateral of dorsal spines; anal opening small, circular, about two and one-half lobes length from tip of median lobes; paragenitals, median 0-4, anterier laterals 4-9, posterior laterals 3-7; dorsal pores present in three rows, first con- 
sisting of two at first incision, second of eight at second incision, third of five to eight caudad of fourth spine; median and lateral basal thickenings prominent; apical ventral chitinization strongly developed, brown; ventral longitudinal ridges fairly distinct. (See Pl. XVIII, fig. 3.)

Winged male (Pl. XIX).-Appears in June; at least no record of its earlier appearance can be found in literature, and the writer reared no males previous to this date. Head $0.06 \mathrm{~mm}$. long, $0.107 \mathrm{~mm}$. wide, about the same color as the thorax, nearly rectangular in shape, broadening somewhat at base. Eyes brownish in color, located on the side of head near the front. Ocelli two in number, on the upper part of the epicranium, and lighter in color than the compound eyes. Mouth parts apparently absent. Antennæ about same color as thorax, bearing 10 segments, the basal one being short and nearly globose, others nearly uniform in size, with spines or hairs which are longer on the apical segment and absent on the basal. Length of antennal segments: (1) $0.016 \mathrm{~mm}$. , (2) $0.016 \mathrm{~mm}$., (3) $0.049 \mathrm{~mm}$., (4) $0.049 \mathrm{~mm}$., (5) $0.05 \mathrm{~mm}$., (6) $0.066 \mathrm{~mm}$. , (7) $0.049 \mathrm{~mm}$. , (8) $0.032 \mathrm{~mm}$., (9) $0.041 \mathrm{~mm}$. , (10) $0.04 \mathrm{~mm}$. Width of segments: (1) $0.024 \mathrm{~mm} .$, (2) $0.016 \mathrm{~mm}$. , (3) $0.014 \mathrm{~mm}$. , (4) $0.016 \mathrm{~mm}$., (5) 0.018 mm., (6) $0.016 \mathrm{~mm}$. , (7) $0.016 \mathrm{~mm}$., (8) $0.018 \mathrm{~mm}$., (9) $0.018 \mathrm{~mm}$., (10) $0.012 \mathrm{~mm}$. Abdomen eight-segmented, having at the caudal end a long spikelike appendage, termed style or genital spike (see Pl. XIX, fig. 2), about $0.215 \mathrm{~mm}$. long and 0.033 $\mathrm{mm}$. wide at base, tapering to a sharp point grooved below, forming a sheath for the penis, this sheath bearing four hairs or bristles at base, two on the dorsum and two stronger, ventrad. Thorax, general color pale clay-yellow, with edge of the thoracic shield darker, approaching cadmium-yellow; slightly longer than broad, crossed at the central part of dorsum by a heavy pale-brown band about one-half the width of the thorax at point of intersection; cephalic and caudal margins slightly concave, with blunt-shaped ends. Wings, length $0.56 \mathrm{~mm}$., width $0.249 \mathrm{~mm}$., covered with numerous spines, colorless, very narrow at base, bearing two main veins, the costal presenting caudal serrations (see P1. XIX, fig. 4); located on the lateral margin of the metathorax are the "halteres," or "balancers," which hook into the lobes at the base of the wings, giving them additional strength. Legs about the same color as body; coxa very broad, stout, wider at base; trochanter nearly rectangular, stout, not so broad as coxa; femur narrower at proximal extremity, growing broader distad; tibia slender, with hairs near distal end; tarsus rather broad at base, gradually taparing toward claw, also with many hairs at distal end; claw broad at base and curved inward. Measurements of left posterior leg, as follows:

\begin{tabular}{|c|c|c|c|c|c|}
\hline & Width. & Length. & & Width. & Length. \\
\hline $\begin{array}{l}\text { Coxa....... } \\
\text { Trochanter. } \\
\text { Femur..... }\end{array}$ & $\begin{array}{c}M / m . \\
0.03 \\
.011 \\
.03\end{array}$ & $\begin{array}{c}M m . \\
0.046 \\
.01 \\
.092\end{array}$ & $\begin{array}{l}\text { Tibia.... } \\
\text { Tarsus. } \\
\text { Claw... }\end{array}$ & $\begin{array}{c}\mathrm{MIm} . \\
0.023 \\
.019 \\
.003\end{array}$ & $\begin{array}{c}\mathrm{Mrm} . \\
0.08 \\
.061 \\
.007\end{array}$ \\
\hline
\end{tabular}

PARASITES.

SPECIES PREVIOUSLY RECORDED.

In one publication ${ }^{1}$ Miss Mary E. Murtfeldt reports a species of Centrodora as being found parasitizing the grape scale.

In another publication ${ }^{2}$ Miss Murtfeldt mentions that the grape scale is preyed upon by mites belonging to the genus Tyroglyphus.

In 1888 and 1889 Miss Murtfeldt sent in a few specimens of a parasite which proved to belong to the Chalcididæ, subfamily Aphelininæ, 


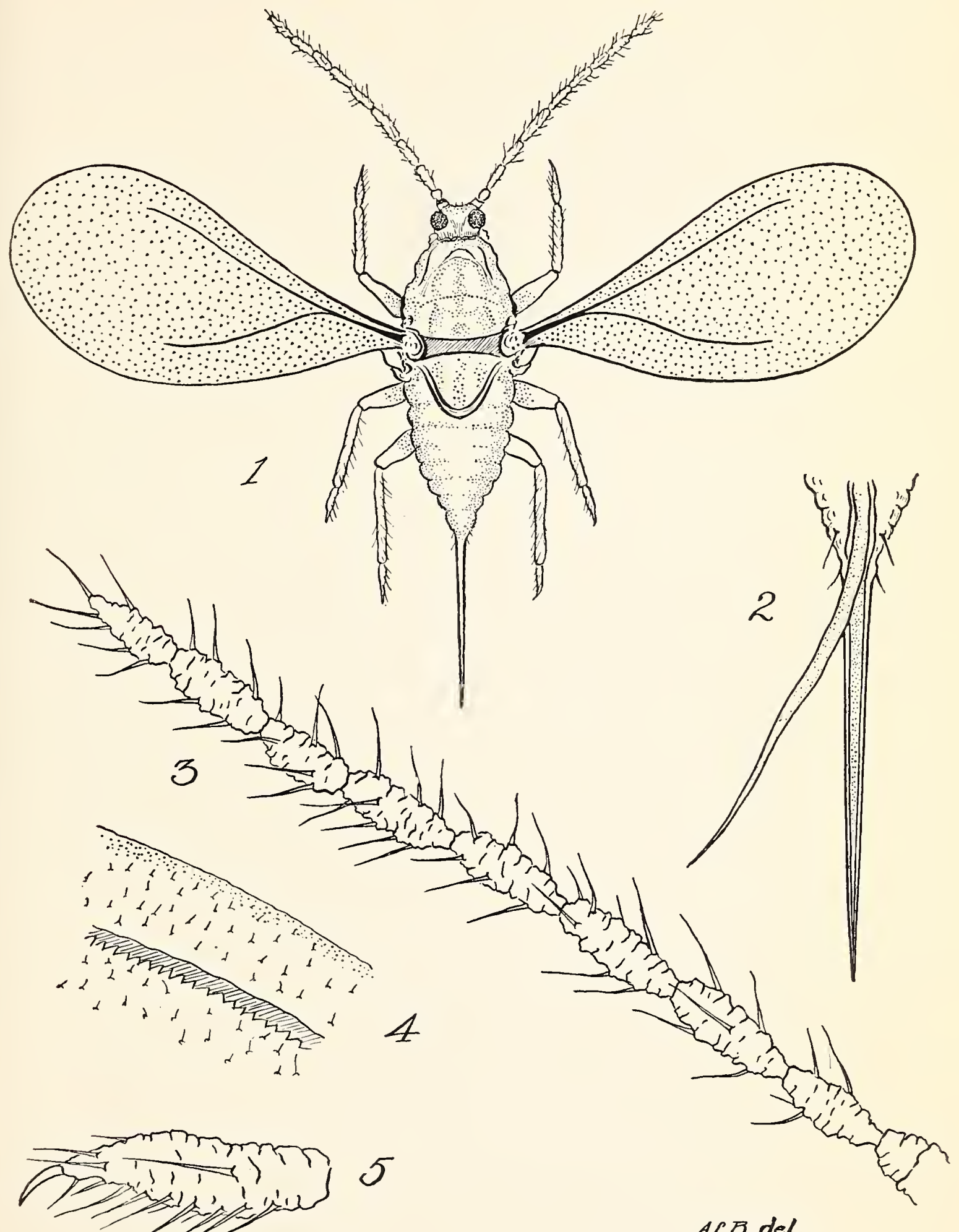

THE GRAPE SCALE.

Fig. 1.-Adult winged male. Fig. 2.-Genitalia of male. Fig. 3.-Antenna of male. Fig. 4.Serrations on costal vein. Fig. 5.-Tarsus and claw of maie. (Original.) 

in which it formed a new genius; it was later described as Prospaltella murtfeldtii How. More than a dozen of these little Hymenoptera emerged from the scales on a piece of grape cane about 5 inches long.

SPECIES REARED BY THE WRITER.

On May 20, 1911, the writer examined many female scales and found that about 80 per cent of the insects were parasitized. (See Pl. XVIII, fig. 2.) In some instances the parasites were found under

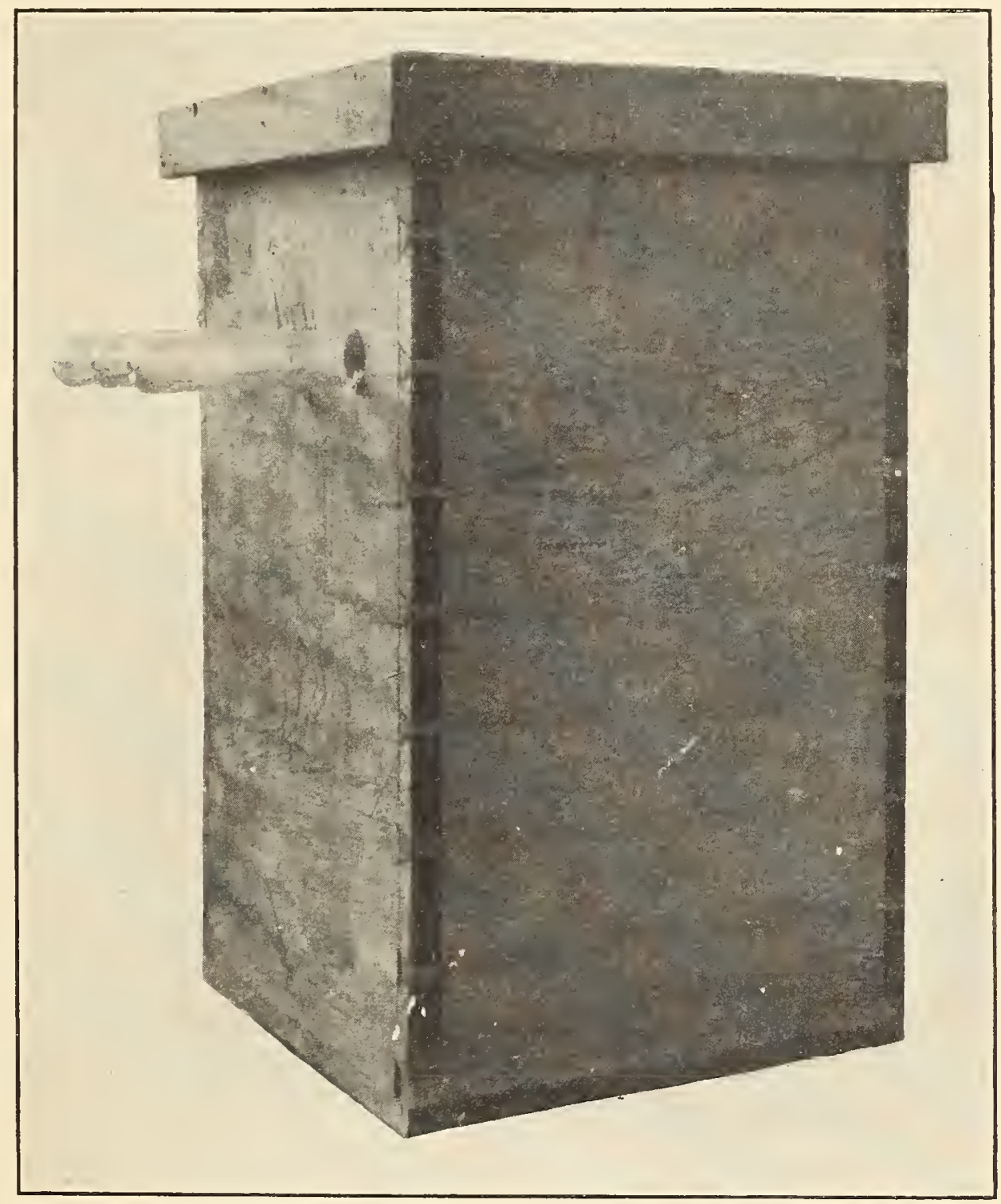

Fig. 27.--Cage used in rearing parasites of the grape scale. The parasites come to the light and are entrapped in the glass tubes. After model of the California state Board of Horticulture. (Original.)

the exuviæ, but generally the parasite had emerged, leaving an exit hole near the central upper part of the scale.

Many grape twigs were placed in a parasite rearing cage, shown in figure 27 , and as the parasites emerged they came to the light and were entrapped in the test tubes.

The following species of the parasites reared were determined by Dr. L. O. Howard: Ablerus clisiocampæ Ashm., Physcus varicornis How., Azotus marchati How., Coccophagus n. sp., Aphelinus fuscipennis How., Prospaltella murtfeldtii How., Ablerus n. sp., and Physcus sp. 
Mr. J. C. Crawford determined a parasite reared from this species as belonging to the family Ceraphronidæ, but on account of the crushed condition of the insect the species was unrecognizable.

Many of the parasites reared from this scale belonged to the family Encyrtidæ and were sent to Mr. A. A. Girault for determination; they all proved to be one species, Signiphora pulchra Girault MS.

The following is a complete list of the parasites reared by the writer from the grape scale: Ablerus clisiocampæ Ashm.; Ablerus n. sp., Physcus varicornis How., Physcus sp., Azotus marchali How., Coccophagus n. sp., Aphetinus fuscipennis How., Centrodora sp., Prospaltella murtfeldtii How., Signiphora pulchra Girault MS. The scale was also found infested with the predaceous mite Tyroglyphus sp.

\section{PREVENTIVES AND REMEDIES.}

LINE-SULPHUR WASH.

The lime-sulphur spray mixture is one of the most important insecticides used by the fruit grower in combating scale insects. It is prepared as follows:

\section{FORMULA.}

Stone lime........................................... 20

Sulphur (flowers or flour).......................... 15

Water to make.............................................. 50

First heat in a kettle or caldron about one-third the quantity of water required. When the water is hot, add all the lime and immediately add all the sulphur. The latter, however, should have been previously put through a fine-mesh sieve in order to eliminate the hard lumps, and hare been mixed into a stiff paste with water. When the lime has slaked, about another one-third of the water should be added and the cooking should continue for from 40 minutes to 1 hour; then the remainder of the water should be added. The solution should always be strained in order to eliminate the lumps and lessen the danger of clogging the nozzles.

\section{SELF-BOILED LME-SULPHUR WASH.}

The self-boiled lime-sulphur mixture is made by the heat generated in slaking the lime, and may be used for spraring infested vines in foliage.

FORMULA.

Stone lime................................. 8

Sulphur (flowers or flour).............................. 8

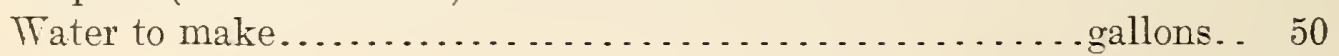

Place the lime in a 50-gallon barrel, add 2 or 3 gallons of cold water, then add the sulphur, which should hare been previously screened. Stir the mixture occasionally and add more water if the solution 
becomes too thick. As soon as the lime has completely slaked add cold water to make the 50 gallons. Strain the liquid before pouring it into the spray tank.

OTHER SPRAYS.

In addition to the lime-sulphur sprays other contact insecticides may be employed, as whale-oil-soap solution, kerosene or crude petroleum emulsion, etc. For winter treatment, however, probably nothing would be better than the strong lime-sulphur wash above mentioned. For some unexplained reason, sulphur sprays when used on grapes in foliage produce harmful effects in checking the growth of the foliage. When it is desired to treat the grape scale during the period of foliage of the vines, the use of whale-oil soap at the rate of 1 pound to 3 or 4 gallons of water, or of 10 to 12 per cent kerosene emulsion, may be advisable.

There are on the market certain proprietary sprays, known as miscible oils, and also concentrated lime-sulphur solutions. These have only to be diluted with water and are ready for use. Where but a small amount of spraying is to be done, their employment will often be found advantageous in preference to making washes at home.

WHEN TO SPRAY.

Summer spraying. - The larvæ appear in the vicinity of Washington, D. C., about the middle of May, and it is necessary to give the first application about one week after their first appearance. Of course south of this locality one would expect them to appear a few days earlier and north of it a few days later. Close examination has shown that the larvæ are constantly hatching and crawling over the plant during a period of about two months, each "louse" settling down, however, within about 48 hours. On May 5, 1910, some grapevines which were badly infested with this insect were sprayed with selfboiled lime-sulphur wash, only one application being made, and upon a later examination only a few living insects were found. On account of the habit of the young "lice" of settling under the shreds of dead bark it is very difficult to apply the liquid so that it will come into contact with all the insects. This makes it advisable to give a second and sometimes a third application.

Winter spraying.-As the foliage is very susceptible to burning, the stronger caustic sprays must be applied during the dormant period of the plants. The concentrated lime-sulphur wash and strong whaleoil soap wash, as well as strong kerosene emulsion, are used during this season of the year. As the winter is passed by the insects under the protective scale covering, an application, in order to be effective, must be very thoroughly made. 


\section{BIBLIOGRAPHY.}

1880. Сомsтock, J. H.-The grape scale. <Ann. Rept. U. S. Comm. Agr., pp. 309-310.

Characters of Coccidæ; metamorphoses; methods of preventing spread; useful products of scale insects, and a description of many new species, including Aspidiotus uvæ.

1883. Сомsтоск, J. H.-Scale insects. <2nd Rept. Dept. of Ent., Cornell Univ. Exp. Sta., p. 71.

Reported from Vevay, Ind., on grapevines; also on hickory from Florida.

1889. Murtfeldt, Miss M. E.-Entomological notes of the season of 1888 . <Ann. Rept. U. S. Dept. Agr. f. 1888, pp. 135, 136.

Short discussion of this species mentioning as parasites an Aphelinus parasite and the twicestabbed ladybird beetle.

1889. Murtfeldt, Miss M. E.-Parasites of Aspidiotus uvæ Comst. ～Ｉns. Life, vol. 2, p. 253.

Prospalta murtfeldtii How. reported as a parasite of the grape scale.

1890. Murtfeldt, Miss M. E.-Parasites of Aspidiotus uvæ Comst. <Ins. Life, vol. 3, p. 72.

Prospalta murtfeldtii reared from A spidiotus uvæ Comst.

1891. French, G. H.-The grape scale. <Prairie Farmer, February 14, p. 108. Popular note on this species.

1892. Cockerell, T. D. A.-List of Coccidæ observed in Jamaica. <Ins. Life, vol. 4, p. 333 .

Host plants given for many scale insects, including this species.

1892. Cockerell, T. D. A.-Coccidæ observed in Jamaica. <Journ. Inst. Jamaica, vol. 1, p. 142.

Additional species found in Jamaica, including Aspidiotus uvæ.

1893. Murtfeldt, Miss M. E.-Injurious insects of the season of 1893 . <36th Ann. Rept. Hort. Soc. Mo., pp. 118-119.

Notes on Ceresa bubalus, Loxostege macluræ, bagworm, apple-tree borers, A spidiotus uvæ, and Hæmatobia serrata [Lyperosia irritans].

1893. Cockerelu, T. D. A.-A list of West Indian Coccidæ. <Journ. Inst. Jamaica, vol. 1, No. 53, p. 255.

Listed among scales of Jamaica.

1894. Howard, L. O.-Two parasites of important scale insects. <Ins. Life, vol. 7, pp. 5-8.

Prospalta murtfeldtii $\mathrm{n}$. gen. and n. sp., parasite of the grape scale.

1894. Cockerell, T. D. A.-A check list of the Coccidæ of the Neotropical Region. <Trinidad Field Nat. Club, vol. 1, no. 12, p. 312.

List ô species and their distribution.

1894. Riley, C. V.-Department of Physiology and Entomology. Important insects of the year. <7th Rept. Md. Agr. Exp. Sta., pp. 190-191.

Reported as doing damage to grape in Maryland.

1894. HowARD, L. O.-Resin wash against the grape Aspidiotus. ' CIns. Life, vol. 7, p. 53 .

A remedy for seale insects.

1895. Cockerell, T. D. A.-Scale insects liable to be introduced into the United States. <Garden and Forest, vol. 8, p. 513.

Popular discussion of this and other species of scale insects, stating danger of introducing new pests.

1897. Webster, F. M.-Scale insects, their habits and distribution, with means of holding them in check. <Ind. Hort. Rept. for 1896, p. 47.

Aspidiotus uvæ bears an indistinct resemblance to San Jose scale. Reported many times in the last 10 years. 
1896. Cockerell, T. D. A.-Check list of Coccidæ. <Bul. Ill. St. Lab. Nat. Hist., vol. 4, p. 332 .

Merely gives list of seale insects. No descriptions.

1896. Cockerell, T. D. A.-Nearctic Coccidæ. <Can. Ent., vol. 26, no. 2, p. 32.

List of Nearctic scale insects.

1896. Johnson, W. G.-Notes on new and old scale insects. <Bul. 6, Div. Ent., U. S. Dept. Agr., p. 76.

A spidiotus comstocki Johnson, closely related to A spidiotus uvæ Comst.

1897. Cockerell, T. D. A.--Annotated list of the species of Aspidiotus. <Bul. 6,

n. s., Bur. Ent., U. S. Dept. Agr., p. 22.

Very brief description, giving host plants and distribution.

1898. Hunter, S. J.-Coccidæ of Kansas. <Contr. Kans. Ent. Lab., no. 64, p. 4. Food plants and bibliography.

1898. Chambliss, C. E.-Scale insects, San Jose and other species. <Bul. 4, Tenn. Exp. Sta., p. 149, pl., fig. 1.

Treats of $A$. perniciosus, A . uvæ, Diaspis rosæ, Pulvinaria innumerabilis, Lccanium nigrofasciatum, Chionaspis furfurus, and other seale insects.

1898. Leonardi, L.--Monografia del genere Aspidiotus Bouché. <Riv. Pat. Veg., vol. 6, p. 218.

Short scientific description of the female insect, giving habitat, host plants, and figure of pygidium.

1898. Parrott, P. J.-Some scales of the orchard. <Trans. Kans. St. Hort. Soc., vol. 23, p. 108.

Notes on various species of scale insects.

1899. Newell, W.- On the North American species of the subgenera Diaspidiotus and Hemiberlesia, of the Genus Aspidiotus. <Contr. Dept. Zool. \& Ent. Iowa State Agr. College, No. III, p. 12.

Brief description, distribution, and host plants.

1900. Scotт, W. M.-Notes on Coccidæ of Georgia. <Bul. 26, n. s., Div. Ent., U. S. Dept. Agr., p. 50.

Short note, giving occurrence on sycamore in Georgia.

1901. Felt, E. P.-Grapevine Aspidiotus. <Country Gentleman, April 4, pp. 278-279.

Popular account of the insect.

1901. Forbes, S. A.--Principal nursery pests likely to be distributed in trade $<$ Cir. 36, Ill. Agr. Exp. Sta., p. 24.

Note, giving occurrence, remedies, etc. Figure.

1902. Banks, N.--Principal insects liab e to be distributed on nursery stock. <Bul. 34, n. s., Div. Ent., U. S. Dept. Agr., p. 20.

Brief account of several species of scale insects.

1902. Murtfeldt, Miss M. E.-Recent experiments with destructive insects, $<45$ th Rept. Mo. St. Hort. Soc., pp. 253-258.

Mentions "Comstock's grape scale"-probably this species.

1903. Fernald, Mrs. M. E.-Catalogue of the Coccidæ of the world. <Bul. 88, Mass. Agr. College, p. 280.

Host plants and distribution.

1903. Forbes, S. A.-Classification and description of the insects and fungus pests of the nursery most important to the nursery trade. <22d Rept. State Ent. Ill., p. 120.

Brief note of its occurrence, suggesting the use of whale-oil soap and kerosene emulsion as remedies. Figure.

1904. Sanders, J. G.-Coccidæ of Ohio. <Ohio State Univ., Contr. Dept. Zool. \& Ent., no. 18, pp. 68-69.

Brief description, host plants, and distribution. 
1904. Trtus, E. S. G., and Pratt, F. C.-Catalogue of the Exhibit of Economic Entomology at the Louisiana Purchase Exposition. <Bul. 47, n. s., Div. Ent., U. S. Dept. Agr., pp. 16, 38. List of food plants.

1908. TAYLoR, E. P.-Insects of the orchard of Missouri. <Bul. 18, Mo. St. Fruit Exp. Sta., pp. 72-73, fig. 20. Occurrence, effect on the vine, remedies.

1909. Sмгтн, J. B.-Ann. Rept. N. J. St. Mus., p. 129. Found on grape at Egg Harbor, N. J. 


\section{N D EX.}

Ablerus clisiocampæ, parasite of Aspidiotus (Diaspidiotus) uvæ . . . . . . . . 119, 120

n. sp., parasite of Aspidiotus (Diaspidiotus) uvæ . . . . . . . . . . . 119, 120

Egeria opalescens $=$ Sanninoidea opalescens ..................... 66

original description . . . . . . . . . . . . . 78

Agropyron repens, food plant of Tarsonemus culmicolus . . . . . . . . . . . . . . 112

Almond root stocks, relative susceptibility to Sanninoidea opalescens . . . . . . 68

Ampelopsis sp., food plant of Aspidiotus (Diaspidiotus) uvæ . . . . . . . . . . 116

Ant, enemy of Sanninoidea opalescens . . . . . . . . . . . . . . . . . . . 83

Aphelinus fuscipennis, parasite of Aspidiotus (Diaspidiotus) uvæ . . . . . . . 119, 120

parasite of Aspidiotus uvæ, bibliographic reference . . . . . . . . . . 122

Aphis prunicola, the black peach aphis . . . . . . . . . . . . . . . . . . . . . . 104

Apple, food plant of codling moth......................... 13-32

nursery stock, injury by Tarsonemus waitei................ 108

root stock, relative susceptibility to Sanninoidea opalescens.......... 68

tree borers, bibliographic reference . . . . . . . . . . . . . . . . . . . . . 122

Apricot, food plant of Sanninoidea opalescens . . . . . . . . . . . . . . . . 67-68

root stocks, relative succeptibility to Sanninoidea opalescens....... 68

Arsenate of lead against codling moth . . . . . . . . . . . . . . . . . 42, 51

and Bordeaux mixture against rose-chafer in vineyards. . . . . 59-64

self-boiled lime-sulphur wash against peach and plum slug. 102

Bordeaux mixture, and molasses against rose-chafer... . 59, 60, 62-63

Arsenicals against rose-chafer in vineyards. . . . . . . . . . . . . . . . . . . 58-63

sweetened, against rose-chafer in vineyards . . . . . . . . . . . . 62-63

Arsenite of lime and molasses against rose-chafer in vineyards............ 62

Bordeaux mixture, and molasses against rose-chafer in vine-

yards . . . . . . . . . . . . . 62

injury to grapevines by heavy applications........... $\quad 59$

Aspidiotus comstocki, bibliographic reference...................... 123

perniciosus, bibliographic reference ..................... 123

the San Jose scale . . . . . . . . . . . . . . . . . . . . . . 116

(Diaspidiotus) uvæ, adult female, description . . . . . . . . . . . . 117-118

winged male, description ........... 118

bibliography........................ 122-124

description . . . . . . . . . . . . . . . . . . 117-118

distribution . . . . . . . . . . . . . . . . . . . . 115-116

food plants. . . . . . . . . . . . . . . . . 115-116

habits. . . . . . . . . . . . . . . . . . . . 116-117

natural history . . . . . . . . . . . . . . . . . . . . 116-117

parasites . . . . . . . . . . . . . . . . . . 118-120

preventives...................... 120-121

remedies . . . . . . . . . . . . . . . . . . . . . . . 120-121

scale of female, description . . . . . . . . . . 117

male, description . . . . . . . . . . . . 117

"Avoines en cigares" injury to oats caused by Tarsonemus spirifex.......... 111

Azotus marchali, parasite of Aspidiotus (Diaspidiotus) uvæ . . . . . . . . . . . 119-120 


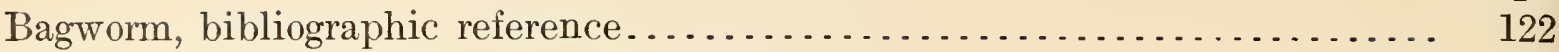

Barley, food plant of Tarsonemus spirifex............................ 111

"Bianchella" malady to rice produced by Tarsonemus oryzæ............... 111

Bisulphid of carbon treatment against California peach borer.............. 87

Black-rot fungus of grapevines, control by Bordeaux mixture............... 62

Bordeaux mixture and arsenate of lead against rose-chafer in vineyards . . . . . . 59-64 arsenate of lead, and molasses against rose-chafer in vineyards............................... 59, $60,62-63$ arsenite of lime, and molasses against rose-chafer in vine-

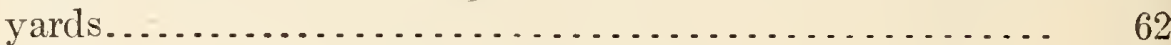

in control of black-rot fungus of grapevine... . . . . . . . . . . 62

Cage for rearing Caliroa (Eriocampoides) amygdalina................... . . 93-94

Caliroa (Eriocampoides) amygdalina, adult, life history ................... 94-95

damage, extent................... 100

developmental period, total............ $\quad 100$

egg, life history .................. 96

injury to peach and plum trees........ 91, 100

larva, life history ................... . . 96-98

life history ................... . 94-100

natural enemies...... . . . . . . . . . . . . 100-102

observations thereon in $1910 \ldots \ldots . . . . . . .992-94$

oviposition....................... . 94-95

prepupa, life history .................. . . 98-99

pupa, life history................... 99

remedies............................ 102

(Selandria) obsoletum, name used for Caliroa (Eriocampoides) amygdalina. $\quad 91$

Carabid larvæ, enemies of codling moth.......................... 32

Carpocapsa pomonella. (See Codling moth.)

Carya alba, food plant of Aspidiotus (Diaspidiotus) uvæ.................. 116

sp., food plant of Aspidiotus (Diaspidiotus) uvæ.................... 116

Cement, hydraulic, ineffective against California peach borer . . . . . . . . . . . 87

Centrodora sp., parasite of Aspidiotus (Diaspidiotus) uvæ................. 118-120

Cerasus demissa, native food plant of Sanninoidea opalescens................ $\quad 67$

Ceresa bubalus, bibliographic reference............................ $\quad 122$

Cherry, food plant of Sanninoidea opalescens ..................... 67,68

root stocks, relative suscepibility to Sanninoidea opalescens.......... 68

Chionaspis furfurus, bibliographic reference....................... 123

Chokecherry, western. (See Cerasus demissa.)

Chrysanthemum, food plant of Tarsonemus pallidus...................... 112

Coal tar, lime, and whale-oil soap against California peach borer............. $\quad 87$

Coccophagus n. sp., parasite of Aspidiotus (Diaspidiotus) uvæ............... . 119, 120

Codling moth in California... . . . . . . . . . . . . . . . . . . . . . . . . . . 13-51

band records for 1909 and $1910 \ldots \ldots . . . \ldots \ldots . . .27-31$

control on pears.......................... . . 32-51

commercial results from spraying. . 41-51

Contra Costa County, 1909 . . . . . . 41-44

$1910 \ldots . . .44-49$

effect of sprays on places of en-

trance by larvæ............. . 33-41

profits from spraying......... 43-44, 49

Solano County, 1910........... . 49-51

eggs, first brood........................ 18-21

second brood....................... 24 
Conge.

$19-20$

time of oviposition. . . . . . . . . . . 18-19

arvæ, development in fruit......... 20-21

larval life in cocoon.......... 21

time of hatching. ........... 20

moths...................... . 23-24

pupæ, length of period. . . . . . . . . . 21-23

time of pupation........... 21

generation. . . . . . . . . . . . . . . . . . . . . . 18-24

larvæ, first brood . . . . . . . . . . . . . . . . . . . . . . 20-21

overwintering....................... . . 14

second brood...................... 25-26

life cycle of first generation............... . 24

history notes. . . . . . . . . . . . . . . . . . . . . 14-32

review for 1909 and $1910 \ldots . . . . . . .26$. 26-31

moths, first brood............. . . . . . . . . 23-24

spring brood . . . . . . . . . . . . . . . . . 17-18

natural enemies............ . . . . . . . . . . . . . 32

overwintering larvæ.................... 14

parasites............................... 32

predaceous enemies......... . . . . . . . . . . . . . 32

pupæ, first brood. . . . . . . . . . . . . . . . . . . . 21-23

spring brood . . . . . . . . . . . . . . . 14-16

recommendations for control . . . . . . . . . . . . . . 51

second brood eggs, incubation period ............. . 24

time of oviposition.......... 24

larvæ, development in relation to fruit 25

life in fruit............ . 25-26

overwintering. . . . . . . . . . 26

time of hatching........... 25

generation...................... 24-26

spring brood of moths................... . . . 17-18

pupæ...................... . 14-16

length of period.......... 15-16

summary................................. 51

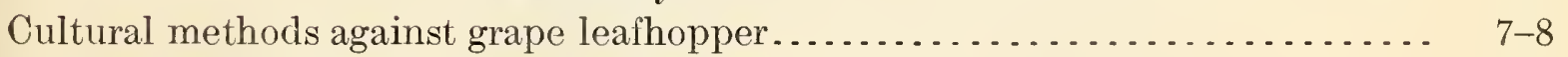

rose-chafer.................................... 64

Cushman, R. A., paper, "Notes on the Peach and Plum Slug (Caliroa [Eriocampoides] amygdalina)" ...... . . . . . . . . . . . . . . . . . . . . . . . . . . . . . 91-102

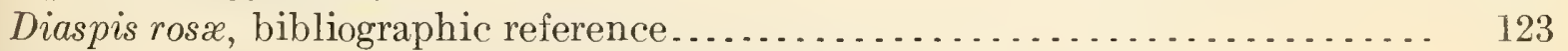

Dipterous larva, enemy of Sanninoidea opalescens...................... 83

Eriocampoides limacina, the pear slug, resemblance of larva of Caliroa (Eriocampoides) amygdalina thereto ..................................... 91

Eulabis rufipes, enemy of codling moth........................ $\quad 32$

Euthrips tritici (see also Thrips tritici).

in tender growing tips of peach and other vegetation . . . . . . 108

Festuca rubra, food plant of Tarsonemus culmicolus...................... . 112

Fidia viticida. (See Grape rootworm.)

Foster, S. W., paper, "Life History of the Codling Moth and its Control on Pears in California" . . . . . . . . . . . . . . . . . . . . . . . . . . . . . 13-51

"Fruitlet core rot" of pineapples, dissemination by Tarsonemus ananas. . . . . 112

Fungous diseases of grape, control by spraying . . . . . . . . . . . . . . . 63 
Glue and Paris green washes ineffective against California peach borer, injurious to trees. . . . . . . . . . . . . . . . . . . . . . . . . . . . . . . . . .

"Gophers," injury to root stocks of fruit trees in California............. . . 68

Grape (see also Vitis).

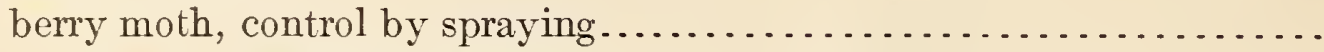

European. (See Vitis vinifera.)

food plant of Aspidiotus (Diaspidiotus) uvæ.................... . 115-124

grape leafhopper (Typhlocyba comes)................. 1-12

rose-chafer (Macrodactylus subspinosus) ............... . . 53-64

leafhopper. (See Leafhopper, grape.)

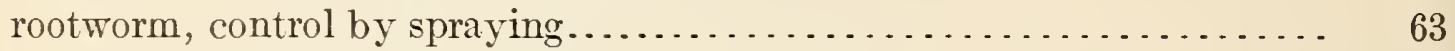

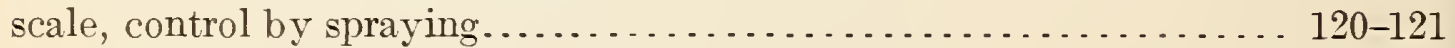

spraying in summer............................... 121

winter.......................................... 121

Grapes, wild. (See Vitis spp.)

Grasses, food plats of Tarsonemus culmicolus................ . . . . . . . 112

perhaps food plants of Tarsonemus spirifex.................... . 111

silver-top disease caused by Tarsonemus culmicolus.............. 112

Hæmatobia serrata, bibliographic reference... . . . . . . . . . . . . . . . . . 122

=Lyperosia irritans........................ 122

Handpicking rose-chafer beetles in vineyards....................... . . 57-58

Hyperallus calirox, parasite of Caliroa (Eriocampoides) amygdalina... . . . . . 101-102

Johnson, Fred, paper, "Spraying Experiments Against the Grape Leafhopper

in the Lake Erie Valley"................. 1-12

"Vineyard Spraying Experiments Against the Rosechafer in the Lake Erie Valley" ................. . 53-64

Kerosene (see also Petroleum and Oil).

emulsion against grape scale......................... 121

peach bud mite......................... 114

Ladybird, twice-stabbed, enemy of Aspidiotus uvæ, bibliographic reference.... 122

Leafhopper, grape, adult, life history ......................... $\quad 6-7$

adults, emergence in spring................... 4-5

not effectively controlled by sprays............ 8

characteristics............................. 2-3

control by spray applications against nymphs.......... 8-12

cost of spray application in the Lake Erie Valley........ 10-11

egg stage, life history............................ 5

emergence of adults in spring.................... 4-5

habits................................... $2-3$

hibernation................................... $3-4$

injuries in the Lake Erie Valley.................. 1-2

in the Lake Erie Valley, conclusion.................. 12

spraying experiments........... . 1-12

life history................................. $3-7$

nymphal stages, life history....................... 6

nymphs, control by spray applications............. $8-12$

remedial measures............................. $7-12$

Lecanium nigrofasciatum, bibliographic reference... . . . . . . . . . . . . . 123

Lime, coal tar, and whale-oil soap against California peach borer........... 87

crude oil wash against California peach borer.................. 86

oil mixture as preventive against California peach borer. ........ . . . . 83-85

sulphur salt mixture against California peach borer.............. 86

wash against grape scale...................... 120, 121 
Lime-sulphur wash against peach bud mite. . . . . . . . . . . . . 113, 114

concentrated, against grape scale............... 121

self-boiled, against grape scale.............. 120-121

and arsenate of lead against peach and plum

slug. . . . . . . . . . . . . . . . . . . . . 102

London purple, injury to grapevines by heavy applications. . . . . . . . . . . 59

Loxostege maclurx, bibliographic reference. . . . . . . . . . . . . . . . . . . . . . 122

Lygus pratensis, injury to peach nursery stock attributed thereto . . . . . . . . 105

Lyperosia irritans, bibliographic reference..................... 122

Macrodactylus subspinosus. (See Rose-chafer.)

Mango, food plant of Tarsonemus latus . . . . . . . . . . . . . . . . . . . . . . 112

injury by Tarsonemus latus........................... 112

Mite enemy of Sanninoidea opalescens. . . . . . . . . . . . . . . . . . . . 83

peach bud. (See Tarsonemus waitei.)

Molasses and arsenite of lime against rose-chafer in vineyards. . . . . . . . . .

arsenate of lead, and Bordeaux mixture against rose-chafer in vineyards................................... 59, 60,62-63

Bordeaux mixture and arsenite of lime against rose-chafer in vine-

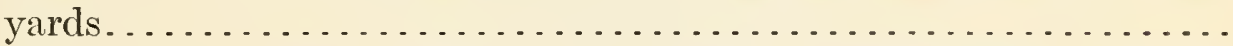

Moulton, Dudley, paper, "The California Peach Borer (Sanninoidea opalescens Hy. Edw.)" .................................... . 65-89

"Mounding" possibly not so effective against California peach borer as against

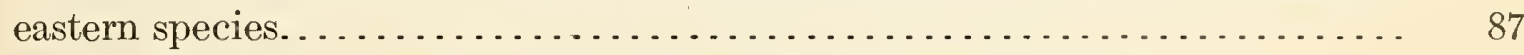

Oats, "avoines en cigares" affection caused by Tarsonemus waitei......... 111

food plant of Tarsonemus spirifex.......................... 111

Oil (see also Kerosene and Petroleum).

and lime mixture as preventive against California peach borer . . . . . . . 83-85

crude, and lime against California peach borer . . . . . . . . . . . . . 86

as preventive against California peach borer. . . . . . . . . . . . . 84-85

miscible, against grape scale. . . . . . . . . . . . . . . . . . . . 121

peach bud mite........................ 113

Paints and rosin ineffective against California peach borer, injurious to trees... $\quad 87$

Paris green, injury to grapevines by heavy applications. . . . . . . . . . . . 59

Peach and plum sawfly. (See Caliroa [Eriocampoides] amygdalina.)

slug. (See Caliroa [Eriocampoides] amygdalina.)

aphis, black. (See Aphis prunicola.)

borer. (See Sanninoidea exitiosa.)

California. (See Sanninoidea opalescens.)

bud mite. (See Tarsonemus waitei.)

food plant of Aphis prunicola . . .......................... 104

Caliroa (Eriocampoides) amygdalina . . . . . . . . . . 91-102

Euthrips tritici.......................... 108

Phyllocoptes cornutus........................ 104

Sanninoidea exitiosa....................... 65-66

opalescens . . . . . . . . . . . . . . . . 65-89

Tarsonemus waitei............................ . 103-114

reported food plant of Lygus pratensi . . . . . . . . . . . . . . . . . . 105

Thrips tritici. . . . . . . . . . . . . . . . . . 105

root stocks, relative susceptibility to Sanninoidea opalescens........ 68

"stop-back" disease the work of Tarsonemus waitei............. 107

thrips. (See Thrips tritici.)

Pear, calyx lobes with reference to spraying against codling moth . . . . . . . 32-33

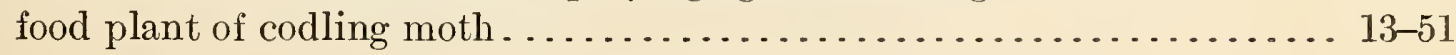


Pẹar slug. (See Eriocampoides limacina.)

Page.

Petroleum. (See also Kerosene and Oil.)

emulsion, crude, against grape scale

121

Phleum pratense, food plant of Tarsonemus culmicolus...................

Phyllocoptes cornutus, confusion with Tarsonemus waitei.

injury to peach leaves. . . . . . . . . . . . . . . . . . . . . 104

Physcus sp., parasite of Aspidiotus (Diaspidiotus) uvæ........... . . . . . 119, 120

varicornis, parasite of Aspidiotus (Diaspidiotus) uvæ............. 119, 120

Pineapple disease, "fruitlet core rot," dissemination by Tarsonemus ananss... 112

food plant of Tarsonemus ananas ......................... 112

Platanus occidentalis, food plant of Aspidiotus (Diaspidiotus) uvæ . . . . . . . . 11.6

sp., food plant of Aspidiotus (Diaspidiotus) uvæ............... 116

Plum and peach sawfly. (See Caliroa [Eriocampoides] amygdalina.)

slug. (See Caliroa [Eriocampoides] amygdalina.)

food plant of Caliroa (Eriocampoides) amygdalina . . . . . . . . . . . . . . 91-102

Sanninoidea opalescens..................... 67, 68

root stocks, native, relative susceptibility to Sanninoidea opalescens.... $\quad 68$

wild, Myrobalan, or cherry. (See Prunus cerasifera.)

Polychrosis viteana. (See Grape-berry moth.)

Prospalta murtefeldtii, bibliographic references...... . . . . . . . . . . . . . . . 122

Prospaltella murtfeldtii, parasite of Asipidiotus (Diaspidiotus) uvæ........ 119, 120

Pruning against peach bud mite. . . . . . . . . . . . . . . . . . . . . . . . . . . 113-114

Prunus cerasifera root stocks almost exempt from injury by Sanninoidea opales-

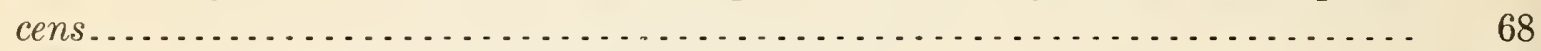

Pulvinaria innumerabilis, bibliographic reference... . . . . . . . . . . . . . 123

Quaintance, A. L., paper, "Notes on the Peach Bud Mite, an Enemy of Peach

Nursery Stock (Tarsonemus waitei Banks, MSS)" ... . . . . . . . . . . . . . . 103-114

Rearing Caliroa (Eriocampoides) amygdalina, cage.... . . . . . . . . . . . . . . . 93-94

Rice, "bianchella" malady produced by Tarsonemus oryzæ. . . . . . . . . . . . 111

food plant of Tarsonemus oryzæ............................ 111

Rose bug, colloquial name for rose-chafer (Macrodactylus subspinosus) . . . . . . 56

chafer difficulties in control................................... 53

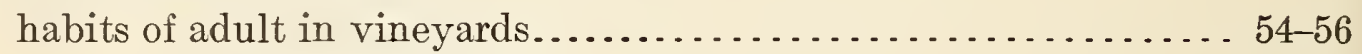

larva in vineyards........................ $56-57$

in Lake Erie Valley, injury to vineyards. . . . . . . . . . . . . 53

time to make spray applications in vineyards. $63-64$

vineyard spraying experiments against it... 53-64

vineyards, control by arsenicals.................... 58-64

cleaning up breeding places......... 64

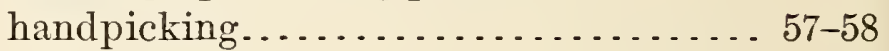

summary................................ 64

oviposition.................................... 56

remedial measures in vineyards ..... . . . . . . . . . . . . . . . . 57-64

Rosin and paints ineffective against California peach borer, injurious to trees.. $\quad 87$

Rye, food plant of Tarsonemus spirifex........................... . 111

Sanninoidea exitiosa, comparison with Sanninoidea opalescens.......... . 65-66,78

the peach borer of the Eastern United States. . . . . . . . . 65-66

opalescens, adult............................... $77-82$

description, original, and subsequent notes..... 78

bibliography . . . . . . . . . . . . . . . . . . . . . . . . . . . 88-89

broods, number, as shown by "worming" recorc's..... 71-73

cocoon, formation, position, and structure... . . . . . . 74-75

comparison with Sanninoidea exitiosa . . . . . . . . . 65-66, 78 
Page.

Sanninoidea opalescens, control methods........................... 83-88

distribution . . . . . . . . . . . . . . . . . . . . . . 66-68

egg, description............................. $\quad 68$

development and hatching. . . . . . . . . . . . 68-69

fertility ............................... 69

feeding habits of larvæ................ $69-71,74$

of moths............................. 80

flight................................... 80

food plants, native......................... 67

fruit budding and grafting stocks resistant to attack.... 68

history in relation to fruit growing in Santa Clara Valley. $\quad 67$

in California, limits of areas in which injury occurs... 67-68

Santa Clara Valley, history .................. 67

injury, character............................ 71

to peach orchards in Santa Clara Valley ...... 65

larva, character of injury . . . . . . . . . . . . . . . . . $\quad 71$

feeding habits within burrow............... . $\quad 74$

newly hatched, feeding habits. . . . . . . . . . . 69-70

period when entering trees.................. 71

larval period, length, as shown by "worming" records. 71-73

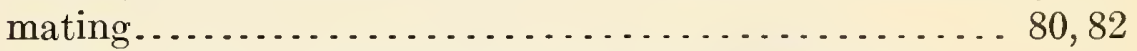

moths, earliest, maximum, and latest appearances.... $\quad 79$

habits of those newly emerged ............. $\quad 77-78$

length of life......................... $\quad 82$

natural enemies.............................. 83

oviposition........................... . 80-82

preventives, experiments therewith . . . . . . . . . . . . . 83-85

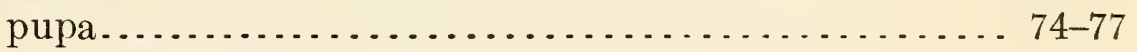

description .............................. $\quad 75$

length of period...................... . . $75-77$

pupæ, earliest, maximum, and latest appearance..... $\quad 77$

recommendations for control................... 88

remedies against eastern peach borer not effective.... $\quad 87$

soil conditions as bearing on infestation............ 68

summary ................................. 88

varieties of cultivated fruits attacked.............. 68

ẃashes as protection after "worming," formulas. . . . . . 86-87

"worming" and applying washes in control.... . . . . 85-87

records......................... $71-73$

pacifica $=$ Sanninoidea opalescens............................. 66

Sasscer, E. R., description of Aspidiotus (Diaspidiotus) uvæ............... 117-118

Sawfly, peach and plum. (See Caliroa [Eriocampoides] amygdalina.)

Scale, grape. (See Aspidiotus [Diaspidiotus] uvæ.)

San Jose. (See Aspidiotus perniciosus.)

"Set-back" of peach. (See "Stop-back.")

Signiphora pulchra, parasite of Aspidiotus (Diaspidiotus) uvæ.............. 120

Silver-top disease of grasses caused by Tarsonemus culmicolus................ $\quad 112$

Slug, peach and plum. (See Caliroa [Eriocampoides] amygdalina.)

pear. (See Eriocampoides limacina.)

Soap solution, whale-oil, against grape scale....................... . 121

peach bud mite.................... 114

coal tar, and lime against California peach borer.... $\quad 87$ 
Stiretrus anchorago, enemy of Caliroa (Eriocampoides) amygdalina............. pulchella $=$ Stiretrus anchorago . ........................... 100

"Stop-back" disease of peach, the work of Tarsonemus waitei. . . . . . . . . . 107

Sugar cane, food plant of Tarsonemus bancrofti and another species of Tarsone-

mus ....................................... 112

injury by Tarsonemus bancrofti and another species of Tarsonemus. $\quad 112$

Tarsonemus ananas, injury to pineapples....................... 112

bancrofti, injury to sugar cane....................... 112

culmicolus, injury to grasses . . . . . . . . . . . . . . . . . . . . 112

latus, injury to mango . . . . . . . . . . . . . . . . . . . . . . . 112

oryzæ, injury to rice ................................. 111

pallidus on chrysanthemum ........................ 112

sp., injury to sugar cane ............................ 112

spirifex, injury to oats, wheat, barley, and rye............. 111.

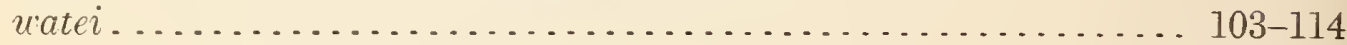

economic importance .......................... 106-110

habits.................................... 110

history . . . . . . . . . . . . . . . . . . . . . . . . . 103-106

injury to peach, nature........................ $109-110$

natural history ............................... . 110

relationship, systematic, and other species............ 111-112

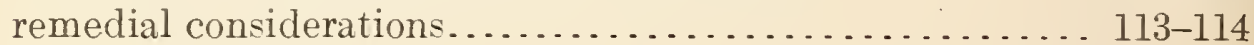

Thrips tritci (see also Euthrips tritici).

injury to peach attributed thereto..................... 105

Tobacco extract, blackleaf, against grape leafhopper................. $8-12$

"40," against grape leafhopper.............. . . 9

Trichogramma minutum, parasite of Caliroa (Eriocampoides) amygdalina...... 100-101

Typhlocyba comes. (See Leafhopper, grape.)

var. coloradensis, adult, figure .................. . 1

Tyroglyphus sp., parasite of Aspidiotus (Diaspidiotus) uvæ............... 118, 120

Vitis (see also Grape).

spp., food plants of Aspidiotus (Diaspidiotus) uvæ ............... $\quad 116$

vinifera, food plant of Aspidiotus (Diaspidiotus) uvæ ............. 116

Wheat, food plant of Tarsonemus spirifex. ...................... 111

"Worming" and applying washes against California peach borer........... . 85-87

records for California peach borer . .................... $71-73$

Trappings of paper, etc., not successfully used against California peach borer. . $\quad 87$

Zimmer, James F., paper, "The Grape Scale (Aspidiotus [Diaspidiotus] uvæ Comst.)". .......................................... 115-124

ADITIONAL COPIES of this publication A may be procured from the SUPERINTENDENT OF DocuMENTS, Government Printing Office, Washington, D. C., at 25 cents per copy

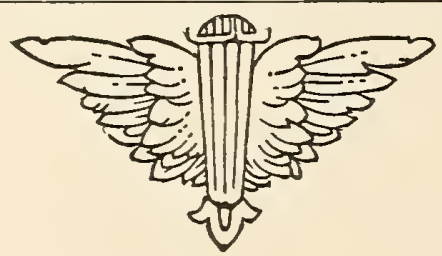

